\title{
Life Cycle Assessment of a Biomass Gasification Combined-Cycle System
}

M.K. Mann and P.L. Spath

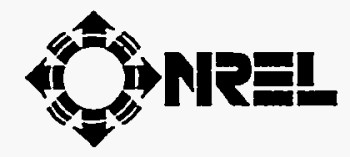

National Renewable Energy Laboratory 1617 Cole Boulevard Golden, Colorado 80401-3393

A national laboratory of the U.S. Department of Energy Operated by Midwest Research Institute for the U.S. Department of Energy Under Contract No. DE-AC02-83CH10093

Prepared under Task No. BP811030

December 1997 . 
This publication was reproduced from the best available camera-ready copy subminted by the subcontractor and received no editorial review at NREL.

\section{NOTICE}

This report was prepared as an account of work sponsored by an agency of the United States government. Neither the United States government nor any agency thereof, nor any of their employees. makes any warranty, express or implied, or assumes any legal liability or responsibility for the accuracy, completeness, or usefulness of any information, apparatus, product, or process disclosed, or represents that its use would not infringe privately owned rights. Reference herein to any specific commercial product, process, or service by trade name, trademark, manufacturer, or otherwise does not necessarily constitute or imply its endorsement, recommendation, or favoring by the United States govemment or any agency thereof. The views and opinions of authors expressed herein do not necessarily state or reflect those of the United States government or any agency thereof.

Available to DOE and DOE contractors from:

Office of Scientific and Technical Information (OSTI)

P.O. Box 62

Oak Ridge, TN 37831

Prices available by calling (423) 576-8401

Available to the public from:

National Technical Information Service (NTIS)

U.S. Department of Commerce

5285 Port Royal Road

Springfield, VA 22161

(703) 487-4650 


\section{DISCLAIMER}

Portions of this document may be illegible electronic image products. Images are produced from the best available original document. 


\title{
Life Cycle Assessment of a Biomass Gasification Combined-Cycle Power System
}

\author{
Margaret K. Mann \\ Pamela L. Spath
}

December, 1997

NOTICE: This report was prepared as an account of work sponsored by an agency of the United States government. Neither the United States government nor any agency thereof, nor any of their employees, makes any warranty, express or implied, or assumes any legal responsibility for the accuracy, completeness or usefulness of any information, apparatus, product or process disclosed, or represents that its use would not infringe on privately owned rights. Reference herein to any specific commercial product, process, or service by trade name, trademark, manufacturer, or elsewise does not necessarily constitute or imply its endorsement, recommendation, or favoring by the United States government or any agency thereof. The views and opinions of authors expressed herein do not necessarily state or reflect those of the United States government or any agency thereof.

This article is offered by Midwest Research Institute (MRI) employees under U.S. Government Contract No. DE-AC36-83CH10093. The Government and MRI retain non-exclusive, royalty-free license to publish or reproduce published articles, or allow others to do so for Government purposes. 


\section{EXECUTIVE SUMMARY}

Electric power production from biomass has the potential to make significant contributions to the power mix in the United States, and to do so with substantially fewer environmental impacts than current technologies. Using dedicated energy crops for power production will significantly close the carbon cycle, reduce and stabilize feedstock costs, increase the feasible size of biomass power plants, and provide economic benefits to agricultural communities. However, to realize these potential contributions, biomass power systems must be competitive on a cost and efficiency basis. Additionally, a complete picture of how the biomass facility will affect the environment is needed. This requires an analysis of the entire system from biomass crops through power production.

A life cycle assessment (LCA) on the production of electricity from biomass in a combined cycle system based on the Battelle/FERCO gasifier has been performed. Twenty air, twenty-five water, and seven solid emissions, plus seventeen natural resources and six types of energy were quantified for the system. In keeping with the cradle-to-grave concept of LCA, the energy and material flows of all processes necessary to operate the power plant are included in the assessment. The overall system consists of the production of biomass as a dedicated feedstock crop, its transportation to the power plant, and electricity generation. Upstream processes required for the operation of these sections are also included. Particular attention was paid to studying the net system $\mathrm{CO}_{2}$ emissions and energy production. Finally, a sensitivity analysis on the results was performed.

LCA is a systematic analytical method to identify, evaluate, and help minimize the environmental impacts of a specific process or competing processes. Material and energy balances are used to quantify the emissions, resource depletion, and energy consumption of all processes between transformation of raw materials into useful products and the final disposal of all products and byproducts. The results are then used to evaluate the environmental impacts of the process so that efforts can be focused on mitigating possible effects. Additionally, to better understand the total environmental and economic aspects of this process, a previous technoeconomic analysis was updated to reflect design changes that may reduce certain emissions.

The primary purpose of conducting this life cycle assessment was to answer many of the questions that are repeatedly raised about biomass power in regards to $\mathrm{CO}_{2}$ and energy use, and to identify other environmental effects that might become important once such systems are further implemented. Additionally, because the inventory of each process block highlighted areas that are responsible for significant emissions and energy consumption, this LCA was used to identify design improvements that can reduce the environmental impacts of this process. All results presented are functions of the size of the plant and this specific technology, and care should be exercised when applying them to larger or smaller facilities or generalized biomass systems.

This study sets itself apart from other LCAs that have been conducted in that all emissions, energy use, and resource consumption were assessed for each year that the system operates. The benefit of this can be seen by noting that the environment feels not an average value of the effects of this process, but the amount actually produced in a given year. Of particular significance, plant construction and decommissioning were found to have considerable levels of emissions and energy use, albeit for short periods of time compared to the system life. Thus, the average impact from 
construction and decommissioning is small, and would have been lost in the results if the analysis were not conducted on a yearly basis.

Because the trees absorb carbon dioxide as they grow, the net amount of $\mathrm{CO}_{2}$ added to the atmosphere for every unit of electricity produced can be reduced through the use of biomass power. Carbon closure, defined as the percentage of carbon in the biomass to the power plant that is recycled through the system, was found to be approximately $95 \%$. A $100 \%$ carbon closure would represent a zero-net $\mathrm{CO}_{2}$ process. How much carbon the soil can accumulate was found to have the largest effect on carbon closure. Literature values for soil carbon build-up ranged from a loss of 4.5 to a gain of $40.3 \mathrm{Mg} / \mathrm{ha} / \mathrm{seven}$ years. Applying these values, carbon closure was found to be as low as $83 \%$ and as high as $200 \%$ (i.e., a net reduction in the amount of atmospheric $\mathrm{CO}_{2}$ ). Other sensitivity cases predict that carbon closure will be greater than $94 \%$ if there is no change in the amount of carbon stored in the soil.

The net energy production of the system was found to be highly positive. One unit of energy, in the form of fossil fuels consumed within the system, is required to produce approximately 16 units of electricity that can be sent to the grid. The life cycle efficiency of the system, defined to be the energy delivered to the grid less the energy consumed by the feedstock and transportation subsystems, divided by the energy in the feedstock to the power plant, is $34.9 \%$. The power plant efficiency, defined in the traditional sense as the energy delivered to the grid divided by the energy in the biomass feedstock, is $37.2 \%$. Not including power plant parasitic losses, feedstock production accounts for $77 \%$ of the system energy consumption.

Life Cycle Assessment Results: $\mathrm{CO}_{2} \&$ Energy

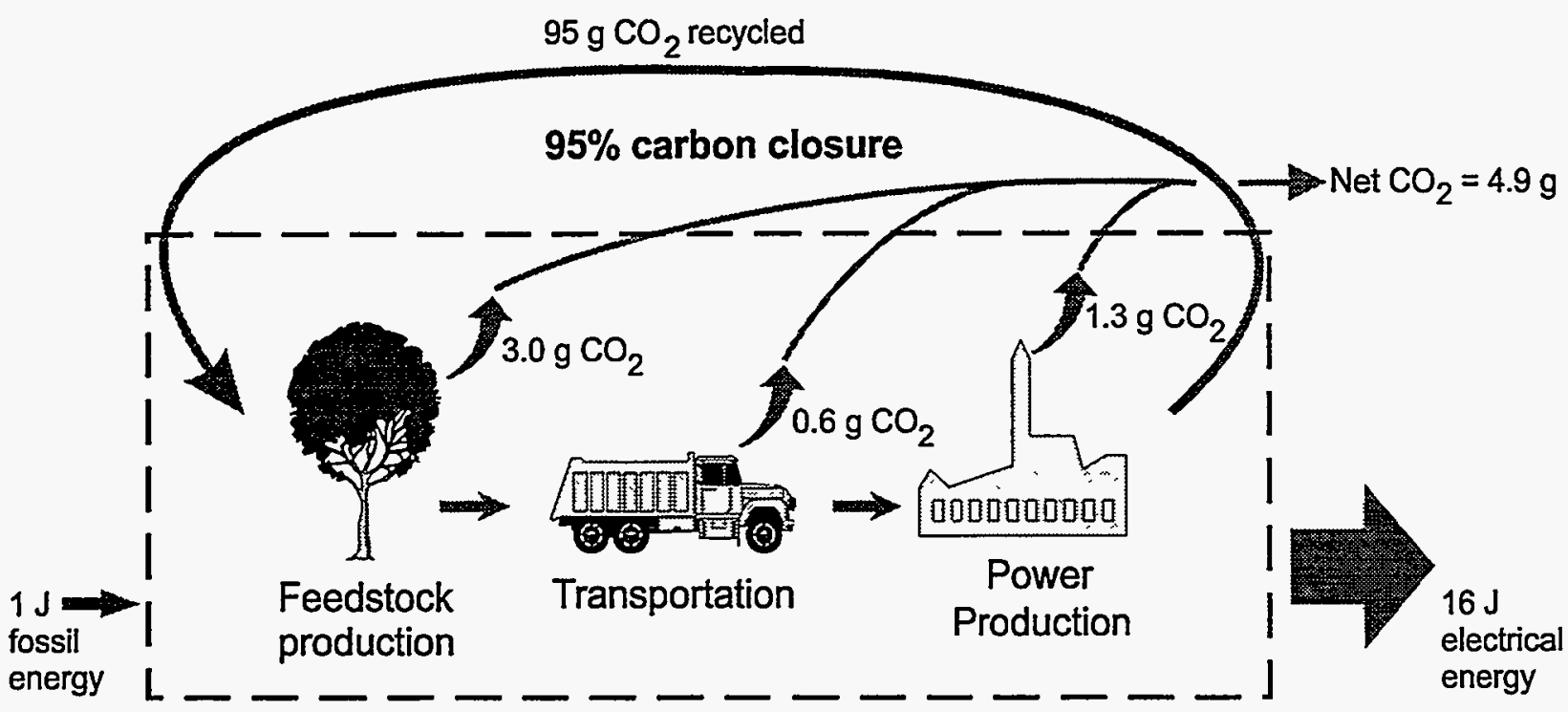

Significant air emissions were found to come from all three subsystems, but primarily from feedstock production and the power plant. $\mathrm{CO}_{2}$ is emitted in the greatest quantity, at $46 \mathrm{~g} / \mathrm{kWh}$. Isoprene, the compound used to model biogenic emissions from the trees is emitted at a rate of $21 \mathrm{~g} / \mathrm{kWh}$. NOx $(0.7 \mathrm{~g} / \mathrm{kWh})$ and non-methane hydrocarbons $(0.6 \mathrm{~g} / \mathrm{kWh})$ are the next highest emitted, followed by 
SOx $(0.3 \mathrm{~g} / \mathrm{kWh})$. From the power plant alone, NOx, SOx, and particulates are released at rates onefifth, one-tenth, and 1/28th of those required by the New Source Performance Standards (NSPS) for fossil-fueled plants. Particulate emissions, although not found to be released in significant quantities overall, are greater than six times higher during the two years of plant construction than during normal operation. Allocating the amount of $\mathrm{CO}_{2}$ absorbed by the biomass to the power plant, the percentages of total $\mathrm{CO}_{2}$ emissions from the feedstock, transportation, and power plant subsystems, respectively are $62 \%, 12 \%$, and $26 \%$. The $\mathrm{CO}_{2}$ from the power plant subsystem represents that from plant construction and decommissioning, plus emissions associated with non-renewable fuel use (such as in sand production).

Because biomass is a renewable resource, little attention has been paid to resource depletion in bioenergy systems. However, water, fossil fuels, metals, and minerals are all consumed in upstream processes required for operation of the power plant. Of all natural resources tracked, water is used at the highest rate in this system. Oil, iron, and coal account for the majority of the remaining resources consumed, and as expected, the majority of fossil fuels are consumed by farming operations in feedstock production.

Most emissions to water from the system occurred in the feedstock production subsystem, although the power plant produces a significant amount of water that will need to be treated. In general, though, the total amount of water pollutants was found to be small compared to other emissions.

Transporting the biomass to the power plant required fewer resources and less energy than both feedstock production and power plant operations. Additionally, air and water emissions are lowest from this subsystem. Therefore, changing the mode and/or emissions of biomass transportation will not greatly affect the overall impact this system has on the environment.

A sensitivity analysis was performed on the major assumptions used in the study. Each parameter was changed independently of all others so that the magnitude of its effect on the base case could be assessed. However, any effect one parameter has on another (e.g., the effect increasing biomass yield has on fossil fuel use in feedstock production) was automatically taken into account in the calculations. Decreasing the biomass yield by one-third results in the largest increase in net $\mathrm{CO}_{2}$ emissions and energy consumption. Changing the fossil fuel usage at the plantation and changing the power plant efficiency also had noticeable effects. Most important to note, however, is that the conclusions drawn from the results remain the same for all cases studied. Carbon closure is greater than $94 \%$ and the life cycle efficiency is not significantly less than the power plant efficiency. Additionally, the fossil fuel energy ratio does not drop below 11, indicating that the system will always produce significantly more usable energy than it consumes. 


\section{Table of Contents}

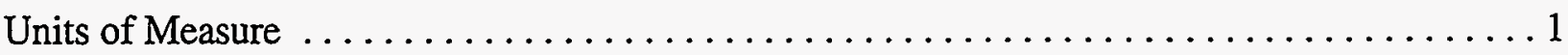

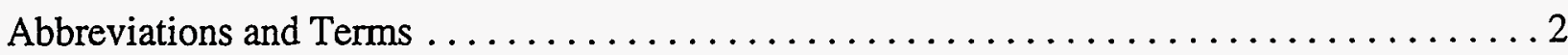

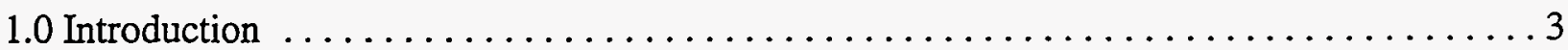

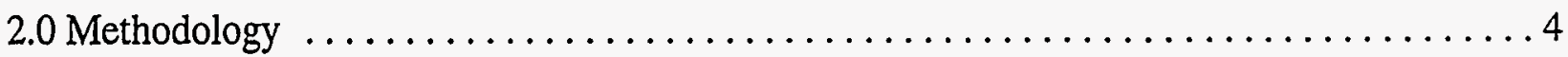

2.1 System Boundaries and Data Availability . . . . . . . . . . . . . . . . . 5

2.2 Methodology - Energy Considerations $\ldots \ldots \ldots \ldots \ldots \ldots \ldots \ldots \ldots \ldots \ldots$

2.3 Methodology - Comparison with Other Systems .................... 9

2.4 Methodology - Sensitivity Analysis ............................

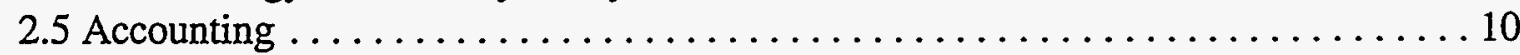

2.6 Time Frame and Issues in Assessing Environmental Consequences .......... 12

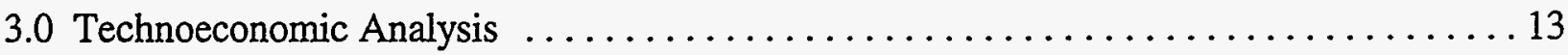

3.1 Biomass Combined Cycle System Description $\ldots \ldots \ldots \ldots \ldots \ldots \ldots \ldots \ldots \ldots \ldots \ldots \ldots$

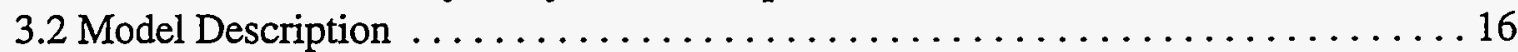

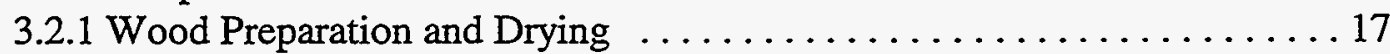

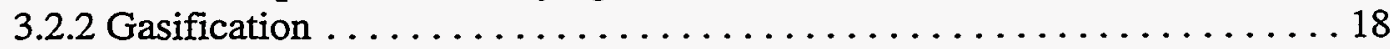

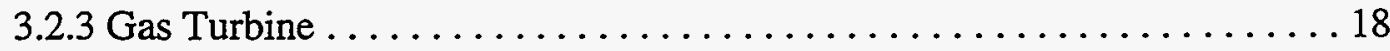

3.2.4 General Plant Requirements . . . . . . . . . . . . . . . . . 19

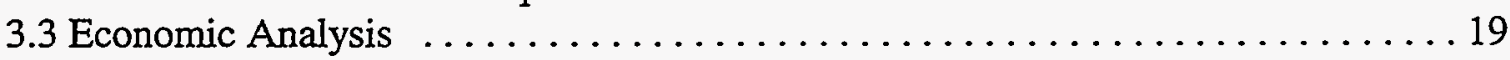

3.3.1 Economic Analysis Methodology . . . . . . . . . . . . . . . 19

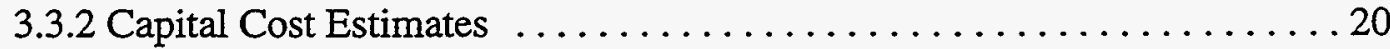

3.3.3 Overall System Performance .......................... 21

3.3.4 Economic Analysis Results ........................... 21

4.0 Description of Process Blocks Studied in the LCA $\ldots \ldots \ldots \ldots \ldots \ldots \ldots \ldots \ldots \ldots 22$

4.1 Base Case Feedstock Production Assumptions . . . . . . . . . . . . . . . 23

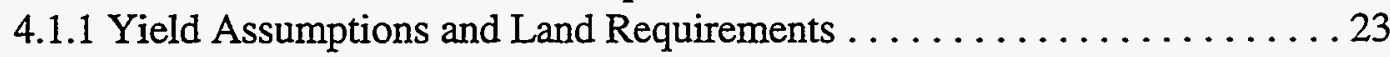

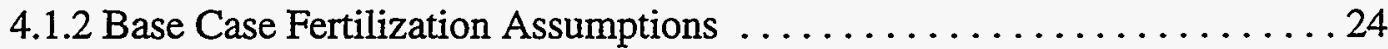

4.1.3 Base Case Herbicide and Pesticide Use .................... 25

4.1.4 Water Consumption by Biomass Plantation . . . . . . . . . . . 27

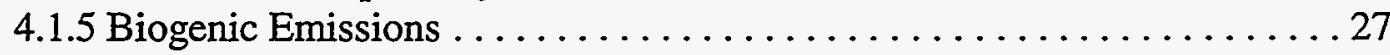

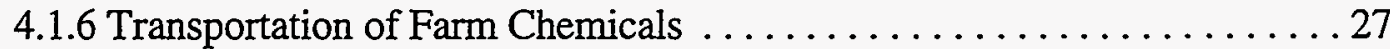

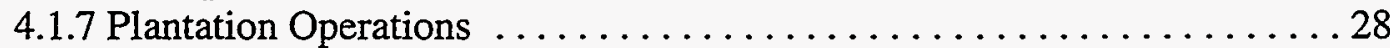

4.1.8 Soil Carbon Sequestration Base Case .................... 31

4.2 Base Case Biomass Transportation Assumptions .................... 33

4.3 Base Case Power Plant Construction \& Decommissioning Assumptions ........ 34

4.4 Base Case Power Generation Assumptions . . . . . . . . . . . . . . . . . 35

4.4.1 Biomass Storage \& Drying . . . . . . . . . . . . . . . . . . 37

4.4 .2 Gasifier/Combustor ................................... 38

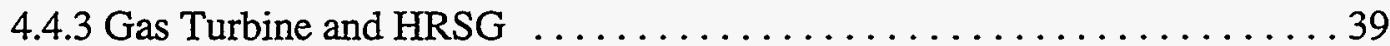


4.4.4 Water Requirements \& Treatment $\ldots \ldots \ldots \ldots \ldots \ldots \ldots \ldots \ldots \ldots \ldots$

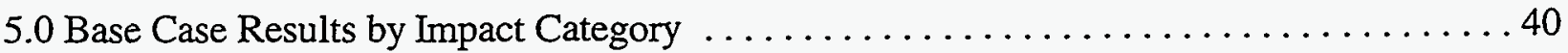

5.1 Air Emissions . . . . . . . . . . . . . . . . . . . . . . . . . . . 44

5.1.1 Carbon Dioxide Emissions . . . . . . . . . . . . . . . 46

5.1.2 Air Emissions from the Power Plant: Non-Methane Hydrocarbons, NOx, and SOx .................................. 47

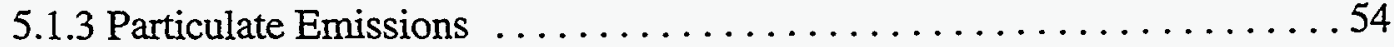

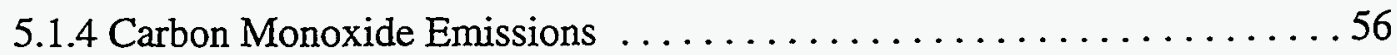

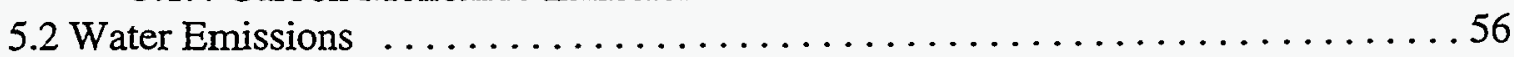

5.3 Energy and Resource Consumption .......................... 56

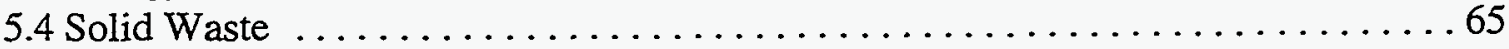

6.0 Results Specific to the Three Major Subsystems ........................ 65

6.1 Base Case Feedstock Production Results . . . . . . . . . . . . . . . . . 65

6.2 Base Case Biomass Transportation Results ..................... 72

6.3 Base Case Power Plant Construction \& Decommissioning Results .......... 72

6.4 Base Case Power Generation Results $\ldots \ldots \ldots \ldots \ldots \ldots \ldots \ldots \ldots \ldots \ldots$

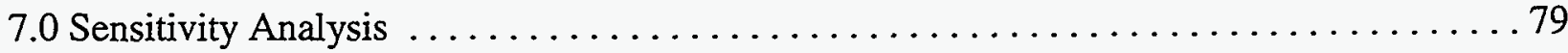

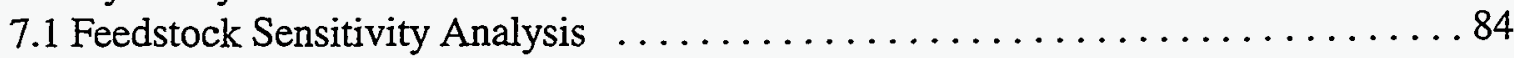

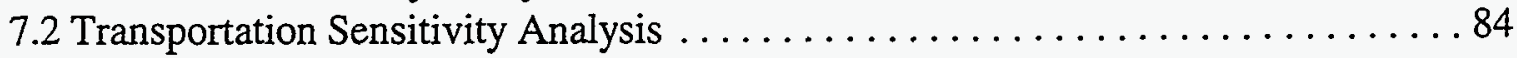

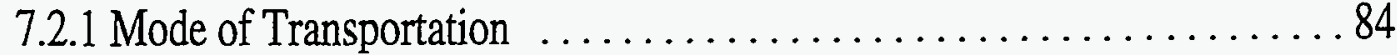

7.2.2 Transportation Distance $\ldots \ldots \ldots \ldots \ldots \ldots \ldots \ldots \ldots \ldots \ldots . \ldots \ldots$

7.3 Power Plant Construction \& Decommissioning Sensitivity Analysis . . . . . . . 88 8

7.4 Landfilling versus Recycling Sensitivity Analysis $\ldots \ldots \ldots \ldots \ldots \ldots . \ldots . \ldots 89$

7.5 Power Generation Sensitivity Analysis $\ldots \ldots \ldots \ldots \ldots \ldots \ldots \ldots \ldots \ldots . \ldots \ldots$

7.5.1 NOx Produced .................................. 89

7.5.2 Power Plant Efficiency ............................ 89

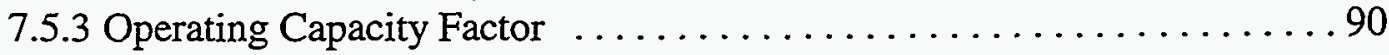

8.0 Impact Assessment . . . . . . . . . . . . . . . . . . . . . . . . . . 90

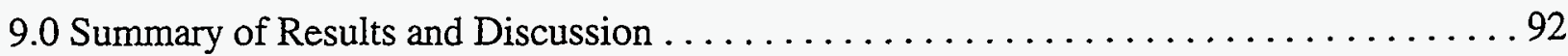

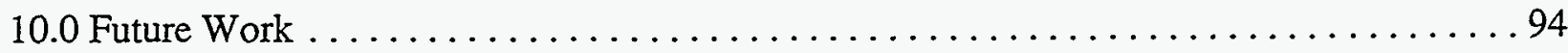

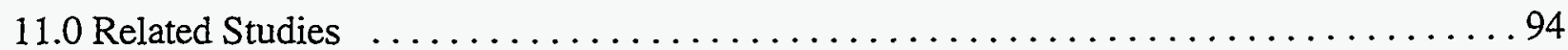

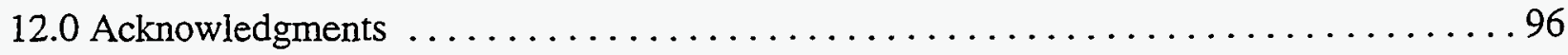

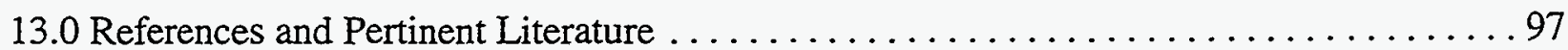




\section{List of Figures}

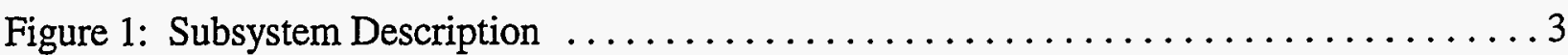

Figure 2: System Concept in Life Cycle Assessment $\ldots \ldots \ldots \ldots \ldots \ldots \ldots \ldots \ldots \ldots \ldots \ldots \ldots$

Figure 3: Biomass Production and Transportation Boundaries for Life Cycle Assessment . . . 7

Figure 4: Power Generation and Transportation Boundaries for Life Cycle Assessment . . . . . 8

Figure 5: Low Pressure Indirect BIGCC Schematic $\ldots \ldots \ldots \ldots \ldots \ldots \ldots \ldots \ldots \ldots \ldots \ldots \ldots \ldots$

Figure 6: General Sources of Power Plant Emissions $\ldots \ldots \ldots \ldots \ldots \ldots \ldots \ldots \ldots \ldots \ldots \ldots \ldots \ldots \ldots \ldots$

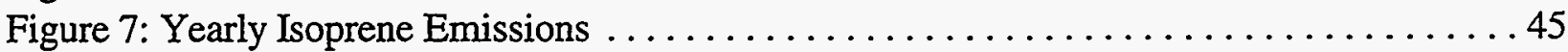

Figure 8: Carbon Closure for Various Literature Values of Soil Sequestration $\ldots \ldots \ldots \ldots 48$

Figure 9: Life Cycle Flows of $\mathrm{CO}_{2}$ within a Biomass Power System .............. 49

Figure 10: Yearly Net $\mathrm{CO}_{2}$ Emissions Over the Life of the System $\ldots \ldots \ldots \ldots \ldots \ldots \ldots$

Figure 11: Yearly Non-Methane Hydrocarbon Emissions $\ldots \ldots \ldots \ldots \ldots \ldots \ldots \ldots \ldots \ldots \ldots \ldots \ldots$

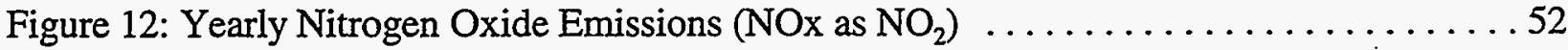

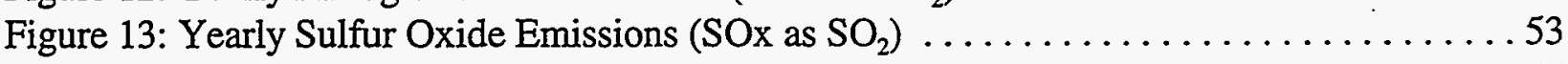

Figure 14: Yearly Particulate Emissions Over the Life of the System $\ldots \ldots \ldots \ldots \ldots \ldots 5$

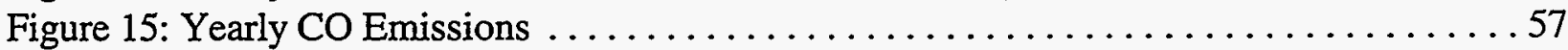

Figure 16: Yearly Total Energy Consumption Over the Life of the System $\ldots \ldots \ldots \ldots \ldots 58$

Figure 17: Life Cycle Energy Flows within a Biomass Power System . . . . . . . . . . . . 59

Figure 18: Yearly Oil Consumption .................................. 61

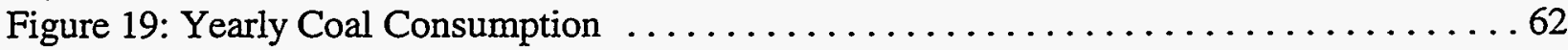

Figure 20: Yearly Natural Gas Consumption $\ldots \ldots \ldots \ldots \ldots \ldots \ldots \ldots \ldots \ldots \ldots \ldots \ldots \ldots \ldots \ldots \ldots$

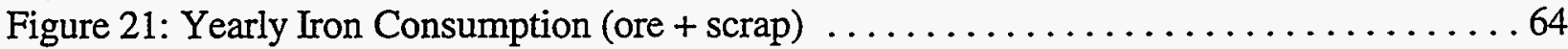

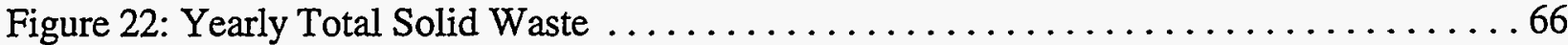

Figure 23: A Breakdown of Energy Consumption in Feedstock Production . . . . . . . . . . 67

Figure 24: A Breakdown of $\mathrm{CO}_{2}$ Emissions in Feedstock Production $\ldots \ldots \ldots \ldots \ldots 66$

Figure 25: A Breakdown of Particulate Emissions in Feedstock Production . ...........6 69

Figure 26: A Breakdown of Non-Methane Hydrocarbon Emissions in Feedstock Production . 70

Figure 27: A Breakdown of Plant Construction $\mathrm{CO}_{2}$ Emissions $\ldots \ldots \ldots \ldots \ldots \ldots \ldots \ldots$

Figure 28: A Breakdown of Plant Construction Electricity Requirements . . . . . . . . . . 76

Figure 29: A Breakdown of Non-Electric Energy Requirements for Plant Construction . . . . 77

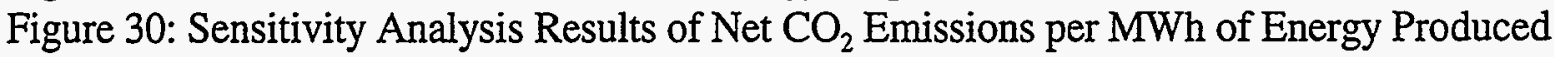

Figure 31 : Sensitivity Analysis Results of System Energy Consumption per $\mathrm{MWh}_{\mathrm{W}}$ of Energy

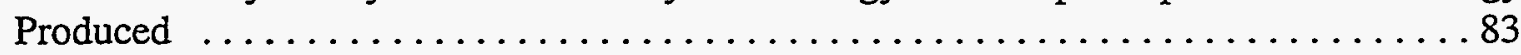

Figure 32: Sensitivity Analysis Results for Carbon Closure $\ldots \ldots \ldots \ldots \ldots \ldots \ldots \ldots . \ldots . \ldots . \ldots$

Figure 33: Sensitivity Analysis Results for Life Cycle Efficiency $\ldots \ldots \ldots \ldots \ldots \ldots . \ldots 8$

Figure 34: Sensitivity Analysis Results for Fossil Fuel Energy Ratio . . . . . . . . . . . 87 


\section{List of Tables}

Table 1: Process Blocks Taken from DEAM . . . . . . . . . . . . . . . . 11

Table 2: Major Yearly Operations of the Three Subsystems $\ldots \ldots \ldots \ldots \ldots \ldots \ldots \ldots \ldots$

Table 3: Biomass Analysis - Ultimate Analysis for Hybrid Poplar . . . . . . . . . . . 17

Table 4: Gasifier Product Gas Composition, Dry Basis $\ldots \ldots \ldots \ldots \ldots \ldots \ldots \ldots$

Table 5: Gasifier Design Parameters and Operating Conditions . . . . . . . . . . . . 18

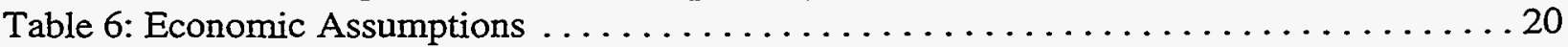

Table 7: Factors Used for Calculation of Total Direct Plant Cost $\ldots \ldots \ldots \ldots \ldots \ldots \ldots 21$

Table 8: Process Data Summary and System Performance Results . . . . . . . . . . . 21

Table 9: Summary of Technoeconomic Analysis Results . . . . . . . . . . . . . 22

Table 10: Short Rotation Woody Crop Yields . . . . . . . . . . . . . . . . . 24

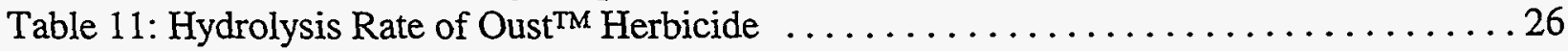

Table 12: Plantation Operations and Necessary Machinery $\ldots \ldots \ldots \ldots \ldots \ldots \ldots \ldots \ldots$

Table 13: Materials Required for Machinery Complement Construction . . . . . . . . . . . 30

Table 14: Materials Required for Harvesting Equipment and Tractor Construction . . . . . . . 30

Table 15: Annual Fuel and Oil Requirements for Farming Operations . . . . . . . . . . 32

Table 16: Truck and Train Material Requirements . . . . . . . . . . . . . . . 34

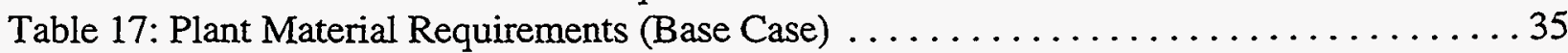

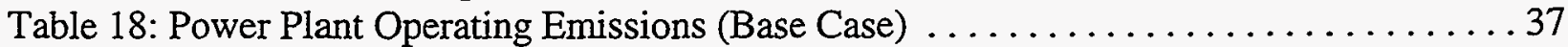

Table 19: Average Air Emissions per $\mathrm{kWh}$ of Net Electricity Produced . . . . . . . . . . 41

Table 20: Average Water Emissions per $\mathrm{kWh}$ of Net Electricity Produced . . . . . . . . 42

Table 21: Average Energy Requirements per kWh of Net Electricity Produced ... . . . . . 42

Table 22: Average Resource Consumption per $k W h$ of Net Electricity Produced . . . . . . 43

Table 23: Average Solid Waste Generation per kWh of Net Electricity Produced . . . . . . 43

Table 24: New Source Performance Standards for Fossil-Fueled Power Plants ... . . . . . . 54

Table 25: Sediment Loss Measured in First Two Years of Growth in Recent Field Trials . . . 71

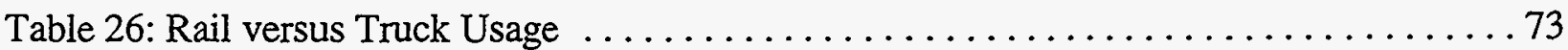

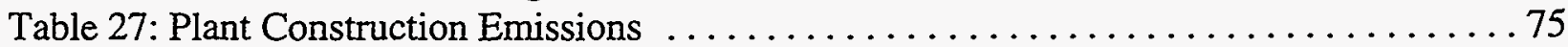

Table 28: Comparison of Construction and Total Emissions in Years -1 and $-2 \ldots \ldots \ldots 78$

Table 29: Sensitivity Analysis Cases . . . . . . . . . . . . . . . . . . . 80

Table 30: Sensitivity Analysis Condensed Results $\ldots \ldots \ldots \ldots \ldots \ldots \ldots \ldots \ldots \ldots \ldots$

Table 31: Plant Material Requirements Used in Sensitivity $\ldots \ldots \ldots \ldots \ldots \ldots \ldots$

Table 32: Stressor Categories Associated with Biomass Power Production . . . . . . . . .91

\section{Appendices}

Appendix A: Graphical Representation of the LCA System in TEAM

Appendix B: Details of Some DEAM Database Modules 


\section{Units of Measure}

Except for data on farming operations, which are generally stated in English units of measure, metric units of measure are used in this report. All energy balance results reported in the inventory assessment are based on the amount of material consumed for the amount of electricity produced by the plant in one year. Therefore, material consumption is reported in units based on the gram (e.g., kilogram or megagram), energy consumption based on the joule (e.g., kilojoule or megajoule), and distance based on the meter (e.g., kilometer). When it can contribute to the understanding of the analysis, the English system equivalent is stated in parenthesis. Below are the metric units used in this report with the corresponding conversions to English equivalents.

$\begin{array}{ll}\text { Mass: } & \text { kilogram }(\mathrm{kg})=2.205 \text { pounds } \\ & \text { megagram }(\mathrm{Mg})=\text { metric tonne }(\mathrm{T})=1 \times 10^{6} \mathrm{~g}=1.102 \text { ton }(\mathrm{t}) \\ \text { Distance: } & \text { kilometer }(\mathrm{km})=0.62 \text { mile }=3,281 \text { feet } \\ \text { Area: } & \text { hectare }(\mathrm{ha})=10,000 \mathrm{~m}^{2}=2.47 \text { acres } \\ \text { Volume: } & \text { cubic meter }\left(\mathrm{m}^{3}\right)=264.17 \text { gallons } \\ \text { Pressure: } & \text { kilopascals }(\mathrm{kPa})=0.145 \text { pounds per square inch } \\ \text { Energy: } & \text { gigajoule }(\mathrm{GJ})=0.9488 \mathrm{MMBtu}(\text { million Btu }) \\ & \text { kilowatt-hour }(\mathrm{kWh})=3,414.7 \mathrm{Btu} \\ & \text { gigawatt-hour }(\mathrm{GWh})=3.4 \times 10^{9} \mathrm{Btu} \\ \text { Power: } & \text { megawatt }(\mathrm{MW})=1 \times 10^{6} \mathrm{~J} / \mathrm{s} \\ \text { Temperature: } & { }^{\circ} \mathrm{C}=\left({ }^{\circ} \mathrm{F}-32\right) / 1.8\end{array}$




\section{Abbreviations and Terms}

ASPEN - Advanced System for Process ENgineering (software is ASPEN Plus ${ }^{\mathrm{TM}}$ by ASPEN Technologies, Inc.)

BCL - Battelle Columbus Laboratories

BIGCC - biomass integrated gasification combined cycle

CCT - Clean Coal Technology Program

COE - cost of electricity

DEAM - Data for Environmental Analysis and Management (TEAM database)

DFSS - dedicated feedstock supply system

DOE - United States Department of Energy

FERCO - Future Energy Resources Corporation

HC - unspecified hydrocarbons

HHV - higher heating value

HRSG - heat recovery steam generator

IGCC - integrated gasification combined cycle

ISO - International Organization for Standardization

LHV - lower heating value

MAF - moisture and ash free

MMBtu - million British thermal units

NMHC - non-methane hydrocarbons, including VOCs

NREL - National Renewable Energy Laboratory

NSPS - New Source Performance Standard

ORNL - Oak Ridge National Laboratory

Plant (noun) - the power plant

Plant (verb) - establishment of biomass in field

SCR - selective catalytic reduction

Stressor - A term that collectively defines emissions, resource consumption, and energy use; a substance or activity that results in a change to the natural environment

Stressor category - A group of stressors that defines possible impacts

TEAM - Tools for Environmental Analysis and Management (software by Ecobalance, Inc.)

TCR - total capital requirements

TPC - total plant cost

TPI - total plant investment

VOC - volatile organic compound 


\subsection{Introduction}

The potential environmental benefits from biomass power are numerous. In addition to a dramatic decrease in the amount of carbon dioxide produced per $\mathrm{kWh}$, implementation of biomass power systems will reduce fossil fuel consumption and significantly mitigate sulfur and nitrogen oxide emissions. Additionally, compared to conventional crops, biomass plantations may increase biodiversity and soil carbon, and reduce soil erosion. However, biomass power may also have some negative effects on the environment. Although the environmental benefits and drawbacks of biomass power have been debated for some time, the total significance has not been assessed. This study serves to answer some of the questions most often raised in regard to biomass power: What are the net $\mathrm{CO}_{2}$ emissions? What is the energy balance of the integrated system? Which substances are emitted at the highest rates? What parts of the system are responsible for these emissions?

To provide answers to these questions, a life cycle assessment (LCA) of a hypothetical biomass power plant located in the Midwest United States was performed. LCA is an analytical tool for quantifying the emissions, resource consumption, and energy use, collectively known as environmental stressors, that are associated with converting a raw material to a final product. Performed in conjunction with a technoeconomic feasibility study, the total economic and environmental benefits and drawbacks of a process can be quantified. This study complements a technoeconomic analysis of the same process, reported in Craig and Mann (1996) and updated here.

The process studied is based on the concept of power generation in a biomass integrated gasification combined cycle (BIGCC) plant. Broadly speaking, the overall system consists of biomass production, its transportation to the power plant, electricity generation, and any upstream processes required for system operation (see Figure 1). The biomass is assumed to be supplied to the plant as wood chips from a biomass plantation, which would produce energy crops in a manner similar to the way food and fiber crops are produced today. Transportation of the biomass and other materials is by both rail and truck. The IGCC plant is sized at $113 \mathrm{MW}$, and integrates an indirectly-heated gasifier with an industrial gas turbine and steam cycle.

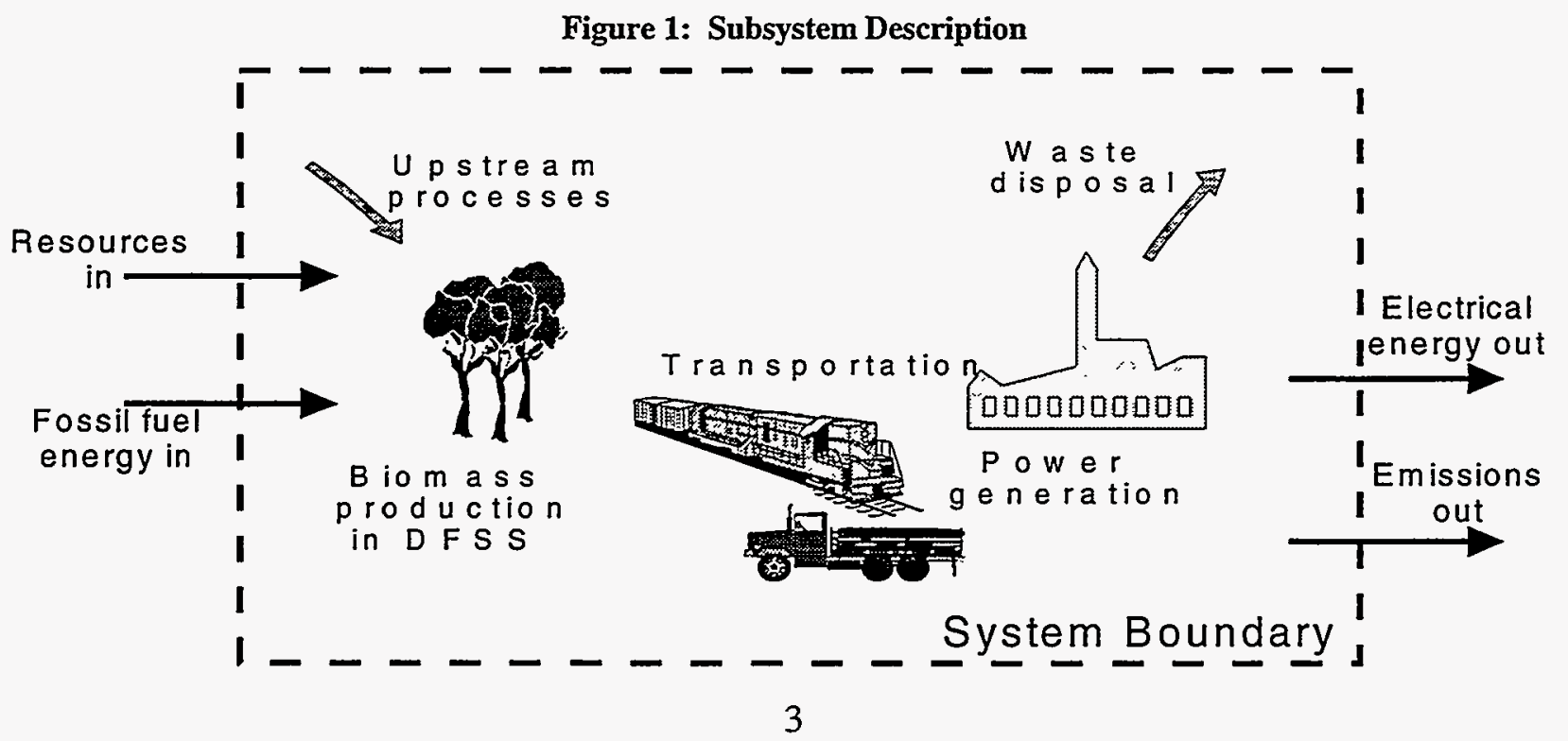


Although a significant amount of work has been performed on many parts of this system or similar systems, very little has been done from a life cycle viewpoint. For example, earlier studies have assessed the energy used at the biomass plantation, but did not include upstream operations such as raw material extraction or equipment manufacture (see section 11.0). Moreover, processes required for biomass production have not formerly been integrated with transportation and electricity production for the purpose of identifying major emissions beyond $\mathrm{CO}_{2}$. Unlike previous efforts, this study serves to pull together all major operations involved in producing electricity from biomass, while identifying a large number of possible stressors on the environment.

Generally, a life cycle assessment is conducted on two competing processes. Such a comparative analysis highlights the environmental benefits and drawbacks of one process over the other. In keeping with the primary purpose of this study, to better define the environmental aspects of this process irrespective of any competing process, a comparative analysis was not performed. Future work, however, will seek to answer the question of how this process measures up environmentally against other renewable and fossil-based systems.

Frequently, others perform life cycle assessments in order to respond to criticism about the environmental effects of a product or to address a limited number of possible consequences. In doing so, only data that are required to address the goals of the project while keeping the scope of the assessment reasonable are included. In conducting this life cycle assessment, every effort was made to include all correct and best available data. Since the primary goal of this work is to identify sources of environmental concern and to discover possible design improvements to mitigate these concerns, it is our intention to report all possible environmental impacts of the process. Unfortunately, because no biomass-based IGCC plants are currently operating, it will be difficult to validate some of the assumptions used in this study for some time. The system being assessed is conceptual, and represents only what an integrated power facility using biomass grown as a dedicated feedstock might look like. However, emissions from the power plant itself may be verifiable from tests on the demonstration facility now being constructed in Burlington, Vermont. Additionally, biomass test plots will continue to provide more accurate information on required feedstock production operations and what environmental effects are likely. This study will be regularly updated as real operating data become available.

\subsection{Methodology}

In the United States, the Society of Environmental Toxicology and Chemistry (SETAC) has been actively working to advance the methodology of life cycle assessment through workshops and publications. From their work, a three-component model for life cycle assessment has been developed (SETAC, 1991), and is considered to be the best overarching guide for conducting such analyses. The three components are inventory, impact analysis, and improvement. The inventory stage involves quantifying the energy and material requirements, air and water emissions, and solid waste from all stages in the life of a product or process. The second element, impact assessment, examines the environmental and human health effects associated with the loadings quantified in the inventory stage. The final component is an improvement assessment in which means to reduce the 
environmental burden of a process are proposed and implemented. It should be emphasized that life cycle assessments are not necessarily performed step-wise and that they are dynamic rather than static. For example, process improvements may become obvious during the inventory assessment phase, and altering the process design will necessitate a reevaluation of the inventory. Additionally, depending on the purpose of the LCA, an impact assessment may not be necessary. Most importantly, a life cycle assessment needs to be evaluated periodically to take into account new data and experiences gained. To date, most work in life cycle assessment has focused on inventory, although efforts to advance impact assessment and improvement are significant. The International Organization for Standardization (ISO) is also involved in life cycle assessment development under the new ISO 14000 environmental management standards. Specifically, the Sub-Technical Advisory Group working on this task has made progress in constructing inventory assessment guidelines, but much disagreement remains on the impact and improvement elements.

A detailed inventory was conducted for this study, and is the subject of most of the results presented in this report. Additionally, some very simple design changes were made to the power plant, and recommendations for further process improvements are made. Methodology development for performing impact assessments is in its infancy and felt to have limited value for achieving the goals of this work. Therefore, only a cursory examination of the environmental effects was performed. This consisted of placing each stressor (e.g., $\mathrm{CO}_{2}$, coal consumption) into an impact category (e.g., greenhouse gas, resource depletion, etc.). It is important to note that even without a full impact analysis, recommendations for process improvements can be made by identifying major sources of environmental stressors.

\subsection{System Boundaries and Data Availability}

The system boundaries for any life cycle assessment should be drawn as broadly as possible. In addition to counting the material and energy flows of the primary process of interest, those processes involved in the extraction of raw materials and production of intermediate feedstocks must be included. Intermediate feedstocks are sometimes referred to as ancillary materials because they are used indirectly in the manufacture of the final product (e.g., the fertilizer needed to grow biomass). The means of disposing products, by-products, wastes, and process materials are also included within the life cycle boundary. The system concept diagram shown in Figure 2 serves to better describe the meaning of terms such as boundary, process, intermediate feedstock, and materials. 
Figure 2: System Concept in Life Cycle Assessment

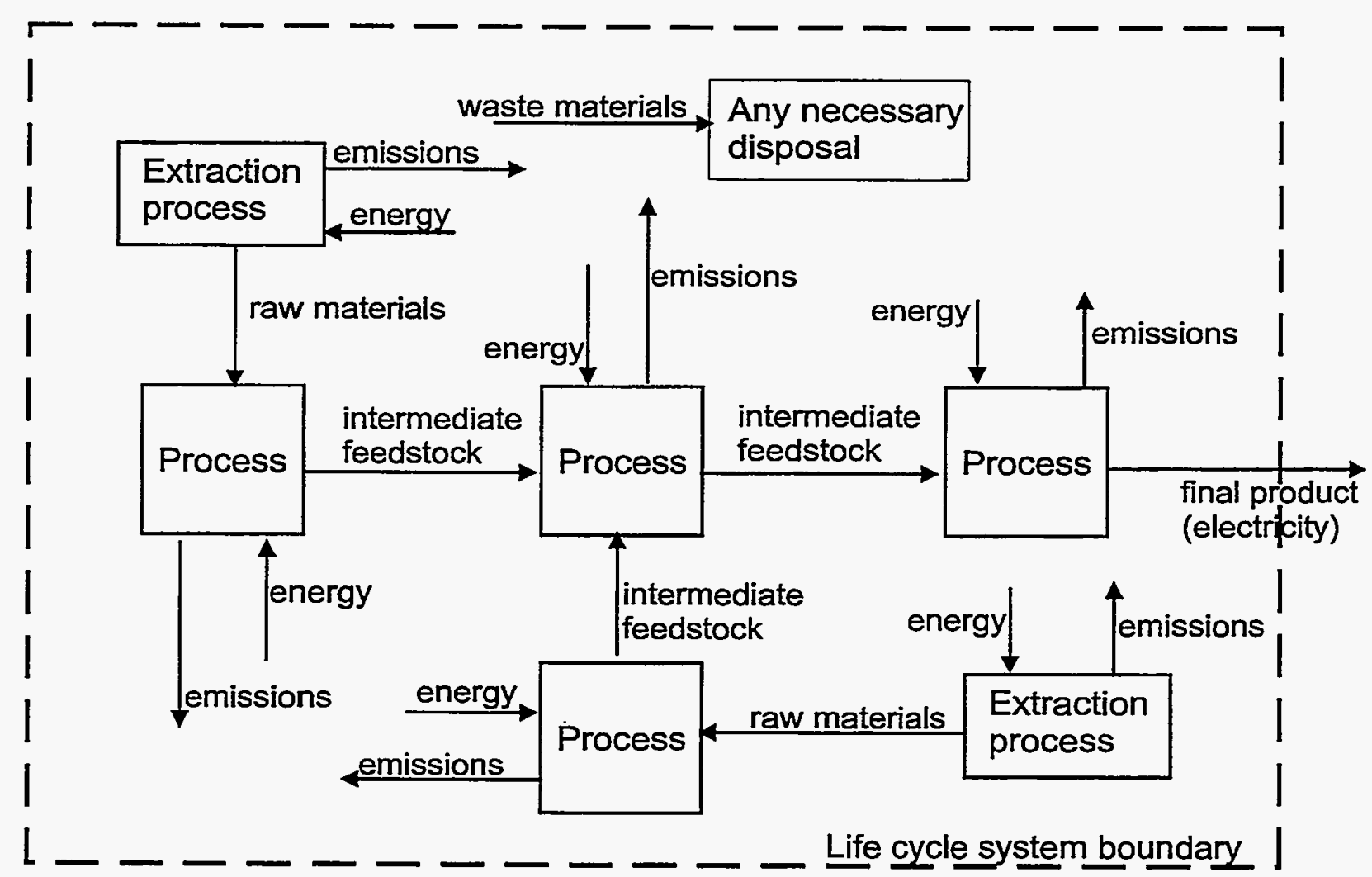

The question of where to stop tracking the energy and material uses of upstream processes is an important one since the analysis is infinite if boundaries are not drawn to encompass the most important impacts to the environment. Generally speaking, the impacts of upstream processes become less significant the further you get from the process of interest, and a situation of diminishing returns becomes apparent past the third level of upstream processes. Conducting a life cycle assessment can be extremely time consuming, and as part of the scoping process, decisions should be made to determine at which point the results will have limited use. Very often, the determination of system boundaries is made based on data availability, and to a large extent, this is how the present analysis was conducted. Data exist on the extraction of natural resources, processing, manufacture, and delivery to the point of use for most process feedstocks, such as diesel fuel and ammonium nitrate fertilizer. Thus, the assessment included nearly all of the major processes necessary to produce electricity from biomass. Examples of operations that were felt to be too far from the system of interest to be included in the study are the construction of facilities to manufacture transportation equipment, and manufacture of mining equipment. Additionally, because of a complete lack of information, seedling production was not included in the analysis. Perlack $e t$ al (1992) report that the effects of this step will be negligible on regional and global scales, but could be important locally. Figures 3 and 4 show the processes included in the overall system. The solid lines in these figures represent actual material and energy flows, while the dotted lines indicate 


\section{Figure 3: Biomass Production and Transportation Boundaries for Life Cycle Assessment}

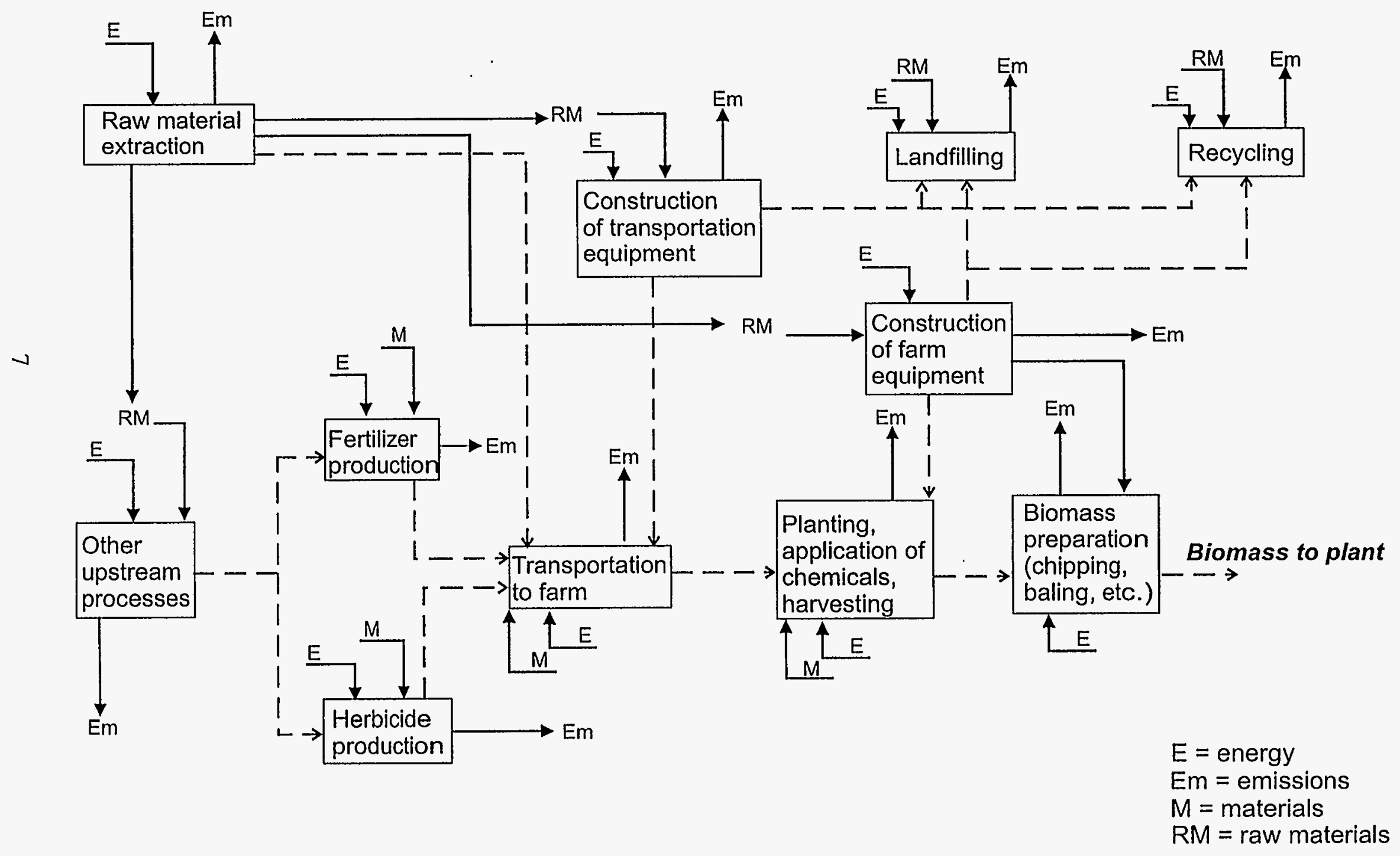




\section{Figure 4: Power Generation and Transportation Boundaries for Life Cycle Assessment}

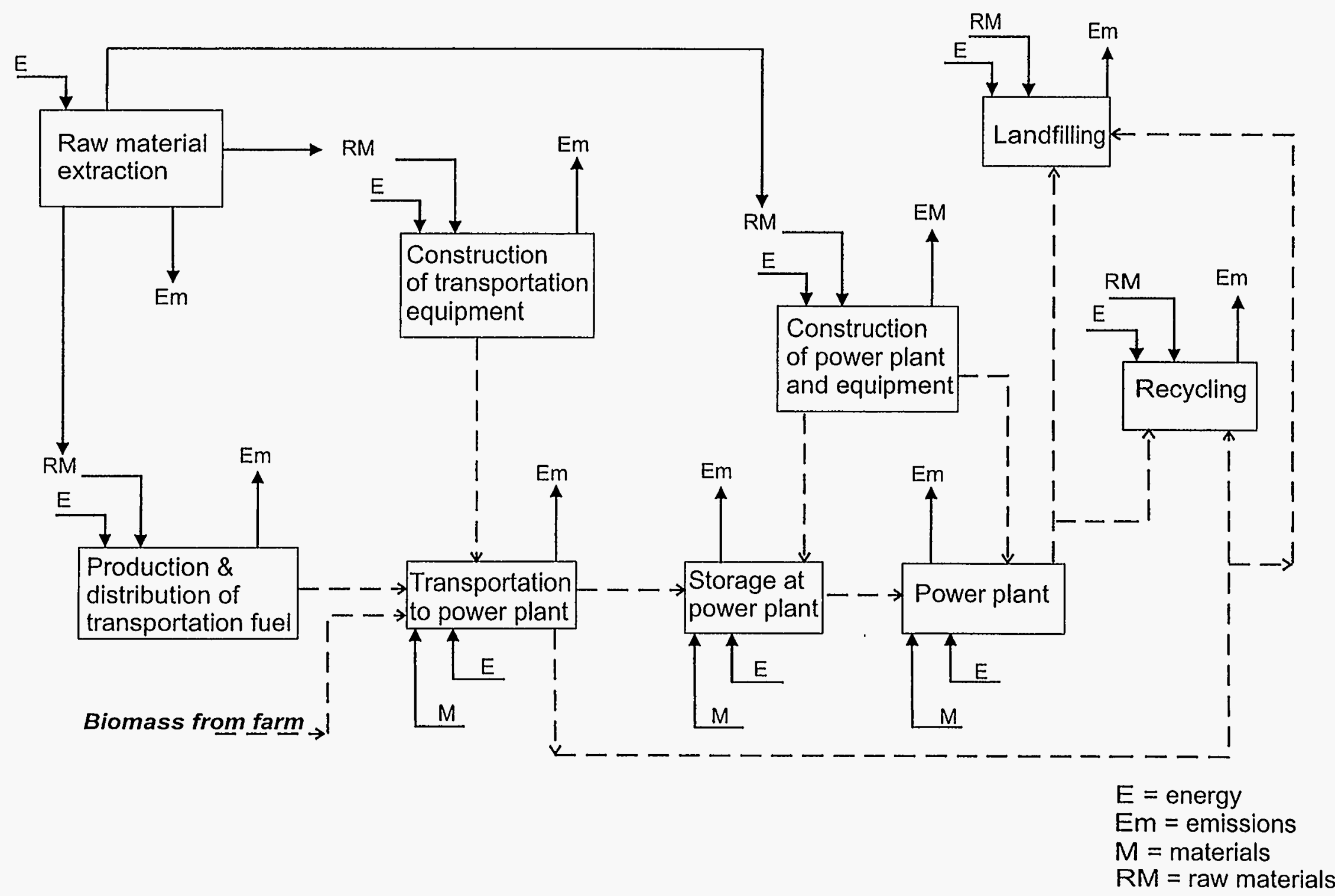


logical connections between process blocks. In Figure 3, "Other upstream processes" refers to major manufacturing steps needed to produce intermediate feedstocks such as ammonia required for ammonium nitrate production.

\subsection{Methodology - Energy Considerations}

The energy use within the system was tracked so that the net energy production could be assessed. Two types of energy were accounted for: 1) energy used directly in each process block, and 2) energy contained in the materials used in each process block. In the case of a power plant, all energy used in these categories is subtracted from the energy produced as electricity. Examples of the first type of energy consumption include the electricity required to run equipment such as compressors and the fuel used in transportation. The second type of energy, that contained in the raw materials and intermediate feedstocks, is the sum of combustion and process energies; this is sometimes referred to as the embodied energy of a material. The combustion energy is applied where nonrenewable fuels are consumed, and is the energy that would be released during combustion of the fuel (i.e., its heating value). This practice reflects the fact that the fuel has a potential energy that is being consumed by the system. The combustion energy of renewable resources, those replenished at a rate equal to or greater than the rate of consumption, was not subtracted from the net energy of the system. This is because, on a life cycle basis, the resource is not being consumed. The second part of embodied energy, process energy, is the total amount of energy consumed in all upstream processes used to bring the raw material or intermediate feedstock to the system in the form in which it is used. To determine the net energy in this LCA, the energy used directly in each block plus the embodied energy of all materials consumed by the system, were subtracted from the energy produced by the power plant.

\subsection{Methodology - Comparison with Other Systems}

It has already been stated that this analysis was performed only on the biomass system, and not for the immediate comparison with fossil-fueled power options. Additionally, prior land use considerations were not made, and a comparison of biomass crops with other crops was not included. Prior land use will certainly affect many of the variables used in this study. For example, what was grown on the plantation before biomass crops will affect soil carbon sequestration and how much fertilization and tilling are required. Regardless, existing experience with biomass simply does not provide enough parametric data, thus making it necessary to base inputs for this study on the best information available from recent field trials. Additionally, although it would be useful to compare the environmental effects of dedicated energy crops to agriculture crops, lack of data and the desire to stay focused on the main aspects of biomass power require a deferment to later studies.

\subsection{Methodology - Sensitivity Analysis}

A sensitivity analysis was conducted to determine the parameters that had the largest effects on the results and to minimize the impact of incorrect data on the conclusions. Variables included in the sensitivity analysis were chosen to reflect system areas that had inherently more unknowns in the 
data. Examples include feedstock yield, fossil fuel use at the plantation, thermal NOx emissions, and power plant operating capacity. Each parameter was changed independently of the others, giving the change in results in relation to only that variable. Therefore, no one single sensitivity case reflects the best-case or worse-case scenarios for this process. It's important to note, however, that upstream material and energy uses affected by a parameter included in the sensitivity analysis, were automatically changed in the model. For example, since fertilizer use is calculated in $\mathrm{kg} / \mathrm{acre}$, the total amount of fertilizer applied was automatically increased in the sensitivity case that examined lower biomass productivity.

\subsection{Accounting}

Keeping track of the large number of material and energy flows to and from the process blocks within the system represents an enormous accounting challenge. Several software packages, designed specifically for life cycle assessment, are available to make this job easier. Many include, as part of their database, processes that are commonly encountered such as the extraction of raw materials or the production of large market chemicals. The software package chosen for this study was Tools for Environmental Analysis and Management (TEAM), by Ecobalance, Inc. Originally developed in France, this software has been adapted to reflect standard energy and chemical processes in the United States. The process blocks within the biomass-based power production system that were available in the TEAM database, known as Data for Environmental Analysis and Management (DEAM) are shown in the following table. Note that this table includes only those process blocks taken from the DEAM database and not all of those in the assessment. Production of raw materials includes extraction, any necessary refining, and transportation to point-of-use. Each of the operations in the table contains the emissions, raw material use, and energy consumption of nearly all upstream processes. For example, ammonia production includes natural gas extraction, reforming, and ammonia synthesis. The data within TEAM were checked against other sources to determine reliability. In general, the data were found to be consistent with those found in the literature. In particular, the energy embodied in fossil fuels and certain commodity chemicals was checked against data in Boustead and Hancock (1979), Fluck (1992), Pimentel (1980), and Cervinka (1980). DEAM databases on the production of fertilizers were found to be consistent with the extensive amount of information found in the literature (see Feedstock Production Literature in the References section at the back of this report). 
Table 1: Process Blocks Taken from DEAM

\begin{tabular}{|l|}
\hline Coal production \\
\hline Natural gas production \\
\hline Diesel oil production \\
\hline Electricity production (U.S. overall and region-specific) \\
\hline Diesel oil combustion (for truck transport and farm equipment operation) \\
\hline Light fuel oil production \\
\hline Light fuel oil combustion \\
\hline Aluminum production from ore and scrap \\
\hline Steel production from ore and scrap \\
\hline Iron production from ore and scrap \\
\hline Landfilling waste materials \\
\hline Potash fertilizer production \\
\hline Phosphate fertilizer production \\
\hline Nitric acid production \\
\hline Limestone production \\
\hline
\end{tabular}

Processes within the system that were not available in DEAM were constructed manually. Data were obtained from the literature and from researchers in biomass production and use, and entered into TEAM. Calculations were then performed using TEAM on the entire system and reported in spreadsheet format. For additional information on how process blocks are connected, the screen printouts from the TEAM software for this analysis are attached as Appendix A. Sufficient data were not available on some novel processes within the system such as gas turbine combustion of biomass-derived synthesis gas and all of the specifics of biomass production. The data used in these areas were taken from research and documented studies. Additionally, data that are site-specific, such as soil erosion and feedstock transportation requirements were based on averages from field studies or best-guess approximations.

The functional unit, also known as the production amount that represents the basis for the analysis, was chosen to be unit of energy produced. Most results are presented per kWh or per MWh of net electricity produced by the power plant. Because the emissions, resources consumed, and energy use are functions of the size of the plant and the technology, care should be taken in scaling results to larger or smaller facilities, or applying them to other biomass systems. 


\subsection{Time Frame and Issues in Assessing Environmental Consequences}

Most life cycle assessments are performed on a plant-life basis. That is, the material and energy flows represent values seen in normal operating years or values averaged as though they are the same each year. However, because the environment experiences the impacts when they actually occur, averaging emissions and resource depletion makes the consequences look better or worse than they really are at any time during system operation. This is especially true in a system using biomass since resource production is initiated several years before plant operation begins, and tapers off in the final years when the plant is still operating at full capacity. Therefore, this study was conducted on a yearly basis, taking into account each emission and resource use in the year it occurs. To obtain this information, a separate inventory of the system was conducted 37 times, once for each year of operation.

The power plant life was set at 30 years. Because biomass is assumed to be grown on seven year rotations, the total operation of the system was 37 years. Year one is that in which the power plant begins to operate. Years negative seven through negative three consist solely of growing the biomass. No special preparation time is allotted for converting the field from its prior use to a biomass plantation. Both biomass production and plant construction take place in the two years before plant start-up (year negative two and negative one). In years one through 29 , biomass production and normal plant operation occur, with the number of fields in production decreasing by one per year from seven to zero in year 30 when the power plant is decommissioned. Table 2 more clearly spells out the operations that take place each year. The amount of biomass in production in any year is related to how much has to be supplied to the power plant at the end of the seven year rotation. Thus, because the power plant operates at less than full capacity in years one and 30 , only a portion of a full field is in production in years negative seven through negative one and 23 through 29. Although it is likely that biomass production will occur on a continuous basis once several power plants are operating within a reasonable transportation distance, only the operations directly relevant to this plant are included in the analysis.

Table 2: Major Yearly Operations of the Three Subsystems

\begin{tabular}{|l|l|l|l|}
\hline Year & \multicolumn{3}{|c|}{ System Operations } \\
\hline & Feedstock Production & Transportation & Power Plant \\
\hline-7 & $1 / 2$ of a field in production & None & None \\
\hline-6 & $11 \frac{1}{2}$ fields in production & None & None \\
\hline-5 & $2 \frac{1}{2}$ fields in production & None & None \\
\hline-4 & $31 \frac{1}{2}$ fields in production & None & None \\
\hline-3 & $4 \frac{1}{2}$ fields in production & None & None \\
\hline-2 & $5 \frac{1}{2}$ fields in production & Rail car and truck production & $\begin{array}{l}\text { Power plant } \\
\text { construction }\end{array}$ \\
\hline
\end{tabular}




\begin{tabular}{|c|c|c|c|}
\hline \multirow[t]{2}{*}{ Year } & \multicolumn{3}{|c|}{ System Operations } \\
\hline & Feedstock Production & Transportation & Power Plant \\
\hline-1 & $61 / 2$ fields in production & Transport of power plant equipment & $\begin{array}{l}\text { Power plant } \\
\text { construction }\end{array}$ \\
\hline 1 & 7 fields in production & $\begin{array}{l}\text { Transport } 1 / 2 \text { of the biomass required for } \\
\text { operation of the power plant at } 80 \% \text { capacity }\end{array}$ & $\begin{array}{l}\text { Operation at } 50 \% \text { of } \\
80 \% \text { of capacity } \\
\text { ( } 40 \% \text { capacity factor) }\end{array}$ \\
\hline $2-23$ & 7 fields in production & $\begin{array}{l}\text { Transport all of the biomass required for } \\
\text { operation of the power plant at } 80 \% \text { capacity } \\
\text { Truck production and decommissioning of } \\
\text { trucks in years } 7,15 \text {, and } 22\end{array}$ & $\begin{array}{l}\text { Operation at } 80 \% \text { of } \\
\text { capacity }\end{array}$ \\
\hline 24 & $63 / 4$ fields in production & $\begin{array}{l}\text { Transport all of the biomass required for } \\
\text { operation of the power plant at } 80 \% \text { capacity }\end{array}$ & $\begin{array}{l}\text { Operation at } 80 \% \text { of } \\
\text { capacity }\end{array}$ \\
\hline 25 & $53 / 4$ fields in production & $\begin{array}{l}\text { Transport all of the biomass required for } \\
\text { operation of the power plant at } 80 \% \text { capacity }\end{array}$ & $\begin{array}{l}\text { Operation at } 80 \% \text { of } \\
\text { capacity }\end{array}$ \\
\hline 26 & $43 / 4$ fields in production & $\begin{array}{l}\text { Transport all of the biomass required for } \\
\text { operation of the power plant at } 80 \% \text { capacity }\end{array}$ & $\begin{array}{l}\text { Operation at } 80 \% \text { of } \\
\text { capacity }\end{array}$ \\
\hline 27 & $33 / 4$ fields in production & $\begin{array}{l}\text { Transport all of the biomass required for } \\
\text { operation of the power plant at } 80 \% \text { capacity }\end{array}$ & $\begin{array}{l}\text { Operation at } 80 \% \text { of } \\
\text { capacity }\end{array}$ \\
\hline 28 & $23 / 4$ fields in production & $\begin{array}{l}\text { Transport all of the biomass required for } \\
\text { operation of the power plant at } 80 \% \text { capacity }\end{array}$ & $\begin{array}{l}\text { Operation at } 80 \% \text { of } \\
\text { capacity }\end{array}$ \\
\hline 29 & $3 / 4$ of a field in production & $\begin{array}{l}\text { Transport all of the biomass required for } \\
\text { operation of the power plant at } 80 \% \text { capacity }\end{array}$ & $\begin{array}{l}\text { Operation at } 80 \% \text { of } \\
\text { capacity }\end{array}$ \\
\hline 30 & Zero fields in production & $\begin{array}{l}\text { Transport } 75 \% \text { of the biomass required for } \\
\text { operation of the power plant at } 80 \% \text { capacity } \\
\text { Decommission trucks and rail car }\end{array}$ & $\begin{array}{l}\text { Operation at } 75 \% \text { of } \\
80 \% \text { of capacity } \\
(60 \% \text { capacity factor }) \\
\text { Decommission power } \\
\text { plant }\end{array}$ \\
\hline
\end{tabular}

\subsection{Technoeconomic Analysis}

Generally, a process is analyzed based on what it will cost to build and operate, but environmental issues are clearly taking a more prominent role in project decision making. In order to better marry economic and environmental considerations, a technoeconomic analysis and life cycle assessment were conducted on the same process. An economic analysis previously performed for this biomass gasification combined cycle system was updated and a design change was incorporated to recycle a portion of the dryer exhaust gas to the char combustor in order to reduce the amount of VOCs emitted to the atmosphere. The original economic analysis for which the updated results are summarized below can be found in more detail in Craig and Mann (1996). 
The low pressure indirectly-heated gasifier selected for this study was developed at Battelle Columbus Laboratories (BCL) specifically for biomass gasification. Future Energy Resources Corporation (FERCO) now owns the rights to the technology and is participating in its demonstration at the existing McNeil power plant in Burlington, Vermont. A schematic of this gasifier integrated with the combined cycle is shown in Figure 5. The distinctive feature of the BCL/FERCO unit is that unlike direct-fired gasifiers, which use both steam and air, only steam is injected with the biomass to promote gasification. Therefore, the fuel gas has a greater calorific value $\left(12.7 \mathrm{MJ} / \mathrm{m}^{3}, 340 \mathrm{Btu} / \mathrm{scf}\right.$, LHV basis) than that produced by air-blown gasifiers $\left(4.3 \mathrm{MJ} / \mathrm{m}^{3}\right.$, $115 \mathrm{Btu} / \mathrm{scf}, \mathrm{LHV}$ basis). The heat necessary for the endothermic gasification reactions is supplied by sand circulating between a fluidized bed char combustor and the gasification vessel. In addition to acting as the heat source, the sand is the bed material for the gasifier, designed as an entrained fluidized bed reactor. Of the total amount of sand being circulated, $0.5 \%$ is purged to prevent ash build-up in the system. Because this stream is nearly $100 \%$ sand, it is assumed to be used in asphalt production.

The combined cycle investigated is based on the GE MS-6101FA utility gas turbine, an advanced turbine that moves GE's "F" technology (high firing temperature, high efficiency) down to a $70 \mathrm{MW}$ class machine. Gas turbine performance when using biomass-derived fuel gas was estimated based on the operating parameters (air flow, pressure ratio, firing temperature, outlet temperature) of the selected gas turbine (Anderson, 1993, and Gas Turbine World, 1993). A simulation was developed that matches its performance (output, heat rate) on natural gas fuel by "tuning" the efficiency of the various compression and expansion stages as well as adjusting heat losses, cooling air extraction etc. Utilizing these same "tuning" parameters, the resulting turbine model was incorporated, along with the biomass gasifier and cleanup section models, into a simulation of the overall gasification combined cycle plant. The simulation was configured such that the amount of biomass fed to the system was calculated based on the amount of gaseous fuel required by the gas turbine to achieve its design firing temperature. Changes in the gas turbine output and efficiency because of the increased mass flow of the lower energy content gas and the higher fuel gas temperature are thus roughly predicted.

To evaluate the performance of the BIGCC system, a detailed process model was developed in ASPEN Plus ${ }^{\mathrm{TM}}$. The material and energy balance results of the simulation were used to size and cost major pieces of equipment from which the resulting cost of electricity was calculated. The simulation calculates the overall biomass-to-electricity efficiency for the system based on total feed and the net electrical power produced. The major auxiliary equipment items (feed water pumps, boost compressor, blowers, etc.) are explicitly included in the simulation, and their power requirements are subtracted from the gross plant output. A 3\% charge was taken against this preliminary net power (gross minus major equipment) to account for balance of plant electrical power including wood handling and drying. 


\section{Figure 5: Low Pressure Indirect BIGCC Schematic}

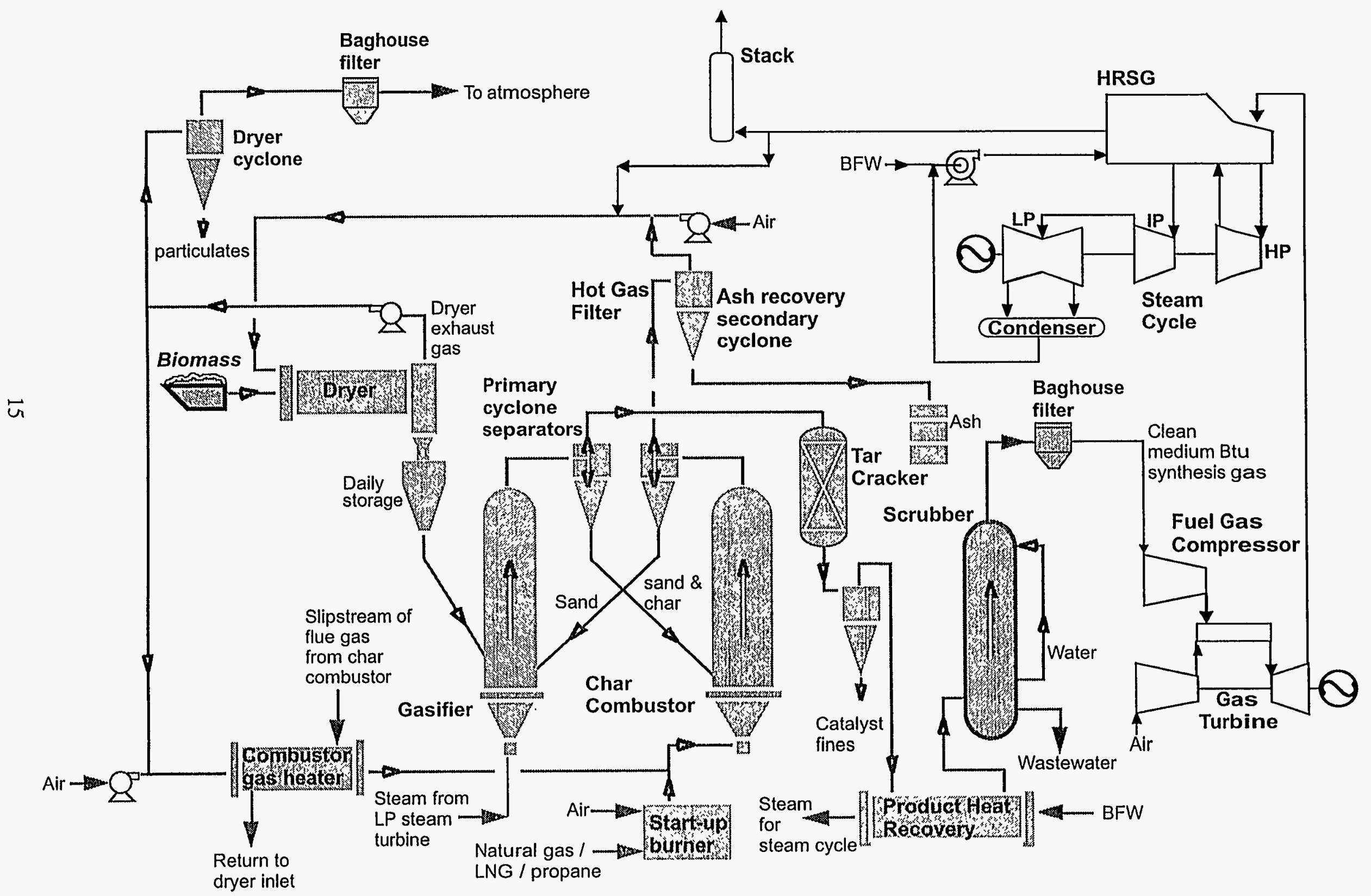




\subsection{Biomass Combined Cycle System Description}

The biomass-based IGCC electric generating plant considered in the economic evaluation consists of the following process sections:

- $\quad$ Feedstock receiving and preparation island

- Truck unloading system

- Wood yard and storage

- Sizing and conveying system

- Dryers

- Live storage area

- Gasification and gas cleaning

- Wood feeding unit

- Gasifier

- Char combustion and air heating

- Primary cyclone

- Tar cracker

- Gas quench

- Particulate removal operation

- $\quad$ Power island

- Gas turbine and generator

- Heat Recovery Steam Generator (HRSG)

- Steam turbine and generator

- Condenser, cooling tower, feed water and blowdown treating unit

\section{- General plant utilities and facilities}

\subsection{Model Description}

The gasifier portion of the ASPEN Plus ${ }^{\mathrm{TM}}$ model was developed using experimental data from BCL $9 \mathrm{Mg} /$ day process development unit (Bain, 1992). Because the gasifier operates at nearly atmospheric pressure (172 $\mathrm{kPa}, 25 \mathrm{psia}$ ), wood from the rotary dryers is fed to the gasifier using an injection screw feeder. Gasification occurs at $825^{\circ} \mathrm{C}\left(1,517^{\circ} \mathrm{F}\right)$, and combustion of the char occurs at $982^{\circ} \mathrm{C}\left(1,800^{\circ} \mathrm{F}\right)$. Fuel gas from the gasifier is cleaned using a tar cracker to reduce the molecular weight of the larger hydrocarbons, and a cyclone separator to remove particulates. A direct water quench is used to remove alkali species and cool the gas to $97^{\circ} \mathrm{C}\left(207^{\circ} \mathrm{F}\right)$ for compression. As an additional safeguard, a baghouse filter is also included to remove any fine particulates that were not removed in the cyclone separator and to ensure that any alkali species that were not removed in the quench are not introduced to the compression and turbine systems. Compression of the fuel gas prior to the gas turbine combustor is accomplished in a five-stage centrifugal compressor with interstage cooling. This compressor increases the pressure from $172 \mathrm{kPa}$ to $2,068 \mathrm{kPa}$ (25 psia to $300 \mathrm{psia}$ ). The maximum interstage temperature is $158^{\circ} \mathrm{C}\left(316^{\circ} \mathrm{F}\right)$, and the interstage coolers reduced the 
temperature of the syngas to $93^{\circ} \mathrm{C}\left(199^{\circ} \mathrm{F}\right)$. This unit operation was optimized at five stages according to the purchased equipment cost and horsepower requirements. After compression, the syngas is heated indirectly to $371^{\circ} \mathrm{C}\left(700^{\circ} \mathrm{F}\right)$ with process heat from the quench and char combustor flue gas.

Gas turbine exhaust is ducted to the heat recovery steam generator (HRSG), which incorporates a superheater, high and low pressure boilers, and economizers. Two percent boiler blowdown is assumed and feedwater heating and deaeration are performed in the HRSG system. All feedwater pumps are motor driven rather than steam turbine driven. In the steam cycle, superheated steam at $538^{\circ} \mathrm{C}$ and $10 \mathrm{MPa}\left(1,000^{\circ} \mathrm{F}, 1,465 \mathrm{psia}\right)$ is expanded in the high pressure turbine. The steam is then combined with steam from the low pressure (LP) boiler, reheated, and introduced into the intermediate pressure (IP) turbine. Exhaust from the IP turbine is passed though the LP turbine. Gasification steam is extracted from the LP exhaust and the remaining steam is condensed at 6,900 $\mathrm{Pa}$ (2 in. $\mathrm{Hg}$ ). Expanded steam quality leaving the low pressure turbine is $90 \%$. Assumed generator efficiency is $98.5 \%$. The exhaust temperature from the HRSG, $140^{\circ} \mathrm{C}\left(284^{\circ} \mathrm{F}\right)$, is sufficiently high to avoid any possible corrosion in the stack and to mitigate steam plume visibility issues.

\subsubsection{Wood Preparation and Drying}

Design of the wood receiving, handling, and drying operations is based on a number of existing studies in this area (Breault and Morgan, 1992, Ebasco Environmental, 1993, and Wiltsee, 1993). The biomass used in the analysis is hybrid poplar; the elemental and property analysis for the biomass is shown in Table 3. Wood chips sized to fit through a two-inch screen are delivered by truck and train to the plant site; the delivered biomass price is assumed to be $\$ 46 / \mathrm{bone}$ dry $\mathrm{Mg}$ (\$42/bone dry ton). The wood is unloaded and moved to the paved three-week storage yard, conveyed to the dryers (two in parallel), and then to the "live" or "day" storage bin from where it is fed to the gasifier. The average amount of biomass fed to the plant at 100\% capacity, as dictated by the fuel requirements of the gas turbine, is 1,334 bone dry $\mathrm{Mg}$ per day (1,470 bone dry tons per day).

Table 3: Biomass Analysis - Ultimate Analysis for Hybrid Poplar

\begin{tabular}{|llllllll|}
\hline Component & Carbon & Oxygen & Hydrogen & Nitrogen & Sulfur & Chlorine & Ash \\
wt \%, dry basis & 50.88 & 41.90 & 6.04 & 0.17 & 0.09 & 0.00 & 0.92 \\
\hline \multicolumn{10}{|c|}{$=50 \%$} \\
\hline
\end{tabular}

The wood dryers are of the co-current rotary drum type. Design conditions selected for the wood drying section result in a moisture content of $11 \%$ by weight. A mixture of ambient air, char combustor flue gas, and a large fraction of the HRSG exhaust gas is used for wood drying. Sufficient ambient air is mixed with the combustion products to reduce the gas temperature to $204^{\circ} \mathrm{C}$ $\left(400^{\circ} \mathrm{F}\right)$ prior to introduction to the dryers. It is believed that this temperature is low enough to avoid the possibility of dryer fires. A slipstream of the dryer exhaust gas at $80^{\circ} \mathrm{C}\left(175^{\circ} \mathrm{F}\right)$, is recycled to the char combustor in order to reduce the amount of VOCs emitted to the atmosphere. This configuration is a change from the original design basis. The trade-off of recirculating a slipstream of the dryer exhaust gas is the cost of an additional blower and its electricity consumption in 
exchange for a reduction in dryer emissions. The remaining gas stream enters the dryer cyclone and then a baghouse to reduce particulate emissions before being emitted to the atmosphere. The temperature level at the baghouse is believed to be sufficiently low to mitigate fire danger. The dried wood exits the dryers at $68^{\circ} \mathrm{C}\left(155^{\circ} \mathrm{F}\right)$ and cools further during final transport to the feed system.

\subsubsection{Gasification}

The product gas composition, calculated by the simulation, is shown in Table 4. The design parameters and operating conditions of the gasifier are shown in Table 5.

Table 4: Gasifier Product Gas Composition, Dry Basis

\begin{tabular}{|lllllllllll|}
\hline Component & $\mathrm{H}_{2}$ & $\mathrm{CO}$ & $\mathrm{CO}_{2}$ & $\mathrm{CH}_{4}$ & $\mathrm{C}_{2} \mathrm{H}_{2}$ & $\mathrm{C}_{2} \mathrm{H}_{4}$ & $\mathrm{C}_{2} \mathrm{H}_{6}$ & Tars & $\mathrm{H}_{2} \mathrm{~S}$ & $\mathrm{NH}_{3}$ \\
Volume \% & 33.68 & 36.35 & 11.34 & 13.33 & 0.30 & 3.89 & 0.39 & 0.34 & 0.07 & 0.32 \\
\hline \multicolumn{1}{|l}{} & & & & & & & \\
\hline $\mathrm{LHV}=12.7 \mathrm{MJ} / \mathrm{m}^{3}(340 \mathrm{Btu} / \mathrm{scf})$ & & & & & & & \\
$\mathrm{HHV}=13.7 \mathrm{MJ} / \mathrm{m}^{3}(368 \mathrm{Btu} / \mathrm{scf})$
\end{tabular}

Table 5: Gasifier Design Parameters and Operating Conditions

\begin{tabular}{|l|l|}
\hline Gasifier temperature & $826^{\circ} \mathrm{C}\left(1519^{\circ} \mathrm{F}\right)$ \\
\hline Gasifier pressure & $0.17 \mathrm{MPa}(25 \mathrm{psia})$ \\
\hline Dried wood feed to gasifier (11\% moisture, $100 \%$ capacity) & $1,498 \mathrm{Mg} /$ day $(1,651 \mathrm{t} /$ day $)$ \\
\hline Dried wood moisture content & $11 \%$ \\
\hline Gasifier internal diameter & $2.93 \mathrm{~m}(9.6 \mathrm{ft})$ \\
\hline Steam / wood ratio (wt/wt, MAF) & 0.45 \\
\hline Sand / wood ratio into gasifier (wt/wt) & 19.5 \\
\hline
\end{tabular}

\subsubsection{Gas Turbine}

The combined cycle investigated is based on the GE MS-6101FA, a utility-scale turbine with a pressure ratio of 14.9. The economic analysis performed showed that the increased gas turbine efficiency over smaller turbines offsets the costs of the higher system size and keeps the feed requirements within what might be available from a dedicated feedstock supply system (DFSS).

Hot $\left(371^{\circ} \mathrm{C}, 700^{\circ} \mathrm{F}\right)$ clean fuel gas is introduced into the gas turbine combustor along with air from the high pressure turbine compressor. The fuel gas produced from the gasifier is well within the projected requirements for combustion of lower energy content gas in gas turbines. The use of a direct quench and humidification produces a fuel gas with higher moisture levels, which helps reduce formation of nitrogen oxides in the combustor and increases the mass flow through the turbine expander. 


\subsubsection{General Plant Requirements}

The plant is assumed to be in close proximity to roads or railroad spurs adequate for delivery of the biomass feedstock. This is likely to be true when a DFSS is employed since the power plant would be sited near the center of the area in which biomass is produced.

In addition to the major process area equipment, a mechanical induced-draft cooling tower is assumed; all necessary pumps for condenser cooling and makeup water needs are included. Balance of plant equipment includes plant water supply and demineralization facilities, firewater system, waste water treating, service and instrument air system, and the electric auxiliary systems. General facilities included are roads, administrative, laboratory and maintenance buildings, potable water and sanitary facilities, lighting, heating and air conditioning, flare, fire water system, startup fuel system, and all necessary computer control systems.

\subsection{Economic Analysis}

The intent of the technoeconomic study (original design - Craig and Mann, 1996) was to evaluate the ultimate potential for application of IGCC technology to biomass-based power systems of large scale $\left(>30 \mathrm{MW}_{\mathrm{e}}\right)$. Therefore, the plant design was assumed to be for mature, " $\mathrm{n}$-plant" systems. The aggressive sparing and redundancies typically utilized for "first-plant" designs and the attendant cost associated with such an approach were thus not applied.

\subsubsection{Economic Analysis Methodology}

The selling price of electricity in 1990 (the base year for the technoeconomic evaluation study) was $\$ 0.047 / \mathrm{kWh}, \$ 0.073 / \mathrm{kWh}$, and $\$ 0.078 / \mathrm{kWh}$ for industrial, commercial, and residential customers, respectively (U.S. Department of Energy, 1994). By calculating the economics of the processes being studied and comparing the results to the prices within the electricity generating market, the potential profitability can be assessed.

The levelized cost of electricity was calculated by setting the net present value of the investment to zero. The method and assumptions that were used to calculate the cost of electricity are based on those described in the EPRI Technical Assessment Guide (TAG) and reflect typical utility financing parameters. Independent power producers or cogenerators would clearly have different analysis criteria. A summary of the economic assumptions is presented in Table 6. 
Table 6: Economic Assumptions

\begin{tabular}{|c|c|c|c|c|c|}
\hline \multicolumn{3}{|c|}{$\begin{array}{l}\text { December, } 1990 \text { dollars } \\
30 \text { year project life } \\
30 \text { year book life } \\
20 \text { year tax life } \\
\text { General plant facilities }=10 \% \text { of process plant cost } \\
\text { Project contingency }=15 \% \text { of plant cost } \\
\text { Two year construction period }\end{array}$} & \multicolumn{3}{|c|}{$\begin{array}{l}\text { Royalties }=0.5 \% \text { of process plant cost } \\
\text { Feedstock cost }=\$ 46 / T \text { ( } \$ 42 / t) \\
\text { Thisty days supply of fuel and consumable materials } \\
\text { Accelerated Cost Recovery System (ACRS) depreciation } \\
\text { Federal and state income tax rate }=41 \% \\
\text { Yearly inflation rate for calculation of current dollar cost }=4 \% \\
\text { Zero investment tax credit }\end{array}$} \\
\hline \multicolumn{2}{|c|}{ Financial Structure } & \multicolumn{2}{|c|}{ Current Dollar } & \multicolumn{2}{|l|}{ Constant Dollar } \\
\hline $\begin{array}{l}\text { Type of } \\
\text { Security }\end{array}$ & $\begin{array}{l}\text { \% of Total } \\
\text { Capital Required }\end{array}$ & $\begin{array}{l}\text { Cost/Interest } \\
\text { rate. \% }\end{array}$ & Return, \% & $\begin{array}{l}\text { Cost/Interest rate, } \\
\%\end{array}$ & Return, \% \\
\hline Debt & 50 & 8.6 & 4.3 & 4.5 & 2.3 \\
\hline $\begin{array}{l}\text { Preferred } \\
\text { Stock }\end{array}$ & 8 & 8.3 & 0.7 & 4.2 & 0.3 \\
\hline $\begin{array}{l}\text { Common } \\
\text { Stock }\end{array}$ & 42 & 14.6 & 6.1 & 10.3 & 4.3 \\
\hline \multicolumn{3}{|c|}{ Discount Rate (before tax. cost of capital) } & 11.1 & & 6.9 \\
\hline
\end{tabular}

\subsubsection{Capital Cost Estimates}

Capital costs for the system were estimated using a combination of capacity-factored and equipmentbased estimates. Capacity-factored estimates utilize the ratio of the capacity (flowrate, heat duty, etc.) of the new equipment to an existing piece of equipment multiplied by the cost of the existing equipment to estimate the cost of the new equipment. A scale-up factor particular to the equipment type was applied to the capacity ratio. The equipment-based estimates were determined from more detailed equipment design calculations based on the process conditions and results of the simulations. All costs were estimated in instantaneous 1990 dollars. Where necessary, costs were corrected to 1990 using the Marshall and Swift or Chemical Engineering equipment cost indices. In part, the base year of 1990 was chosen to facilitate a comparison of the costs with previous studies in this area. A charge of $20 \%$ of the installed cost of the major plant sections was applied to account for all balance of plant (BOP) equipment and facilities. The major equipment costs were multiplied by standard factors to arrive at the total direct cost of the installed equipment. Table 7 lists the factors used to determine total direct cost. These factors are for estimating the capital investment based on the total delivered equipment cost. In the design of the various pieces of process equipment, every effort was made to specify units that were modular and capable of being shop fabricated and shipped by rail. 
Table 7: Factors Used for Calculation of Total Direct Plant Cost

\begin{tabular}{|l|c|}
\hline Plant Cost & \% of delivered equipment cost \\
\hline purchased equipment-delivered & $100 \%$ \\
\hline Installation & $15 \%$ \\
\hline Piping & $45 \%$ \\
\hline Instrumentation & $10 \%$ \\
\hline Buildings and Structures & $10 \%$ \\
\hline Auxiliaries & $25 \%$ \\
\hline Outside Lines & $10 \%$ \\
\hline Total Direct Plant Cost (TDC) & $215 \%$ \\
\hline
\end{tabular}

\subsubsection{Overall System Performance}

Process conditions and system performance for the system examined are summarized in Table 8. Net system output is $113 \mathrm{MW}_{\mathrm{e}}$ at a net system efficiency of $37.2 \%$. This efficiency number is the fraction of the energy in the feedstock to the power plant that is delivered to the grid. Gas turbine output and efficiency based on fuel heating value are greater than those listed in the literature for natural gas fuel. These increases are primarily the result of high fuel gas temperatures and the increased mass flow through the turbine expander (due to lower energy content fuel gas).

Table 8: Process Data Summary and System Performance Results

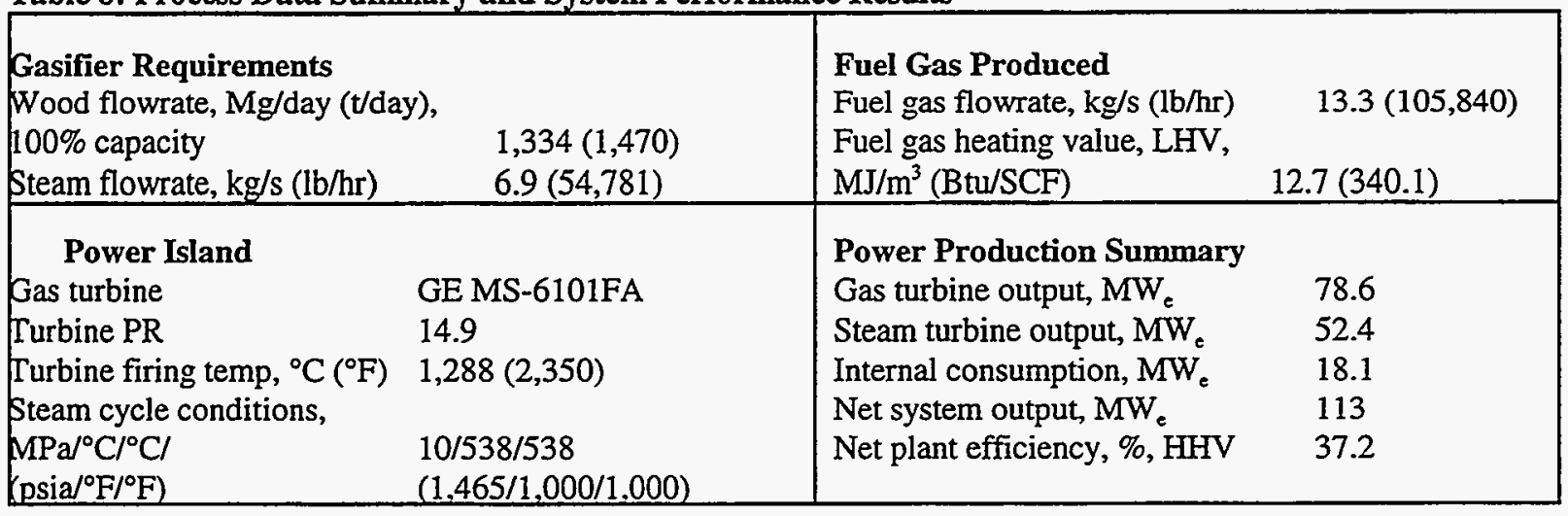

\subsubsection{Economic Analysis Results}

The results of the economic analysis, including the levelized cost of electricity (COE) are shown in Table 9. The economic trade-off of recirculating a slipstream of the dryer exhaust gas is the cost of an additional blower and its electricity consumption in exchange for a reduction in dryer emissions. This design change results in a minimal increase in the selling price of electricity. The updated 
analysis shows the selling price of electricity to be $6.75 ф / \mathrm{kWh}$ in current dollars or $5.25 ф / \mathrm{kWh}$ in constant dollars for the system design described above.

Table 9: Summary of Technoeconomic Analysis Results

\begin{tabular}{|l|l|}
\hline Output (MWe) & 113 \\
\hline Efficiency (HHV) & $37.2 \%$ \\
\hline Capital cost (TCR, \$/kW) & 1,187 \\
\hline Operating cost including fuel (\$1,000/yr) & 25,891 \\
\hline COE ( $₫ / \mathrm{kWh}$, Current $\$)$ & 6.75 \\
\hline COE ( $₫ / \mathrm{kWh}$, Constant $1990 \$)$ & 5.25 \\
\hline
\end{tabular}

\subsection{Description of Process Blocks Studied in the LCA}

The subsystems included in this life cycle assessment are biomass growth, transportation, and electricity production. Refer again to Figures 3 and 4 for the processes within these subsystems. Material and energy flows were quantified for each process block; details about the assumptions and data sources are given in the subsequent sections. To visualize how each upstream process is integrated with others in the system, the screen printouts from the TEAM software are attached as Appendix A. Emissions and energy use of some of the upstream processes were taken from the DEAM database (see section 2.5). The following schematic of the process blocks required for ammonium nitrate production serves as an example of how the total material and energy requirements for an intermediate feedstock were assessed. The data in some of the DEAM databases include the corresponding upstream processes in the block itself (e.g., natural gas production and reforming are included in ammonia production); these blocks are denoted with an asterisk.

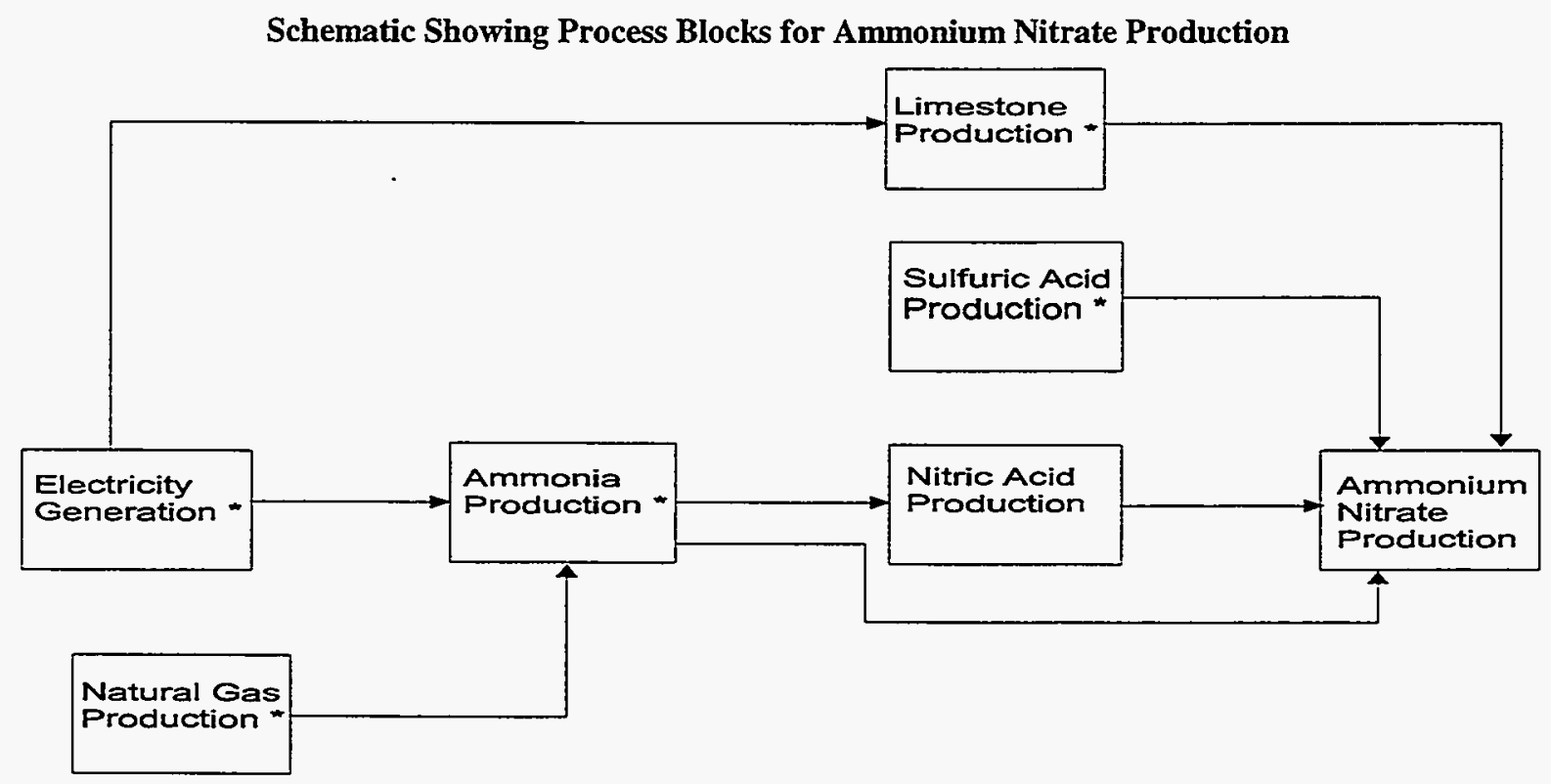

- DEAM database contains information on upstream processes 
The emissions, resources, and energy associated with electricity production for use in upstream process blocks were taken from the DEAM database. The generation mix was that of the midcontinental United States, which according to the National Electric Reliability Council, is composed of $64.7 \%$ coal, $5.1 \%$ lignite, $18.4 \%$ nuclear, $10.3 \%$ hydro, $1.4 \%$ natural gas, and $0.1 \%$ oil; distribution losses are taken at $7.03 \%$. It was assumed that the electricity produced by this biomass power plant will not significantly alter the generation mix given the current size of the market. Natural gas, diesel, and coal production, also taken from the DEAM database, include extraction, processing, and transportation.

\subsection{Base Case Feedstock Production Assumptions}

\subsubsection{Yield Assumptions and Land Requirements}

Biomass for the power plant is assumed to be hybrid poplar, grown as an energy crop specifically for this use. The plantation was assumed to surround the power plant, located in the North-Central Iowa/South-Central Minnesota region of the United States. Defining the site more specifically was originally included in the scope of this project, but deemed unnecessary since site-specific data are generally not available. Rather, average values from test plots were used. A significant amount of data was obtained directly from researchers at Oak Ridge National Laboratory (ORNL). Although published information exists, some from ORNL itself, a notable amount of experience has been gained in recent field trials. ORNL is currently preparing much of the information used for publication.

For the base case analysis, the yield of biomass was assumed to be 13.4 dry $\mathrm{Mg} / \mathrm{ha} / \mathrm{year}$ ( 6 dry t/acre/year) (ORNL, 1996), grown on seven year rotations. Graham et al (1992) report current and expected yields for different regions in the country. For comparison with that being used in the LCA, this information is shown in Table 10. Yield increases were assumed to occur through scientific improvements (such as better breeding) or specific favorable climate conditions, rather than increased fertilizer use. Thus, the amount of fertilizer applied per acre was not varied in relation to yield. The current analysis assumes equal rates of biomass growth for each year that a stand of trees is in production. However, growth rate is almost certainly higher earlier in the rotation (Marland and Marland, 1992), resulting in a declining rate of carbon absorption as the trees mature. When a continuous supply of biomass is needed, the rates average out to those used in this study. However, in the early years of system operation, years negative seven through about negative four, higher growth rates will mean greater removal of $\mathrm{CO}_{2}$ from the atmosphere. Similarly, as the biomass plantation begins to slow its supply to the plant, the net $\mathrm{CO}_{2}$ released will increase. It's important to note that over a seven-year time-frame, though, the average net $\mathrm{CO}_{2}$ emissions will be the same. 
Table 10: Short Rotation Woody Crop Yields

\begin{tabular}{|l|l|l|l|}
\hline Region of U.S. & Current yields & Goal & $\begin{array}{l}\text { Maximum observed } \\
\text { yields }\end{array}$ \\
\hline & \multicolumn{3}{|c|}{ (bone dry Mg/ha/yr) } \\
\hline Northeast & 9.0 & 15.7 & 15.7 \\
\hline South/Southeast & 9.0 & 17.9 & 15.7 \\
\hline Midwest/Lake States & 11.2 & 20.2 & 15.7 \\
\hline Northwest & 15.7 & 29.1 & 43.3 \\
\hline Subtropics & 15.7 & 29.1 & 27.6 \\
\hline
\end{tabular}

The ASPEN Plus ${ }^{\mathrm{TM}}$ simulation gives an average biomass feed requirement of 1,334 bone dry $\mathrm{Mg} /$ day (1,470 bone dry tons/day). If an $80 \%$ capacity factor is assumed, the average feedstock requirement at the plant gate is reduced to $1,067 \mathrm{dry} \mathrm{Mg} /$ day. Later sections will discuss a sensitivity analysis that was performed on operating capacity. Pre- and post-haul losses were based on field trials, and were assumed to be $13.35 \%$ and $4.62 \%$ of the standing yield, respectively (Perlack et al, 1992). Because the biomass is grown on seven year rotations, seven fields will be producing the full feedstock requirements of the plant.

At the base case yield, and including pre- and post-haul losses, the amount of land that will be dedicated to producing biomass for the plant is $44,135.6$ ha. Assuming that only $10 \%$ of the land surrounding the power plant can be used for dedicated feedstock production, the total area around the plant that contains these plantations increases to 441,356 ha. Without choosing a specific site and mapping out the land availability and transportation routes, the average distance to the power plant was determined from an algorithm developed by R. Overend (1981) and now in wide-use in the forest industry. In the calculations, a tortuosity factor of 1.3 , with 1.0 representing line-of-site, was assumed. This results in an average biomass haul distance of $27.6 \mathrm{~km}$.

\subsubsection{Base Case Fertilization Assumptions}

Hybrid poplar requires less fertilization than most traditional row crops such as corn, but field trials indicate that nitrogen, phosphorus, and potassium fertilizers will be necessary. However, short rotation woody crops might be able to absorb the needed nutrients from run-off if they are planted at the periphery of traditional agriculture fields, solving two environmental problems at once. In the base case, nitrogen fertilizer was assumed to be applied at a rate of $100 \mathrm{~kg} / \mathrm{ha}$ nitrate in year four (Tuskan, 1996). Field trials have demonstrated that growth is enhanced by nitrogen fertilization only after the second year, and that by waiting to apply fertilizer until it can be readily absorbed by the root system, movement of nitrate compounds from the plantation and into the surrounding environment can be mitigated. The nitrate was assumed to be supplied as a 50/50 mixture of urea and ammonium nitrate, the two most common forms. The form applied on an actual field will depend on many factors, including regional requirements and what the farmer traditionally uses on other crops. Phosphorus was assumed to be applied as triple superphosphate, at a rate of $22.4 \mathrm{~kg} / \mathrm{ha}$ 
as $\mathrm{P}$ (Tuskan, 1996) in year one of the seven year rotation. Also in the first year, potassium, or potash fertilizer, was applied as $\mathrm{K}_{2} \mathrm{O}$ at a rate of $39.2 \mathrm{~kg} / \mathrm{ha}$ as $\mathrm{K}$. Potassium or potash fertilizers were not required in subsequent years.

Greater than $95 \%$ of commercial nitrogen fertilizers are derived from synthetic ammonia, of which $85 \%$ is dedicated to this use. Ammonium nitrate is produced via a reaction between nitric acid, produced by catalytic oxidation of nitrogen with ammonia, and ammonia produced by catalytic steam reforming of natural gas and subsequent catalytic ammonia synthesis. Limestone and sulfuric acid are used in the prilling process once the ammonium nitrate has been manufactured. The required amounts of ammonia, $60 \%$ nitric acid solution, limestone, and sulfuric acid are $0.21,0.77,0.03$, and $0.01 \mathrm{~kg}$, respectively, per $\mathrm{kg}$ of ammonium nitrate (SRI, 1995). Emissions include ammonia released to the air, ammonia and nitric acid released to water systems, and particulates from prilling operations, in amounts of $0.075,0.018,0.001$, and $0.001 \mathrm{~kg}$ per $\mathrm{kg}$ of product (U.S. EPA, 1995). The process blocks that were included in the LCA for the production of ammonium nitrate were nitric acid production, sulfuric acid production, limestone production, ammonia production, natural gas production, and electricity generation.

Urea is made in a high-temperature and high-pressure reaction between $0.57 \mathrm{~kg}$ of ammonia and 0.75 $\mathrm{kg}$ of carbon dioxide (SRI, 1995). Additionally, $0.022 \mathrm{kWh}$ electrical energy input is required per $\mathrm{kg}$ of product. In the manufacturing process, ammonia and particulates are emitted to the atmosphere at the rate of 0.0122 and $0.0007 \mathrm{~kg}$ per $\mathrm{kg}$ of urea (U.S. EPA, 1995).

Nitrous oxide $\left(\mathrm{N}_{2} \mathrm{O}\right)$ may be produced during nitrification processes at the plantation. Bouwman (1989) estimates that the emissions induced by nitrogen fertilization on cultivated fields is equal to $0.5-2 \%$ of the nitrogen applied. In this assessment, the higher number was assumed for the base case.

The data for granular triple superphosphate production and potash fertilizer production were taken from the DEAM database. The principal emission is $\mathrm{CO}_{2}$ at rates of $0.02 \mathrm{~kg} / \mathrm{kg}$ granular triple superphosphate and $0.002 \mathrm{~kg} / \mathrm{kg} \mathrm{K}_{2} \mathrm{O}$. Additionally, small amounts of hydrocarbons, NOx, and SOx are produced because of fossil fuel combustion for energy generation.

\subsubsection{Base Case Herbicide and Pesticide Use}

From experience gained in hybrid poplar field trials, herbicide application has been found to be necessary for the proper growth and survival of young trees (Tuskan, 1996). For the LCA, both a pre-emergent herbicide (Oust ${ }^{\mathrm{TM}}$ by DuPont) and a post-emergent herbicide (Roundup ${ }^{\mathrm{TM}}$ by Monsanto), were assumed to be used. The application rate of each is $36.5 \mathrm{~cm}^{3}$ of active ingredient per hectare in the first and second years of each crop rotation (Tuskan, 1996). These herbicides will be applied before planting and during crop establishment; no herbicide applications are expected to be required once canopy closure occurs. In addition to the application of chemical herbicides, mowing down emerging weeds and physically removing them from the field may also be practiced. However, this was not assumed in the LCA. 
Because the processes to manufacture Roundup ${ }^{\mathrm{TM}}$ and Oust ${ }^{\mathrm{TM}}$ are proprietary, very little information on material and energy balances is available. Therefore, the emissions associated with their production were not included in the life cycle inventory; however, the quantity used is so low as to be negligible. Turhollow and Perlack (1991), however, report that $418 \mathrm{MJ}$ of energy are required to produce each $\mathrm{kg}$ of active ingredient. Liquid fuel (60\%), natural gas (23\%), and electricity (17\%), are the primary sources. This energy requirement, plus the energy and emissions resulting from extraction, processing, and use of the fossil fuels, were included in the assessment.

Like many other farm chemicals, herbicides are strongly adsorbed onto soil particles. Thus, undesirable movement of herbicides will occur mainly by erosion from the field. However, the ultimate effect on the environment from such movement will depend on the life of the chemicals released and the effect of the resulting species. Riparian filter strips, if used, are likely to remove much of the herbicide in the run-off, especially those substances that degrade quickly (see Sears, 1996, for a more detailed discussion on riparian filter strips). Material safety data sheets (MSDS) for each herbicide were used as a basis for discussing the environmental implications of their use.

Isopropylamine salt of glyphosate, also known as Roundup ${ }^{\mathrm{TM}}$, is manufactured by Monsanto and primarily used as a post-emergent herbicide. It's activity is limited to blocking a plant's ability to manufacture certain amino acids. Direct contact by humans may cause temporary eye irritation and conjunctivitis, while prolonged exposure may cause dermal irritation. Ingestion has produced nausea and vomiting. The MSDS reports the oral LD50 to be $5,400 \mathrm{mg} / \mathrm{kg}$, which Monsanto states to be practically nontoxic. The inhaled LC50 after four hours is $3.18 \mathrm{mg} /$ liter, and reported as slightly toxic. Human testing produced no irritating or sensitizing effects. Roundup ${ }^{\mathrm{TM}}$ was found to be slightly to moderately toxic to marine wildlife. Before Roundup ${ }^{\mathrm{TM}}$ is degraded by microbial activity to $\mathrm{CO}_{2}$ and water, it strongly adheres to soil particles, making movement from the plantation unlikely.

Sulfometruron methyl, manufactured by DuPont under the label Oust ${ }^{\mathrm{TM}}$, is used as a pre- and postemergent weed killer. Oust ${ }^{\mathrm{TM}}$ is soluble to only $10 \mathrm{ppm}$ in water at $\mathrm{pH} 5.5$, and $70 \mathrm{ppm}$ in water at $\mathrm{pH} 7$. In contrast, it is soluble to $2,380 \mathrm{ppm}$ in acetone. Therefore, significant water pollution by Oust ${ }^{\mathrm{TM}}$ is not expected. The hydrolysis rate (i.e., decomposition rate) of Oust ${ }^{\mathrm{TM}}$ in water is shown in Table 11. The half-life of Oust ${ }^{\mathrm{TM}}$ in soil was found to be approximately four weeks in warmer weather conditions in Delaware and North Carolina. Degradation in cold conditions is near zero, and is lower in highly alkaline soils than acidic soils. Additionally, adsorption is higher in acidic soils, while mobility is more likely in alkaline soils.

Table 11: Hydrolysis Rate of Oust ${ }^{\mathrm{TM}}$ Herbicide

\begin{tabular}{|l|l|l|l|l|}
\hline & \multicolumn{5}{|c|}{ Half-life (hours) } \\
\hline Temperature & $\mathrm{pH} \mathrm{2}$ & $\mathrm{pH} \mathrm{5}$ & $\mathrm{pH} \mathrm{7}$ & $\mathrm{pH} \mathrm{9}$ \\
\hline $25^{\circ} \mathrm{C}$ & 100 & 475 & $>1000$ & $>1000$ \\
\hline $45^{\circ} \mathrm{C}$ & 6 & 33 & 150 & 180 \\
\hline
\end{tabular}

Source: Oust MSDS, DuPont 
The LD50 is reported in the MSDS to be greater than $5,000 \mathrm{mg} / \mathrm{kg}$ for male and female rats. Based on skin absorption, the LD50 is greater than $8,000 \mathrm{mg} / \mathrm{kg}$ for male rabbits, and greater than 2,000 for female rabbits. The inhaled LC50 is greater than $5 \mathrm{mg} /$ liter for a four hour exposure. At concentrations of $75 \%$ and less, Oust ${ }^{\mathrm{TM}}$ was not found to be a skin irritant or a permanent eye irritant. Hematological (blood) and biliary and hepatic (liver) effects were observed; histopathological and reproductive effects were not observed. Oust ${ }^{\mathrm{TM}}$ was not found to cause teratogenic or mutagenic effects.

The use of pesticides to control insects and small mammals on hybrid poplar plantations is expected to be unpredictable and sporadic (Tuskan, 1996). The amounts will likely be small if any. Furthermore, alternative methods such as natural barriers and breeding pest resistance into the trees may be able to eliminate pesticide use altogether. For these reasons, use was assumed to be zero, although because the environmental implications of pesticide use are generally serious, further study into this matter is warranted.

\subsubsection{Water Consumption by Biomass Plantation}

All water required by the biomass as it grows was assumed to be supplied by rainfall. Therefore, the resources consumed do not include water depletion at the plantation. Also, emissions and energy use do not reflect any irrigation practices should they be used.

\subsubsection{Biogenic Emissions}

Emissions of biogenic compounds from deciduous trees (hardwoods), including poplars, are mainly isoprene. Coniferous forests, on the other hand, emit mainly monoterpene (including alpha and beta pinene). Little data on biogenic emissions exist for hybrid poplar, and because the region in which the trees are grown can influence the amount and effect of these emissions, the data that do exist may have significant error. Additionally, it should be noted that isoprene emissions vary by season, with little-to-none after leaf-fall, and higher amounts during hot weather periods.

Perlack et al (1992), predicted emissions at five different hypothetical test sites to range between 189 and 1,600 kg/ha/year. However, emissions for four of the five sites are between 305 and 616 $\mathrm{kg} / \mathrm{ha} / \mathrm{year}$, with an average of $476 \mathrm{~kg} / \mathrm{ha} / \mathrm{year}$. This average, because it fit well within the bounds of the site with the greatest variance, was chosen as the base case value. P. Hanson at ORNL is now completing a study that translates other literature values, some of which are based on field trials, into yearly averages. Although this study is not yet published, preliminary data indicate that the range reported by Perlack et al is consistent with other measurements on the low end, but that the high end significantly overstates likely isoprene emissions.

\subsubsection{Transportation of Farm Chemicals}

Fertilizers and herbicides required to grow biomass were transported from their point of production to the plantation. Because the actual location of the plantation was not set for this analysis, the 
transportation was assumed to be $60 \%$ by rail and $40 \%$ by truck over an average distance of $640 \mathrm{~km}$ (Pimentel, 1980). Light fuel oil and diesel are used in the trains and trucks, respectively. As with the analysis of transporting the biomass (discussed in section 4.2), the energy and resource consumption of manufacturing trains and trucks were included in the LCA. The emissions produced and energy used to manufacture the fuels were taken from the DEAM database, of which Appendix $\mathrm{B}$ contains information for several of the database modules. Included are the assumptions used in each deriving each database module and the source(s) where the various data was obtained.

\subsubsection{Plantation Operations}

Energy is consumed and emissions are released for each operation required to plant, grow, and harvest biomass. Table 12 shows the activity and machinery used in each year of the seven year rotation. The materials that were required to manufacture each piece of equipment were calculated based on weight (Morbark, 1993) and ORNL's BioCost software documentation (Walsh, 1996). For simplification, only steel and iron are assumed to be used in farm equipment construction, at $98 \%$ and $2 \%$, respectively, of the total weight.

Table 12: Plantation Operations and Necessary Machinery

\begin{tabular}{|c|c|c|c|}
\hline Year of rotation & Operation & Machinery & $\begin{array}{l}\text { Tractor needed, hp } \\
(\mathrm{kW})\end{array}$ \\
\hline 1 & $\begin{array}{l}\text { Plow } \\
\text { Disk } \\
\text { Plant } \\
\text { Apply herbicide } \\
\text { Apply P and K fertilizers } \\
\text { Cultivate }\end{array}$ & $\begin{array}{l}\text { 6-16" Moldboard plow } \\
\text { 33' Tandem disk } \\
\text { 35' Grain drill } \\
50^{\prime} \text { Boom sprayer } \\
40^{\prime} \text { Fertilizer spreader } \\
\text { 2-36" Row cultivator }\end{array}$ & $\begin{array}{l}180(134) \\
180(134) \\
180(134) \\
60(45) \\
60(45) \\
60(45)\end{array}$ \\
\hline 2 & $\begin{array}{l}\text { Apply herbicide } \\
\text { Cultivate }\end{array}$ & $\begin{array}{l}50 ' \text { Boom sprayer } \\
2-36 " \text { Row cultivator }\end{array}$ & $\begin{array}{l}60(45) \\
60(45) \\
\end{array}$ \\
\hline 3 & No activity & & \\
\hline 4 & Apply nitrogen fertilizers & $40^{\prime}$ Fertilizer spreader & $60(45)$ \\
\hline 5 & No activity & & \\
\hline 6 & No activity & & \\
\hline 7 & $\begin{array}{l}\text { Harvest and bunch } \\
\text { Skid } \\
\text { Chip }\end{array}$ & $\begin{array}{l}\text { Feller buncher head } \\
\text { Skidder } \\
\text { Chipper }\end{array}$ & $\begin{array}{l}100(75) \\
\text { none } \\
\text { none }\end{array}$ \\
\hline
\end{tabular}


The number of hours required for the piece of equipment to cover an acre of land was calculated by the following formula (Walsh, 1996):

$$
\text { Hours/acre }=8.25 /(\mathrm{MS} * \mathrm{MW} * \mathrm{FE})
$$

Equation 1

where $\quad$ MS = the typical operating speed of the machine (miles/hour)

$\mathrm{MW}=$ the operation width of the machine (feet)

$\mathrm{FE}=$ the average field efficiency of the machine (percent)

$8.25=$ conversion factor derived by ORNL

The amount of steel used in manufacturing each machine, per acre of biomass in production, was calculated from the following formula (Walsh, 1996). The emissions and energy used to manufacture this steel, as well as to recycle it at the end of the service life, are part of the DEAM database. For each piece of equipment, such data are incorporated into the analysis in the years that manufacturing and decommissioning occur to reflect the true stressors on the environment.

$$
\text { Steel/acre }=\mathrm{W} * 0.98 / \mathrm{APH} / \mathrm{NH}
$$

Equation 2

where $\quad W=$ the weight of the machine (lb)

$\mathrm{APH}=$ acres per hour, the inverse of that calculated in the previous formula

$0.98=$ the fraction of the total weight that is steel

$\mathrm{NH}=$ average annual use (hours)

The calculation for the amount of iron used per acre is the same as for steel except that 0.02 is the fraction of the total weight that is iron. Table 13 gives the parameters and results of these calculations for machinery complements (those that require a tractor for operation). Similar data for harvesting equipment and tractors are shown in Table 14. 
Table 13: Materials Required for Machinery Complement Construction

\begin{tabular}{|l|l|l|l|l|l|l|l|l|l|}
\hline Complement & $\begin{array}{l}\text { Operating } \\
\text { speed } \\
\text { (miles/hr) }\end{array}$ & $\begin{array}{l}\text { Operation } \\
\text { width (feet) }\end{array}$ & $\begin{array}{l}\text { Average } \\
\text { field } \\
\text { efficiency }\end{array}$ & $\begin{array}{l}\text { Acres per } \\
\text { hour }\end{array}$ & Weight (lb) & $\begin{array}{l}\text { Average } \\
\text { annual use } \\
\text { (hr) }\end{array}$ & $\begin{array}{l}\text { Pounds of } \\
\text { steel per } \\
\text { acre }\end{array}$ & $\begin{array}{l}\text { Assumed } \\
\text { lifetime (hr) }\end{array}$ & $\begin{array}{l}\text { Pounds of } \\
\text { iron per acre }\end{array}$ \\
\hline $\begin{array}{l}\text { 6-16" } \\
\text { Moldboard } \\
\text { plow }\end{array}$ & 4.5 & 10.7 & 85 & 4.9 & 5,000 & 200 & 5.0 & 2,000 & 0.10 \\
\hline $\begin{array}{l}33^{\prime} \text { Tandem } \\
\text { disk }\end{array}$ & 6 & 33 & 80 & 9.6 & 11,190 & 200 & 5.7 & 2,000 & 0.11 \\
\hline $\begin{array}{l}35^{\prime} \text { Grain } \\
\text { drill }\end{array}$ & 5 & 35 & 70 & 14.8 & 8,000 & 120 & 4.4 & 1,200 & 0.09 \\
\hline $\begin{array}{l}50^{\prime} \text { Boom } \\
\text { sprayer }\end{array}$ & 7 & 40 & 70 & 23.8 & 3,000 & 120 & 1.0 & 1,500 & .0 .02 \\
\hline $\begin{array}{l}40^{\prime} \text { Fertilizer } \\
\text { spreader }\end{array}$ & 3 & 50 & 60 & 10.9 & 1,000 & 150 & 0.6 & 1,200 \\
\hline $\begin{array}{l}2-36 " \text { Row } \\
\text { cultivator }\end{array}$ & 6 & 6 & 80 & 3.5 & 250 & 60 & 0.01 \\
\hline
\end{tabular}

Table 14: Materials Required for Harvesting Equipment and Tractor Construction

\begin{tabular}{|l|l|l|l|l|l|l|}
\hline Equipment & Acres/hour & Weight (lb) & Average annual use (hr) & Pounds of steel per acre & Assumed lifetime (hr) & Pounds of iron per acre \\
\hline Feller buncher head & 0.83 & 3,600 & 500 & 8.5 & 2,000 \\
\hline Skidder & 0.11 & 5,000 & 2,000 & 23.0 & 0.17 \\
\hline Chipper & 0.26 & 30,000 & 2,000 & 56.2 & 0.45 \\
\hline 60 hp tractor & 1.43 & 4,800 & 330 & 10.1 & 1000 \\
\hline 100 hp tractor & 0.83 & 11,000 & 500 & 26.1 & 11 & 12,0000 \\
\hline $180 \mathrm{hp}$ tractor & 2.0 & 16,000 & 520 & 14.4 & 12,000 & 0.52 \\
\hline
\end{tabular}


Fossil fuel use in farming operations was calculated by ORNL's BioCost software (Walsh, 1996). Equations 3 and 4 are those that this package uses to calculate the fuel and lubricating oil requirements, in gallons per acre, for farming operations. The oil was assumed to be combusted in the engine since data on the fate of lubricating oil are not available. The fuel and lubricating oil for all farm operations was assumed to be diesel and light fuel oil, respectively.

$$
\begin{array}{ll}
\text { Fuel }=(\mathrm{HP} / 2) * 0.0988 / \mathrm{APH} & \text { Equation } 3 \\
\text { Oil }=0.00573+0.0021 * \mathrm{HP} & \text { Equation } 4
\end{array}
$$

where $\quad \mathrm{HP}=$ the horsepower of the piece of equipment

$0.0988=$ conversion factor derived by ORNL

$\mathrm{APH}=$ acres per hour calculated in previous equations

The annual fuel and oil requirements are shown in Table 15.

\subsubsection{Soil Carbon Sequestration Base Case}

Soil carbon is defined to be non-living organic matter integrated with mineral matter. The soil on which hybrid poplar is grown has the potential to sequester carbon such that the total amount of atmospheric carbon that is absorbed by the biomass is more than that contained in the biomass to the power plant. Unfortunately, the ability of soil to sequester carbon is very site-specific and difficult to measure. Furthermore, very few studies specific to energy crops have been conducted. Thus, the data in the literature are sparse and contradictory, making any statistical analysis infeasible. Hansen (1993) says that there will be a loss in soil carbon with trees in cycles of less than six years, and a gain in older stands, particularly ones that are greater than twelve years old. Most importantly, Hansen also reports that within eight to ten years after the plantation is retired, soil carbon reverts back to pre-plantation levels. Perlack et al (1992), estimated the amount of soil carbon increase to be between 13.4-17.9 Mg/ha over a seven year rotation. Schlamadinger and Marland (1996) reported information from Ranney, Wright, and Mitchell at ORNL that soil carbon will increase by 40.3 $\mathrm{Mg} / \mathrm{ha}$ over a seven year rotation, although this number is generally seen to be a very special case. In 1994, Ranney and Mann reported that soil carbon would increase by approximately $30-40 \mathrm{Mg} / \mathrm{ha}$ over 20-50 years, then come to equilibrium, resulting in only a short-term increase in the net amount of $\mathrm{CO}_{2}$ removed from the atmosphere. More recent research by Grigal and Berguson (forthcoming) found no difference in soil carbon in six to 15 year-old hybrid poplar plantations in Minnesota compared to adjacent row crops or hayland. Additionally, carbon sequestration will vary according to the seasons and tilling practices (Reicosky et al, 1995). Because the actual amount sequestered will be highly site specific, and given that the values in the literature vary so widely and are based on a small number of field trials, it is impossible to say what constitutes a representative value. Therefore, a range of values was incorporated into the sensitivity analysis, with the base case assumption that there will be no net soil carbon gain or loss. 


\begin{tabular}{|c|c|c|c|c|c|c|c|}
\hline \multicolumn{6}{|c|}{ Table 15: Annual Fuel and Oil Requirements for Farming Operations } & \multirow[b]{2}{*}{$\begin{array}{l}\text { Oil } \\
\text { (gal/acre) }\end{array}$} & \multirow[b]{2}{*}{$\begin{array}{l}\text { Oil } \\
\text { Consumed } \\
\text { (gal) }\end{array}$} \\
\hline Year & $\begin{array}{l}\text { Number of } \\
\text { fields in } \\
\text { production }\end{array}$ & $\begin{array}{l}\text { Number of } \\
\text { acres in } \\
\text { production }\end{array}$ & $\begin{array}{l}\text { Number of } \\
\text { hectares in } \\
\text { production }\end{array}$ & $\begin{array}{l}\text { Diesel fuel } \\
\text { (gal/acre) }\end{array}$ & $\begin{array}{l}\text { Diesel fuel } \\
\text { consumed } \\
\text { (gal) }\end{array}$ & & \\
\hline$-7 \mid$ & 0.5 & 5,897 & 2,388 & 0.64 & 3,757 & 0.00 & 10 \\
\hline-6 & 1.5 & 17,692 & 7,163 & 0.97 & 17,212 & 0.00 & 44 \\
\hline $\mid-5$ & 2.5 & 29,487 & 11,938 & 0.97 & 28,687 & 0.00 & 73 \\
\hline$|-4|$ & 3.5 & 41,282 & 16,713 & 0.99 & 40,869 & 0.00 & 104 \\
\hline-3 & 4.5 & 53,077 & 21,488 & 0.99 & 52,546 & 0.00 & 134 \\
\hline-2 & 5.5 & 64,871 & 26,264 & 0.99 & 64,223 & 0.00 & 164 \\
\hline$-1 \mid$ & 6.5 & 76,666 & 31,039 & 10.92 & 837,085 & 0.03 & 2,056 \\
\hline 1 & 7 & 82,564 & 33,427 & 10.92 & 901,476 & 0.03 & 2,214 \\
\hline 21 & 7 & 82,564 & 33,427 & 10.92 & 901,476 & 0.03 & 2,214 \\
\hline 3 & 7 & 82,564 & 33,427 & 10.92 & 901,476 & 0.03 & 2,214 \\
\hline $4 \mid$ & 7 & 82,564 & 33,427 & 10.92 & 901,476 & 0.03 & 2,214 \\
\hline 5 & 7 & 82,564 & 33,427 & 10.92 & 901,476 & 0.03 & 2,214 \\
\hline 6 & 7 & 82,564 & 33,427 & 10.92 & 901,476 & 0.03 & 2,214 \\
\hline 7 & 7 & 82,564 & 33,427 & 10.92 & 901,476 & 0.03 & 2,214 \\
\hline 8 & 7 & 82,564 & 33,427 & 10.92 & 901,476 & 0.03 & 2,214 \\
\hline 9 & 7 & 82,564 & 33,427 & 10.92 & 901,476 & 0.03 & 2,214 \\
\hline 10 & 7 & 82,564 & 33,427 & 10.92 & 901,476 & 0.03 & 2,214 \\
\hline 111 & 7 & 82,564 & 33,427 & 10.92 & 901,476 & 0.03 & 2,214 \\
\hline 12 & 7 & 82,564 & 33,427 & 10.92 & 901,476 & 0.03 & 2,214 \\
\hline 13 & 7 & 82,564 & 33,427 & 10.92 & 901,476 & 0.03 & 2,214 \\
\hline 141 & 7 & 82,564 & 33,427 & 10.92 & 901,476 & 0.03 & 2,214 \\
\hline 15 & 7 & 82,564 & 33,427 & 10.92 & 901,476 & 0.03 & 2,214 \\
\hline 16 & 7 & 82,564 & 33,427 & 10.92 & 901,476 & 0.03 & 2,214 \\
\hline $17 \mid$ & 7 & 82,564 & 33,427 & 10.92 & 901,476 & 0.03 & 2,214 \\
\hline 18 & 7 & 82,564 & 33,427 & 10.92 & 901,476 & 0.03 & 2,214 \\
\hline 19 & 7 & 82,564 & 33,427 & 10.92 & 901,476 & 0.03 & 2,214 \\
\hline 20 & 7 & 82,564 & 33,427 & 10.92 & 901,476 & 0.03 & 2,214 \\
\hline 21 & 7 & 82,564 & 33,427 & 10.92 & 901,476 & 0.03 & 2,214 \\
\hline 22 & 7 & 82,564 & 33,427 & 10.92 & 901,476 & 0.03 & 2,214 \\
\hline 23 & 6.75 & 79,615 & 32,233 & 10.92 & 869,281 & 0.03 & 2,135 \\
\hline 24 & 5.75 & 67,820 & 27,458 & 10.28 & 697,287 & 0.03 & 1,708 \\
\hline 25 & 4.75 & 56,025 & 22,682 & 9.95 & 557,211 & 0.02 & 1,365 \\
\hline 26 & 3.75 & 44,230 & 17,907 & 9.95 & 439,904 & 0.02 & 1,078 \\
\hline 27 & 2.75 & 32,436 & 13,132 & 9.93 & 322,040 & 0.02 & 789 \\
\hline 28 & 1.75 & 20,641 & 8,357 & 9.93 & 204,935 & 0.02 & 502 \\
\hline 29 & 0.75 & 8,846 & 3,581 & 9.93 & 87,829 & 0.02 & 215 \\
\hline 30 & 0 & - & - & - & - & 0.80 & - \\
\hline Averages & & 65,270 & 26,425 & 8.85 & 650,144 & 0.04 & 1,597 \\
\hline
\end{tabular}




\subsection{Base Case Biomass Transportation Assumptions}

Most industries use multiple forms of transportation. The two forms of transportation assumed for this study are trucks and trains. The base case assumes that the majority of the transportation needs will be met using trucks; $70 \%$ of the wood is delivered by trucks and $30 \%$ is delivered by trains. In general, the mix of transportation used to haul the biomass from the fields to the power plant will be site-specific. For the base case, the biomass yield is $13.5 \mathrm{dry} \mathrm{Mg} / \mathrm{ha} / \mathrm{year}$ ( $6 \mathrm{dry}$ tons/acre/year) and the biomass haul losses are assumed to be $4.62 \%$ (Perlack et al, 1992). Using these numbers the amount of as-received wood containing $50 \%$ moisture that is transported to the biomass power plant is $814,282,029 \mathrm{~kg} /$ year for an operating capacity of $80 \%$. The capacity of each truck is $23 \mathrm{Mg}$ ( 25 tons); rail transport is assumed to be by conventional freight trains made up of 85 cars with 17 of the cars carrying $77 \mathrm{Mg}$ (85 tons) of wood each. This results in 25,133 truck deliveries and 186 train deliveries to the plant per year. Although the number of truck deliveries (average of 69 per day) is not outside of the range at current operating facilities, if it is deemed to be more than what a community will accept, the number of train deliveries could be increased.

The inventory assessment for the transportation subsystem includes the energy required and emissions generated for the transportation of chemicals, biomass, and other items by truck and train between the boundaries of the biomass production and power generation subsystems. Any transportation requirements within the boundaries of the biomass production and power generation subsystems are included in the inventory assessment for that subsystem. For the base case, the average distance traveled was calculated to be $27.6 \mathrm{~km}$. This calculation assumes that $10 \%$ of the land around the power generation facility is available for crop production and that the land has a tortuosity factor of 1.3. The trucks and trains use diesel and light fuel oil as the fuel source, respectively. The energy and emissions related to extracting crude oil, distilling it, producing a usable transportation fuel, and distributing it to refueling stations plus the emissions produced during combustion of the fuel were included in the total inventory. These data were taken from the DEAM database, of which some details are shown in Appendix B.

There are several ways to handle the emissions associated with vehicle production and decommissioning. One option would be to evenly distribute the emissions associated with these two processes over the lifetime of the plant. Another option would be to account for the emissions in the year that the vehicles are actually produced and disassembled. The latter option is the way in which the emissions were handled in this life cycle assessment.

Table 16 shows the primary materials used in the production of trucks and trains (Dyncorp, 1995). Steel is the main component for both of these modes of transportation. 
Table 16: Truck and Train Material Requirements

\begin{tabular}{|l|l|l|}
\hline \multirow{2}{*}{ Material } & \multicolumn{2}{|c|}{ Amount required } \\
\cline { 2 - 3 } & $(\mathrm{kg} /$ truck $)$ & $(\mathrm{kg} /$ rail car $)$ \\
\hline steel & 13,789 & 6,713 \\
\hline iron & 272 & \\
\hline aluminum & & 45 \\
\hline
\end{tabular}

The lifetime of a train is considered to be 6.08 million $\mathrm{km}$ (3.78 million miles) (DynCorp, 1995), which is equivalent to 30 years. Therefore, the emissions associated with train construction are taken into account in year one and the rail cars are decommissioned in year 30, the last year of operation. The lifetime of a truck is $540,715 \mathrm{~km}$ (336,000 miles) (DynCorp, 1995; Delucchi, 1993), which is about 7.5 years for this analysis. The truck bodies are shredded or crushed and used as scrap metal in secondary metal production operations.

According to the Motor Vehicle Manufacturers Association (1995), 75\% of the truck and train material content is recycled after disassembly. This fraction of the stressors that are normally produced in manufacturing trains and trucks from virgin materials is taken as a credit in the LCA inventory. These are the emissions and energy consumption avoided because of the recycling process. In balance, the stressors produced in the recycling operations themselves are added to the total life cycle inventory. Landfill emissions, for example, come from diesel oil used in shredding and compacting material that would normally be disposed of were it not for recycling. Another example is the electricity consumed to separate metals and other materials. The metals recovered from the trucks and rail cars displace metals production from both scrap and ore with $50 \%$ of the metals split to each. Displacing metals production from ore results in larger credits than those taken for scrap because of stressors associated with ore extraction and transportation that are not associated with scrap recycle.

\subsection{Base Case Power Plant Construction \& Decommissioning Assumptions}

For this analysis, the plant is being constructed over a two year period with startup at $40 \%$ (50\% of $80 \%$ ) operation in year one. During the years following construction the plant will operate at an $80 \%$ capacity factor. The life of the plant is assumed to be 30 years and during the last year the plant will be in operation $60 \%$ ( $75 \%$ of $80 \%$ ) of the time because of decommissioning in the last quarter of that year.

During construction, emissions of particulate matter will be high due to the activities associated with land preparation, drilling and blasting, ground excavation, earth moving, and construction itself. A large portion of the particulate emissions also result from equipment traffic over temporary roads. The total amount of particulates during construction is equivalent to $2.6 \mathrm{Mg}$ per hectare of site area per month of activity. Wet suppression of the land is used to control particulate emissions from the construction site and road paving will begin in the first year of construction. All of the asphalt 
surfaces are composed of compacted aggregate and an asphalt binder (U.S. EPA, 1995). The primary pollutants of concern from the asphalt paving operations are VOCs. There are two types of asphalts: cutback and emulsified. Cutback asphalts, which have been the primary asphalt used in the past, contain petroleum distillate solvents which are released into the atmosphere during the curing process. Emulsified asphalts rely on water evaporation for curing thus minimizing any hydrocarbon emissions. For this analysis, it is assumed that an emulsified asphalt is used since it is appropriate for almost any type of asphalt application. Particulate and asphalt emissions associated with construction were built into TEAM using data from several literature sources (U.S. EPA, 1995 and Ullman's Encyclopedia of Industrial Chemistry).

Table 17 shows the primary materials used for constructing the power plant (Dyncorp, 1995). Concrete and steel are consumed in the largest quantities.

Table 17: Plant Material Requirements (Base Case)

\begin{tabular}{|l|l|}
\hline Material & Amount required $(\mathrm{kg} / \mathrm{GWh}$ electricity produced) \\
\hline concrete & 22,299 \\
\hline steel & 8,341 \\
\hline aluminum & 65 \\
\hline iron & 97 \\
\hline
\end{tabular}

Because it is the most common type of cement used for structural applications, gray portland cement was assumed for the construction of the plant. The cement manufacturing is divided into the following processes: raw materials acquisition and handling, kiln feed preparation, pyroprocessing, and finished cement grinding (U.S. EPA, 1995). More than 30 raw materials are used in manufacturing cement, most obtained from open-pit quarries or mines. However, some are acquired through underground mines or dredging operations. The raw materials are delivered to the plant and the cement is batched on site. Particulate matter from cement dust and sand aggregate is the primary pollutant generated in this step. These emissions, along with the air emissions and energy requirement from the other processing steps, were input into TEAM from the information contained in the U.S. EPA (1995) reference.

\subsection{Base Case Power Generation Assumptions}

The inventory assessment for the power generation subsystem begins at the plant gate of the power plant and ends with the production of electricity. The boundaries, process configuration, and emissions for the power generation subsystem can be seen in Figure 6 . The primary air emissions were determined using the material and energy balances from the ASPEN Plus ${ }^{\mathrm{TM}}$ simulation. Additional emissions such as particulates and VOCs as well as upstream energy requirements for items such as sand were calculated from estimates in various literature sources and documented studies (Weyerhaeuser et al, 1995 and Boustead and Hancock, 1979). Table 18 gives a summary of the power plant operating emissions which were used in this study. 


\section{Figure 6: General Sources of Power Plant Emissions}

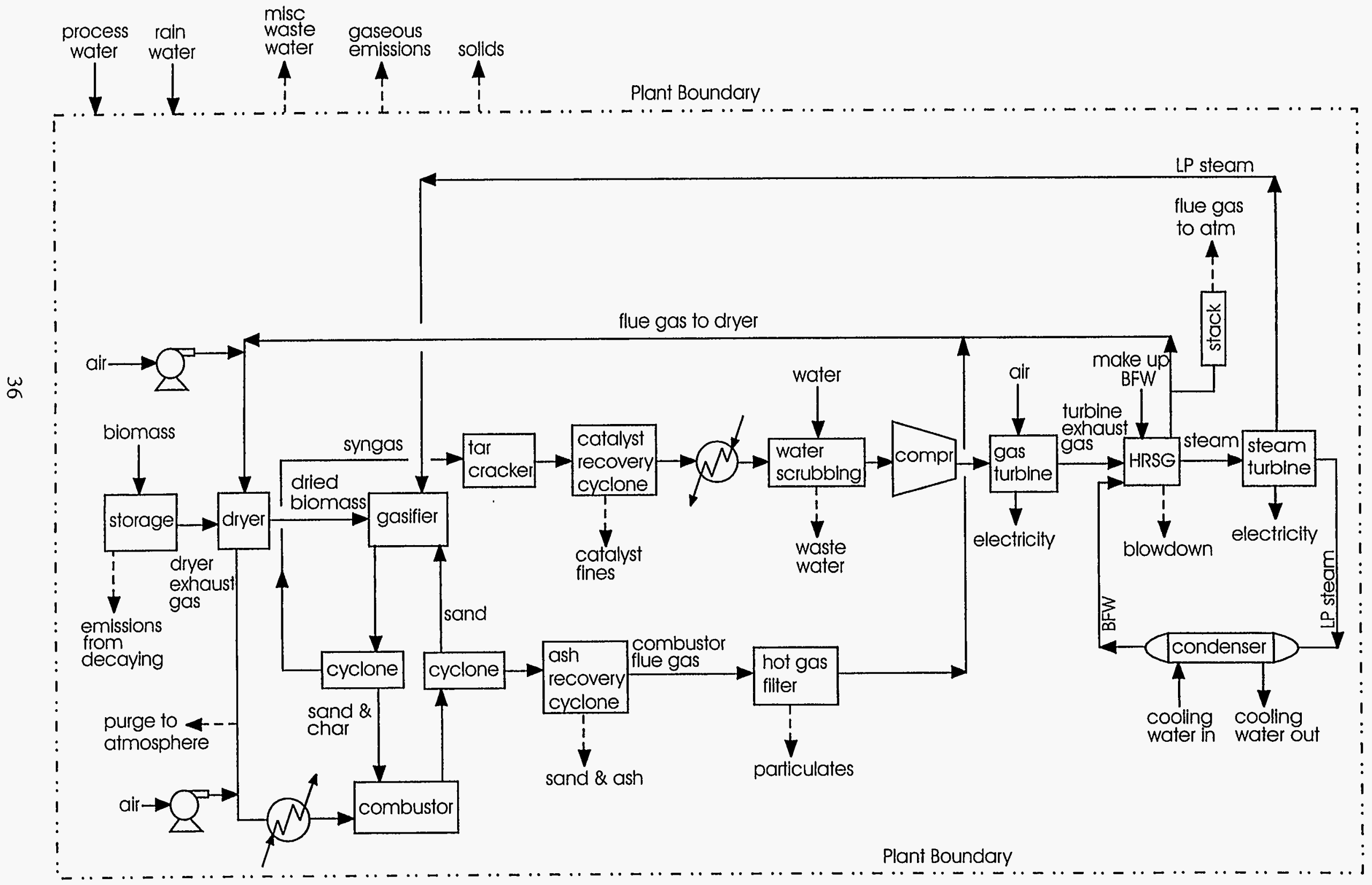


Table 18: Power Plant Operating Emissions (Base Case)

\begin{tabular}{|l|c|c|c|}
\hline Compound & $\begin{array}{c}\text { Emission Amount } \\
(\mathrm{kg} / \mathrm{GWh})\end{array}$ & $\begin{array}{c}\text { Primary Emission } \\
\text { Source }\end{array}$ & Reference \\
\hline $\mathrm{NOx}$ & 479 & gas turbine & ASPEN ${ }^{\odot}$ simulation \\
\hline $\mathrm{SOx}$ & 254 & gas turbine & ASPEN $^{\odot}$ simulation \\
\hline $\mathrm{HC}\left(\right.$ except $\left.\mathrm{CH}_{4}\right)$ & 0.53 & char combustor & Weyerhaeuser 1995 \\
\hline $\mathrm{CO}$ & 0.86 & char combustor & Weyerhaeuser 1995 \\
\hline $\mathrm{CH}_{4}$ & 0.27 & char combustor & Weyerhaeuser 1995 \\
\hline $\mathrm{CO}_{2}$ & 916,224 & char combustor and & ASPEN \\
\hline gar turbine & simulation \\
\hline VOCs & 3.7 & feed prep and dryer & Weyerhaeuser 1995 \\
\hline
\end{tabular}

\subsubsection{Biomass Storage \& Drying}

Biomass is delivered to the plant and unloaded to a paved storage yard. The amount of wood delivered to the plant was set based on the gas turbine design requirements and biomass haul losses. Because biomass is not harvested throughout the year but is required at the plant on a continuous basis, storage is required. It was assumed that the majority of the storage occurs at the plantation, while a three-week supply of chips is maintained at the plant. In order to mitigate degradation and any associated emissions, biomass stored for periods longer than three months is assumed to be kept in whole-tree form (Kropelin, 1997).

Before being gasified, the biomass is dried in a rotary kiln dryer using a mixture of air, the combustor flue gas, and a majority of the flue gas from the HRSG. To reduce wood dust and VOC emissions, a slipstream of the dryer exhaust gas is used as part of the combustion air source for the char combustor (see Figure 5 and 6). This configuration is a change from the original design as reported in Craig and Mann (1996). The ASPEN Plus ${ }^{\mathrm{TM}}$ model demonstrated that it was not feasible to recirculate the total dryer exhaust gas stream to the char combustor because the oxygen content of this stream is only $10 \mathrm{~mol} \%$. Fresh air was added to bring the oxygen content up to $17 \mathrm{~mol} \%$ in accordance with burner manufacture requirements, resulting in a $9 \%$ (weight basis) recycle of the dryer exhaust gas.

It has been hypothesized that more hydrocarbons will be emitted with increased removal of wood moisture content, and that as the wood dries more wood dust will be generated (Adams et al, 1971; Blosser 1986). The wood is dried to $11 \mathrm{wt} \%$ moisture, which should produce lower levels of hydrocarbons and particulate emissions than wood drying for lumber, particleboard, flakeboard, oriented strandboard, hardboard, and veneer. These industries are required to dry the wood to very low moisture concentrations of less than $5 \mathrm{wt} \%$ (Prodehl and Mick, 1973; Adams et al, 1971; Blosser 1986). Many of the concerns associated with wood drying can also be traced back to 
contamination of the wood source. This contamination typically comes from pieces of sawmill machinery, floor sweepings, chemicals, and wood finishes (Schultz and Kitto, 1992). Using wood chips from freshly cut trees instead of waste wood will minimize contamination and corresponding harmful emissions.

\subsubsection{Gasifier/Combustor}

Most of the emissions from the gasification step (including char combustion) were determined by the elemental composition of the wood. All of the nonhydrocarbon emissions, except NOx, will be limited to the amount of sulfur, ash, alkalis, and heavy metals in the feedstock. The elemental sulfur, which is typically less than $0.1 \mathrm{wt} \%$ of the wood on a dry basis, has the potential to form hydrogen sulfide $\left(\mathrm{H}_{2} \mathrm{~S}\right)$ and SOx. Two nitrogen sources, that in the feedstock (on the order of $0.5 \mathrm{wt} \%$ ) and that in the combustion air, have the potential to form NOx in the gasification/combustion step. The initial formation of NOx from the fuel-bound nitrogen will be a function of the amount of excess air, the heat release rate, and the fuel moisture content (Schultz and Kitto, 1992). Thermal NOx is typically formed at high temperatures, in the neighborhood of $1,204^{\circ} \mathrm{C}\left(2,200^{\circ} \mathrm{F}\right)$. Because the char combustor operates at $982^{\circ} \mathrm{C}\left(1,800^{\circ} \mathrm{F}\right)$, the majority of $\mathrm{NOx}$ from the combustor will come from the feedstock. Most thermal NOx from this system will be formed primarily in the gas turbine combustor (discussed in section 4.4.3).

The heat necessary for the endothermic gasification reactions is supplied by sand circulating between the fluidized bed char combustor and the gasification vessel. Although sand is sometimes used in its raw state, most sand is processed prior to use. For this study, the basic operations involved are assumed to be mining, screening, crushing, and washing. Sand is typically mined under wet conditions by open pit excavation or by dredging, and emissions are primarily particulate matter. Many industrial sand facilities use control devices such as cyclones, wet scrubbers, venturi scrubbers, and fabric filters in an effort to minimize particulate emissions.

The products of the gasification step are synthesis gas, char, and ash. The product gas exits the gasifier overhead while greater than $99.5 \%$ of the char and ash are captured with the sand and circulated back to the combustor. The combustor flue gas is sent through a recovery cyclone to remove any residual sand and ash that are carried overhead prior to being sent to the atmosphere. Even though the solids captured in the cyclone are mainly sand, the ash content includes trace amounts of alkalis and heavy metals. The amount of metals in the biomass will depend on the growth environment (Tillman and Prinzing, 1994; Golam et al, 1993). Generally, high heavy metal concentrations in biomass ash have been traced to combustion sources where non-wood wastes are mixed with "clean" wood and then burned (Tillman and Prinzing, 1994; McGinnis et al, 1995). Heavy metal content in the ash is assumed to be negligible because only clean wood from the plantation will be used and because the amounts that might be present are so small they will not affect the end use of the sand and ash mixture.

There has been much speculation regarding uses for biomass ash. It has the potential to be used as a clarifying agent in water treatment, as a wastewater adsorbent, as a liquid waste adsorbent, as a 
hazardous waste solidification agent, as a lightweight fill for roadways, parking areas, and structures, as an asphalt mineral filler, or as a mine spoil amendment (Fehrs and Donovan, 1993). The most sought after use is to landspread the ash on farms in the hopes of utilizing its nutrient mineral content. Because the stream from this system is nearly $100 \%$ sand, however, it is likely that these means of disposal would not be feasible. For this analysis, the sand and ash mixture from the cyclones is assumed to be used in asphalt production for roads, as is the plan for the demonstration facility at the McNeil power plant in Burlington, Vermont. The appropriate credits and stressors for using this material instead of virgin material in asphalt production are taken in this LCA.

\subsubsection{Gas Turbine and HRSG}

The gas turbine emissions consist of NOx, SOx, $\mathrm{CO}, \mathrm{CO}_{2}$, unburned hydrocarbons, VOCs, and particulates. The sulfur and nitrogen compounds contained in the biomass-derived synthesis gas are converted to SOX and NOx in the gas turbine combustor. As discussed earlier in the gasifier/combustor section, fuel-bound NOx cannot be completely eliminated with existing emissions control technology, and because the gas turbine firing temperature is $1,288^{\circ} \mathrm{C}\left(2,350^{\circ} \mathrm{F}\right)$, thermal NOx will be generated. No special emissions-control technologies were assumed in the design of this plant. Therefore, the NOx reported represents a conservative case. For the base case, it was assumed that all of the sulfur and all of the nitrogen contained in the biomass was converted to SOX and NOx, respectively. A sensitivity analysis was performed to account for the possible formation of thermal NOx. Additionally, there will be unburned hydrocarbons and VOCs at the parts-permillion level.

The stack is located on the exhaust from the HRSG. A large portion of the flue gas exiting the HRSG is used to dry the biomass. Therefore, the gas released to the atmosphere is a combination of dryer and gas turbine combustion emissions. Wastewater is also produced from the boiler blowdown, and sent to the wastewater treatment step to be processed into discharge-quality water.

\subsubsection{Water Requirements \& Treatment}

The water requirements for the plant include recirculated quench water, boiler blowdown, cooling water, and miscellaneous water such as utility, potable, and fire water. Once used, water is collected and treated in a wastewater treatment step to produce an effluent that can be reused within the plant or discharged without causing serious environmental impacts.

Prior to compression, the synthesis gas is cooled through heat exchange and water scrubbing. The scrubbing condenses any residual tars that remain after the synthesis gas has passed through the tar cracker. The quantity and composition of the tars depends on the type of gasifier and the operating conditions. The tars that are expected from the BCL/FERCO gasifier consist of more thermally labile "secondary tar" components such as phenol, styrene, and toluene (Gebhard et al, 1994). The wastewater may also contain ash, char, or sand that were not removed in the gasifier cyclone, tars not converted in the tar cracker, and a small quantity of tar cracker catalyst fines. Any carryover of particulates is expected to be in the parts-per-million range. Water from the scrubbing step is sent 
to a separation tank, where insoluble tars are skimmed off of the water and fed back to the char combustor. A portion of the remaining water is used to rehumidify the synthesis gas prior to combustion in the gas turbine. This reduces the amount of water that must be treated and increases the power output from the plant. The remaining water is then treated in the wastewater treatment step.

Physical, chemical, and biological processes are the possible options for treating the wastewater streams. Further defined, physical operations are used to remove floatable and settleable solids, biological and chemical processes are used to remove most of the organic matter in the wastewater, and tertiary systems are used to remove any process constituents that are not taken out in secondary treatment. A combination of each of these was assumed to be used in the power plant. The concentration of organic chemicals from the power plant is anticipated to be low enough that secondary biological treatment will not be necessary, only primary treatment for solids removal. The wastewater is collected through a series of drains, trenches, and sumps that are connected to a main line. Collection systems such as this are generally open to the atmosphere, allowing some VOCs to be emitted. Many factors affect the rate of volatilization of organic compounds from the wastewater, including water surface area, temperature, turbulence, and concentration of organics, to name a few. Determining the rate of volatilization of each organic compound was not done for this study; thus, VOC emissions from wastewater were assumed to be zero.

\subsection{Base Case Results by Impact Category}

Although the material and energy balances for each of the three subsystems (biomass production, transportation, and electricity generation) were examined for each year of production, the resulting impacts were averaged over the life of the system to examine the relative percent of emissions from each. The average amount of emissions produced, resources consumed, and energy used by each of the subsystems per unit of energy delivered by the power plant can be seen in Tables 19 through 23 . It should be noted that only the stressors that were of significant quantity are reported in these tables. Furthermore, these numbers appear to be definitive, while if data for a particular stressor were not available for all blocks, total stressors are being reported as lower than they actually are. The absence of data is specifically spelled out in this report.

In years negative seven through negative three all of the resources, emissions, and energy are associated with feedstock production. As expected, there is a yearly increase as the number of fields in production increases by one each year. The stressors then tend to be level in the positive years even with the construction and decommissioning activities associated with the farm equipment and truck transportation. Finally, a gradual decrease is seen, starting in year 23 when biomass production tapers off, leading up to a rapid decrease in impacts during final decommissioning. A majority of the resources, emissions, and energy are higher in years negative one and negative two due to the activities associated with plant construction. 
Table 19: Average Air Emissions per kWh of Net Electricity Produced

$\%$ of Total in

$\%$ of Total in this Table

$\%$ of Total in this Table Except CO2

this Table (a) Aldehydes

(a) Ammonia (NH3)

(a) Carbon Dioxide (CO2)

(a) Carbon Monoxide (CO)

(a) Chlorides (Cl-)

(a) Fluorides ( $F$-)

(a) Non-methane hydrocarbons (including VOCs)

(a) Hydrogen Chloride ( $\mathrm{HCl}$ )

(a) Hydrogen Fluoride (HF)

(a) Hydrogen Sulfide ( $\mathrm{H} 2 \mathrm{~S})$

(a) Metals (unspecified)

(a) Methane (CH4)

(a) Nitrogen Oxides (NOx as NO2)

(a) Nitrous Oxide (N2O)

(a) Organic Matter (unspecified)

$\pm$

(a) Particulates (unspecified)

(a) Sulfur Oxides (SOx as SO2)

(a) Tars (unspecified)

isoprene
$0.0 \%$

$0.1 \%$

$66.7 \%$

$0.1 \%$

$0.0 \%$

$0.0 \%$

$0.9 \%$

$0.0 \%$

$0.0 \%$

$0.0 \%$

$0.0 \%$

$0.0 \%$

$1.0 \%$

$0.0 \%$

$0.0 \%$

$0.1 \%$

$0.4 \%$

$0.0 \%$

$30.8 \%$

Total ( $\mathrm{g} / \mathrm{kWh})$ Feedstock

$\%$ of Total from $\%$ of Total from $\%$ of Total from

Transportation Power Plant

$1.68 \mathrm{E}-04$
$3.52 \mathrm{E}-02$
$4.59 \mathrm{E}+01$
$8.30 \mathrm{E}-02$
$6.60 \mathrm{E}-07$
$8.08 \mathrm{E}-06$
$5.95 \mathrm{E}-01$
$2.05 \mathrm{E}-06$
$3.81 \mathrm{E}-07$
$2.21 \mathrm{E}-08$
$2.53 \mathrm{E}-09$
$5.07 \mathrm{E}-03$
$6.86 \mathrm{E}-01$
$9.54 \mathrm{E}-03$
$1.06 \mathrm{E}-03$
$4.16 \mathrm{E}-02$
$3.02 \mathrm{E}-01$
$7.69 \mathrm{E}-07$
$2.12 \mathrm{E}+01$

$78.7 \%$

$99.9 \%$

$61.8 \%$

$80.9 \%$

$13.9 \%$

$97.2 \%$

$11.0 \%$

$11.6 \%$

$56.7 \%$

$56.6 \%$

$53.2 \%$

$88.9 \%$

$24.3 \%$

$95.8 \%$

$80.2 \%$

$56.4 \%$

$10.6 \%$

$56.2 \%$

$0.0 \%$

$92.3 \%$

$100.0 \%$ 
Table 20: Average Water Emissions per $\mathrm{kWh}$ of Net Electricity Produced

(w) Acids $(\mathrm{H}+)$

(w) Ammonia (NH4+)

(w) Ammonia ( $\mathrm{NH} 4+, \mathrm{NH} 3$, as $\mathrm{N})$

(w) BOD5 (Biochemical Oxygen Demand)

(w) Chlorides (Cl-)

(w) COD (Chemical Oxygen Demand)

(w) Cyanides (CN-)

(w) Dissolved Matter (unspecified)

(w) Fluorides (F-)

(w) Hydrocarbons

(w) Inorganic Dissolved Matter (unspecified)

(w) Iron $(\mathrm{Fe}++, \mathrm{Fe}+$ +)

(w) Metals (unspecified)

(w) Nitrates (NO3-)

(w) Nitric acid

(w) Nitrogenous Matter (unspecified, as N)

(w) Oils

A $\quad(w)$ Organic Dissolved Matter (unspecified)

(w) Phenol (C6H6O)

(w) Sodium ( $\mathrm{Na}+$ )

(w) Sulfates (SO4--)

(w) Sulfides (S--)

(w) Suspended Matter (unspecified)

(w) Tars (unspecified)

(w) Water: Chemically Polluted
$\%$ of Total in this Total Table ( $\mathrm{g} / \mathrm{kWh})$

$12.2 \%$

$0.0 \%$

$0.5 \%$

$0.0 \%$

$1.5 \%$

$0.0 \%$

$83.1 \%$

$0.0 \%$

$0.0 \%$

$0.0 \%$

$0.0 \%$

$0.0 \%$

$0.0 \%$

$0.7 \%$

$0.0 \%$

$1.6 \%$

$0.0 \%$

$0.0 \%$

$0.0 \%$

$0.0 \%$

$0.0 \%$

$0.4 \%$

$0.0 \%$

$0.0 \%$
1.36E-05

$6.92 \mathrm{E}-06$

3.05E-04

4.90E-06

9.12E-04

4.37E-08

5.09E-02

6.74E-06

5.22E-08

1.11E-06

1.56E-09

6.73E-07

1.91E-07

4.13E-04

2.21E-08

$9.80 \mathrm{E}-04$

4.41E-08

1.33E-07

8.08E-07

8.13E-07

8.73E-08

2.40E-04

1.10E-08

3.80E-08
$\%$ of Total from \% of Total from \% of Total from Feedstock Transportation Power Plant

\begin{tabular}{rrr}
$99.3 \%$ & $0.1 \%$ & $0.6 \%$ \\
$100.0 \%$ & $0.0 \%$ & $0.0 \%$ \\
$90.8 \%$ & $1.4 \%$ & $7.8 \%$ \\
$98.4 \%$ & $1.5 \%$ & $0.1 \%$ \\
$30.7 \%$ & $3.8 \%$ & $65.5 \%$ \\
$98.3 \%$ & $1.5 \%$ & $0.2 \%$ \\
$84.3 \%$ & $2.8 \%$ & $13.0 \%$ \\
$79.2 \%$ & $18.6 \%$ & $2.2 \%$ \\
$80.7 \%$ & $2.9 \%$ & $16.4 \%$ \\
$100.0 \%$ & $0.0 \%$ & $0.0 \%$ \\
$56.4 \%$ & $5.4 \%$ & $38.2 \%$ \\
$55.4 \%$ & $3.6 \%$ & $41.0 \%$ \\
$56.2 \%$ & $5.4 \%$ & $38.5 \%$ \\
$55.4 \%$ & $3.6 \%$ & $41.0 \%$ \\
$100.0 \%$ & $0.0 \%$ & $0.0 \%$ \\
$56.6 \%$ & $5.4 \%$ & $38.0 \%$ \\
$75.8 \%$ & $13.9 \%$ & $10.3 \%$ \\
$56.6 \%$ & $5.4 \%$ & $38.0 \%$ \\
$83.8 \%$ & $2.8 \%$ & $13.4 \%$ \\
$34.2 \%$ & $3.7 \%$ & $62.0 \%$ \\
$35.4 \%$ & $3.7 \%$ & $60.9 \%$ \\
$84.3 \%$ & $2.8 \%$ & $13.0 \%$ \\
$71.8 \%$ & $5.7 \%$ & $22.5 \%$ \\
$56.2 \%$ & $5.4 \%$ & $38.4 \%$ \\
$18.1 \%$ & $2.5 \%$ & $79.4 \%$ \\
\hline
\end{tabular}

Table 21: Average Energy Requirements per kWh of Net Electricity Produced

\begin{tabular}{|c|c|c|c|c|}
\hline & Total (MJ/kWh) & $\begin{array}{l}\% \text { of Total } \\
\text { from } \\
\text { Feedstock }\end{array}$ & $\begin{array}{l}\% \text { of Total from } \\
\text { Transportation }\end{array}$ & $\begin{array}{c}\% \text { of Total from } \\
\text { Power Plant }\end{array}$ \\
\hline & 0.226 & $76.9 \%$ & $15.8 \%$ & $7.3 \%$ \\
\hline Electricity & 0.003906417 & $69.6 \%$ & $6.4 \%$ & $24.0 \%$ \\
\hline Total Energy Consumed by System & 0.230571081 & $76.8 \%$ & $15.6 \%$ & $7.6 \%$ \\
\hline
\end{tabular}

NOTE: The electricity produced and consumed by the power plant is not included in this table.

The power plant energy and electricity requirements are from upstream processes, construction, and decommissioning. 
Table 22: Average Resource Consumption per kWh of Net Electricity Produced

\begin{tabular}{|c|c|c|c|c|c|c|}
\hline & $\begin{array}{c}\% \text { of Total in this } \\
\text { Table }\end{array}$ & $\begin{array}{c}\% \text { of Total in } \\
\text { this Table } \\
\text { Excluding } \\
\text { Water }\end{array}$ & Total (g/kWh) & $\begin{array}{l}\% \text { of Total from } \\
\text { Feedstock }\end{array}$ & $\begin{array}{l}\% \text { of Total from } \\
\text { Transportation }\end{array}$ & $\begin{array}{l}\% \text { of Total from } \\
\text { Power Plant }\end{array}$ \\
\hline (r) Bauxite (Al2O3, ore) & $0.0 \%$ & $0.1 \%$ & 0.00 & $30.1 \%$ & $3.8 \%$ & $66.2 \%$ \\
\hline (r) Clay (in ground) & $0.0 \%$ & $0.0 \%$ & 0.00 & $56.6 \%$ & $5.4 \%$ & $38.0 \%$ \\
\hline (r) Coal (in ground) & $0.1 \%$ & $11.6 \%$ & 0.78 & $67.2 \%$ & $3.9 \%$ & $28.9 \%$ \\
\hline (r) Iron (Fe, ore) & $0.1 \%$ & $8.6 \%$ & 0.58 & $84.3 \%$ & $2.8 \%$ & $13.0 \%$ \\
\hline (r) Limestone (CaCO3, in ground) & $0.0 \%$ & $1.1 \%$ & 0.07 & $87.1 \%$ & $2.3 \%$ & $10.7 \%$ \\
\hline (r) Natural Gas (in ground) & $0.0 \%$ & $3.6 \%$ & 0.24 & $95.2 \%$ & $1.7 \%$ & $3.1 \%$ \\
\hline (r) Oil (in ground) & $0.5 \%$ & $65.0 \%$ & 4.37 & $79.2 \%$ & $18.5 \%$ & $2.3 \%$ \\
\hline (r) Phosphate Rock (in ground) & $0.0 \%$ & $0.9 \%$ & 0.06 & $100.0 \%$ & $0.0 \%$ & $0.0 \%$ \\
\hline (r) Potash (K2O, in ground) & $0.0 \%$ & $0.2 \%$ & 0.02 & $100.0 \%$ & $0.0 \%$ & $0.0 \%$ \\
\hline (r) Sand (in ground) & $0.0 \%$ & $0.0 \%$ & 0.00 & $30.1 \%$ & $3.8 \%$ & $66.2 \%$ \\
\hline (r) Sodium Chloride & $0.0 \%$ & $0.0 \%$ & 0.00 & $33.0 \%$ & $3.9 \%$ & $63.1 \%$ \\
\hline (r) Uranium (U, ore) & $0.0 \%$ & $0.0 \%$ & 0.00 & $55.3 \%$ & $3.6 \%$ & $41.1 \%$ \\
\hline Aluminum Scrap & $0.0 \%$ & $0.0 \%$ & 0.00 & $30.1 \%$ & $3.8 \%$ & $66.2 \%$ \\
\hline Iron Scrap & $0.1 \%$ & $9.0 \%$ & 0.60 & $84.0 \%$ & $2.8 \%$ & $13.2 \%$ \\
\hline Lubricant & $0.0 \%$ & $0.1 \%$ & 0.00 & $67.9 \%$ & $4.6 \%$ & $27.5 \%$ \\
\hline Trinitrotoluene & $0.0 \%$ & $0.0 \%$ & 0.00 & $30.1 \%$ & $3.8 \%$ & $66.2 \%$ \\
\hline Water Used (total) & $94.9 \%$ & & 890.83 & $3.9 \%$ & $0.1 \%$ & $96.0 \%$ \\
\hline Water: Unspecified Origin & $4.4 \%$ & & 41.45 & $83.5 \%$ & $3.2 \%$ & $13.3 \%$ \\
\hline
\end{tabular}

Table 23: Average Solid Waste Generation per kWh of Net Electricity Produced

\begin{tabular}{|c|c|c|c|c|c|}
\hline & $\%$ of total Waste & $\begin{array}{l}\text { Total } \\
(\mathrm{g} / \mathrm{kWh})\end{array}$ & $\begin{array}{l}\% \text { of Total from } \\
\text { Feedstock }\end{array}$ & $\begin{array}{l}\% \text { of Total from } \\
\text { Transportation }\end{array}$ & $\begin{array}{l}\% \text { of Total from } \\
\text { Power Plant }\end{array}$ \\
\hline Waste (hazardous) & $0.0 \%$ & 0.00 & $40.7 \%$ & $4.4 \%$ & $54.9 \%$ \\
\hline Waste (municipal and industrial) & $24.5 \%$ & 0.15 & $32.6 \%$ & $8.7 \%$ & $58.7 \%$ \\
\hline Waste (unspecified) & $75.5 \%$ & 0.48 & $68.4 \%$ & $3.6 \%$ & $28.0 \%$ \\
\hline Waste (total) & $100.0 \%$ & 0.63 & $59.6 \%$ & $4.9 \%$ & $35.5 \%$ \\
\hline
\end{tabular}




\subsection{Air Emissions}

Table 19 shows the majority of air emissions tracked in the LCA, averaged over the life of the system. Significant air emissions were found to come from all three subsystems, but primarily from the feedstock production and power plant subsystems. In terms of the total amount (not impact on the environment), $\mathrm{CO}_{2}$ is emitted in the greatest quantity. Allocating the amount of atmospheric $\mathrm{CO}_{2}$ absorbed by the biomass to the power plant, the percentages of total $\mathrm{CO}_{2}$ emissions from the feedstock, transportation, and power plant subsystems, respectively, are $62 \%, 12 \%$, and $26 \%$. The $\mathrm{CO}_{2}$ from the power plant subsystem is due to plant construction and decommissioning.

The second largest air emission is isoprene, the compound used to model biogenic emissions from the trees. Yearly isoprene emissions are shown in Figure 7. As expected, they were found to increase by one-seventh each year in the negative years, and decrease by one-seventh each year in years 23 through 30 when biomass production tapers off. It should be noted that simply because isoprene was emitted in the second greatest quantity, its total amount released and impacts are not necessarily large or significant. Further studies of actual releases and impacts should be done.

NOx and non-methane hydrocarbon (NMHC) emissions (including VOCs) are the next highestreleased air emissions, followed by SOx. The quantities of all air emissions released from transportation are lower than from the rest of the system; the power plant produces the majority of SOx, NOx, and NMHC emissions. The majority of air emissions, besides $\mathrm{CO}_{2}$ and isoprene, produced in the feedstock production section are typical of those from diesel-fueled farm equipment (e.g., methane, hydrocarbons, carbon monoxide, particulates); the total amount of these emissions is small in comparison to other emissions from the power plant. It should be noted that because of a lack of data, biomass decomposition during storage and transport was assumed to produce $\mathrm{CO}_{2}$ rather than methane. The species released in a real situation will depend on the conditions that the biomass is subjected to as it decomposes. If it is kept in mostly aerobic environments, as is likely, little-to-no methane will be produced.

There are five major gaseous forms of nitrogen expected to be released from the biomass-toelectricity system. These include diatomic nitrogen $\left(\mathrm{N}_{2}\right)$, ammonia $\left(\mathrm{NH}_{3}\right)$, nitrous oxide $\left(\mathrm{N}_{2} \mathrm{O}\right)$, nitric oxide (NO), and nitrogen dioxide $\left(\mathrm{NO}_{2}\right) . \mathrm{N}_{2}$ was not included in the mass balances for this LCA; therefore, the other nitrogen compounds shown in Table 19 make up a much larger portion of total gaseous emissions than would really be the case. Because both participate in photochemical reactions, $\mathrm{NO}$ and $\mathrm{NO}_{2}$ are collectively designated as NOx.

Three air emissions that are generally believed to have the potential to contribute to global warming were found to be emitted from this system. They are $\mathrm{CO}_{2}, \mathrm{CH}_{4}$, and $\mathrm{N}_{2} \mathrm{O}$. To determine the total global warming potential (GWP) from these compounds, weighting factors determined by the Intergovernmental Panel on Climate Change (IPCC) were applied. The GWP of a gas reflects its cumulative radiative capacity over a specified period of time. The numbers developed by the IPCC are based on a 100 year time frame. The recommended values, expressed as the GWP of a gas 


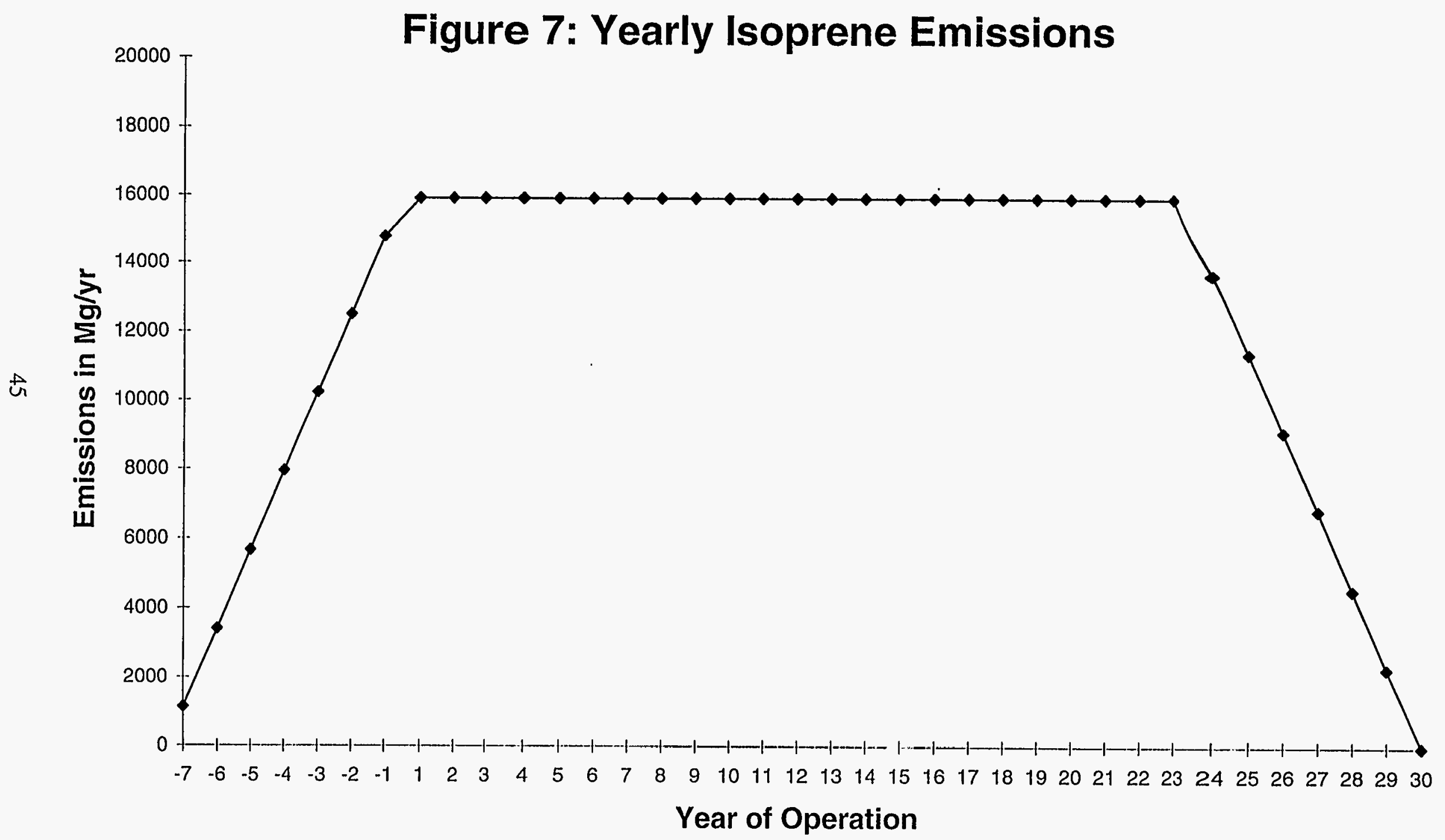


relative to $\mathrm{CO}_{2}$ on a mass basis, were 21 for methane and 310 for nitrous oxide (United Nations, 1996). $\mathrm{CO}_{2}, \mathrm{CH}_{4}$, and $\mathrm{N}_{2} \mathrm{O}$ were found to be emitted from the system at rates of $45.9,0.005$, and $0.010 \mathrm{~g} / \mathrm{kWh}$, respectively. Applying the appropriate GWP factors, this equates to $45.9,0.1$, and 3.0 $\mathrm{g} \mathrm{CO}_{2} / \mathrm{kWh}$, respectively. Thus, the total potential of this system to contribute to global warming is equivalent to $49 \mathrm{~g}$ of $\mathrm{CO}_{2} / \mathrm{kWh}$.

\subsubsection{Carbon Dioxide Emissions}

One of the most talked-about aspects of biomass energy is the potential reduction of atmospheric carbon dioxide per unit of energy produced. Because the carbon species released during gasification and combustion were originally removed from the atmosphere during the growing cycle, the net $\mathrm{CO}_{2}$ emissions from the system have often been assumed to be zero. However, the picture is far more complicated, involving other carbon flows: carbon species are emitted in the processes involved in biomass production and transportation, carbon may be sequestered in the soil, and not all of the carbon in the biomass is converted to $\mathrm{CO}_{2}$. Although it is certain that the net amount of $\mathrm{CO}_{2}$ emitted from a biomass-based system is less than from fossil-fueled systems, biomass power is most likely not a zero-net $\mathrm{CO}_{2}$ process. In the system being studied, $\mathrm{CO}_{2}$ was emitted from farming operations that used fossil fuels, upstream energy consumption, transportation of the biomass to the power plant, and from the power plant itself.

The carbon closure of the system can be defined to describe the net amount of $\mathrm{CO}_{2}$ released from the system in relation to the amount being recycled between the power plant and the growing trees:

$$
\text { CarbonClosure }=100-\frac{\text { Net }}{A b s} * 100=100-\frac{\text { Feed }+ \text { Trans }+P P}{A b s} * 100
$$

where: Net $=$ the net amount of $\mathrm{CO}_{2}$ released from the system after a credit is taken for the amount absorbed by the biomass in regrowth

Abs $=$ the $\mathrm{CO}_{2}$ absorbed by the biomass during regrowth

Feed $=$ the $\mathrm{CO}_{2}$ released from the feedstock subsystem, not including the credit taken for the amount absorbed by the biomass in regrowth

Trans $=$ the $\mathrm{CO}_{2}$ released from the transportation subsystem

$\mathrm{PP}=$ the $\mathrm{CO}_{2}$ released from the power plant subsystem, not including the $\mathrm{CO}_{2}$ emitted from gasification and combustion of biomass

Since fossil fuel use is the only source of $\mathrm{CO}_{2}$ that is not counterbalanced by that absorbed by the biomass, a process that does not use any fossil fuels will have a $100 \%$ carbon closure. In other words, all $\mathrm{CO}_{2}$ produced within the system would also be consumed by the system, producing a zeronet $\mathrm{CO}_{2}$ process.

The question of whether the net $\mathrm{CO}_{2}$ emissions were negative or positive was found to depend most heavily on the amount of carbon that could be sequestered in the soil. Literature data on the capacity 
of soil to retain carbon are not consistent (see section 4.1.8); moreover, such data are likely to be highly site-specific. Five studies relevant to the biomass-based system examined here report sequestration values ranging from -4.5 to $40.3 \mathrm{Mg}$ C/ha over a seven year rotation, with the upper number generally seen to be a very special case. Because the actual amount sequestered will be highly site specific, and given the wide discrepancy of values in the literature, it is impossible to say what constitutes a representative value. Therefore, a sensitivity analysis, with a base case of zero sequestration, was performed. If the soil does not sequester or lose carbon, the system achieves approximately a $95 \% \mathrm{CO}_{2}$ closure. The net emissions for this base case scenario are equal to 254 $\mathrm{kg} \mathrm{CO}_{2} / \mathrm{kW}$ of plant capacity $(46 \mathrm{~g} / \mathrm{kWh}$ ). Figure 8 shows the carbon closure for other values found in the literature. If the soil on which hybrid poplars are planted is able to sequester carbon at a rate above $1.9 \mathrm{Mg} /$ ha over the seven year rotation, the $\mathrm{CO}_{2}$ emissions from this system will be negative, resulting in a net removal of $\mathrm{CO}_{2}$ from the atmosphere. Compared to the values found in the literature, then, very little carbon sequestration is necessary to obtain a zero-net $\mathrm{CO}_{2}$ process. It should be noted that because of the release of other carbon species, such as carbon monoxide, methane, and hydrocarbons, the net carbon emissions into the atmosphere will always be higher than the net $\mathrm{CO}_{2}$ emissions. However, $\mathrm{CO}_{2}$ makes up over $99.97 \%$ (by weight) of all carbon-containing air emissions.

Figure 9 illustrates the average annual flows of $\mathrm{CO}_{2}$ from the different parts of the system. Yearly $\mathrm{CO}_{2}$ emissions are shown in Figure 10. Because the atmospheric $\mathrm{CO}_{2}$ absorbed by the biomass is allocated to the feedstock production subsystem, the net amount emitted to the atmosphere decreases in the negative years as more biomass is planted; equal $\mathrm{CO}_{2}$ absorption during each rotation is assumed. Because of plant construction, the increase in net removal of $\mathrm{CO}_{2}$ is slowed in years negative one and negative two. $\mathrm{CO}_{2}$ emissions in year one are less than the steady-state emissions in normal operating years because the power plant is operating at only $40 \%$ (50\% of the normal $80 \%$ ) capacity. $\mathrm{CO}_{2}$ emissions increase beginning in year 23 as biomass production tapers off. Finally,because of credits taken for recycling power plant equipment, $\mathrm{CO}_{2}$ emissions decrease substantially in year 30 .

\subsubsection{Air Emissions from the Power Plant: Non-Methane Hydrocarbons, NOx, and SOx}

Yearly NMHC, NOx, and SOx emissions are shown in Figures 11 through 13. Each of these three graphs have similar shapes, showing that emissions increase rapidly once the power plant is operating at full capacity. It should be noted that the total amount of these three compounds released represents only $2.3 \%$ of the mass of all air emissions.

Except for the small amount emitted in electricity generation within the feedstock production subsystem, the majority of the overall system SOx and NOx, $87 \%$ and $72 \%$, respectively, come from the power plant. The amounts emitted during normal operation are $26 \mathrm{~g} / \mathrm{GJ}$ heat input $(0.061$ $\mathrm{lb} / \mathrm{MMBtu})$ and $50 \mathrm{~g} / \mathrm{GJ}$ heat input ( $0.12 \mathrm{lb} / \mathrm{MMBtu})$, respectively. Table 24 gives the standards of performance for new electric utility steam generating units using fossil fuels, taken from the Code of Federal Regulations (40 CFR 60.43a and 60.44a). For the base case of this study, which very conservatively assumed that all of the sulfur and nitrogen contained in the biomass was converted 
Figure 8: Carbon Closure for Various Literature Values of Soil Sequestration

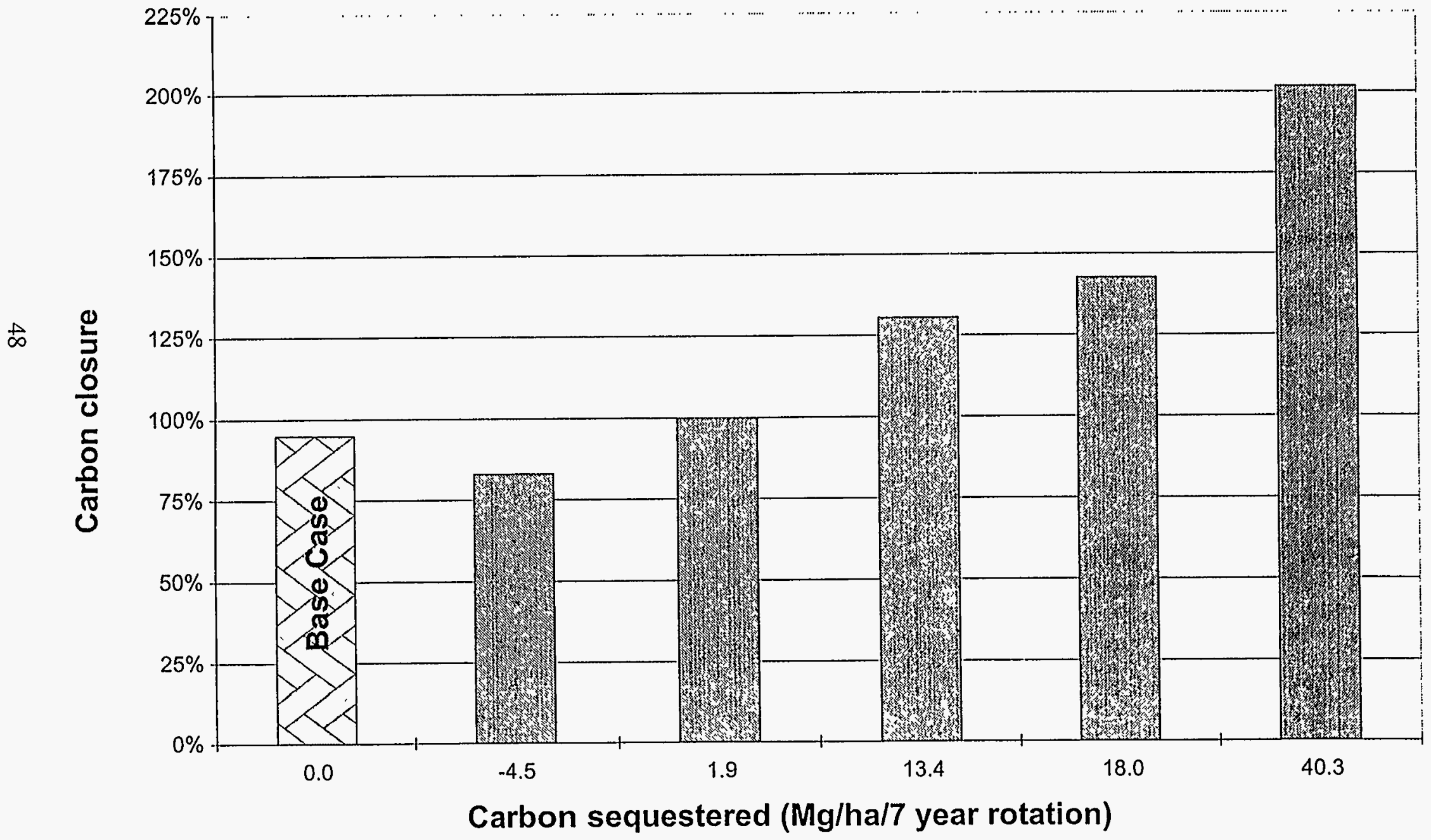




\section{Figure 9: Life Cycle Flows of $\mathrm{CO}_{2}$ within a Biomass Power System $\mathrm{g} \mathrm{CO}_{2}$ per $\mathrm{kWh}$ of Electricity (\% of net)}

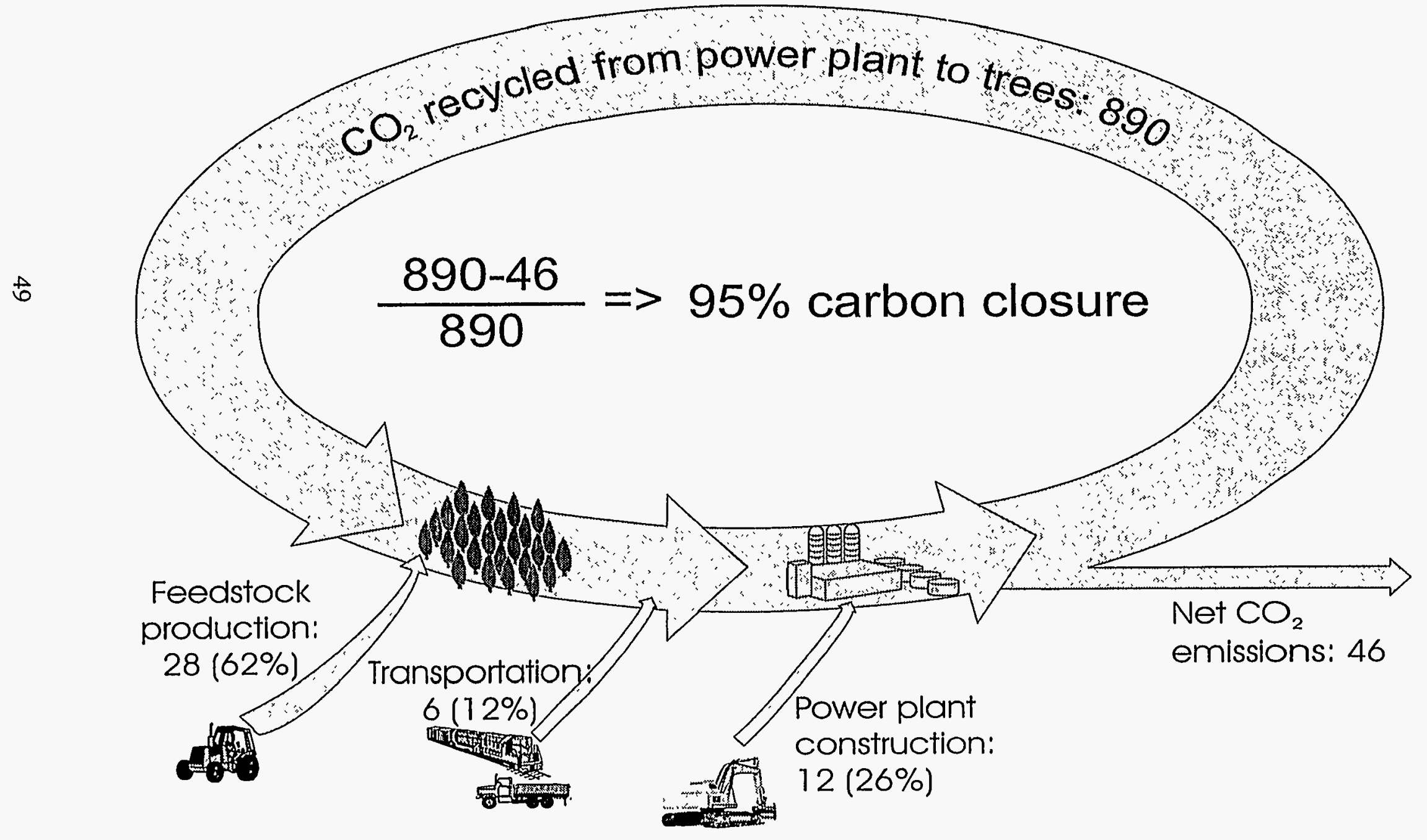




\section{Figure 10: Net Yearly $\mathrm{CO}_{2}$ Emissions Over the Life of the System}

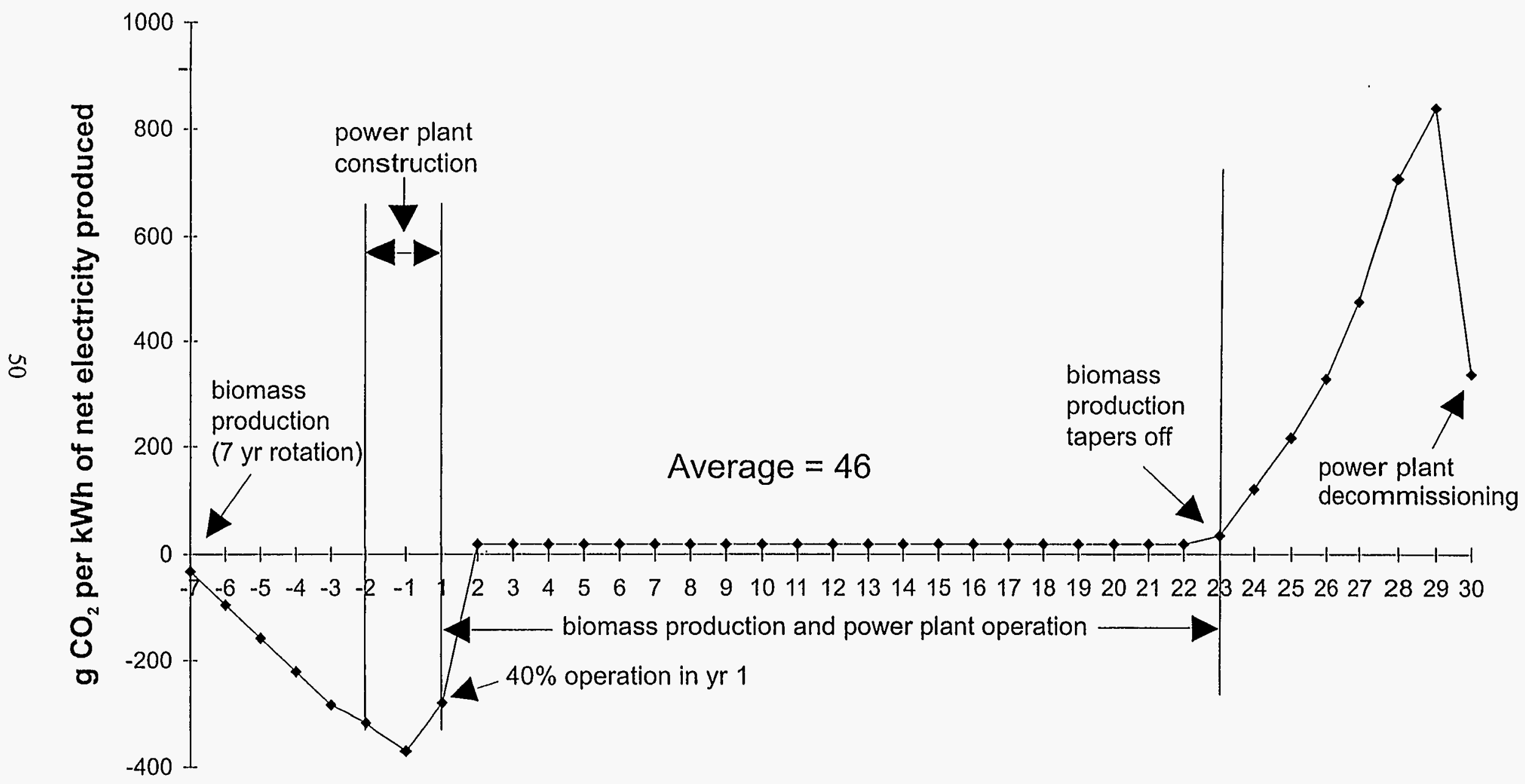

Year of System Operation 


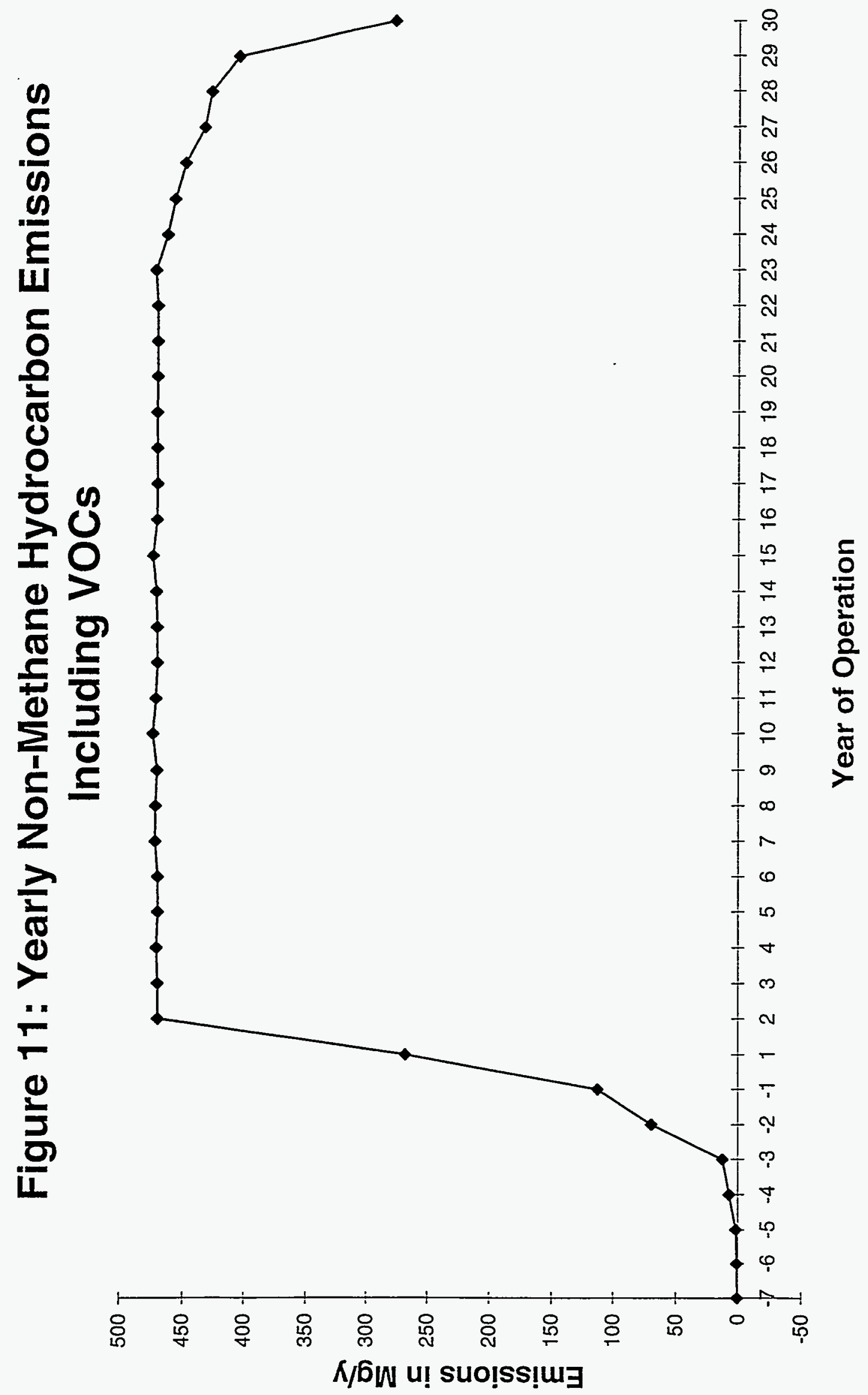




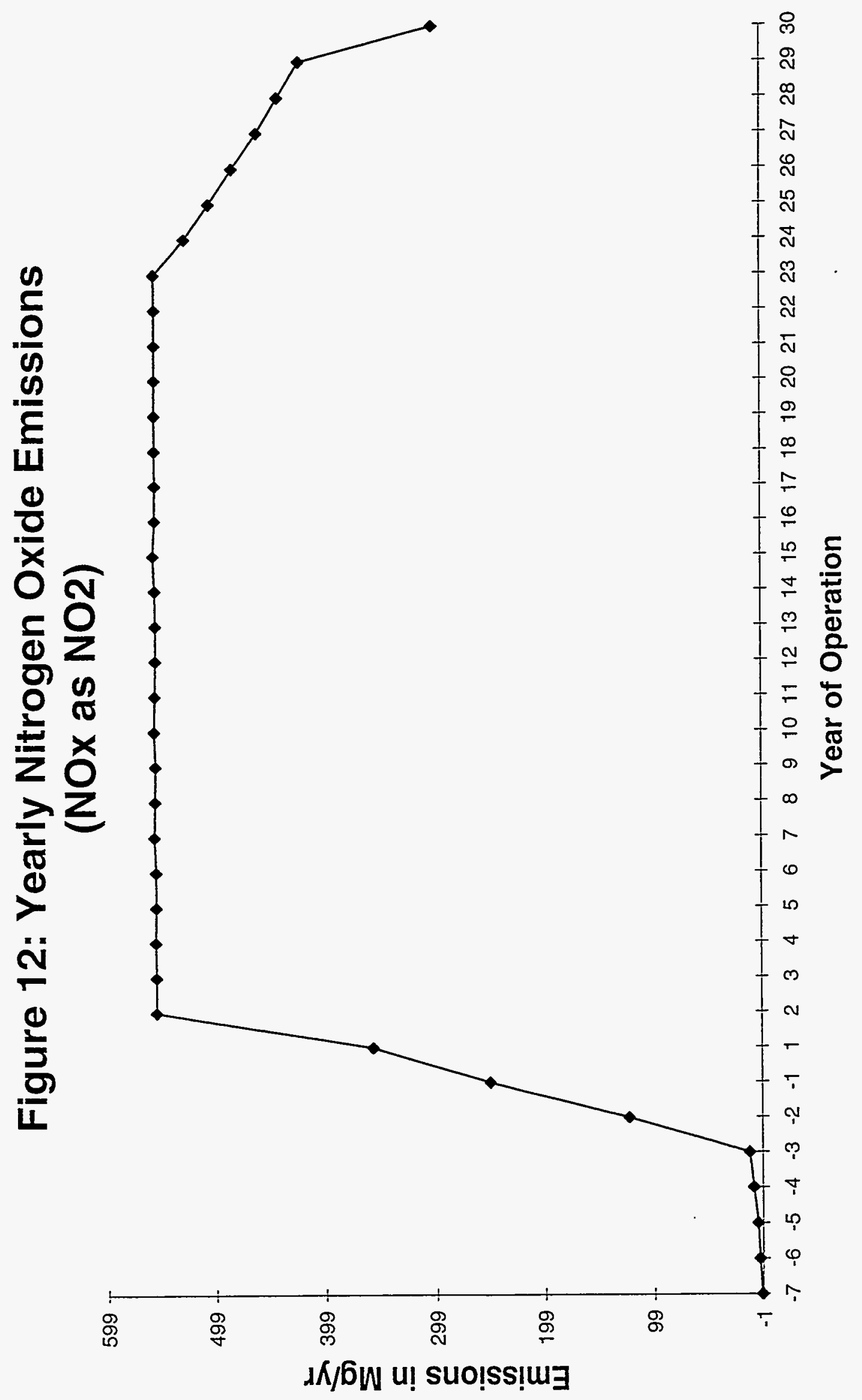


Figure 13: Yearly Sulfur Oxide Emissions (SOx as SO2)

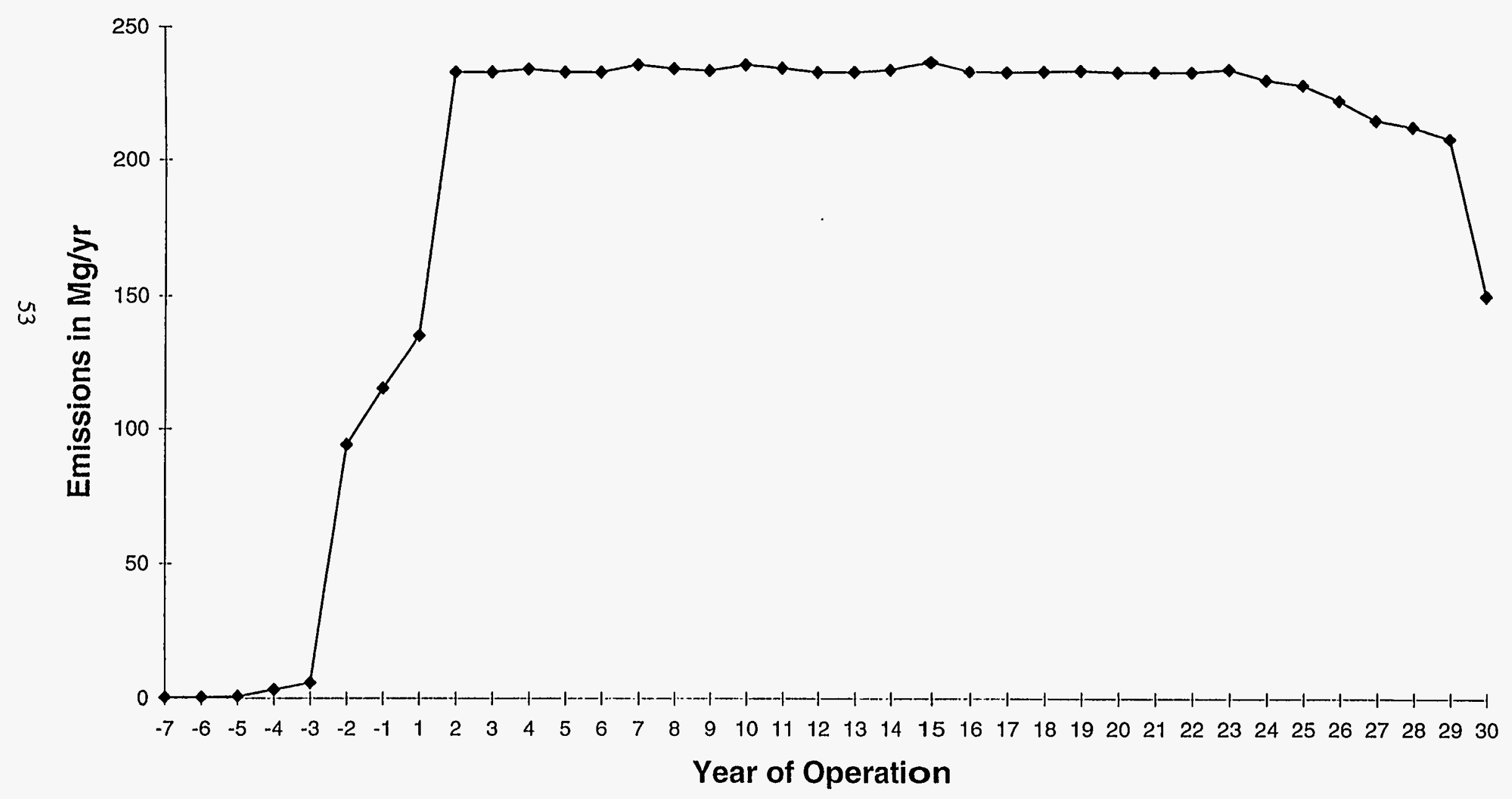


to SOx and NOx, the SOx emissions are one-tenth of the New Source Performance Standard (NSPS) requirement and the NOx emissions are one-fifth of the NSPS requirement.

Table 24: New Source Performance Standards for Fossil-Fueled Power Plants

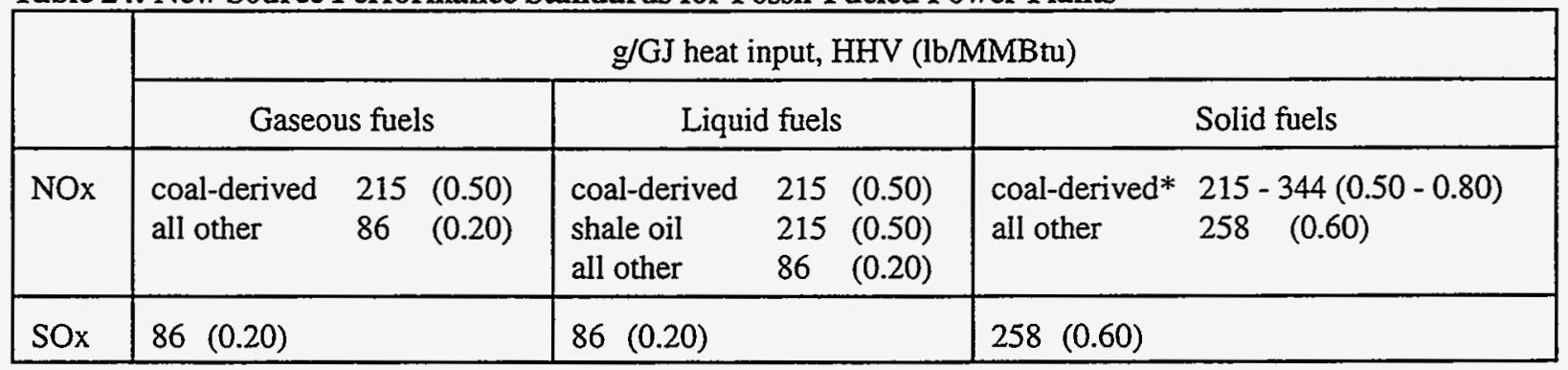

* Allowable emissions depend on the type of coal.

\subsubsection{Particulate Emissions}

Particulate matter is a collective term used to describe very small solid and/or liquid particles. Particulates are produced by diesel-fueled farm equipment and during power plant construction and operation. The average amount emitted over the life of the system is $40 \mathrm{~g} / \mathrm{MWh}$ of energy produced/year (232 kg/year/MW of plant capacity), which represents only $0.06 \%$ of the total air emissions (by weight) and only $0.18 \%$ excluding $\mathrm{CO}_{2}$ (Table 19). Figure 14 shows, however, that during the two years of plant construction, 249 and $271 \mathrm{~g} / \mathrm{MWh}(1,380$ and 1,500 kg/year/MW of plant capacity) of particulates are emitted. Impacts associated with particulate emissions will be more significant in these years than in any other during the life of the system.

According to the Code of Federal Regulations (40 CFR 60.42a) the NSPS for particulates from a new power plant fueled with any combination of gaseous, liquid, or solid feedstock is $13 \mathrm{~g} / \mathrm{GJ}$ of heat input $(0.03 \mathrm{lb} / \mathrm{MMBtu})$. The amount of particulates emitted from the power plant in this study during normal operation is $0.47 \mathrm{~g} / \mathrm{GJ}(0.0011 \mathrm{lb} / \mathrm{MMBtu})$. Therefore, the power plant is well below the amount of allowable emissions. Note that these emissions are from the power plant only and do not include any of the upstream processes involved in feedstock production. Likewise, upstream process emissions are not included in the NSPS.

Wood dust is created where mechanical means are used to cut, shape, or otherwise change the size of wood products. Because of a lack of data, the dust emitted in chipping and moving the biomass was not included in this assessment. Storage of biomass also creates environments for the proliferation of microorganisms including mold, fungi, and associated spores that may induce allergic reactions. Perlack et al (1992) list two potential problem microorganisms associated with moulding wood (originally reported in Egeneus and Wallin (1985)). Jirjis (1997) reports that the microorganisms most seen with stored wood chips are moulds and actinomycetes. Associated respiratory diseases of varying symptoms, severity, and long-term effects are discussed. It is likely that by storing the biomass in whole-tree form until shortly before it is needed by the power plant, the health effects of rotting wood can be minimized. 


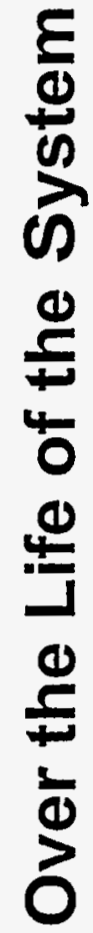

$\frac{0}{0}$

$\frac{\mathscr{n}}{\mathrm{E}}$

$\Phi$

$\frac{\pi}{\pi}$

J

0

$\pi$

n

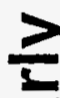

$\pi$

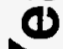

$\ddot{8}$

0

은

으

는

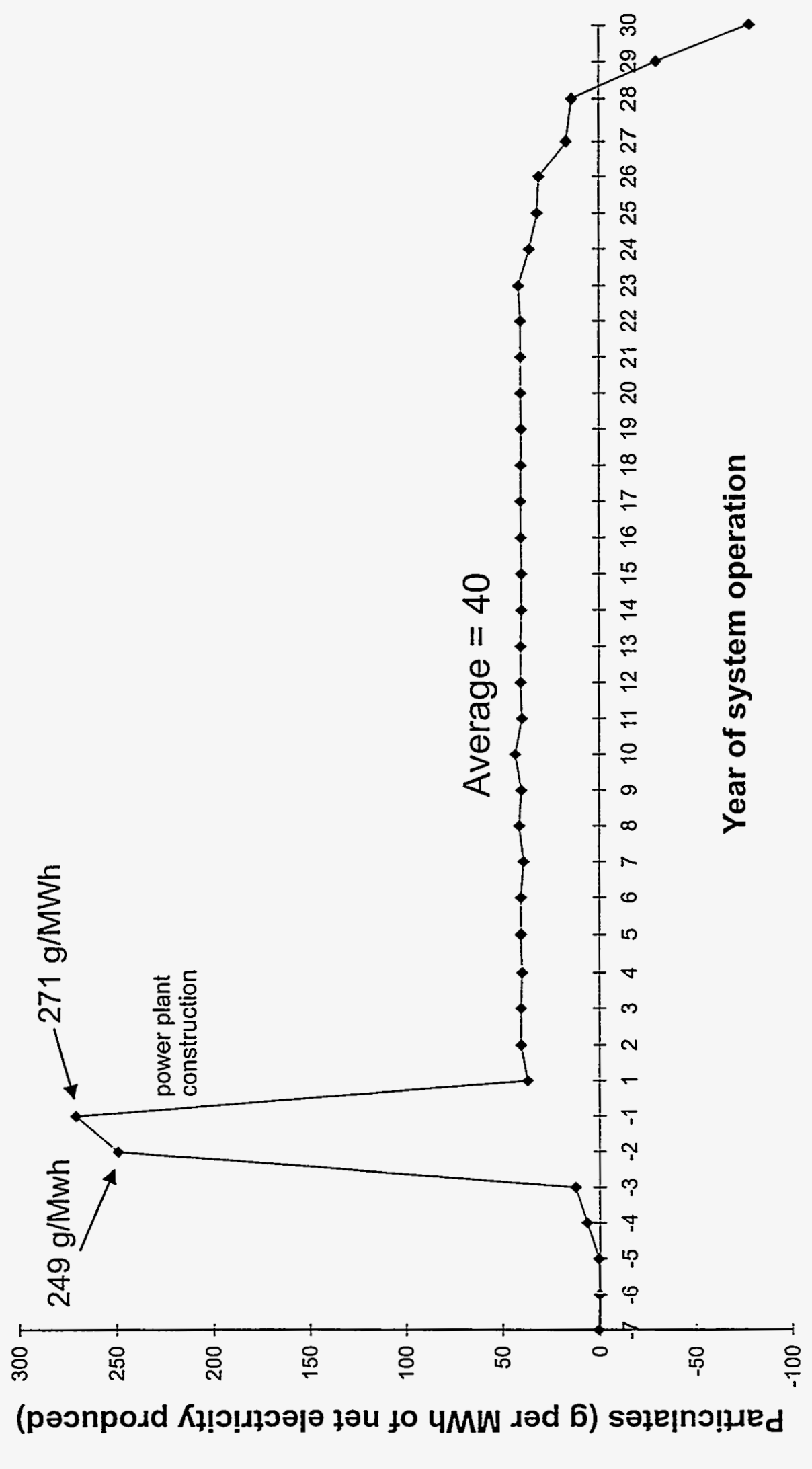




\subsubsection{Carbon Monoxide Emissions}

Carbon monoxide emissions represent only $0.4 \%$ of the mass of the total air emissions excluding $\mathrm{CO}_{2}$. The annual releases are shown in Figure 15. The main source of this stressor is fossil fuel use in the feedstock production subsystem.

\subsection{Water Emissions}

Most emissions to water from the system occurred in the feedstock production subsystem, although the power plant produces a significant amount of water that is treated in-house. About 93\%, by weight, of the water pollutants produced in the feedstock subsystem come from diesel oil production; $6 \%$ come from ammonium nitrate production. In general, though, the total amount of water pollutants was found to be small compared to other emissions. Table 20 shows that dissolved matter and ammonia $\left(\mathrm{NH}_{4}+\right)$ make up $83 \%$ and $12 \%$ of all water emissions. It should be emphasized that because of data unavailability, emissions of fertilizer and herbicide into water systems surrounding the plantation were not included in the life cycle assessment and therefore are not included in this table. However, if riparian filter strips are used, a significant portion of the fertilizers and herbicides that dissolve in surface waters can be removed before passing beyond the boundaries of the plantation (see Sears, 1996, for a detailed discussion on the ability of such strips to reduce effects on surface waters).

\subsection{Energy and Resource Consumption}

Yearly energy consumption for the system is shown in Figure 16, while average energy flows are shown in Figure 17. Use is highest in year negative one because of plant construction, and is negative in year 30 because of credits taken for recycling during decommissioning. A breakdown of energy consumption by the three subsystems is shown in Table 21 . Not including power plant parasitic losses, feedstock production accounts for $77 \%$ of the system energy consumption. In order to study the energy budget of this system, three types of efficiencies can be defined. First, the traditional definition of energy efficiency gives the fraction of energy in the feedstock to the power plant that is delivered to the grid. The system studied was found to have a power plant efficiency of $37.2 \%$ (higher heating value basis). The life cycle efficiency, which includes the energy consumed by all upstream processes, is then defined as follows:

$$
\text { LifeCycleEfficiency }=\frac{E g-E u}{E b}
$$

where: $\quad E g=$ electric energy delivered to grid

$\mathrm{Eu}=$ energy consumed by upstream processes

$\mathrm{Eb}=$ energy contained in the biomass fed to the power plant. 


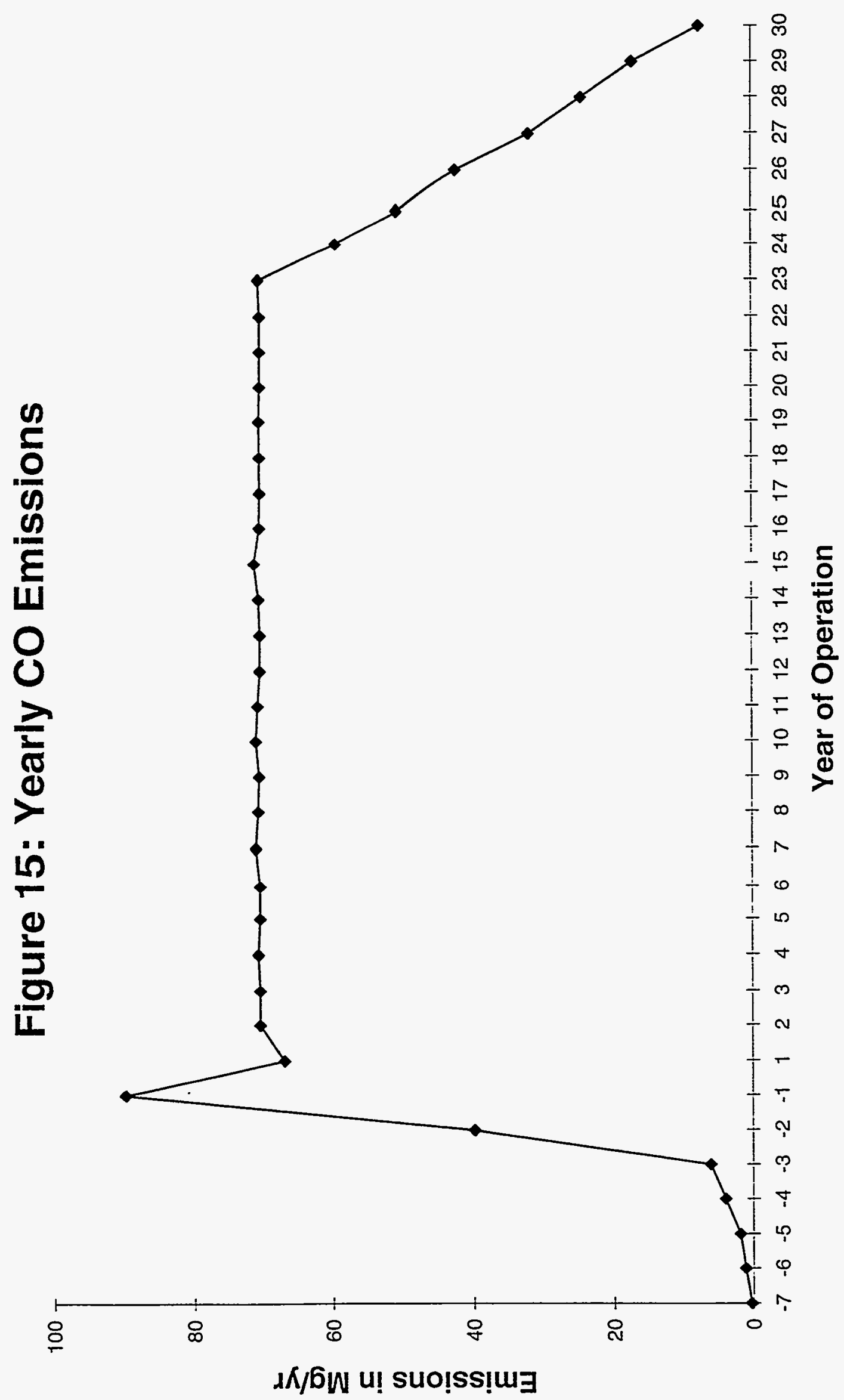


Figure 16: Yearly Total Energy Consumption Over the Life of the System (Note: Electrity produced and consumed by the power plant not included)

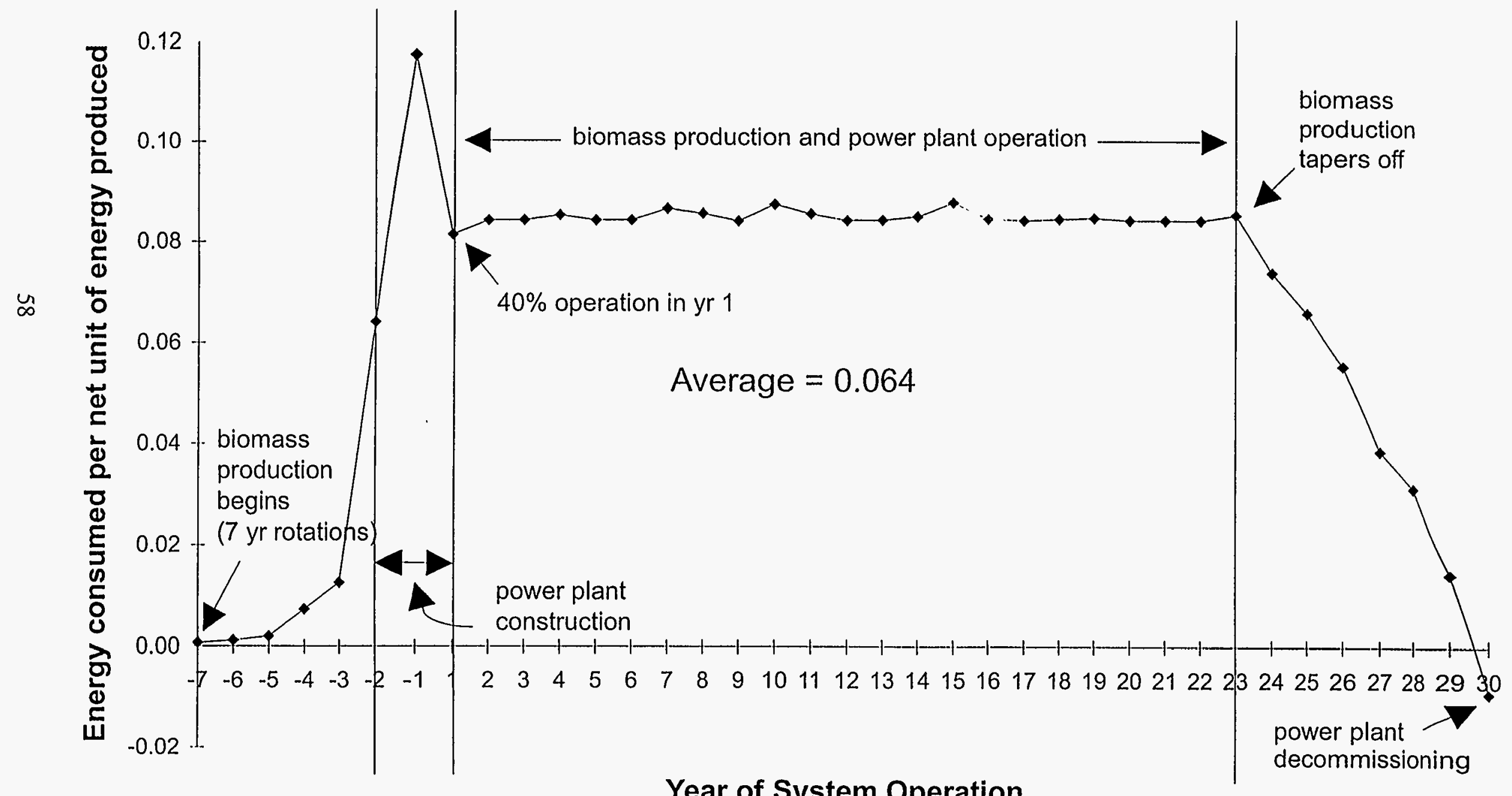




\section{Figure 17: Life Cycle Energy Flows within a Biomass Power System (per one unit of fossil fuel energy consumed)}

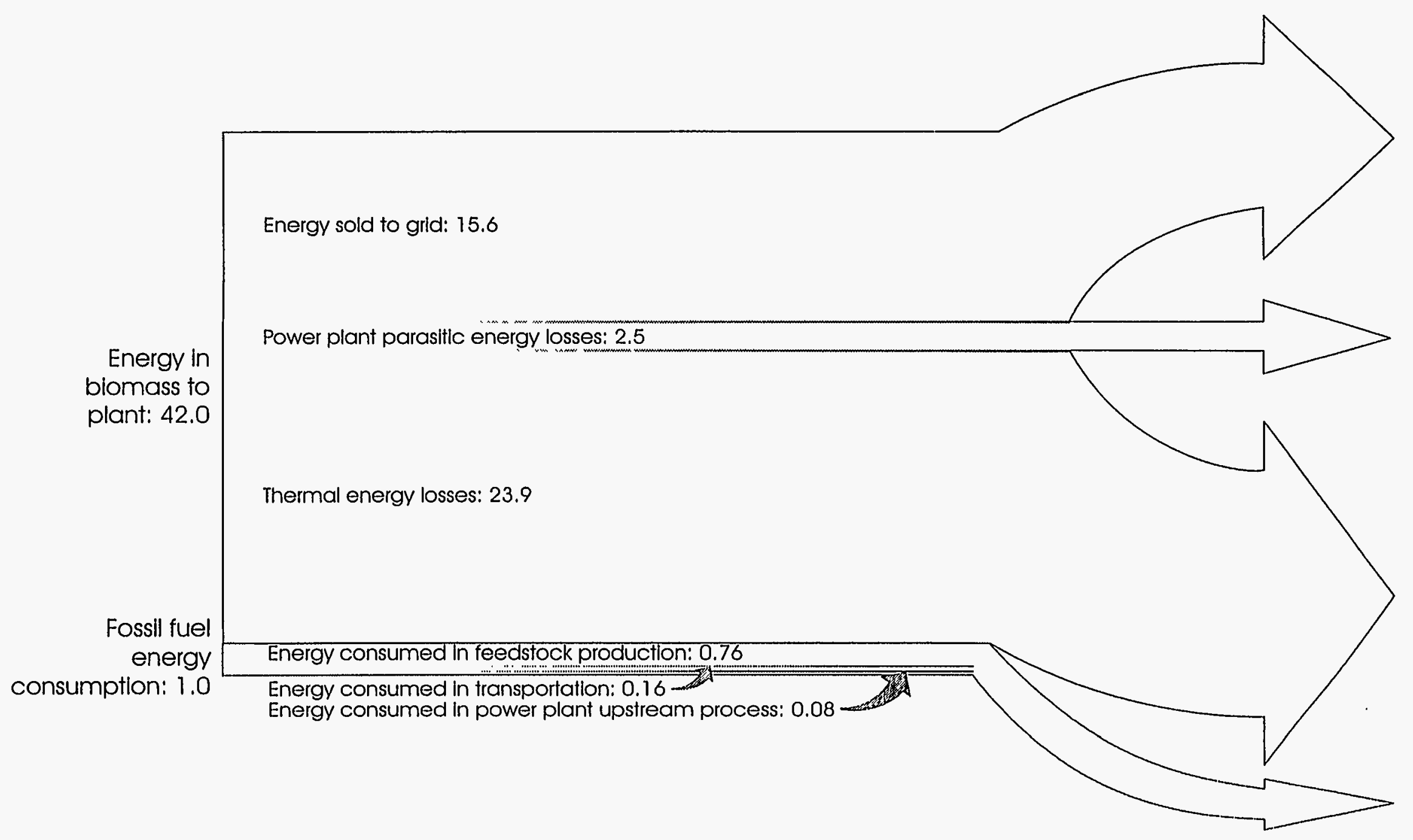

Note: Drawing is to scale therefore the breakdown of fossil fuel energy is difficult to depict with individual arrows. 
The life cycle efficiency for this operation is equal to $34.9 \%$. To understand how much energy is produced for each unit of fossil fuel energy consumed, a net energy ratio is calculated:

$$
\text { NetEnergyRatio }=\frac{E g}{E f f}
$$

where: $\quad E g=$ electric energy delivered to grid

Eff $=$ fossil fuel energy consumed within the system.

This ratio does not take into account any renewable resource energy, since by definition, renewables are not considered to be consumed within the boundaries of the system. For this operation, the net energy ratio was found to be equal to 15.6. Thus, significantly more energy is produced than consumed.

In the context of this life cycle assessment, the term resource refers to any material consumed within the system boundary. Energy is not included in this term because it is accounted for by including the material that was used to produce it. From a life cycle viewpoint, renewable and sustainable are the same, and will be defined to be a substance replenished at a rate equal to or greater than its rate of consumption. Therefore, the biomass and its associated energy are not considered to be consumed by the system since they are also generated by the system. It is important to note that a substance is either termed renewable or non-renewable, and that its classification within these two groups is not dependent on the size of the remaining reserve. In assessing resource depletion in the inventory and impact portions of this study, the effects on society as a result of dwindling stock reserves were not assessed. Similarly, no estimations of the total reserve available were made.

Table 22 shows that water accounts for the vast majority of all resources consumed by the system. Excluding water use, oil, iron (ore and scrap), and coal account for $65 \%, 18 \%$, and $12 \%$, respectively, of the total resources (by weight). As expected, feedstock production requires the majority of the fossil fuels used in the system. The percentage of the total consumption of coal, natural gas, and oil used in the feedstock subsystem equals $67 \%, 95 \%$, and $79 \%$, respectively. Because of equipment manufacturing and construction, the power plant was found to require more electricity, and thus more coal and natural gas, than biomass transportation. However, the amount of oil consumed in transportation is higher than in the power plant subsystem. The annual requirements of oil, coal, and natural gas are shown in Figures 18 through 20. Figure 21 is also shown because iron, from ore and scrap, was consumed in significant quantities compared to other resources. 


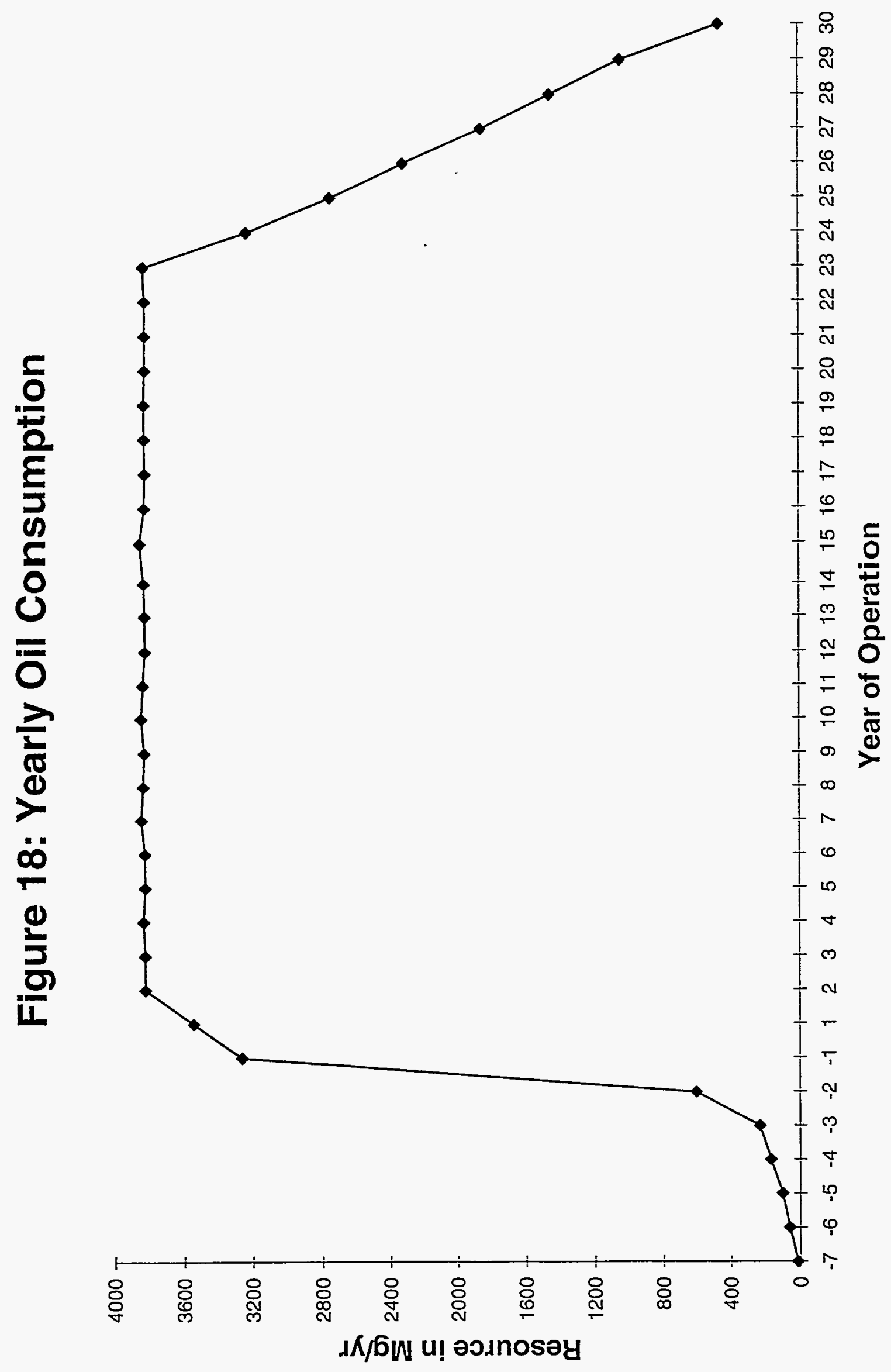




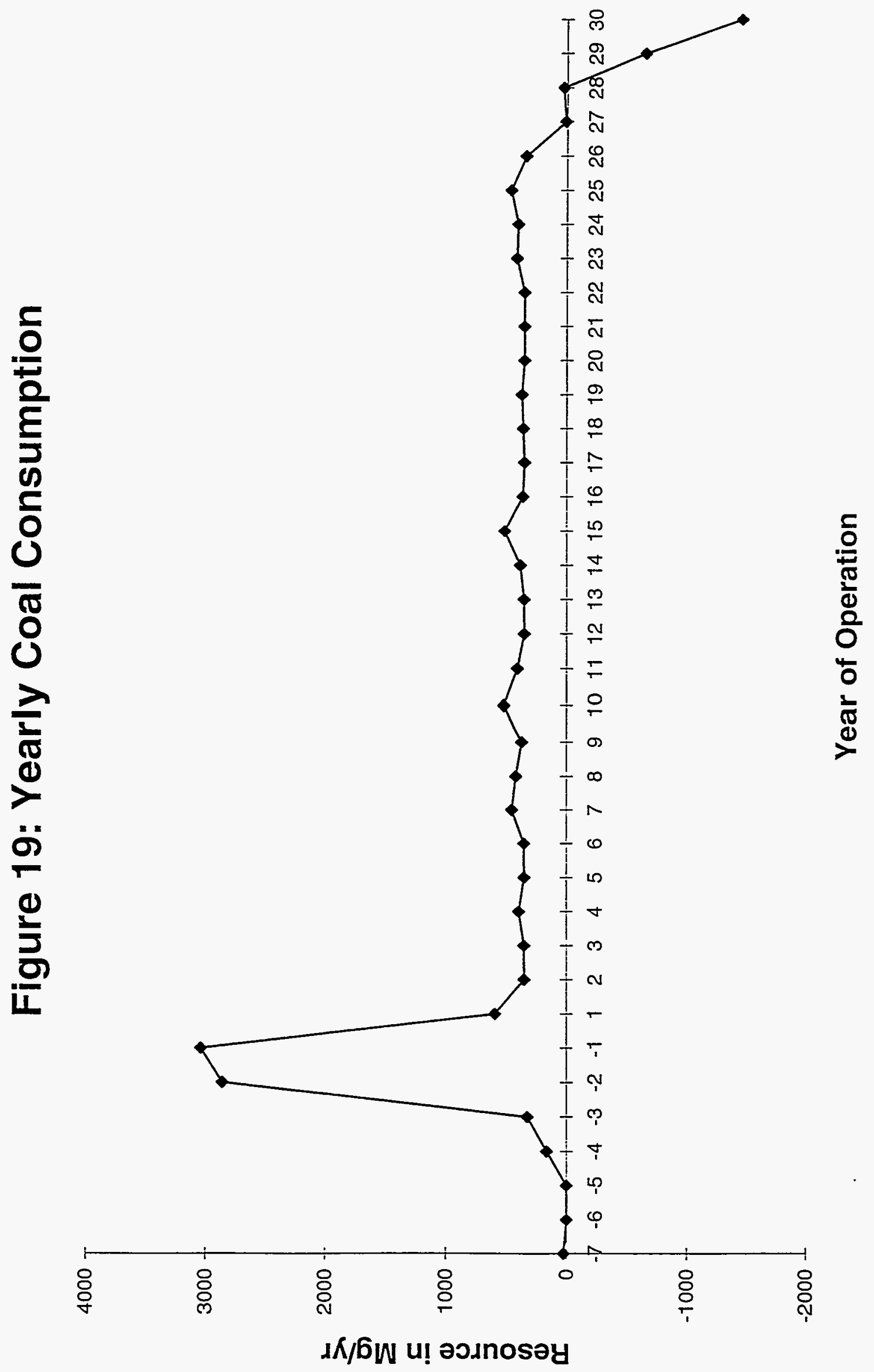




\section{Figure 20: Yearly Natural Gas Consumption}

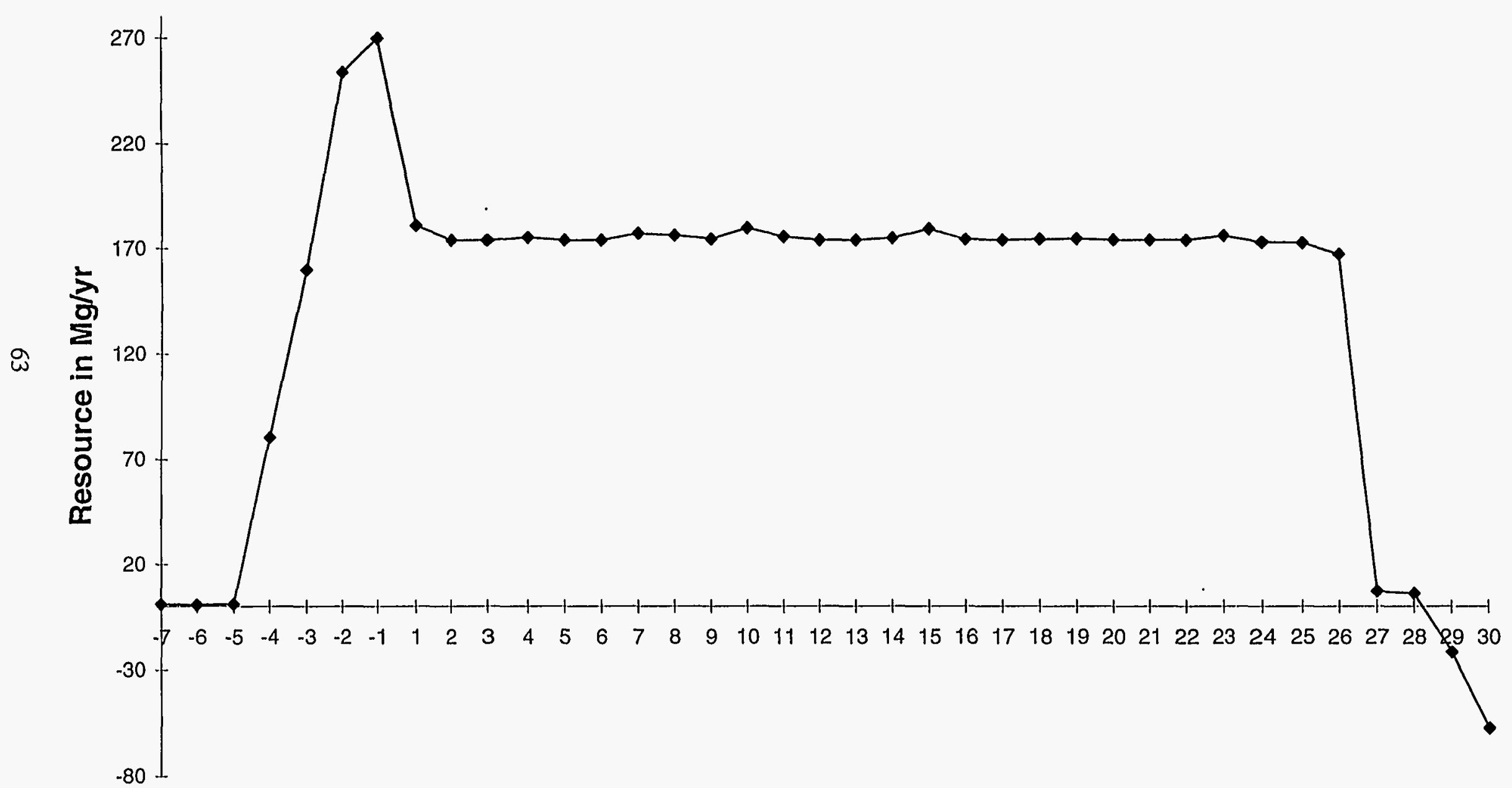

\section{Year of Operation}


Figure 21: Yearly Iron Consumption (ore + scrap)

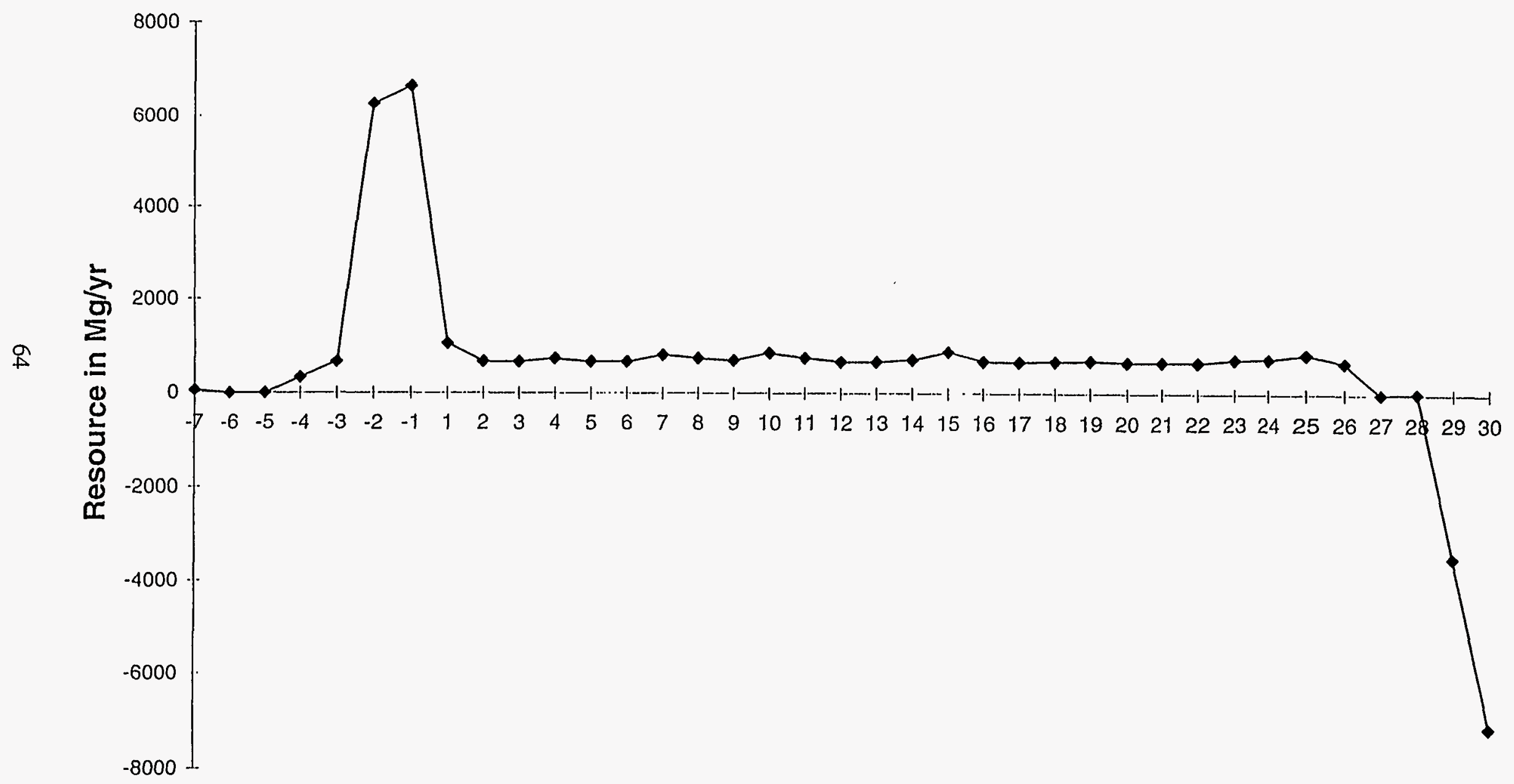

Year of Operation 


\subsection{Solid Waste}

Figure 22 shows the annual production of solid waste from the system. Non-hazardous solid waste was found to be the only solid waste produced in any significant quantity. TEAM defines several types of waste, and reports that unspecified, and municipal and industrial, can be combined to represent non-hazardous (See Table 23). The yearly variation in solid waste generation is the result of intermittent decommissioning and production of trucks and farm equipment.

\subsection{Results Specific to the Three Major Subsystems}

\subsection{Base Case Feedstock Production Results}

As stated earlier, feedstock production accounts for $77 \%$ of the non power-plant system energy consumption. Figure 23 shows that fossil fuel use in farming operations consumes the majority of this energy (83\% of feedstock energy, $64 \%$ of total system energy). The second largest consumer of energy is the transportation of fertilizers and herbicides to the field. This accounts for $9 \%$ of feedstock energy and $7 \%$ of total system energy consumption. Because of the natural gas required to manufacture ammonium nitrate and urea, fertilizer production accounts for $6 \%$ of the energy used in the feedstock production subsystem, and $5 \%$ of the total system energy.

Figure 24 shows the source of $\mathrm{CO}_{2}$ emissions in feedstock production, excluding that absorbed by the biomass. As expected, diesel fuel combustion in farming operations accounts for most of the $\mathrm{CO}_{2}$ emitted (79\% feedstock, $49 \%$ system). Diesel fuel production, which includes extraction and processing, emits $7 \%$ ( $4 \%$ system), while farm chemical transportation emits $9 \%$ ( $5 \%$ system). $\mathrm{CO}_{2}$ is emitted from natural gas reforming operations in nitrogen fertilizer production.

Particulate emissions in feedstock production are shown in Figure 25. Although the combustion of fossil fuels in tractors and chippers emits the majority of the particulates to the air (56\% feedstock, $31 \%$ total), those from transportation of chemicals to the farm were also found to be significant ( $31 \%$ feedstock, $18 \%$ system). Additionally, because of prilling operations and coupled energy use, ammonium nitrate manufacturing produces $7 \%$ of the total particulates released in feedstock production, and $4 \%$ from the entire integrated system.

Non-methane hydrocarbon emissions (including VOCs) for the feedstock production subsystem are shown in Figure 26. The majority (45\% of feedstock and 5\% of system NMHC emissions) are released during diesel oil combustion, but it's interesting to note that one-third are emitted in extracting crude oil and producing diesel fuel. Farm chemicals transport also emits a significant fraction of feedstock NMHC. 
Figure 22: Yearly Total Solid Waste

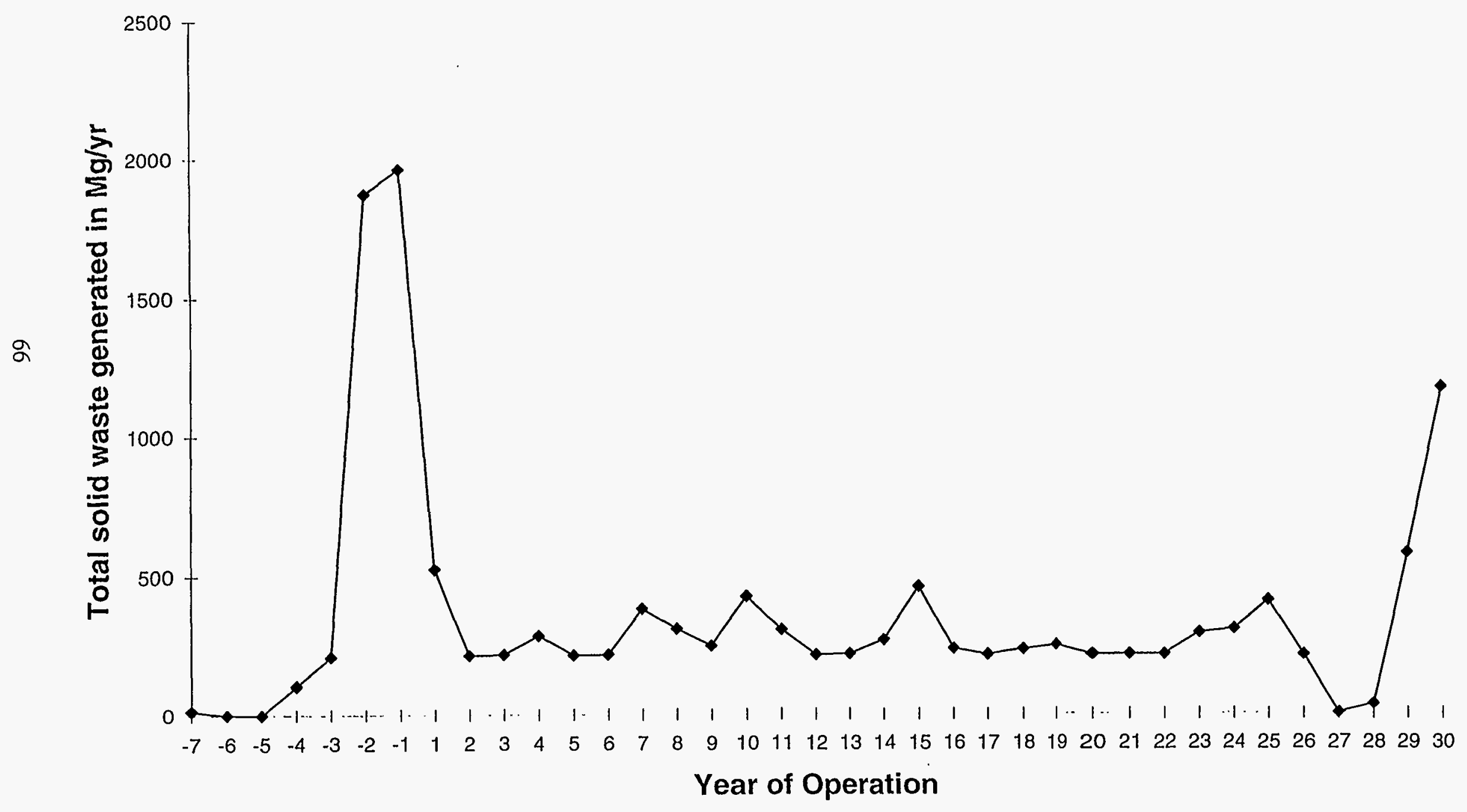




\section{Figure 23: A Breakdown of Energy Consumption in Feedstock Production}

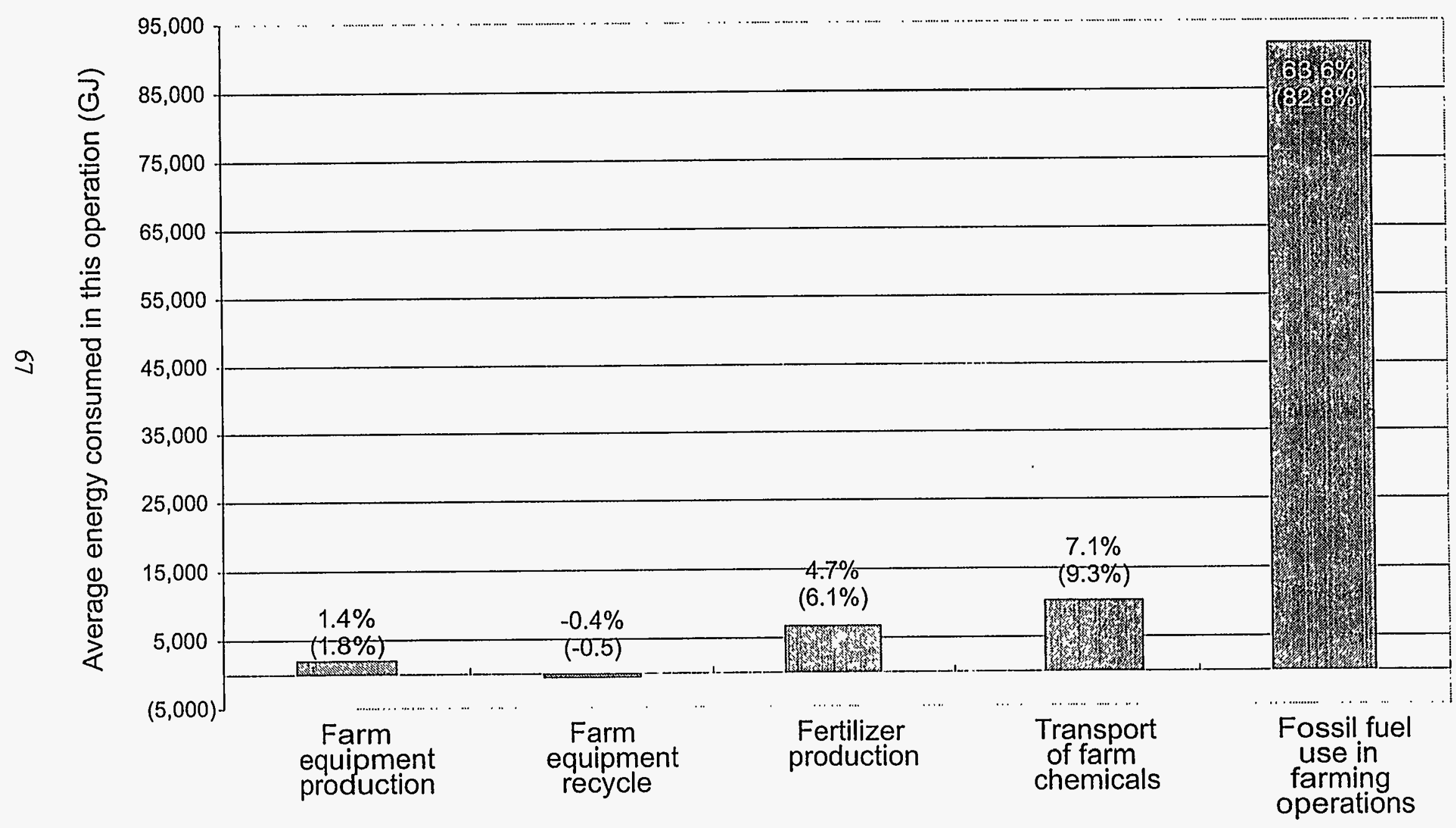

$\%$ of total system energy consumption

(\% of feedstock energy consumption) 


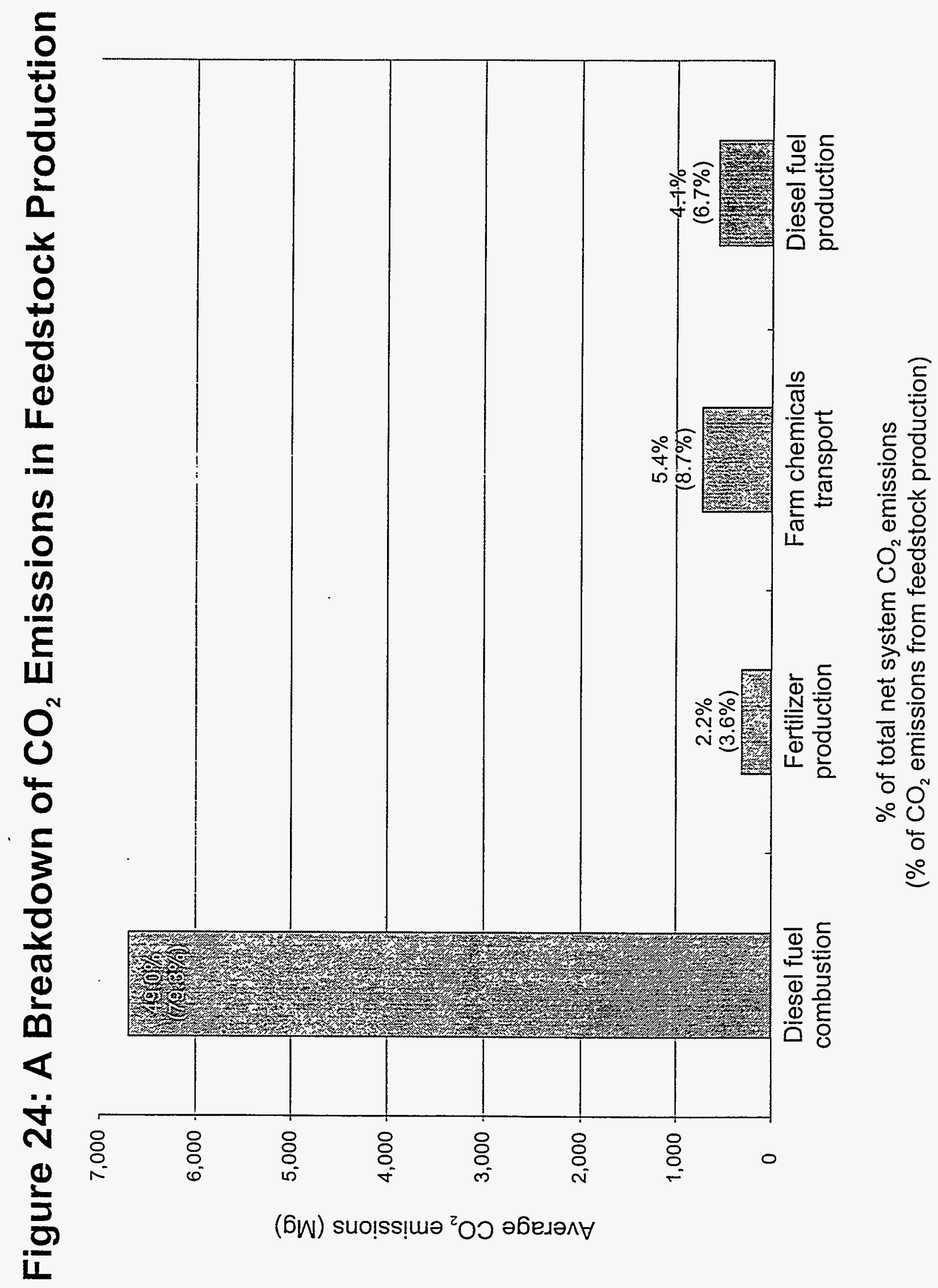




\section{Figure 25: A Breakdown of Particulate Emissions in Feedstock Production}

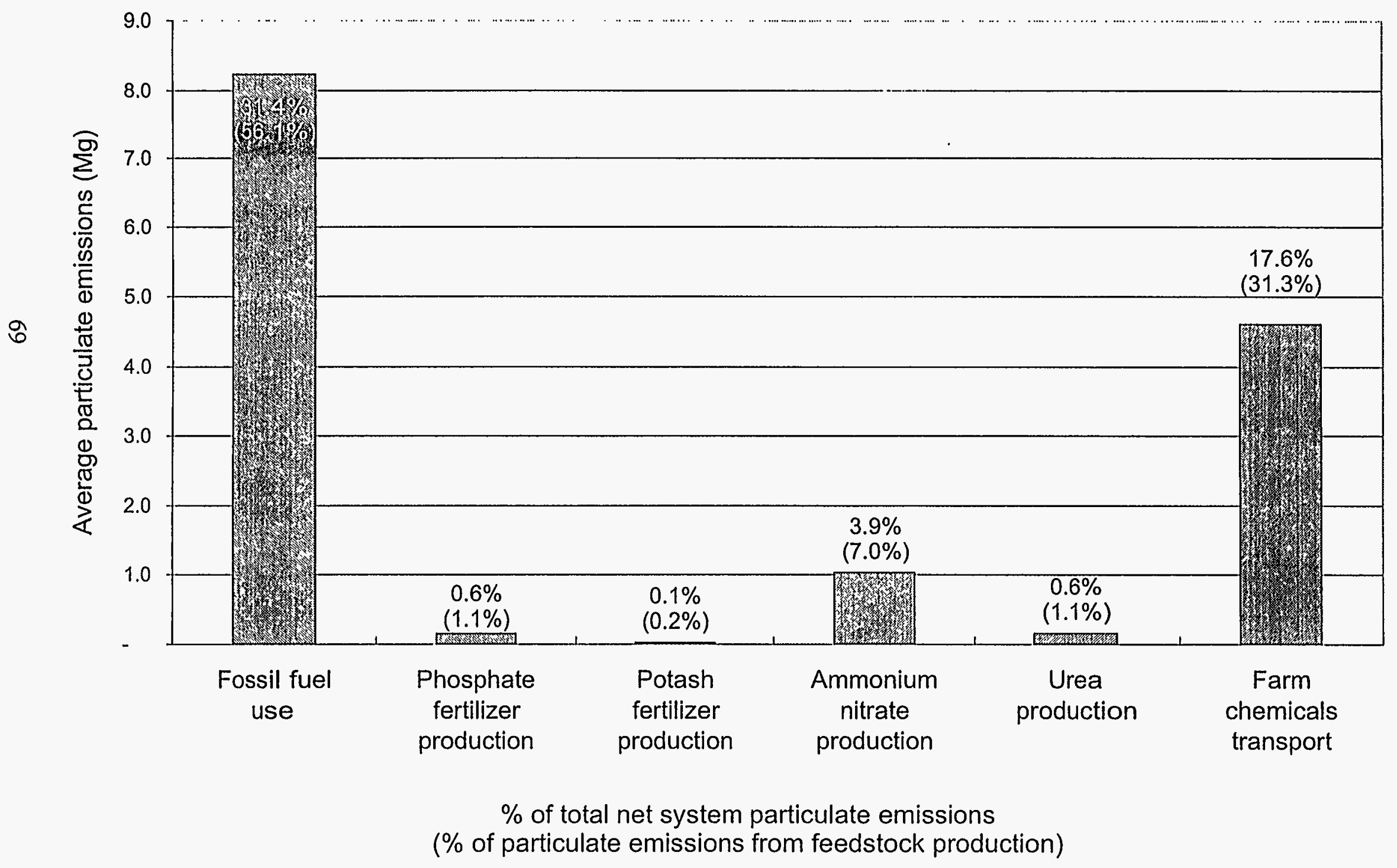




\section{Figure 26: A Breakdown of Non-Methane Hydrocarbon Emissions in Feedstock Production}

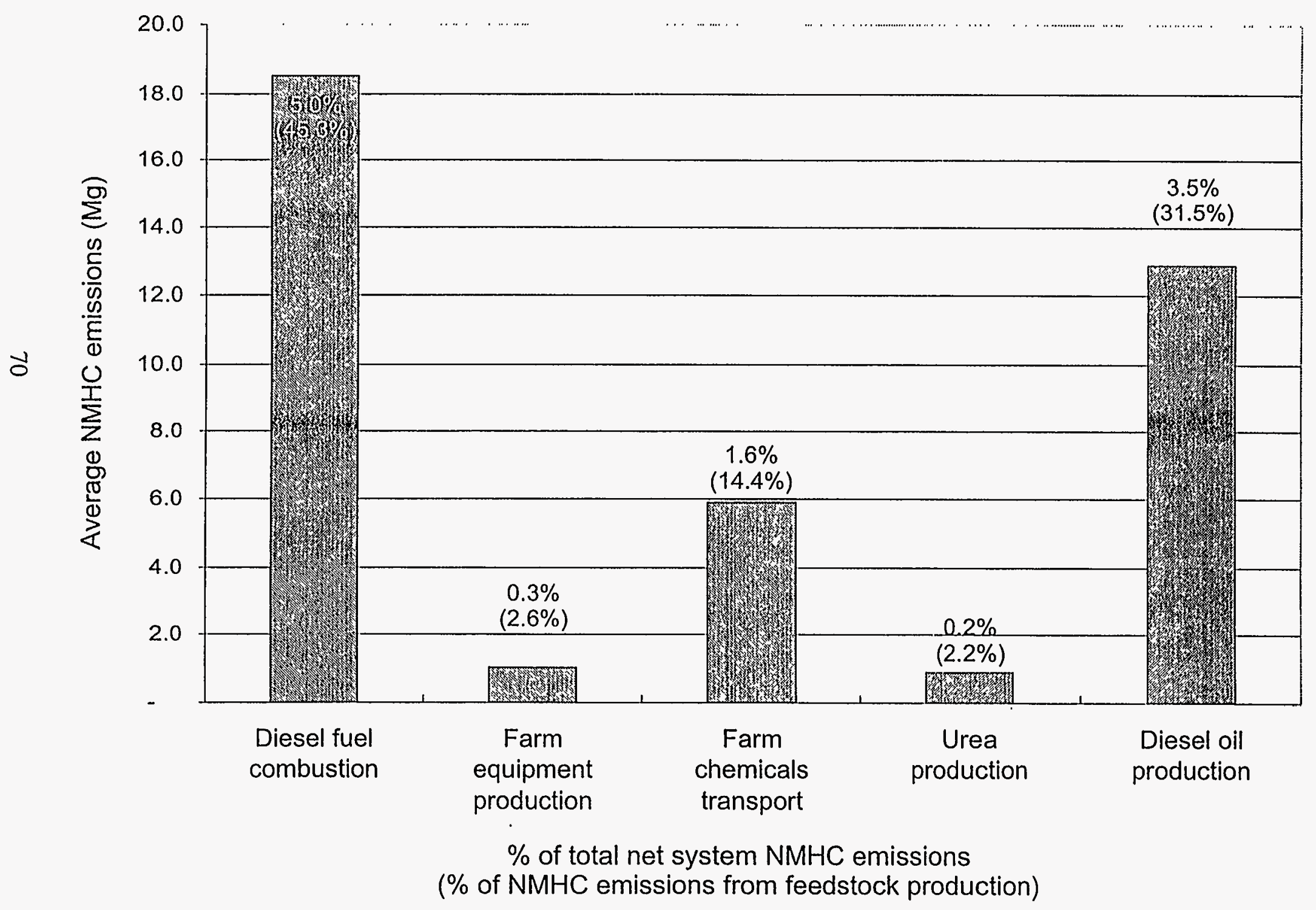


Soil erosion rates will depend on specific site conditions and previous land uses. However, established and extensive root systems in short rotation woody crops minimize soil erosion and more efficiently take up nutrients than annual row crops which must establish new root systems each year (Thornton et al, 1997). Ranney and Mann (1994) estimate that soil erosion from short-rotation woody crops on a $5 \%$ slope will be $2,000 \mathrm{~kg} / \mathrm{ha} /$ year, averaged over the life of the plantation. However, zero ground cover was assumed in deriving this number, and thus it may represent the worst case scenario. In order to obtain more reliable data, actual sediment losses are being measured in current field trials. Table 25 shows the sediment loss in ORNL's most recent field trials for the first two years of short rotation woody crops (Tolbert, 1997). Erosion rates at the plots without ground cover are expected to start to decrease to levels seen at plantations with cover as the trees mature. Note that the numbers presented in this table are for periods of three months. The highest erosion rates were typically associated with rainfall events and occurred during seasons when ground cover and crown cover were minimal. Therefore, it would not be correct to multiply the numbers shown in this table by four to obtain annual erosion values.

Table 25: Sediment Loss Measured in First Two Years of Growth in Recent Field Trials*

\begin{tabular}{|l|l|c|c|c|}
\hline \multirow{2}{*}{} & \multirow{2}{*}{ Tree } & \multicolumn{3}{|c|}{ Sediment Loss (kg/ha/three months) } \\
\cline { 3 - 5 } & & Low value & High value & Average \\
\hline Alabama A\&M, with cover & Sweetgum & 20 & 250 & 111 \\
\hline Alabama A\&M, without cover & Sweetgum & 280 & 1300 & 749 \\
\hline Ames Plantation, TN & Sycamore & 10 & 105 & 30 \\
\hline Stoneville, MS & Cottonwood & 0 & 250 & 91 \\
\hline
\end{tabular}

Data from these same field trials have show that nitrogen and phosphorus movement into the surrounding environment is negligible compared with no-till corn (Tolbert et al, 1997). Further, the use of riparian filter strips can significantly mitigate the run-off of chemicals (Sears, 1996). Another possibility is to plant short rotation woody crops along the boundaries of current food crops. This would reduce the negative effects of chemicals leaching from row crops and satisfy some or all of the nutrient needs of energy crops at the same time.

$\mathrm{N}_{2} \mathrm{O}$ represents only $0.01 \%$ by mass of the total air emissions shown in Table 19 , and as discussed in section 5.1, has one-fifteenth of the global warming potential of $\mathrm{CO}_{2}$ from this system. Approximately $96 \%$ of system $\mathrm{N}_{2} \mathrm{O}$ emissions come from feedstock production, with the majority of those (58\%) coming from diesel oil combustion during farming operations. Nitrification of fertilizers at the plantation is responsible for $40 \%$. The high literature value for this source of $\mathrm{N}_{2} \mathrm{O}$ was assumed to arrive at this number, and since emissions were not found to be substantial, further sensitivity runs with lower values were felt to be unnecessary. 


\subsection{Base Case Biomass Transportation Results}

Of the three subsystems considered in this life cycle assessment (feedstock production, transportation, and electricity production), transportation requires the fewest resources and least amount of energy. The air and water emissions are also lowest from this subsystem. The resources, energy requirements, and emissions range from 2 - 19\% of the total over the life of the plant (see Tables 19-23), with the majority around 4\%. Therefore, any changes in the transportation subsystem will have some effect on the analysis but will not significantly change the overall impact of the system on the environment.

When comparing truck and train emissions, it is evident that transporting biomass by rail is less polluting. For the base case, the split was $70 \%$ by trucks and $30 \%$ by rail cars. However, as shown in Table 26, the split of stressors from these two modes of transportation is greater than 70/30. This table shows that most of the transportation emissions (by weight) are split with $26 \%$ from rail car use and $74 \%$ from truck use. However, transportation by rail car emits slightly more SOx to the atmosphere, but fewer $\mathrm{CH}_{4}, \mathrm{NOx}, \mathrm{CO}$, hydrocarbons and particulates. Less $\mathrm{N}_{2} \mathrm{O}$ is released from this system because it incorporates some rail transport than would be if the sole mode of transportation was by truck.

\subsection{Base Case Power Plant Construction \& Decommissioning Results}

The main emissions from cement manufacturing are particulate matter, $\mathrm{NOx}, \mathrm{SOx}, \mathrm{CO}_{2}$, and $\mathrm{CO}$. Small amounts of volatile organic compounds, ammonia, chlorine, and hydrogen chloride may also be emitted. Sources of particulates include quarrying and crushing, raw material storage, grinding and blending, clinker production, and packaging and loading. Fuel combustion required for these processing steps produces nitrogen oxides, sulfur dioxide, carbon monoxide, and carbon dioxide. Sulfur dioxide is also generated from the sulfur compounds in the raw materials. Substantial quantities of $\mathrm{CO}_{2}$ are produced through calcining of limestone through decomposition of $\mathrm{CaCO}_{3}$ to $\mathrm{CaO}$ and $\mathrm{CO}_{2}$. As can be seen in Figure 27, 83\% of the $\mathrm{CO}_{2}$ emissions emitted during construction are attributed to the production of cement. The second largest percentage of emissions is from steel production from ore. This result is expected since these two materials are used in the greatest quantity in power plant construction.

Table 27 is a breakdown of the emissions for each of the materials used in plant construction. They are shown as a percent of the total construction emissions. In general, the largest percentage of the overall emissions come from the processes involved in manufacturing cement followed by those required to produce steel. Aluminum production from ore is a very energy-intensive process, requiring more energy (2.7 times) than iron or steel production. This difference cannot be seen in Table 27 since the amount of aluminum used during plant construction is overshadowed by the steel requirement. Figures 28 and 29 show the breakdown of energy requirements in construction. 


\section{Resources}

(r) Bauxite (AL2O3, ore)

(r) Clay (in ground)

(r) Coal (in ground)

(r) Iron (Fe, ore)

(r) Limestone ( $\mathrm{CaCO}$, in ground)

(r) Natural Gas (in ground)

(r) Oil (in ground)

(r) Sand (in ground)

(r) Sodium Chloride ( $\mathrm{NaCl}$, in ground or in sea)

(r) Uranium $(U$, ore)

Aluminum Scrap

Iron Scrap

Lubricant

Trinitrotoluene (C6H3(NO2)3)

Water Used (total)

Water: Unspecified Origin

Air Emissions

(a) Aldehydes

(a) Ammonia (NH3)

(a) Carbon Dioxide (CO2, fossil)

(a) Carbon Monoxide (CO)

(a) Chlorides (Cl-)

(a) Fluorides (F-)

(a) Non-methane hydrocarbons (including VOCs

(a) Hydrogen Chloride $(\mathrm{HCl})$

(a) Hydrogen Fluoride (HF)

(a) Hydrogen Sulfide (H2S)

(a) Metals (unspecified)

(a) Methane ( $\mathrm{CH} 4)$

(a) Nitrogen Oxides (NOx as NO2)

(a) Nitrous Oxide (N2O)

(a) Organic Matter (unspecified)

(a) Particulates (unspecified)

(a) Sulfur Oxides (SOx as SO2)

(a) Tars (unspecified)

Water Emissions

(w) Acids $(\mathrm{H}+)$

(w) Ammonia (NH4t, $\mathrm{NH3}$, as N)

(w) BOD5 (Biochemical Oxygen Demand)

(w) Chlorides (Cl-)

(w) COD (Chemical Oxygen Demand)

(w) Cyanides ( $\mathrm{CN}$-)

(w) Dissolved Matter (unspecified)

(w) Fluorides (F-)

(w) Inorganic Dissolved Matter (unspecified)

(w) Iron (Fet, $\mathrm{Fe} 3+$ )

(w) Metals (unspecified)

(w) Nitrates (NO3-)

(w) Nitrogenous Matter (unspecified, as N)

(w) Oils

(w) Organic Dissolved Matter (unspecified)

(w) Phenol (C6H6O)

(w) Sodium ( $\mathrm{Na}+$ )

(w) Sulfates (SO4-)

(w) Sulfides (S-)

(w) Suspended Matter (unspecified)

(w) Tars (unspecified)

(w) Water: Chemically Polluted

Energy

Non-electric Enery Consumed

Electricity Consumed

Solid Wastes

Recovered Matter (total)

Waste (total) rail car use \% truck use \%

$99.98 \%$

$18.13 \%$

$21.69 \%$

$32.23 \%$

$32.34 \%$

$25.37 \%$

$26.36 \%$

$100.00 \%$

$87.70 \%$

$15.33 \%$

$100.00 \%$

$32.92 \%$

$16.37 \%$

$100.00 \%$

$30.68 \%$

$30.68 \%$

$26.31 \%$

$26.72 \%$

$26.25 \%$

$37.10 \%$

$100.00 \%$

$41.74 \%$

$20.70 \%$

$94.05 \%$

$71.70 \%$

$18.13 \%$

$25.81 \%$

$17.35 \%$

$27.34 \%$

$4.85 \%$

$26.30 \%$

$24.00 \%$

$55.68 \%$

$18.96 \%$

$33.60 \%$

$29.85 \%$

$26.43 \%$

$97.20 \%$

$26.35 \%$

$32.23 \%$

$26.36 \%$

$29.87 \%$

$18.55 \%$

$15.33 \%$

$19.11 \%$

$15.33 \%$

$18.13 \%$

$25.25 \%$

$18.13 \%$

$31.79 \%$

$86.54 \%$

$82.75 \%$

$32.23 \%$

$19.84 \%$

$18.96 \%$

$100.00 \%$

$26.23 \%$

$81.87 \%$

$78.31 \%$

$67.77 \%$

$67.66 \%$

$74.63 \%$

$73.64 \%$

$0.00 \%$

$12.30 \%$

$84.67 \%$

$0.00 \%$

$67.08 \%$

$83.63 \%$

$0.00 \%$

$69.32 \%$

$69.32 \%$

$73.69 \%$

$73.28 \%$

$73.75 \%$

$62.90 \%$

$0.00 \%$

$58.26 \%$

$79.30 \%$

$5.95 \%$

$28.30 \%$

$81.87 \%$

$74.19 \%$

$82.65 \%$

$72.66 \%$

$95.15 \%$

$73.70 \%$

$76.00 \%$

$44.32 \%$

$81.04 \%$

$66.40 \%$

$70.15 \%$

$73.57 \%$

$2.80 \%$

$73.65 \%$

$67.77 \%$

$73.64 \%$

$70.13 \%$

$81.45 \%$

$84.67 \%$

$80.89 \%$

$84.67 \%$

$81.87 \%$

$74.75 \%$

$81.87 \%$

$68.21 \%$

$13.46 \%$

$17.25 \%$

$67.77 \%$

$80.16 \%$

$81.04 \%$

$0.00 \%$

$73.77 \%$

$80.07 \%$

MJ elec $\quad 19.93 \%$ 
Figure 27: A Breakdown of Plant Construction CO2 Air Emissions

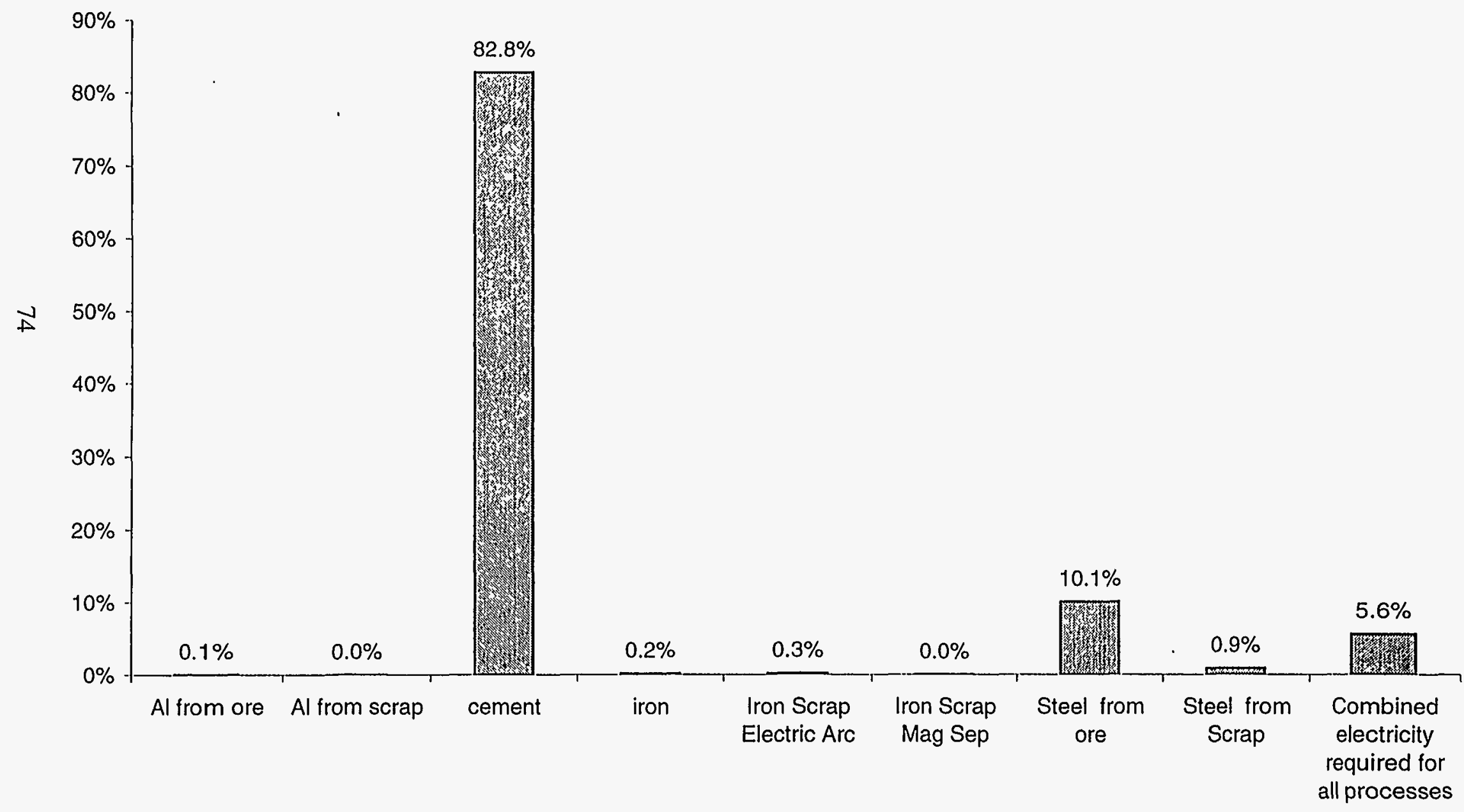


Table 27: Plant Construction Emissions

\section{Aldehydes}

Ammonia (NH3)

Carbon Dioxide (CO2)

Carbon Monoxide (CO)

Chlorides (Cl-)

Fluorides (F-)

Non-methane hydrocarbons (including VOCs)

Hydrogen Chloride $(\mathrm{HCl})$

Hydrogen Fluoride (HF)

Hydrogen Sulfide (H2S)

Metals (unspecified)

ù

Nitrogen Oxides (NOx as NO2)

Nitrous Oxide (N2O)

Organic Matter (unspecified)

Particulates (unspecified)

Sulfur Oxides (SOx as SO2)

Tars (unspecified)

BOD5 (Biochemical Oxygen Demand)

COD (Chemical Oxygen Demand)

Total Primary Energy

Electricity

Iron Scrap Electric Arc = detinnin

Iron Scrap Mag Sep $=$ magnetic separation of steel scrap from mixed waste
Percentages greater than $30 \%$ are shaded in gray.

\section{Combined}

Iron

Scrap Iron Steel electricity

Electric Scrap Steel from

Mag Sep from ore Scrap

quired for

ore

scrap

cement iron

$4.05 \%$

$0.24 \% \quad 48.85 \%$

$0.02 \% 9621 \%$

$0.03 \% \quad 10.06 \%$

$0.01 \% \quad 6.73 \%$

$0.00 \% \quad 0.00 \%$

$0.00 \% \quad 0.00 \%$

$0.08 \%, 57.45 \%$

$0.00 \% \quad 0.00 \%$

$0.00 \% \quad 16.55 \%$

$0.00 \%$

$0.00 \% \quad 0.00 \% \quad 28.61 \%$

$3.87 \% \quad 57869 \% \quad 7.34 \%$

$0.02 \% \quad 2.58 \% \quad 0.83 \%$

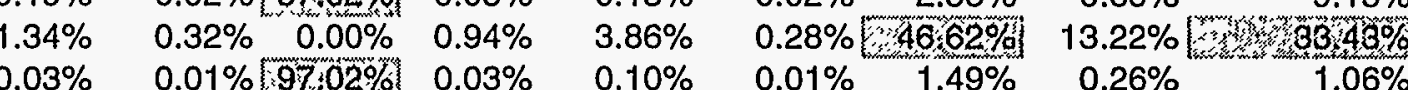

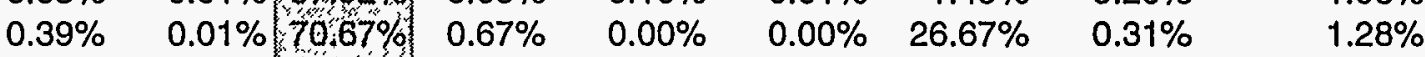

$\begin{array}{lllllllll}0.55 \% & 0.09 \% & 63.59 \% & 0.20 \% & 0.26 \% & 0.02 \% & 10.07 \% & 2.52 \% & 22.71 \%\end{array}$

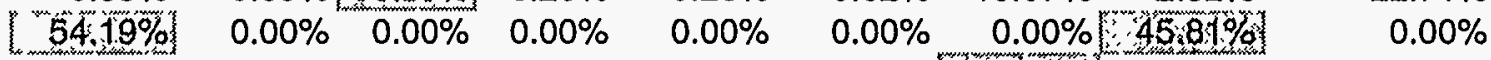

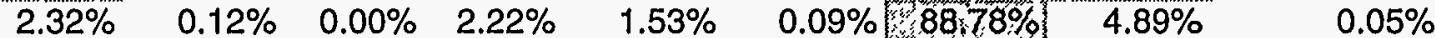

$\begin{array}{lllll}25.82 \% & 0.92 \% & 0.00 \% & 0.06 \% & 11.30 \%\end{array}$

$0.67 \% \quad 16.80 \%$ \% $44.09 \%$ $0.35 \%$

$0.18 \%$, $66.38 \% \quad 5.27 \%$ W $0.52 \% \quad 4.91 \%$ $0.57 \% 31.62 \% \% 52 \%$

$9.49 \% \quad 0.64 \% \quad 0.52 \%$

$4.91 \% \quad 0.57 \%$ 


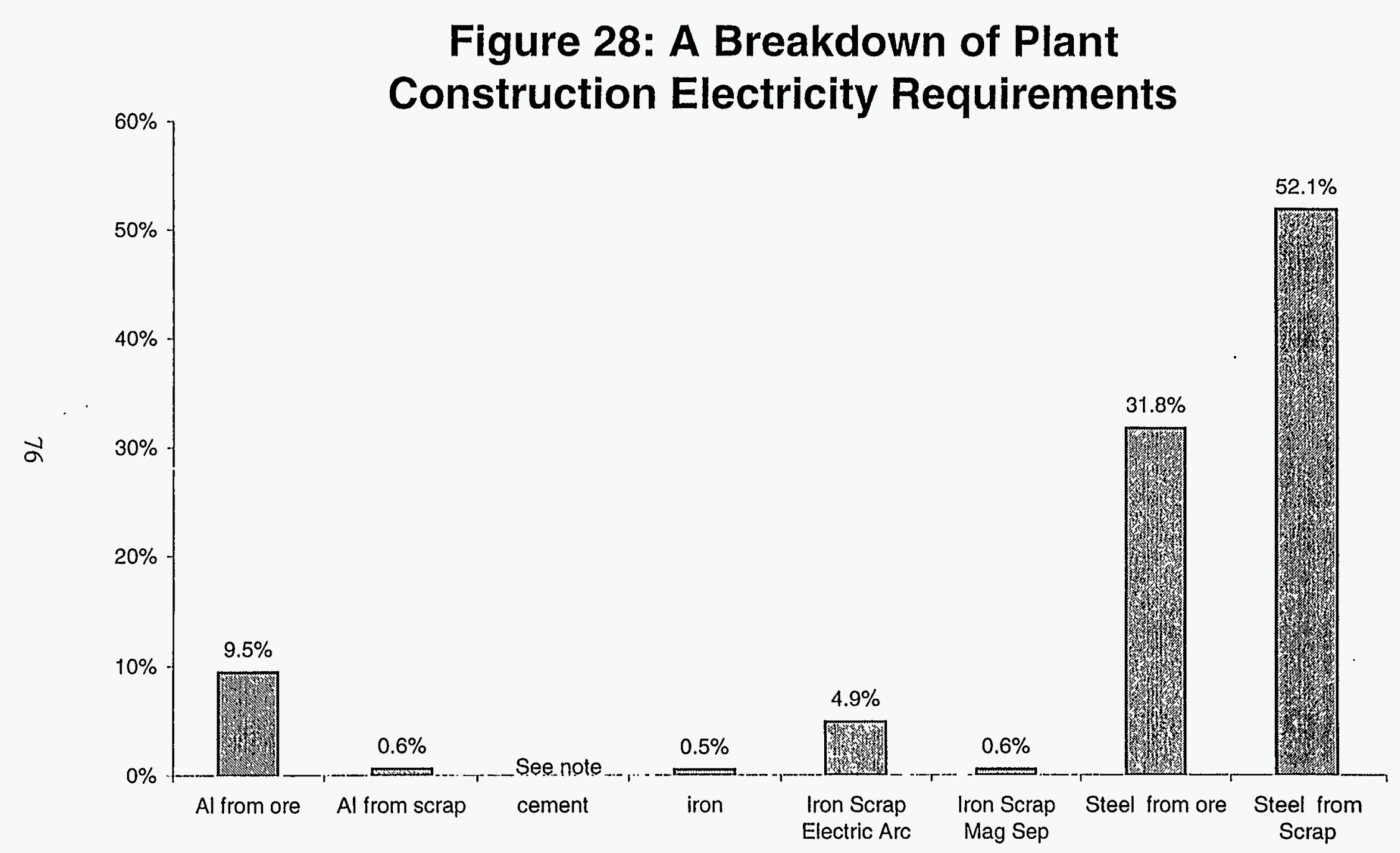

Note: Total energy requirements for cement are shown on Figure 29;

data available do not distinguish between electric and non-electric energy requirements. 


\section{Figure 29: A Breakdown of Non-electric Energy Requirements for Plant Construction}

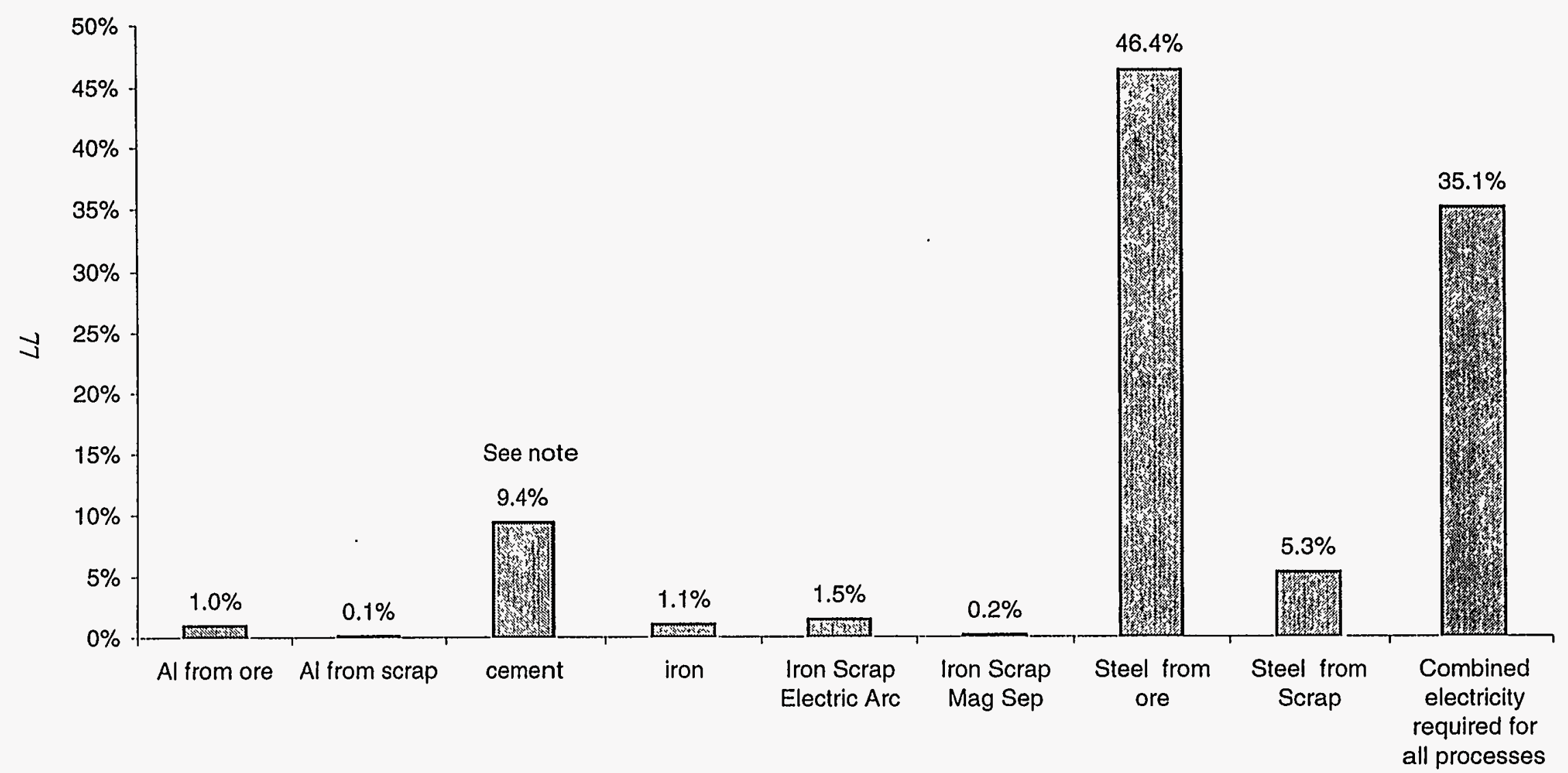

Note: Energy requirements shown for cement include both electric and non-electric energy requirements; data available do not distinguish between these two types of energy. 
Construction and demolition wastes will be produced in power plant construction and can be sent to a municipal solid waste landfill. Methane and $\mathrm{CO}_{2}$ are the primary emissions from the landfill, produced by microorganisms under anaerobic conditions. At the end of the power plant's life, $75 \%$ of the materials of construction are recycled and $25 \%$ are landfilled. The recycling of materials is handled in the same manner as that described above under transportation (section 4.2).

In many of the previous figures, it is evident that some of the emissions in the two construction years are considerably higher than the average emissions over the life of the system. Table 28 contains a comparison of the construction emissions versus the total emissions in years negative one and negative two. The construction emissions are by far the majority of the emissions in these two years. However, it should be emphasized that the environment sees the emissions in the years that construction actually occurs and that these emissions are overshadowed by the feedstock, transportation, and operating emissions when summed up over the life of the system.

Table 28: Comparison of Construction and Total Emissions in Years -1 and -2

\begin{tabular}{|l|c|c|c|}
\hline & $\begin{array}{l}\text { Construction emissions } \\
\text { averaged over 2 years }\end{array}$ & $\begin{array}{c}\text { Total emissions } \\
\text { during the construction years } \\
\text { averaged over 2 years }{ }^{(b)}\end{array}$ & $\begin{array}{c}\text { Construction emissions as a } \\
\text { percent of the total emissions } \\
\text { in years -1 and -2 }\end{array}$ \\
\hline & $(\mathrm{Mg} / \mathrm{yr})$ & $(\mathrm{Mg} / \mathrm{yr})$ & $(\%)$ \\
\hline $\mathrm{NO}_{\mathrm{x}}$ & 113 & 185 & $61 \%$ \\
\hline $\mathrm{SO}_{\mathrm{x}}$ & 103 & 105 & $98 \%$ \\
\hline $\mathrm{CH}_{4}$ & 0.6 & 3.4 & $18 \%$ \\
\hline $\mathrm{CO}$ & 32 & 63 & $50 \%$ \\
\hline particulates & 147 & 170 & $86 \%$ \\
\hline $\mathrm{HC}$ (except CH & & $78 \%$ \\
\hline $\begin{array}{l}\text { Explanation of table } \\
\text { (a) (construction emissions in year negative two plus construction emissions in year negative one)/two } \\
\text { (b) (feedstock and construction emissions in year negative two plus feedstock and construction emissions in } \\
\text { year negative one)/two } \\
\text { (O) column (a)/ column (b) }\end{array}$ & 74 & 95 & \\
\hline
\end{tabular}

\subsection{Base Case Power Generation Results}

Although most of the resources consumed by the system are used in feedstock production, a significant amount is used in constructing the power plant. The bulk of the air and water emissions also come from the feedstock production subsystem. However, the power plant emits the vast majority of NOx, SOx, and VOCs. Details on stressors specific to the power plant are given in previous sections. 


\subsection{Sensitivity Analysis}

A sensitivity analysis was conducted to identify the parameters that had the largest effects on the results of the study and to minimize the impact of incorrect data on the conclusions. Each parameter was changed independent of all others so that the magnitude of its effect on the base case could be assessed. One variable may affect several factors and thus several process steps or it may affect only one block in the overall life cycle assessment. For instance, changing the biomass yield affects the acreage required to grow the biomass, which in turn affects the amount of fertilizer, pesticides, and herbicides used, and the average distance to deliver the biomass to the plant. However, varying the amount of materials used to build the power plant affects only the emissions associated with plant construction and decommissioning. These affects were taken into account automatically in the LCA model.

Most of the sensitivity cases are shown in Table 29. Additionally, the amount of materials used to construct the power plant was reduced by $25 \%$ (case L), the distance that the biomass was transported was increased by $46 \%$ (case $M$ ), and the amount of materials recycled after decommissioning was decreased by one-third (case $\mathrm{N}$ ).

A summary of the effects on the major emissions, energy use, and resource consumption relative to the base case for several of the parameters varied is shown in Table 30. The percentages shown represent the deviation from the base case values when comparing the results on a per unit of energy produced (i.e., $M W h$ ) basis. The positive numbers indicate a percent increase while the negative numbers signify a decrease. The cases that had little effect on the life cycle assessment results are excluded from this table but are discussed in the following text. For easier interpretation, Figures 30 and 31 are graphical representations of the $\mathrm{CO}_{2}$ and energy sensitivity results. The sensitivity cases that result in the largest change from the base case values are highlighted in these figures. 
Table 29: Sensitivity Analysis Cases

\begin{tabular}{|c|c|c|c|c|c|c|c|}
\hline Parameter & Base Case & Low Case & $\begin{array}{l}\text { Case } \\
\text { Letter }\end{array}$ & $\begin{array}{l}\text { \% Change } \\
\text { from Base Case }\end{array}$ & High Case & $\begin{array}{l}\text { Case } \\
\text { Letter }\end{array}$ & $\begin{array}{l}\text { \% Change } \\
\text { from Base Case }\end{array}$ \\
\hline Yicld (bone dry Mg/ha/yr) & 13.5 & 9.0 & A & $-33.3 \%$ & 15.7 & B & $16.3 \%$ \\
\hline $\begin{array}{l}\text { Amount of nitrogen fertilizer } \\
\text { applied (kg nitrate/ha) }\end{array}$ & 100 in year 4 & 56 in year 4 & C & $-44 \%$ & 100 in years 2,4 , and 6 & D & $200 \%$ \\
\hline $\begin{array}{l}\text { Amount of phosphorus } \\
\text { fertilizer applied (kg P/ha) }\end{array}$ & 22 in year 1 & 0 & $\mathrm{E}$ & $-100 \%$ & 44 in year 1 & F & $100 \%$ \\
\hline $\begin{array}{l}\text { Amount of potassium } \\
\text { fertilizer applied (kg K/ha) }\end{array}$ & 39 in year 1 & 0 & G & $-100 \%$ & 56 in year 1 & $\mathrm{H}$ & $43.6 \%$ \\
\hline $\begin{array}{l}\text { Type of nitrogen fertilizer } \\
\text { applied }\end{array}$ & $\begin{array}{l}50 \% \text { ammonium nitrate, } \\
50 \% \text { urea }\end{array}$ & $100 \%$ Uren & J & $\mathrm{N} / \mathrm{A}$ & $100 \%$ Ammonium nitratc & 1 & N/A \\
\hline $\begin{array}{l}\text { Amount of herbicide applied } \\
\left(\mathrm{cm}^{3} / \mathrm{ha}\right)\end{array}$ & 36.5 in years 1 and 2 & 36.5 in years 1 and 2 & $\begin{array}{l}\text { Same } \\
\text { as } \\
\text { base } \\
\text { case }\end{array}$ & $0 \%$ & 54.75 in years 1 and 2 & K & $50 \%$ \\
\hline $\begin{array}{l}\text { Amount of fossil fuel use in } \\
\text { fecdstock production }\end{array}$ & $\begin{array}{l}\text { Average of } 82.8 \\
\text { liters/ha/yr }\end{array}$ & $\begin{array}{l}\text { Average of } 49.7 \\
\text { liters } / \mathrm{ha} / \mathrm{yr}\end{array}$ & 0 & $-40 \%$ & $\begin{array}{l}\text { Average of } 124.2 \\
\text { liters/ha/yr }\end{array}$ & $\mathbf{P}$ & $50 \%$ \\
\hline Power plant efficiency & $37.2 \%$ & $32.2 \%$ & $Q$ & $\begin{array}{l}-5 \text { percentage } \\
\text { points }\end{array}$ & $42.2 \%$ & $\mathrm{R}$ & $\begin{array}{l}5 \text { percentage } \\
\text { points }\end{array}$ \\
\hline $\begin{array}{l}\text { Power plant operating } \\
\text { capacity }\end{array}$ & $\begin{array}{l}40 \% \text { in year } 1, \\
80 \% \text { in years } 2-29, \\
60 \% \text { in year } 30\end{array}$ & $\begin{array}{l}32.5 \% \text { in year } 1,65 \% \\
\text { in years } 2-29,48.75 \% \\
\text { in year } 30\end{array}$ & $S$ & $\begin{array}{l}-15 \text { percentage } \\
\text { points in } \\
\text { normal } \\
\text { operating } \\
\text { years }\end{array}$ & $\begin{array}{l}42.5 \% \text { in year } 1,85 \% \\
\text { in years } 2-29,63.75 \% \\
\text { in year } 30\end{array}$ & $\mathrm{~T}$ & $\begin{array}{l}5 \text { percentage } \\
\text { points in } \\
\text { normal } \\
\text { operating } \\
\text { years }\end{array}$ \\
\hline
\end{tabular}

Note: The case letters in this table correspond to the letters in Table 30 and Figures 30-34. 
Table 30: Sensitivity Analysis Condensed Results

$\%$ change from the base case (on a per unit of energy (e.g., MWh) produced basis)

\begin{tabular}{|c|c|c|c|c|c|c|c|c|c|c|c|c|c|c|c|c|c|c|c|c|}
\hline r: Coal & $\begin{array}{c}A \\
34.2 \%\end{array}$ & $\begin{array}{c}B \\
-9.8 \%\end{array}$ & $\begin{array}{c}C \\
-10.7 \%\end{array}$ & $\begin{array}{c}D \\
109.0 \%\end{array}$ & $\begin{array}{c}E \\
-12.9 \%\end{array}$ & $\begin{array}{c}F \\
12.9 \%\end{array}$ & $\begin{array}{c}G \\
-17.1 \%\end{array}$ & $\begin{array}{l}\mathrm{H} \\
7.3 \%\end{array}$ & $\begin{array}{l}1 \\
2.5 \%\end{array}$ & $\begin{array}{l}\mathrm{J} \\
-2.5 \%\end{array}$ & $\begin{array}{l}\mathrm{K} \\
0.2 \%\end{array}$ & $\begin{array}{c}L \\
-27.9 \%\end{array}$ & $\begin{array}{l}\bar{M} \\
0.7 \%\end{array}$ & $\begin{array}{l}N \\
4.3 \%\end{array}$ & $\begin{array}{l}0 \\
-1.4 \%\end{array}$ & $\begin{array}{l}P \\
1.1 \%\end{array}$ & $\begin{array}{c}\mathbf{Q} \\
15.5 \%\end{array}$ & $\begin{array}{c}R \\
-11.8 \%\end{array}$ & $\begin{array}{l} \\
7.8 \%\end{array}$ & $\begin{array}{c}T \\
-2.0 \%\end{array}$ \\
\hline r: Natural gas & $47.9 \%$ & $-13.7 \%$ & $-37.2 \%$ & $176.2 \%$ & $-1.5 \%$ & $1.5 \%$ & $-2.0 \%$ & $0.9 \%$ & $23.3 \%$ & $-23.3 \%$ & $0.2 \%$ & $-2.9 \%$ & $1.3 \%$ & $0.6 \%$ & $-2.7 \%$ & $2.2 \%$ & $15.5 \%$ & $-11.8 \%$ & $1.9 \%$ & $-0.5 \%$ \\
\hline r: Oil & $43.6 \%$ & $-12.7 \%$ & $-0.3 \%$ & $2.9 \%$ & $-0.3 \%$ & $0.3 \%$ & $-0.4 \%$ & $0.2 \%$ & $0.1 \%$ & $-0.1 \%$ & $0.0 \%$ & $-0.5 \%$ & $18.3 \%$ & $0.0 \%$ & $-38.7 \%$ & $31.0 \%$ & $15.5 \%$ & $-11.8 \%$ & $1.1 \%$ & $-0.3 \%$ \\
\hline a: $\mathrm{CO} 2$ & $15.9 \%$ & $-4.6 \%$ & $-0.9 \%$ & $7.2 \%$ & $-0.7 \%$ & $0.7 \%$ & $.0 .9 \%$ & $0.4 \%$ & $0.6 \%$ & $-0.6 \%$ & $0.0 \%$ & $-7.0 \%$ & $5.5 \%$ & $0.2 \%$ & $-12.7 \%$ & $10.1 \%$ & $15.5 \%$ & $-11.8 \%$ & $0.5 \%$ & $-1.7 \%$ \\
\hline a: CO & $43.3 \%$ & $-12.5 \%$ & $-1.5 \%$ & $8.6 \%$ & $-0.4 \%$ & $0.4 \%$ & $-0.5 \%$ & $0.2 \%$ & $-0.1 \%$ & $0.1 \%$ & $0.0 \%$ & $-3.2 \%$ & $12.8 \%$ & $0.0 \%$ & $-38.1 \%$ & $30.5 \%$ & $15.5 \%$ & $-11.8 \%$ & $1.8 \%$ & $-0.5 \%$ \\
\hline a: NMHC (including VOCs) & $5.8 \%$ & $-1.7 \%$ & $-0.6 \%$ & $4.5 \%$ & $-0.4 \%$ & $0.4 \%$ & $-0.5 \%$ & $0.2 \%$ & $0.2 \%$ & $-0,2 \%$ & $0.0 \%$ & $.0 .8 \%$ & $1.2 \%$ & $0.1 \%$ & $-4.2 \%$ & $3.4 \%$ & $15.5 \%$ & $-11.8 \%$ & $0.3 \%$ & $-0.1 \%$ \\
\hline a: $\mathrm{CH}_{4}$ & $45.3 \%$ & $-13.0 \%$ & $-20.1 \%$ & $93.0 \%$ & $-0.4 \%$ & $0.4 \%$ & $-0.6 \%$ & $0.2 \%$ & $4.4 \%$ & $-4.4 \%$ & $0.1 \%$ & $-0.7 \%$ & $4.0 \%$ & $0.2 \%$ & $-20.9 \%$ & $16.7 \%$ & $15.5 \%$ & $-11.8 \%$ & $1.3 \%$ & $-0.3 \%$ \\
\hline a: NOX & $13.0 \%$ & $-3.8 \%$ & $-0.2 \%$ & $1.2 \%$ & $-0.1 \%$ & $0.1 \%$ & $-0.1 \%$ & $0.1 \%$ & $0.1 \%$ & $-0.1 \%$ & $0.0 \%$ & $-1.4 \%$ & $3.8 \%$ & $0.0 \%$ & $-11.8 \%$ & $9.5 \%$ & $15.5 \%$ & $-11.8 \%$ & $0.6 \%$ & $-0.2 \%$ \\
\hline a: Particulate matter & $29.9 \%$ & $-8.7 \%$ & $-5.2 \%$ & $45.9 \%$ & $-4.5 \%$ & $4.5 \%$ & $-6.0 \%$ & $2.6 \%$ & $4.4 \%$ & $-4.4 \%$ & $0.0 \%$ & $-24.2 \%$ & $7.4 \%$ & $3.0 \%$ & $-15.8 \%$ & $12.7 \%$ & $15.5 \%$ & $-11.8 \%$ & $6.6 \%$ & $-1.7 \%$ \\
\hline a: SO $x$ & $5.8 \%$ & $-1.7 \%$ & $-0.4 \%$ & $4.0 \%$ & $-0.4 \%$ & $0.4 \%$ & $-0.6 \%$ & $0.2 \%$ & $0.1 \%$ & $-0.1 \%$ & $0.0 \%$ & $-2.8 \%$ & $2.1 \%$ & $0.0 \%$ & $-4.1 \%$ & $3.3 \%$ & $15.5 \%$ & $-11.8 \%$ & $0.7 \%$ & $-0.3 \%$ \\
\hline w: NH4+ & $50.0 \%$ & $-14.3 \%$ & $-44.4 \%$ & $199.8 \%$ & $0.0 \%$ & $0.0 \%$ & $0.0 \%$ & $0.0 \%$ & $100.0 \%$ & $-100.0 \%$ & $0.0 \%$ & $0.0 \%$ & $0.0 \%$ & $0.0 \%$ & $0.0 \%$ & $0.0 \%$ & $15.5 \%$ & $-11.8 \%$ & $1.2 \%$ & $-0.3 \%$ \\
\hline w: Dissolved matter & $43.7 \%$ & $-12.7 \%$ & $\cdot 0.2 \%$ & $2.2 \%$ & $-0.3 \%$ & $0.3 \%$ & $-0.3 \%$ & $0.1 \%$ & $0.1 \%$ & $-0.1 \%$ & $0.0 \%$ & $-0.3 \%$ & $18.4 \%$ & $0.0 \%$ & $-38.9 \%$ & $31.2 \%$ & $15.5 \%$ & $-11.8 \%$ & $1.1 \%$ & $-0.3 \%$ \\
\hline Energy consumption & $41.8 \%$ & $-12.1 \%$ & $-3.3 \%$ & $23.6 \%$ & $-1.8 \%$ & $1.8 \%$ & $-2.4 \%$ & $1.0 \%$ & $1.5 \%$ & $-1.5 \%$ & $0.0 \%$ & $-3.8 \%$ & $15.0 \%$ & $0.5 \%$ & $-31.8 \%$ & $25.5 \%$ & $15.5 \%$ & $-11.8 \%$ & $1.8 \%$ & $-0.5 \%$ \\
\hline Solld Waste & $30.6 \%$ & $-8.7 \%$ & $-8.5 \%$ & $87.2 \%$ & $-10.4 \%$ & $10.4 \%$ & $-13.8 \%$ & $5.9 \%$ & $2.5 \%$ & $-2.5 \%$ & $0.1 \%$ & $-34.6 \%$ & $0.2 \%$ & $27.3 \%$ & $-0.4 \%$ & $0.3 \%$ & $15.5 \%$ & $-11.8 \%$ & $9.3 \%$ & $-2.4 \%$ \\
\hline
\end{tabular}

$r=$ resource

$a=$ air emission

$w=$ water emission

Yieid of 9 Dn Tonnes / Hectare / Year (4 tons/acre/yr)

Yield of 15.7 Dry Tonnes / Hectare / Year (7 tons/acre/yr)

Nitrogen Fertilizer Low Case

Nitrogen Fertllizer High Case

Phosphorous Fertilizer Low Case

Phosphorous Fertilizer High Case

Potassium Fertilizer Low Case

Potassium Fertilizer High Case

Ammonium Nitrate as Sole Nitrogen Fertilizer

Urea as Sole Nitrogen Fertilizer

Herbicide Application High Case

Construction Materials Low Case

Biomass Transportation Distance Increased by $46 \%$

Decrease in Recycle of Materials by $1 / 3$

Decrease in Feedstock Fuel Use by $50 \%$

Increase in Feedstock Fuel Use by $40 \%$

Decrease plant efficiency by 5 points

Increase plant efficiency by 5 points

Plant operating capcity lactor $=65 \%$ in normal years

Plant operaling capcity factor $=85 \%$ in normal years 


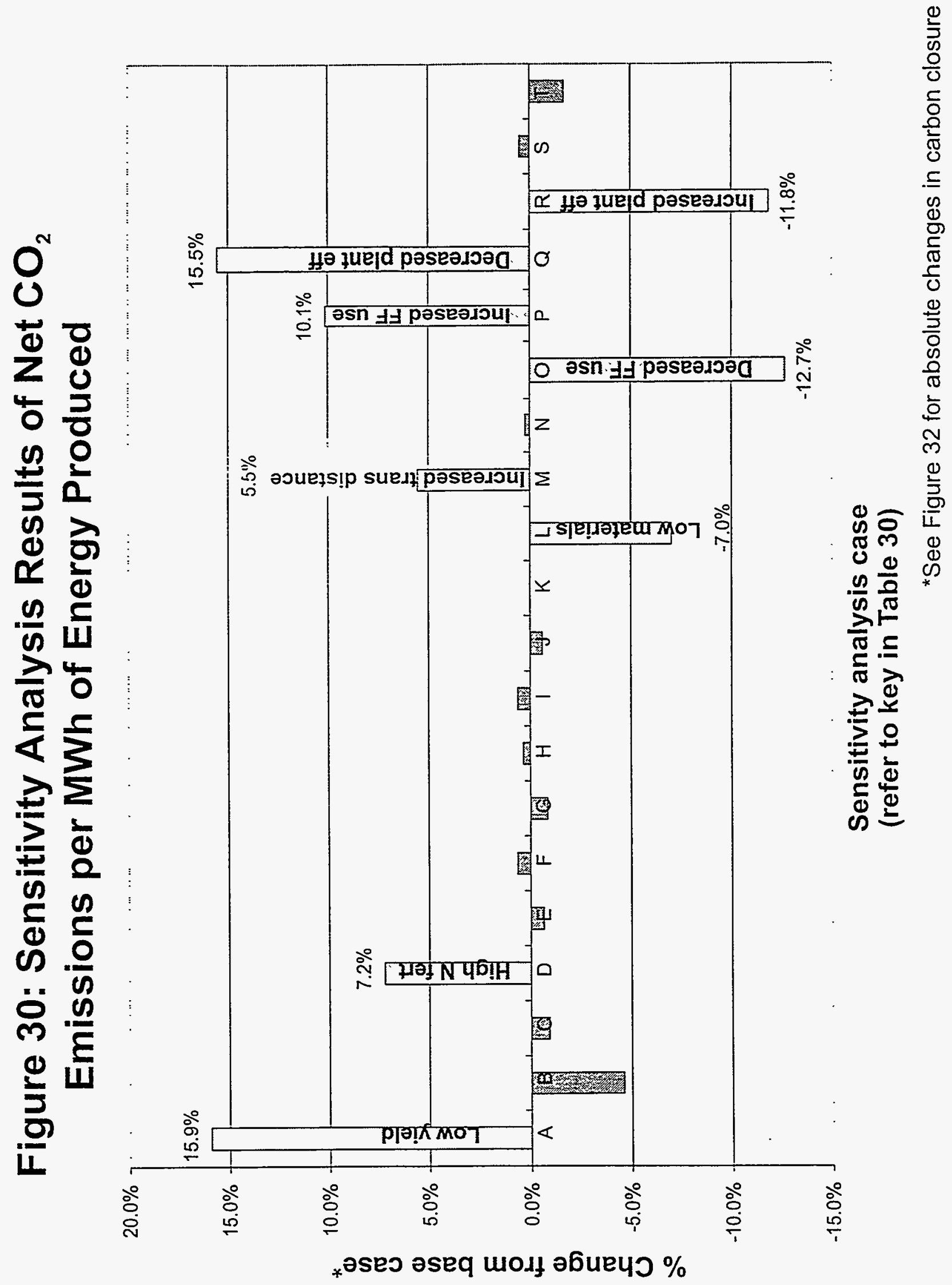




\section{Figure 31: Sensitivity Analysis Results of System Energy Consumption per MWh of Energy Produced}

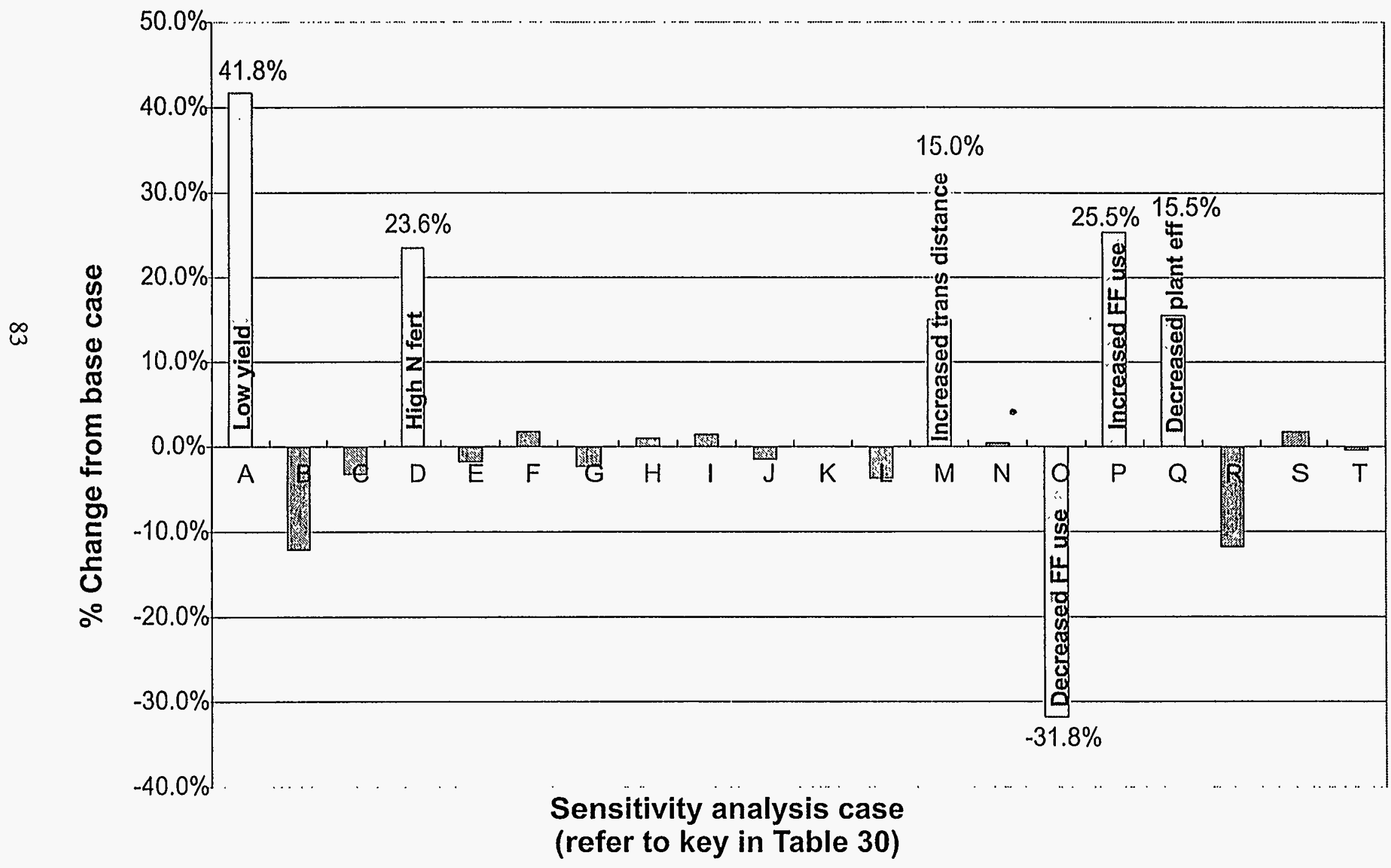

*See Figures 33 and 34 for absolute changes in energy measures 
Figure 32 shows the effect of the sensitivity cases on carbon closure, defined to be the amount of $\mathrm{CO}_{2}$ emitted to the atmosphere divided by that recycled to the biomass. Additional cases, showing the carbon closure as a function of the amount of carbon sequestered in the soil, were given in Figure 8. Effects on the life cycle efficiency and fossil fuel energy ratio (see section 5.3) are shown in Figures 33 and 34. It's important to note that the scales shown on Figures 32 and 33 (carbon closure and life cycle efficiency) are very narrow, indicating that for even the most drastic values of the parameters changed, the overall results of the study remain the same. That is, carbon closure is very high (greater than 94\%) and the life cycle efficiency is not significantly less than the power plant efficiency. Additionally, the fossil fuel energy ratio does not drop below 11, indicating that the amount of energy the system produces as electricity will always be significantly greater than the fossil energy it consumes.

\subsection{Feedstock Sensitivity Analysis}

Of the parameters related to feedstock production, lowering the yield by one-third has the largest effect on the results, causing a $16 \%$ increase in $\mathrm{CO}_{2}$ emissions and a $42 \%$ increase in system energy consumption. Additionally, yield most affects carbon closure (94\%) and the fossil fuel energy ratio (11). As expected, changing the amount of fossil fuel used in farming operations had a large impact in relation to the base case results. However, as noted above, carbon closure and life cycle efficiency are still very high.

The amount of fertilizers applied also has a large effect on emissions and energy consumption. In particular, nitrogen fertilizer, used at the rate in the high case, will increase overall system energy consumption by nearly $24 \%$, and increase overall $\mathrm{CO}_{2}$ emissions by $7 \%$. Although it was found that using only ammonium nitrate or urea to supply nitrogen to the soil will affect some emissions and resources, the overall effect on energy and $\mathrm{CO}_{2}$ is small. Increasing the amount of herbicide applied has very little impact on overall emissions and energy use.

\subsection{Transportation Sensitivity Analysis}

\subsubsection{Mode of Transportation}

The split of wood transported by truck and train was varied in the sensitivity analysis. For the high train transport case, the percentage of wood carried by truck was decreased from $70 \%$ to $50 \%$ with the remaining $50 \%$ of the wood being delivered by train. The low case examined wood transport solely by trucks. Having a case of all-truck transport is a reasonable assumption since many of today's existing biomass power plants use trucks only. In both of these cases, since the truck and rail transport is such a small portion of the overall resources required, energy used, and emissions generated, the distribution of the type of transport does not have a large effect on the overall life cycle assessment. For the 50\% truck and 50\% train transport case the average decrease in resources, energy, and emissions from the transportation sector was $12 \%$ but overall this made a difference of 


\section{Figure 32: Sensitivity Analysis Results for Carbon Closure}

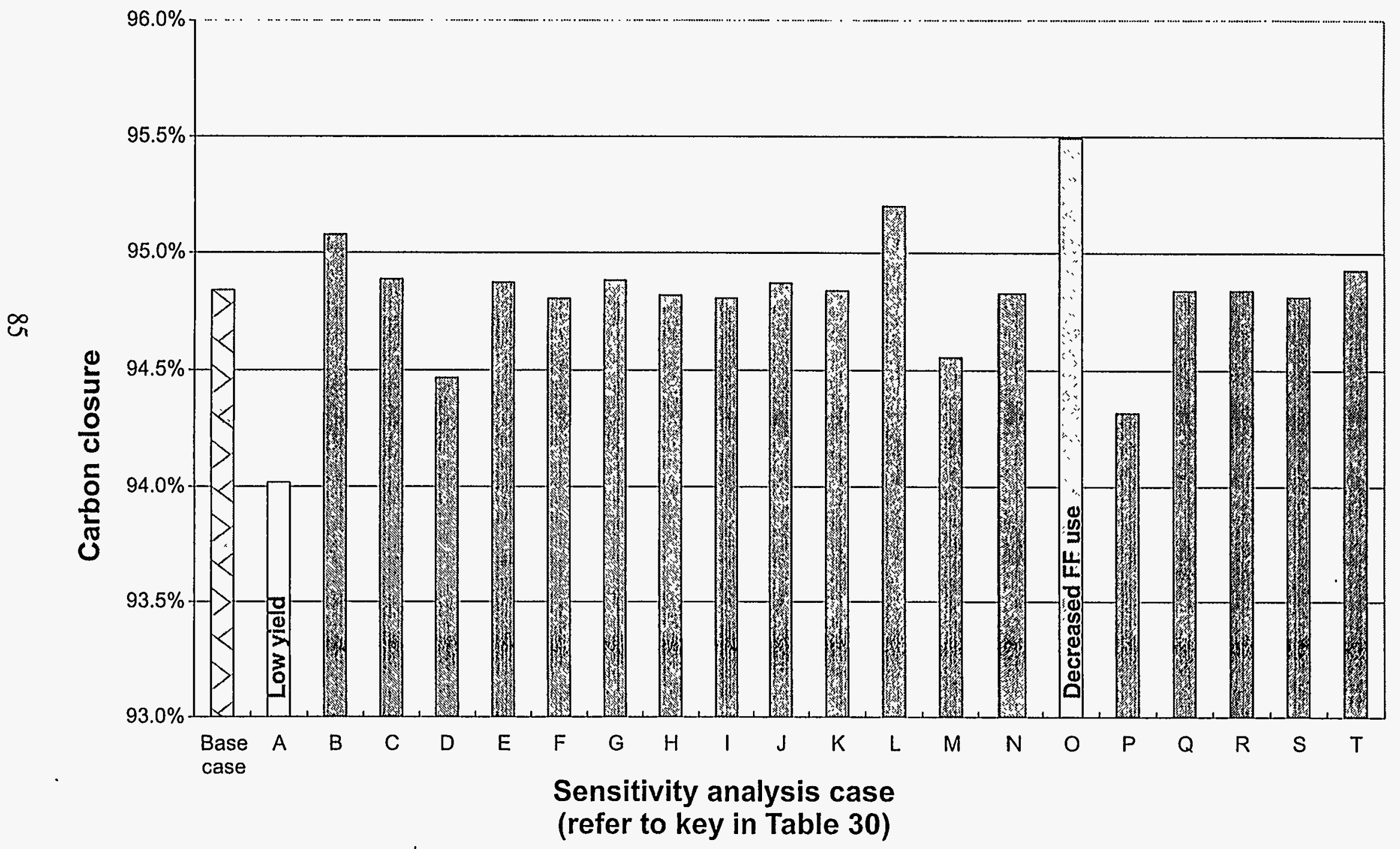




\section{Figure 33: Sensitivity Results for Life Cycle Efficiency}

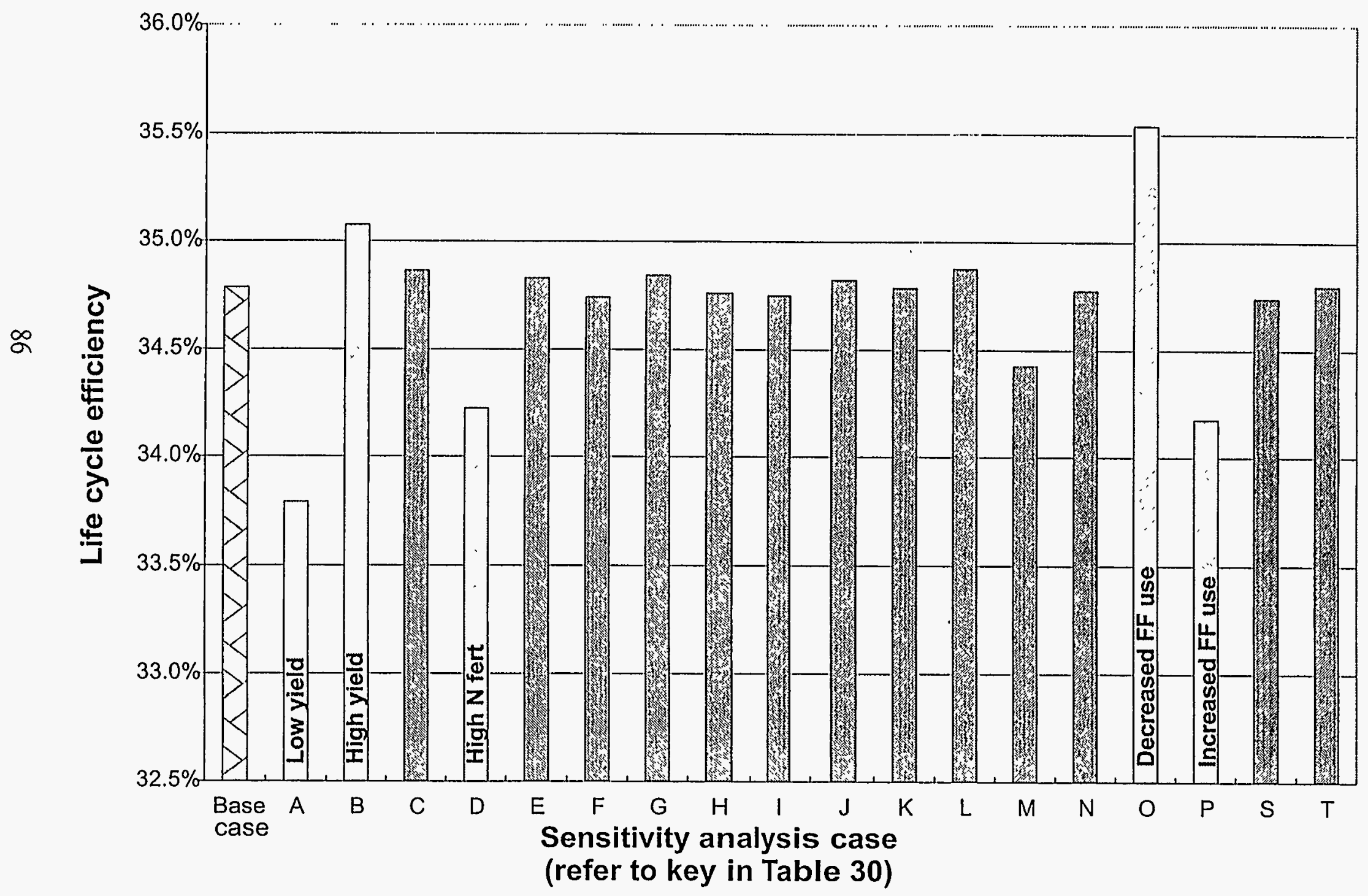




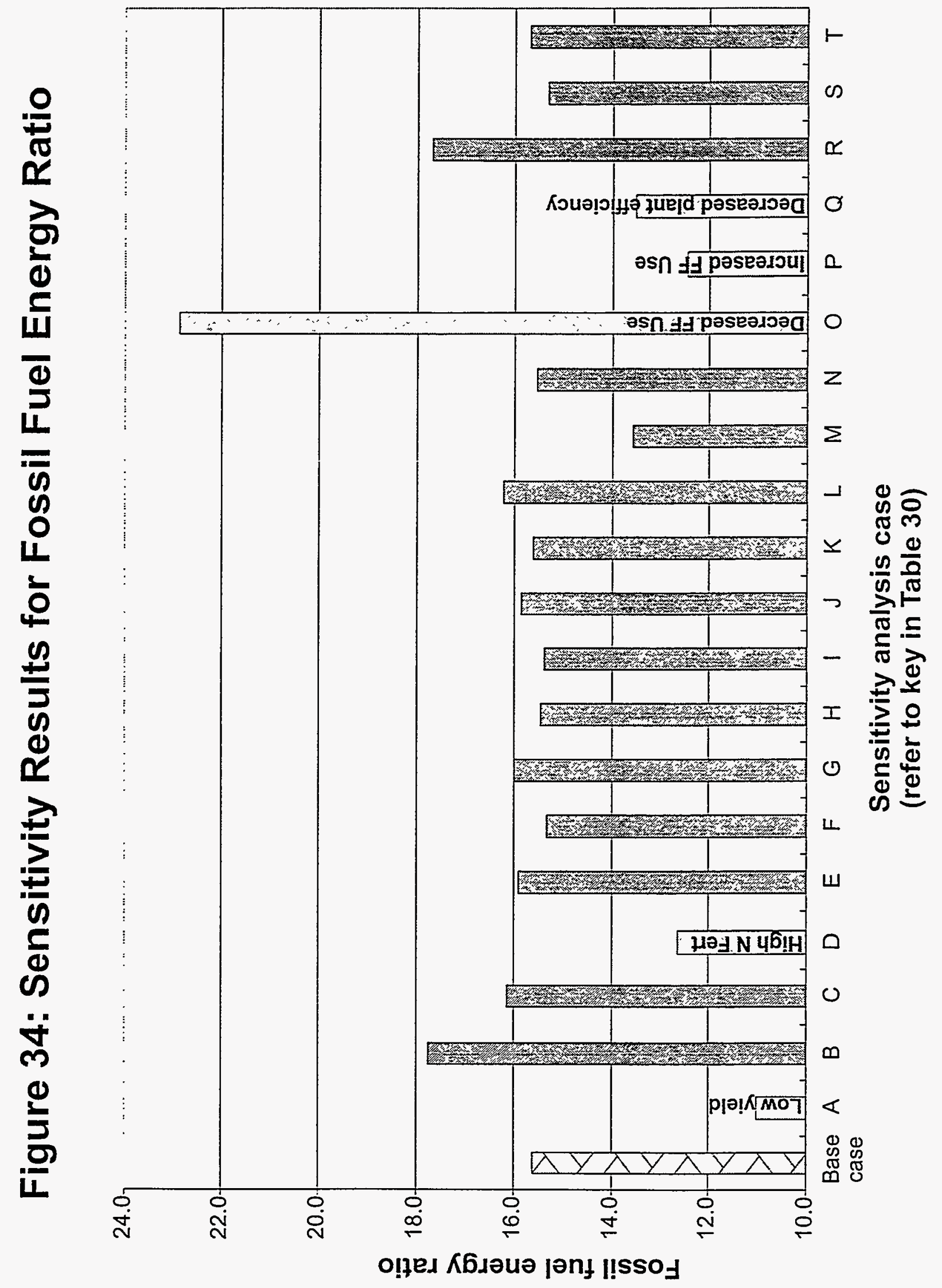


less than $2 \%$ in the overall life cycle assessment. On the same note, even though train transport is more efficient, the $100 \%$ truck case increased the resources, energy, and emissions in the overall analysis by less than $2 \%$.

\subsubsection{Transportation Distance}

Another variable examined was the average biomass transportation distance to the plant. In the base case, the average distance traveled, $27.6 \mathrm{~km}$, was calculated based on the assumption that $10 \%$ of the land around the power generation facility was available for crop production and that the land had a tortuosity factor of 1.3. In order to determine the effect of varying the percent of the land around the power generation facility available for crop production and varying the tortuosity factor, a separate test was conducted. A matrix was set up and the percent of the land around the power generation facility available for crop production was varied from 10-25\% and the tortuosity factor was varied from 1.0-2.0. The average haul distance ranged from 13.4 to $42.5 \mathrm{~km}$. As would be expected the oil consumption increases for the high case, and thus the amount taken from the ground goes up by $18 \%$ for the overall analysis. Air emissions of $\mathrm{CH}_{4}, \mathrm{NOx}$, and $\mathrm{CO}_{2}$ increase by less than $6 \%$, while particulate matter and $\mathrm{CO}$ increase by $7 \%$ and $13 \%$, respectively. System energy consumption increases by $15 \%$. Further evidence of the effect on the overall system impacts can be seen in Table 30. To minimize the environmental effects the biomass should be grown within a reasonable distance from the plant and not hauled over a distance several states away.

\subsection{Power Plant Construction \& Decommissioning Sensitivity Analysis}

Because there were two literature sources containing very different plant construction material requirements, the material requirements for concrete, steel, aluminum and iron were varied in one of the sensitivity analyses. The variation in these numbers can be seen in Table 31 . The larger numbers were used as the base case for this analysis for several reasons. In both studies the IGCC plant had an operating capacity similar to the BIGCC in this life cycle assessment; however, the study with the larger numbers was specifically for a biomass plant whereas the other study was for a coal plant. Also, the study with the higher numbers was more rigorous, being derived from an indepth report that examined the material requirements for many different operating systems (U.S. Department of Energy, 1983).

Table 31: Plant Material Requirements Used in Sensitivity

\begin{tabular}{|l|c|c|}
\hline \multicolumn{1}{|c|}{ Material } & Base case $(\mathrm{kg} / \mathrm{GWh})$ & Sensitivity $(\mathrm{kg} / \mathrm{GWh})$ \\
\hline concrete & 22,299 & 794 \\
\hline steel & 8,341 & 103 \\
\hline aluminum & 65 & 34 \\
\hline iron & 97 & 49 \\
\hline
\end{tabular}


The amount of materials used affects the emissions for both construction and decommissioning. A change in the materials of construction has a large effect on the life cycle assessment. Many of the resources decrease by over 30\% causing many of the emissions to decrease by a similar order of magnitude. Some emissions, such as $\mathrm{CO}, \mathrm{CH}_{4}, \mathrm{NMHC}$, $\mathrm{SOx}$, and $\mathrm{NOx}$, are slightly affected, with percent decreases of less than $6 \%$. The total energy requirement decreases by only $3.8 \%$.

\subsection{Landfilling versus Recycling Sensitivity Analysis}

Another sensitivity analysis involved changing the amount of materials landfilled versus recycled after disassembly of the trucks, trains, farm equipment, and power plant. The base case assumes that $75 \%$ of all materials is recycled and that the remaining $25 \%$ is landfilled. These numbers were changed to $50 \%$ each. Reducing the amount of metals recycled results in large increases in some of the resources and wastes, but has a relatively minor effect on energy requirements and most of the emissions.

\subsection{Power Generation Sensitivity Analysis}

\subsubsection{NOx Produced}

Most of the operating plant emissions are set by material balances from the ASPEN Plus ${ }^{\mathrm{TM}}$ simulation, and are not likely to vary significantly in an actual plant. However, NOx can be produced by two different mechanisms (formation of fuel-bound NOx and thermal NOx), making the possible range much broader. For the base case, it was very conservatively assumed that all of the nitrogen in the biomass was converted to NOx and emitted to the atmosphere from the stack. Because thermal NOx is difficult to predict, a sensitivity case assuming that the amount formed will be equal to the fuel NOx was run. This was based on the variation shown in the literature (Dyncorp, 1995, Delucchi, 1993, and U.S. EPA, 1995). Because $71.8 \%$ of the NOx emissions come from the power plant subsystem, doubling the NOx emissions in each operating year increases the overall NOx in the life cycle assessment by $69.8 \%$.

\subsubsection{Power Plant Efficiency}

Another sensitivity analysis was conducted to examine both a decrease and an increase in the power plant efficiency. The base case IGCC system was found to have a power plant efficiency of $37.2 \%$ (higher heating value basis). This is defined as the fraction of energy in the feedstock to the power plant that is delivered to the grid. The power plant efficiency was changed by plus and minus five points to $42.2 \%$ and $32.2 \%$. When comparing the results on a per unit of energy produced (i.e., $\mathrm{MWh}$ ) basis, this resulted in a percent change from the base case resources, emissions, and energy of $+15.5 \%$ and $-11.8 \%$. 


\subsubsection{Operating Capacity Factor}

The amount of time that the power plant operates was also varied in the sensitivity analysis. For the low case, the power plant operating capacity factor was reduced from $80 \%$ to $65 \%$ during the normal operating years. On a per unit of energy produced basis, this resulted in an average percent increase from the base case resources, emissions, and energy of $+6.3 \%$. For the high case, the operating capacity factor was increased from $80 \%$ to $85 \%$, resulting in an average decrease of about $1.6 \%$ on a per unit of energy produced basis.

\subsection{Impact Assessment}

Life cycle impact assessment is an evolving technique used to characterize the possible consequences of a process. It links the results of the life cycle inventory with potential environmental and human health effects by defining relationships between activities resulting in emissions, energy use, and material consumption (stressors) with likely environmental effects (stressor categories). Examples of stressor categories are photochemical oxidants, climate change gases, and loadings that alter habitat. Two important aspects of this method of classification are that a single stressor is often associated with multiple impacts, and that not all stressors within a category result in equal amounts of damage to the environment.

The scope of impact assessment for this study involved classification of inventory data into stressor categories that are potentially linked to ecological and human health. It should be recognized that discovering and establishing a causal relationship between an emission identified in the inventory and an impact on the environment is not a component of this work or of life cycle assessment in general. The intent is not to prove or disprove that biomass power production via gasification is responsible for any degradation of the environment, but to index expected emissions, energy use, and material consumption with known consequences. This type of impact assessment is qualitative rather than quantitative, and uses the premise that less is better when examining the potential impacts of each stressor. More complete means of assessing the possible impacts of this process on the environment require fate modeling and concentration estimates. The major stressors identified in this LCA and the associated stressor categories are shown in Table 32. 
Table 32: Stressor Categories Associated with Biomass Power Production

\begin{tabular}{|c|c|c|}
\hline Stressor Category & Stressors & $\begin{array}{c}\text { Major Impact Category } \\
\text { H = Human health } \\
\mathbf{E}=\text { Ecological health } \\
\text { Area Impacted } \\
\text { L = Local (county) } \\
\mathbf{R}=\text { Regional (state) } \\
\text { G = Global }\end{array}$ \\
\hline Toxicants & $\begin{array}{l}\text { Pesticides, herbicides, fertilizers } \\
\text { Tars, diesel fuel, and other hydrocarbons } \\
\mathrm{SO}_{2}, \mathrm{SO}_{3}, \mathrm{H}_{2} \mathrm{~S}, \mathrm{NH}_{3} \\
\text { Fluorine and fluorides }\end{array}$ & $\begin{array}{c}\text { H, E; L } \\
\text { H, E; L } \\
\text { H, E; L, R, G } \\
\text { H, E; L, R }\end{array}$ \\
\hline $\begin{array}{l}\text { Photochemical oxidant precursors } \\
\text { and photochemical oxidants }\end{array}$ & $\begin{array}{c}\text { Hydrocarbons, non-methane hydrocarbons, } \\
\text { VOCs } \\
\text { Ozone }\left(\mathrm{O}_{3}\right)\end{array}$ & $\begin{array}{l}\mathrm{H}, \mathrm{E} ; \mathrm{L}, \mathrm{R} \\
\mathrm{H}, \mathrm{E}, \mathrm{L} \\
\mathrm{H}, \mathrm{E} ; \mathrm{L}, \mathrm{R}\end{array}$ \\
\hline Particulates & $\begin{array}{l}\text { Wood dust } \\
\text { Construction, cement, road dust } \\
\text { Microorganisms, spores, fungi }\end{array}$ & $\begin{array}{l}\text { H, E; L } \\
\text { H, E; L } \\
H, E ; L, R\end{array}$ \\
\hline Air pollutants & $\begin{array}{c}\mathrm{CO}, \mathrm{O}_{3}, \mathrm{NO}_{x}, \mathrm{SO}_{2}, \mathrm{SO}_{3}, \mathrm{H}_{2} \mathrm{~S} \\
\text { hydrocarbons, } \mathrm{NH}_{3} \\
\text { Chlorinated compounds } \\
\text { wood dust, sand dust }\end{array}$ & $\begin{array}{l}\mathrm{H}, \mathrm{E} ; \mathrm{L} \\
\mathrm{H} ; \mathrm{L} \\
\mathrm{H} ; \mathrm{L}\end{array}$ \\
\hline Solid waste & $\begin{array}{l}\text { Catalysts } \\
\text { Char } \\
\text { Gypsum } \\
\text { Sand }\end{array}$ & $\begin{array}{l}\text { H, E; L, R } \\
\mathrm{H}, \mathrm{E} ; \mathrm{L}, \mathrm{R} \\
\mathrm{H}, \mathrm{E} ; \mathrm{L}, \mathrm{R} \\
\mathrm{H}, \mathrm{E} ; \mathrm{L}, \mathrm{R}\end{array}$ \\
\hline Physical trauma & $\begin{array}{l}\text { Accidents } \\
\text { Noise } \\
\text { Odor }\end{array}$ & $\begin{array}{l}\mathrm{H} ; \mathrm{L} \\
\mathrm{H} ; \mathrm{L} \\
\mathrm{L}\end{array}$ \\
\hline Climate change & $\begin{array}{l}\mathrm{CO}_{2}, \mathrm{CH}_{4} \text {, nitrates, sulfates, } \\
\text { changes in plant growth }\end{array}$ & $\begin{array}{c}E ; G \\
E, L, G\end{array}$ \\
\hline Acidification precursors & $\mathrm{SO}_{2}\left(\mathrm{H}_{2} \mathrm{SO}_{4}\right), \mathrm{NO}_{2}\left(\mathrm{HNO}_{3}\right), \mathrm{CO}_{2}\left(\mathrm{HCO}_{3}-\right)$ & E; R, G \\
\hline Nutrients & Nitrates, sulfates & $\mathrm{H}, \mathrm{E} ; \mathrm{L}, \mathrm{R}$ \\
\hline Habitat effects & $\begin{array}{l}\text { Monoculture, non-native species, flora kill, } \\
\text { animal and insect kill }\end{array}$ & $E ; L, R$ \\
\hline Resource depletion & $\begin{array}{c}\text { Fossil fuel use } \\
\text { Water use } \\
\text { Mineral and ore use } \\
\text { Groundwater pollution } \\
\text { Topsoil erosion } \\
\end{array}$ & $\begin{array}{c}E ; R, G \\
E ; R \\
E ; R, G \\
E ; L, R \\
E ; L\end{array}$ \\
\hline
\end{tabular}




\subsection{Summary of Results and Discussion}

Given that electric power production from biomass has considerable potential to contribute to energy supplies in the United States, it's important to assess the environmental consequences up-front, while system components are still being defined. By analyzing the emissions, resource consumption, and energy use of the entire system, including biomass production, transportation, and electricity generation, the dominant sources of environmental impacts can be determined and the resulting effects can be reduced. For these reasons, a life cycle assessment of a biomass power plant, including all upstream production and downstream disposal processes, was conducted.

General trends can be seen when examining the resources, emissions, and energy over the life of the biomass-to-electricity system described in this report. In years preceding power plant construction and operation, all of the stressors are associated with feedstock production, and as expected, there is a yearly increase as the number of fields in production is increased. A majority of the stressors are highest in the two years before plant operation due to activities associated with plant construction. The impacts then tend to be level during plant operation even with the construction and decommissioning activities associated with the farm equipment and truck transportation. Finally, a gradual decrease is seen, starting in year 23 when biomass production tapers off, leading up to a rapid decrease in impacts during final decommissioning.

Of all air emissions from the system, $\mathrm{CO}_{2}$ is emitted in the greatest quantity. Feedstock production, primarily the use of fossil fuels in farming operations, is responsible for greater than half of all net $\mathrm{CO}_{2}$ emissions. Other emissions commonly described as greenhouse gases, specifically methane and nitrous oxide, are emitted in very small quantities and add a minimal amount to the global warming potential of this system.

Because carbon dioxide emitted from the power plant is recycled back to the biomass as it grows, biomass power systems have the ability to reduce the overall amount of $\mathrm{CO}_{2}$ added to the atmosphere. The system studied was found to have a 95\% carbon closure, with $100 \%$ representing total recycle, i.e., no net addition of $\mathrm{CO}_{2}$ to the atmosphere. The amount of carbon that is sequestered by the soil at the plantation most strongly affects the carbon closure of the system. If the range of literature values for soil carbon sequestration is applied, carbon closure may be as low as $83 \%$ or as high as $200 \%$ (i.e., a net reduction in the amount of atmospheric $\mathrm{CO}_{2}$ ). Conducting sensitivity analyses on other assumptions used in this study predicts carbon closures greater than $94 \%$.

The base case analysis assumed that there would be no net accumulation or loss in soil carbon, with a sensitivity analysis showing that if $1.9 \mathrm{Mg} / \mathrm{ha}$ over the seven year crop rotation could be sequestered, the carbon cycle could be closed. In other words the system would be a zero-net $\mathrm{CO}_{2}$ process. Literature values for soil carbon build-up ranged from a loss of 4.5 to a gain of 40.3 $\mathrm{Mg} / \mathrm{ha} /$ seven years. 
Isoprene, the compound used to model biogenic emissions from the trees, is released to the air in the second highest amount. However, its impact on the environment cannot be directly assessed from this result without further study. NOx and NMHCs are the next highest emitted, followed by SOx. NOx, SOx, and particulates are released from the power plant at rates one-fifth, one-tenth, and 1/28th of those required by the New Source Performance Standards (NSPS) for fossil-fueled plants. Particulate emissions, although not found to be released in significant quantities overall, are greater than six times higher during the two years of plant construction than during normal operation. NMHC emissions, primarily from operating the power plant, represent only $0.9 \%$ of all air emissions. The majority of air emissions produced in the feedstock production section are typical of those from diesel-fueled farm equipment. However, the total amount of these emissions is small in comparison to air emissions from the power plant.

A previous technical and economic analysis on this system was revisited in the context of this life cycle assessment. To reduce the emissions of VOCs from the power plant, a slipstream of the dryer exhaust gas is recycled to the char combustor. This configuration is a change from the original design and technoeconomic analysis given in Craig and Mann (1996). The cost of an additional blower and its electricity consumption result in a minimal increase in the selling price of electricity to $6.75 \phi / \mathrm{kWh}$ in current dollars or $5.25 \phi / \mathrm{kWh}$ in constant dollars.

Emissions to water occurred mostly in the feedstock production system since the power plant treats a significant quantity of its water prior to discharge. It's important to note, however, that the total amount of water pollutants was found to be small compared to other emissions. In addition to the air and water emissions, non-hazardous solid waste was produced, but in small quantities.

Water is the resource consumed in the largest quantity by this system. Because rainfall was assumed to be adequate for water requirements at the plantation, water is consumed only in upstream manufacturing operations, and especially by the power plant itself. Excluding water, oil, iron, and coal account for $95 \%$ by weight of the other resources consumed. As expected, the majority of fossil fuels are consumed by farming operations in feedstock production. By weight of substance, the percentage of the total consumption of natural gas, oil, and coal used in the feedstock subsystem equals $95 \%, 79 \%$, and $67 \%$, respectively. Because of equipment construction, the power plant was found to require more electricity, and thus more coal and natural gas, than biomass transportation. However, the amount of oil consumed by transportation is higher than by the power plant subsystem.

In addition to quantifying emissions, a key aspect of this work was to evaluate the energy flows within the system boundaries to assess the net energy produced. The net energy production of the system was found to be highly positive. One unit of fossil fuel energy is required to produce 15.6 units of biomass-generated electricity. The worst case tested in the sensitivity analyses gave a ratio of no less than 11. Additionally, the life cycle efficiency (34.9\%), which includes all energy consumed within the system, is not substantially less than the power plant efficiency (37.2\%). Not including power plant parasitic losses, feedstock production accounts for $77 \%$ of the total system energy consumption. 
Transporting the biomass to the power plant required fewer resources and less energy than both feedstock production and power plant operations. Additionally, air and water emissions are lowest from this subsystem. Changing the mode and/or emissions of transportation will not greatly affect the overall impact of this system on the environment.

Apart from the impact soil carbon sequestration has on the carbon closure, biomass yield was found to have the largest effect on the amount of resource consumption, net emissions, and energy use for the system. Changing the amount of fossil fuel used at the plantation and changing the power plant efficiency also had noticeable effects. Most importantly, however, the conclusions drawn remain the same for all sensitivity cases studied. That is, carbon closure and life cycle efficiency are very high for this system. Additionally, the fossil fuel energy ratio does not decrease substantially, indicating that the electric energy the system produces will always be far more than the fossil fuel energy it consumes.

\subsection{Future Work}

To complement this work, we will extend the life cycle study of biomass processes and expand the developed methodology to other systems. The next set of studies will seek to answer the question of how this process measures up environmentally against fossil-based systems. Life cycle assessments will be performed on three coal-fired power plants, one which incorporates new emissions control technologies, one which meets the New Source Performance Standards, and one which represents a plant in operation today. Another power generation option that is likely to be examined is co-firing of biomass in coal- or oil-fired boilers. This option of retrofitting existing power plants will likely be the first step for utilizing biomass in commercial, large-scale electricity systems. Finally, an assessment of a natural gas-fired IGCC plant may be conducted.

A system similar to that studied in this analysis but which uses other biomass feedstocks may also be examined. An herbaceous feedstock such as switchgrass, a feed from which co-products can be generated, such as alfalfa, and agricultural and forest waste wood are examples.

An interesting extension of this study would be the incorporation of biomass-derived diesel fuels into farming operations. Theoretically, this would close the carbon balance further, although the emissions related to growing biomass would be increased. Additionally, it would be useful to study the environmental effects of biomass crops compared to traditional agriculture crops.

\subsection{Related Studies}

A brief summary of some of the previous studies that relate to this work is given in this section. Data from many of these studies were used in this assessment, and referenced elsewhere in the text. Although this list is not all-inclusive, it serves to illustrate the nature of past efforts. 
DynCorp EENSP, Inc. (1995).

Ellington and Meo, 1990-91, 1993

Graham et al (1992)

Gustavsson et al (1996)

OTA Background Paper (1993)

Perlack et al (1992)

Pimentel et al (1981)
A life cycle assessment of $\mathrm{CO}_{2}$ and methane emissions from different renewable and non-renewable technologies, including a slightly different version of the same biomass technology assessed here. Energy use and other stressors were not assessed. Emissions factors from a modified version of the TEMIS model was used. Different capacity addition scenarios were addressed.

A life cycle assessment showing the carbon dioxide emissions from using biomass from tree farms to produce methanol for reformulated gasoline. Presented a useful means of tracking the accumulated amount of $\mathrm{CO}_{2}$ in the atmosphere. Did not include power production as a use for the biomass.

Assessment of the $\mathrm{CO}_{2}$ released in producing biomass in a specific short rotation woody crop scenario. Contains a cursory glance at what the net $\mathrm{CO}_{2}$ would be for different uses of the biomass. Did not include all upstream processes and transportation. However, the $\mathrm{CO}_{2}$ released in producing biomass was found to be very close to that reported for the current study.

Assumed that the only $\mathrm{CO}_{2}$ inputs into the process were from energy use, and could thus be displaced with biomass-based products. Did not include the upstream processes that use fossil fuels as chemical inputs. $\mathrm{CO}_{2}$ was the only stressor studied.

Cursory discussion of the issues involved in establishing bioenergy in the U.S. Does not report an analysis.

Excellent source of information on the environmental consequences of producing biomass fuel. According to ORNL, however, some data are now outdated given experience gained in the last few years. Did not discuss upstream processes.

General approach taken to evaluate the energy balance of producing energy from crop and forest residues. Few environmental effects discussed. 
Ranney and Mann (1994)

Ranney et al (1991)

Schlamadinger and Marland, 1996

Turhollow and Perlack, 1991
Good summary of what has been learned about the environmental impacts of growing biomass. Issues discussed include previous land use, farm chemical requirements and fates, water quality, air emissions, sustainability, and biodiversity.

Assessment of the total carbon flows involved in producing biomass as a fuel. Very useful discussion on how above- and below-ground biomass will affect soil carbon. Some data are now considered to be outdated.

A life cycle assessment showing the carbon dioxide emissions from using conventional and short-rotation forestry to produce biofuels and long- and short-term wood products to displace fossil fuels. Showed cumulative benefits over periods of time ranging from zero to 100 years. Did not include upstream processes or power production as a use for the biomass.

An analysis of the $\mathrm{CO}_{2}$ emissions from biomass and fossil fuels. Based on conversion factors for each technology. Does not include upstream processes. Assumptions on farming inputs are now considered by ORNL to be outdated.

\subsection{Acknowledgments}

We would like to acknowledge the Department of Energy's Biomass Power Program for funding this work, and Dr. Richard Bain, Dr. Ralph Overend and Kevin Craig for extensive technical guidance and review. Also, our thanks to the many people outside of NREL who have contributed their time and effort in assisting us, specifically, Bruce Vigon of Battelle for providing ideas on how best to conduct this study, ORNL's Environmental Sciences Division for supplying an extensive amount of information on the logistics and environmental consequences of producing biomass as a dedicated energy crop, and Vince Camobreco of Ecobalance for his many hours of technical support for the TEAM and TEAM Plus software. 


\subsection{References and Pertinent Literature}

Anderson, R.O. (1993). Ms6001FA - An Advanced Technology 70 MW-Class 50/60 Hertz Gas Turbine. Available from General Electric Company, Schenectady, NY.

Bain, R. (1992). Material and Energy Balances for Methanol from Biomass Using Biomass Gasifiers. Golden, Colorado: National Renewable Energy Laboratory, January.

Battelle Columbus Laboratories. (1976). Energy Use Patterns in Metallurgical and Nonmetallic Mineral Processing (Phase 6 - Energy Data and Flowsheets, Low-Priority Commodities), PB261 150 , July.

Boustead, I.; Hancock, G.F. (1979). Handbook of Industrial Energy Analysis. New York: John Wiley \& Sons, pp. 120-146.

Bouwman, A. F. (1989). "The Role of Soils and Land Use in the Greenhouse Effect." Netherlands Journal of Agricultural Science. 37:pp. 13-19.

Brown, R.C. (1994). The Potential for Biomass Production and Conversion in Iowa. Final Report to the Iowa Energy Center. Iowa State University. Ames, IA.

Breault, R.; Morgan, D. (1992). Design and Economics of Electricity Production from an Indirectly Heated Biomass Gasifier. TR4533-049-92. Columbus, OH: Battelle Memorial Institute. Work performed by Tecogen Inc., Waltham, MA, October.

Cervinka, V. (1980). "Fuel and Energy Efficiency," in Pimentel, D. (ed.), Handbook of Energy Utilization in Agriculture, CRC Press, pp. 15-21.

Craig, K.R.; Mann, M.K. (1996). Cost and Performance Analysis of Biomass-Based Integrated Gasification Combined Cycle (BIGCC) Power Systems. National Renewable Energy Laboratory Report no. NREL/TP-430-21657. Golden, CO: NREL, October.

Delucchi, M.A. (1993). Emissions of Greenhouse Gases from the Use of Transportation Fuels and Electricity, Volume 2: Appendixes A-S, Center for Transportation Research, Argonne National Laboratory, Report no. ANL/ESD/TM-22. November.

DynCorp EENSP, Inc. (1995). Assessment of the Environmental Benefits of Renewables Deployment: A Total Fuel Cycle Analysis of the Greenhouse Gas Impacts of Renewable Generation Technologies in Regional Utility Systems. Prepared for the National Renewable Energy Laboratory, contract no. DE-AC02-83CH10093. Golden, CO: National Renewable Energy Laboratory, May.

Ebasco Environmental. (1993). Wood Fuel Cofiring at TVA Power Plants. Contract 3407-1. 
Sacramento, CA: Ebasco Services Inc., October. Available from the Electric Power Research Institute, Contract 3407-1. Palo Alto, CA.

Ellington, R.T.; Meo, M. (1990-1991). "Calculating the Net Greenhouse Warming Effect of Renewable Energy Resources: Methanol from Biomass," J. Environmental Systems 20(4):287-301.

Ellington, R.T.; Meo, M.; El-Sayad, A. (1993). "The Net Greenhouse Warming Forcing of Methanol Produced from Biomass," Biomass and Bioenergy 4(6):405-418.

Environmental Catalyst Consultants, Inc. (1992). Status of Selective Catalytic Reduction for $\mathrm{NO}_{\mathrm{x}}$ Control in Electric Power Generation Applications.

Feldmann, J.; Paisley, M.A. (1988). Conversion of Forest Residues to a Methane-Rich Gas in a High-Throughput Gasifier. Columbus, Ohio: Battelle Columbus Laboratory, May.

Fluck, R.C., ed. (1992). "Energy Analysis in Agricultural Systems," in Energy in Farm Production, Elsevier, pp. 45-52.

Gas Turbine World 1992-93 Handbook. (1993). Fairfield, CT: Pequot Publishing Inc.

Gebhard, S.C.; Dingneng, W.; Overend, R.P.; Paisley, M.A. (1994). "Catalytic Conditioning of Synthesis Gas Produced by Biomass Gasification," Biomass and Bioenergy 7(1-6):307-313.

Golam, S.; Ehtonen, P.; Järveläinen, M. (1993). Wood Ash Analysis, Disposal and Utilization Possibilities. Report No. 19, Helsinki University of Technology, Espoo, Finland.

Graham, R.L.; Wright, L.L.; Turhollow, A.F. (1992). "The Potential for Short-Rotation Woody Crops to Reduce U.S. $\mathrm{CO}_{2}$ Emissions," Climate Change 22:223-238.

Grigal, D.F.; Berguson, W.E. (forthcoming). To be published in Biomass and Bioenergy.

Gustavsson, L.; Börjesson, P; Johansson, B; Svenningsson, P. (1996). "Reducing $\mathrm{CO}_{2}$ Emissions by Substituting Biomass for Fossil Fuels," Energy 37:6-8, pp. 1211-1216 (6).

Hansen, E. A. (1993). "Soil Carbon Sequestration beneath Hybrid Poplar Plantations in the North Central United States," Biomass and Bioenergy 5(6):431-436.

Houston, A. (1996). "Environmental Impacts of Conversion of Cropland to Short Rotation Woody Crops." Progress Report on the Ames Plantation to the University of Tennessee, Agricultural Experiment Station, September.

Hunt, R.G.; Sellers, J.D.; Franklin, W.E. (1992). "Resource and Environmental Profile Analysis: 
A Life Cycle Environmental Assessment for Products and Procedures," New York: Elsevier, Environ. Impact Assess Rev. 1992: Vol. 12, pp. 245-269.

Irving, J. (1997). Personal correspondence. Plant Manager at the McNeil Power Station, Burlington, VT.

Jirjis, Raida. (1997). "Health Risks Associated with the Storage of Wood Fuels." Proceedings of the IEA Bioenergy Task XI, Feedstock Preparation and Quality Workshop. ELSAMPROJEKT A/S. ISBN 87-986376-0-6. pp. 9-17.

Kropelin, B. (1997). Personal Correspondence. McNeil Power Station. Burlington, VT.

Marland, G.; Marland, S. (1992). "Should We Store Carbon in Trees?" Water, Air, and Soil Pollution 64:181-195.

Meridian Corporation. (1989). Energy System Emissions and Material Requirements, for the U.S. Department of Energy, Deputy Assistant Secretary for Renewable Energy, Washington, D.C., February.

Morbark, Inc. (1993). Morbark Report. Volume 1, Number 4. Winn, MI.

Motor Vehicle Manufacturers Association of the United States, Inc. (1995). "MVMA Motor Vehicle Facts and Figures '95. Motor Vehicle Manufacturers Association of the United States, Inc., Detroit, MI.

Oak Ridge National Laboratory. (1996). Personal Correspondence with Researchers in the Feedstock Development Program of the Environmental Sciences Division.

Office of the Federal Register National Archives and Records Administration. (1996). Code of Federal Regulations. Protection of Environment. Title 40. Part 60, July.

Ottinger, R.L.; Wooley, D.R.; Robinson, N.A.; Hodas, D.R.; Babb, S.E. (1991). Environmental Costs of Electricity. Pace University Center for Environmental Legal Studies. New York: Oceana Publications, Inc.

Overend, R.P. (1981). "The Average Haul Distance and Transportation Work Factors for Biomass Delivered to a Central Plant," in Biomass, Applied Science Publishers Ltd., England.

Perlack, R.D.; Ranney, J.W.; Wright, L.L. (1992). Environmental Emissions and Socioeconomic Considerations in the Production, Storage, and Transportation of Biomass Energy Feedstocks. Oak Ridge National Laboratory. ORNL/TM-12030, July.

Pimentel, D., ed. (1980). Handbook of Energy Utilization in Agriculture. Boca Raton, FL: CRC 
Press, p. 55.

Ranney, J.W.; Mann, L.K. (1994). "Environmental Considerations in Energy Crop Production," Biomass and Bioenergy 6(3):211-228.

Ranney, J.W.; Wright, L.L.; Mitchell, C.P. (1991). "Carbon Storage and Recycling in ShortRotation Energy Crops," in Mitchell, C.P. (ed.), Bioenergy and the Greenhouse Effect. NUTUK B 1991:1. Stockholm, Sweden, pp. 39-60.

Reicosky, D.C.; Kemper, W.D.; Langdale, G.W.; Kouglas Jr, C.L.; Rasmussen, P.E. (1995). "Soil Organic Matter Changes Resulting from Tillage and Biomass Production," Journal of Soil and Water Conservation (50):253-261.

Schlamadinger, B.; Marland, G. (1996). "Full Fuel Cycle Carbon Balances of Bioenergy and Forestry Options," Energy Conversion Management 37(6-8):813-818.

Schultz, S.C.; Kitto, J.B. (1992) STEAM Its Generation and Use, Babcock \& Wilcox, Barberton, $\mathrm{OH}$.

Sears, M.J. (1996). "Analysis of Surface Water Quality Impacts of Biomass Plantation Establishment in the Midwest." Thesis for Master of Science in Agricultural and Biological Engineering. Purdue University.

SETAC Foundation. (1991). A Technical Framework for Life-Cycle Assessment. Society of Environmental Toxicology and Chemistry and SETAC Foundation for Environmental Education, Inc., Washington, D.C.

Shultz, S.; Energy, Y. (1992). 'Combustion of 'Clean' and 'Contaminated' Wood in Fluidized Bed Boilers," Fifth Annual National Biofuels Conference and Exhibition, Boston, MA, October 19-20.

Thornton, F.C.; Joslin, J.D.; Bock, B. R.; Houston, A.; Green, T.H.; Schoenholtz, S.; Pettry, D.; Tyler, D.D. (1997). "Environmental Effects of Growing Woody Crops on Agricultural Land: First Year Effects on Erosion and Water Quality," in Proceedings of the 2nd Symposium on the Effects of Bioenergy Crops. International Energy Agency. Biomass and Bioenergy June 27-July 1, 1996 (in review).

Tillman, D.A.; Prinzing, D.E. (1994). "Fundamental Biofuel Characteristics Impacting CoalBiomass Cofiring," in Proceedings: Effects of Coal Quality on Power Plants-Fourth International Conference, Charleston, SC, August 17-19.

Tolbert, V.A. (1996-1997). Personal Correspondence. Oak Ridge National Laboratory. Oak Ridge, TN. 
Tolbert, V.A.; Thornton, F.C.; Joslin, J.D.; Bock, B.R.; Houston, A.; Tyler, D.; Green, T.H.; Schoenholtz, S.H.; Pettry, D.; Trettin, C.C. (1997). "Environmental Effects of Growing ShortRotation Woody Crops on Former Agricultural Lands," in Overend, R.P. and Chornet, E. (eds.), Making a Business from Biomass in Energy, Environment, Chemicals, Fibers, and Materials. Proceedings of the 3rd Biomass Conference of the Americas. pp. 297-301. Elsevier Science, LTD. New York.

Turhollow, A.F.; Perlack, R.D. (1991). "Emissions of $\mathrm{CO}_{2}$ from Energy Crop Production," Biomass and Bioenergy 1(3):129-135.

Tuskan, G. (1996). Personal Correspondence. Oak Ridge National Laboratory. Oak Ridge, TN.

SRI International. (1995). PEP Yearbook International. Menlo Park, California.

Ullman's Encyclopedia of Industrial Chemistry. Vol. A3, pp. 170-188.

United Nations, Framework Convention on Climate Change. (1996). Geneva, Switzerland.

U.S. Department of Energy, Assistant Secretary for Environmental Protection, Safety, and Emergency Preparedness. (1983). Energy Technology Characterizations Handbook, Environmental Pollution and Control Factors. Third edition, DOE/EP-0093, Washington, D.C.

U.S. Department of Energy. (1994). Annual Energy Review 1993. Energy Information Administration, Office of Energy markets and End Use. p. 249.

U.S. EPA. (1985). Compilation of Air Pollutant Emission Factors, Fourth edition. United States Environmental Protection Agency. AP-42. Vol. II: Mobile Sources. Ann Arbor, MI. pp. II-6.1-3.

U.S. EPA. (1995). Compilation of Air Pollutant Emission Factors. United States Environmental Protection Agency. AP-42. Vol. 1, parts 1,2, and 3; Stationary Point and Area Sources. Ann Arbor, MI.

Walsh, M.E.; Becker, D.A. (1996). Biocost Documentation. Oak Ridge National Laboratory. Oak Ridge, TN, October.

Weyerhaeuser, Stone \& Webster, Amoco, and Carolina Power \& Light. (1995). New Bern Biomass to Energy Project Phase 1 Feasibility Study. Response to NREL Contract No. LOI No. RCA-313326, June.

Wiltsee, G.A. (1993). Strategic Analysis of Biomass and Waste Fuels for Electric Power Generation. EPRI TR-102773. Sevenson Ranch, CA: Appel Consultants, Inc., November. Available from Electric Power Research Institute, Palo Alto, CA. 


\section{Feedstock Production Literature not Cited in Text}

Bhat, M. G.; English, B. C.; Turhollow, A. F., and Nyangito, H. O. (January, 1994). Energy in Synthetic Fertilizers and Pesticides: Revisited. ORNL; ORNL/Sub/90-99732/2.

Blankenhorn, P. R.; Bowersox, T. W., and Weyers, R. E. (1982). "Energy Relationships for Selected Cultural Investments." Forest Sci. 28:(3); pp. 459-469.

Davis, C. H. and Blouin, G. M. (1977). "Energy Consumption in the U.S. Chemical Fertilizer System from the Ground to the Ground". In Agriculture and Energy. Lockeretz, W., Ed. Academic Press. pp. 315-331.

Fluck, Richard C. (1992). "Energy Analysis for Agricultural Systems". In Energy in Farm Production. Fluck, Richard C., Ed. Elsevier. pp. 45-52.

International Fertilizer Development Center and United Nations Industrial Development Organization. "Pollution Control and Other Environmental Factors". In Fertilizer Manual. pp. 319-328.

Lockeretz, W. (1980). "Energy Inputs for Nitrogen, Phosphorus, and Potash Fertilizers". In Handbook of Energy Utilization in Agriculture. Pimentel, D., Ed. Boca Raton, FL. CRC Press. pp. 23-24.

Mudahar, M. S. and Hignett, T. P. (1987). "Energy Efficiency, Economics, and Policy in the Fertilizer Sector". In Energy in Plant Nutrition and Pest Control. Helsel, Z. R., Ed. Amsterdam. Elsevier. pp. 138-162.

Mudahar, M. S. and Hignett, T. P. (1987). "Energy Requirements, Technology, and Resources in the Fertilizer Sector". In Energy in Plant Nutrition and Pest Control. Helsel, Z. R., Ed. Amsterdam. Elsevier. pp. 25-61.

Mudahar, M. S. and Hignett, T. P. (1987). "Fertilizer and Energy Use". In Energy in Plant Nutrition and Pest Control. Helsel, Z. R., Ed. Amsterdam. Elsevier. pp. 1-6.

Stout, B. A. (1979). Energy for World Agriculture. Rome. Food and Agriculture Organization of the United Nations. p. 52. 
Appendix A: Graphical Representation of the LCA System in TEAM 


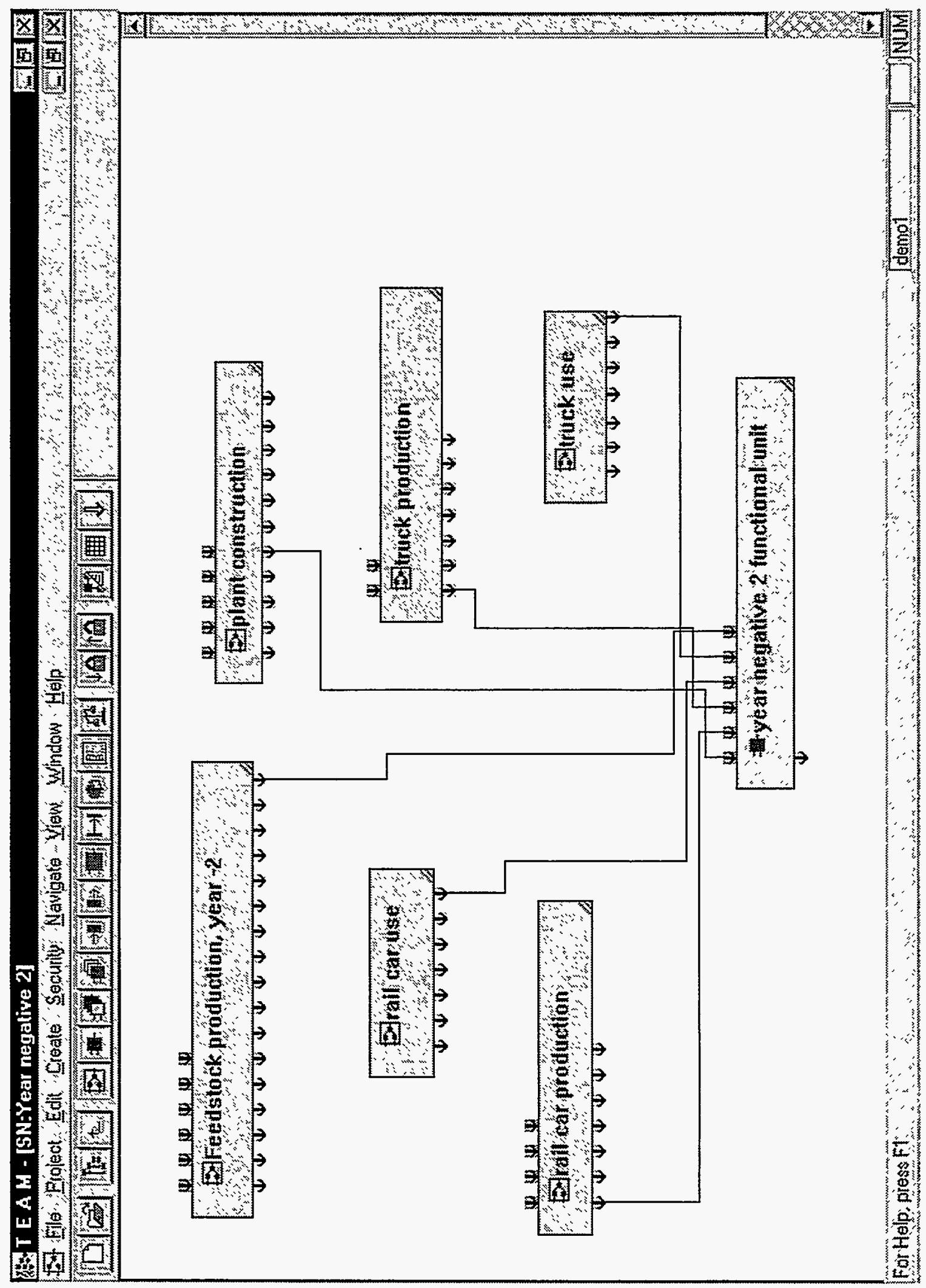




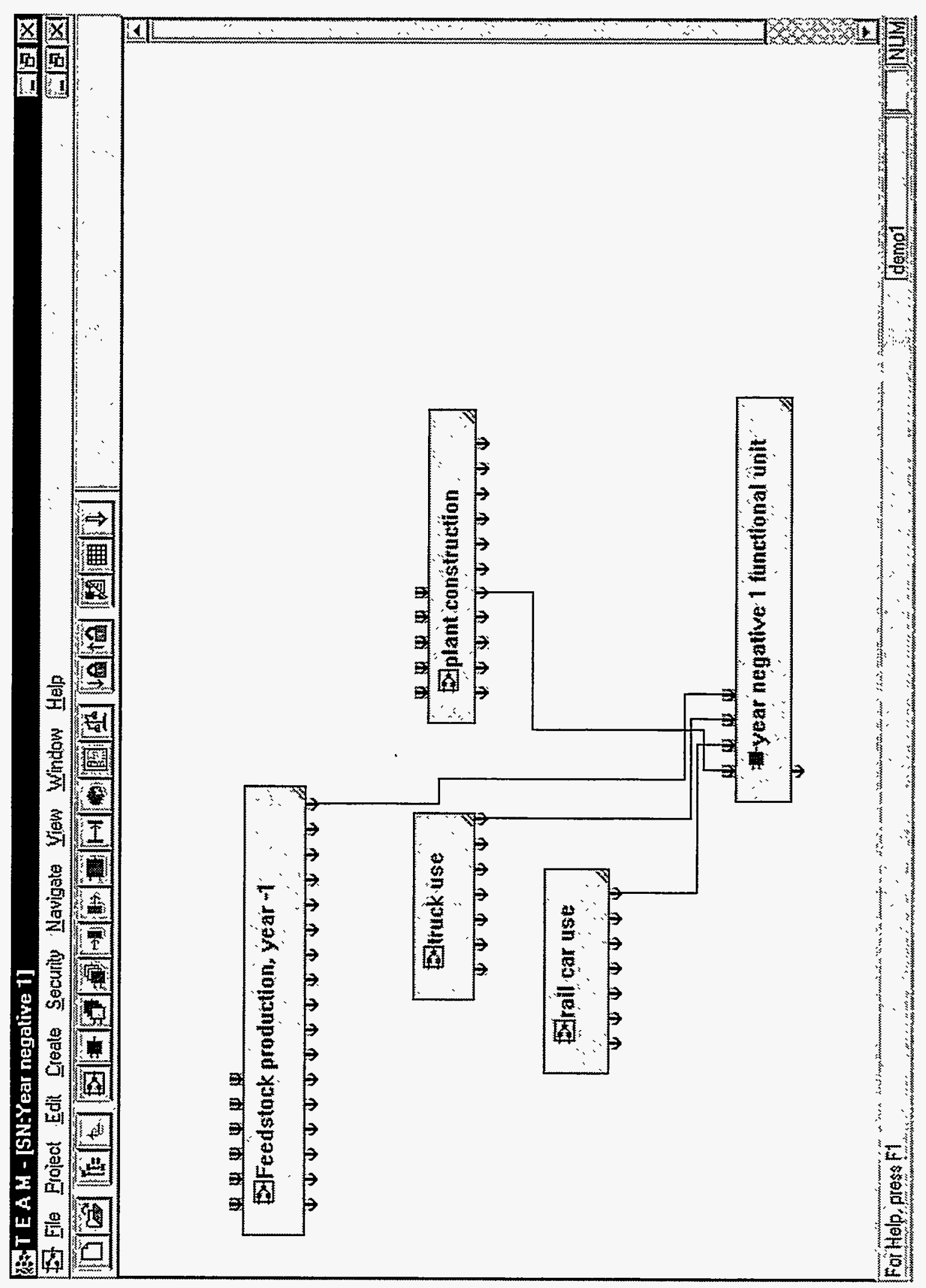




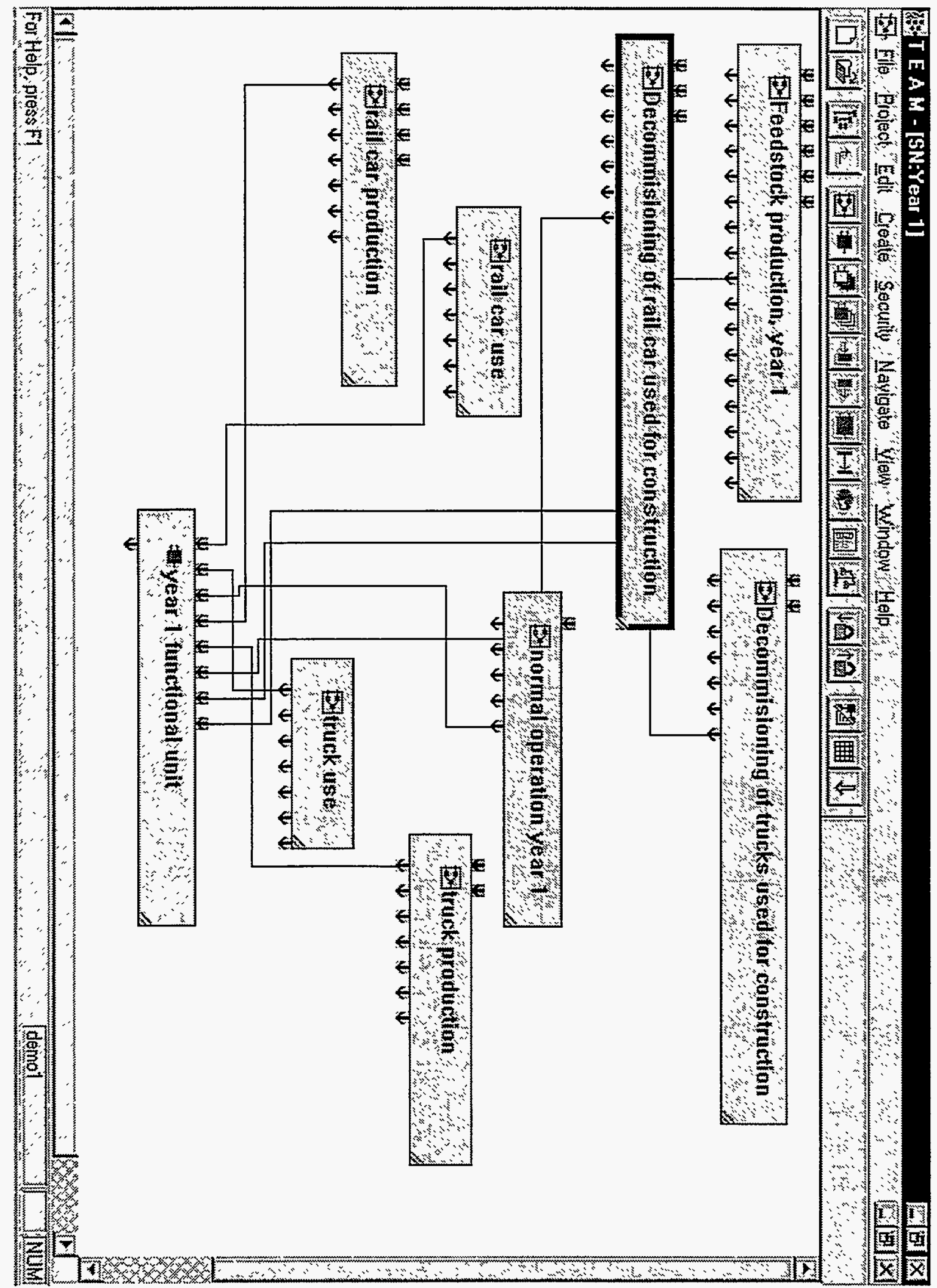




\section{[is T EAM - [SN:Year 3]}

File Project Edit Greale Security Navigate Yiew Window Help

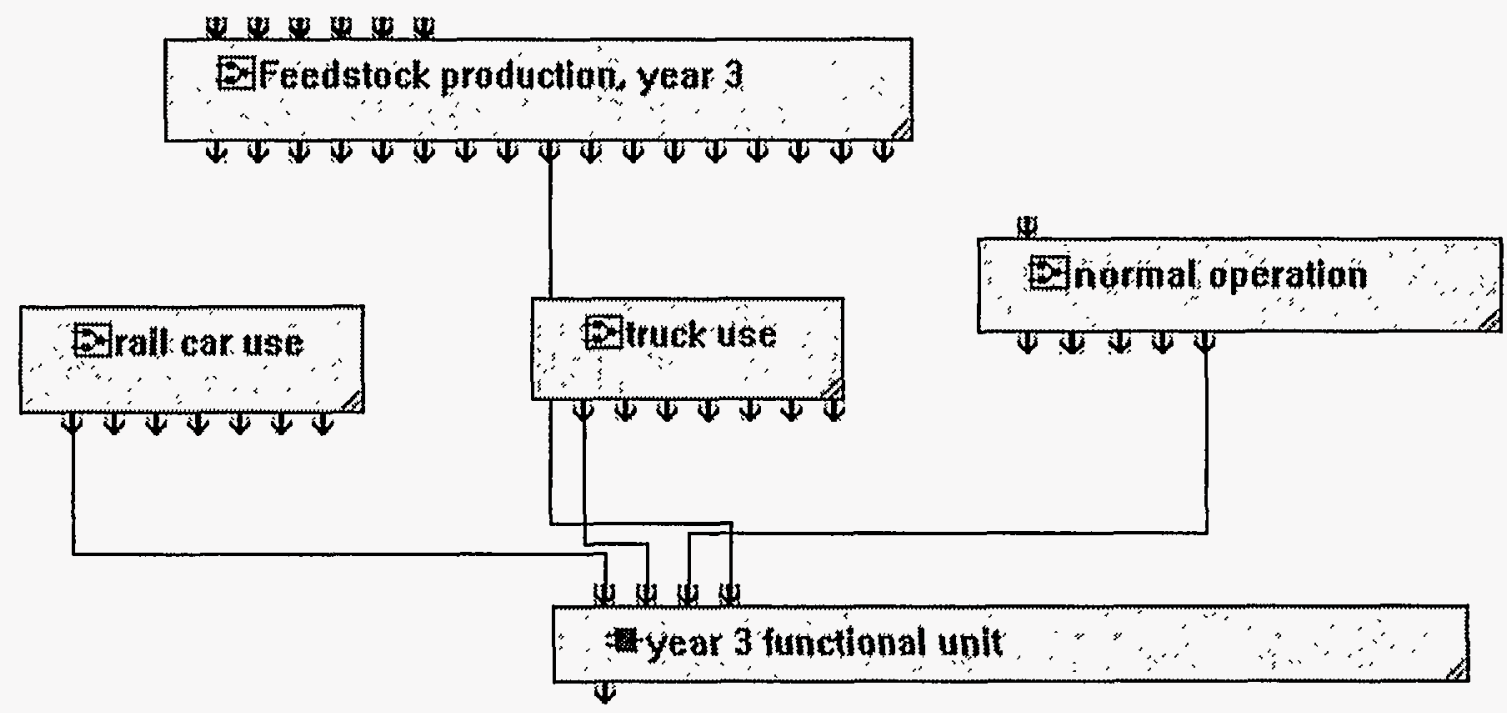

For Holp, prost 


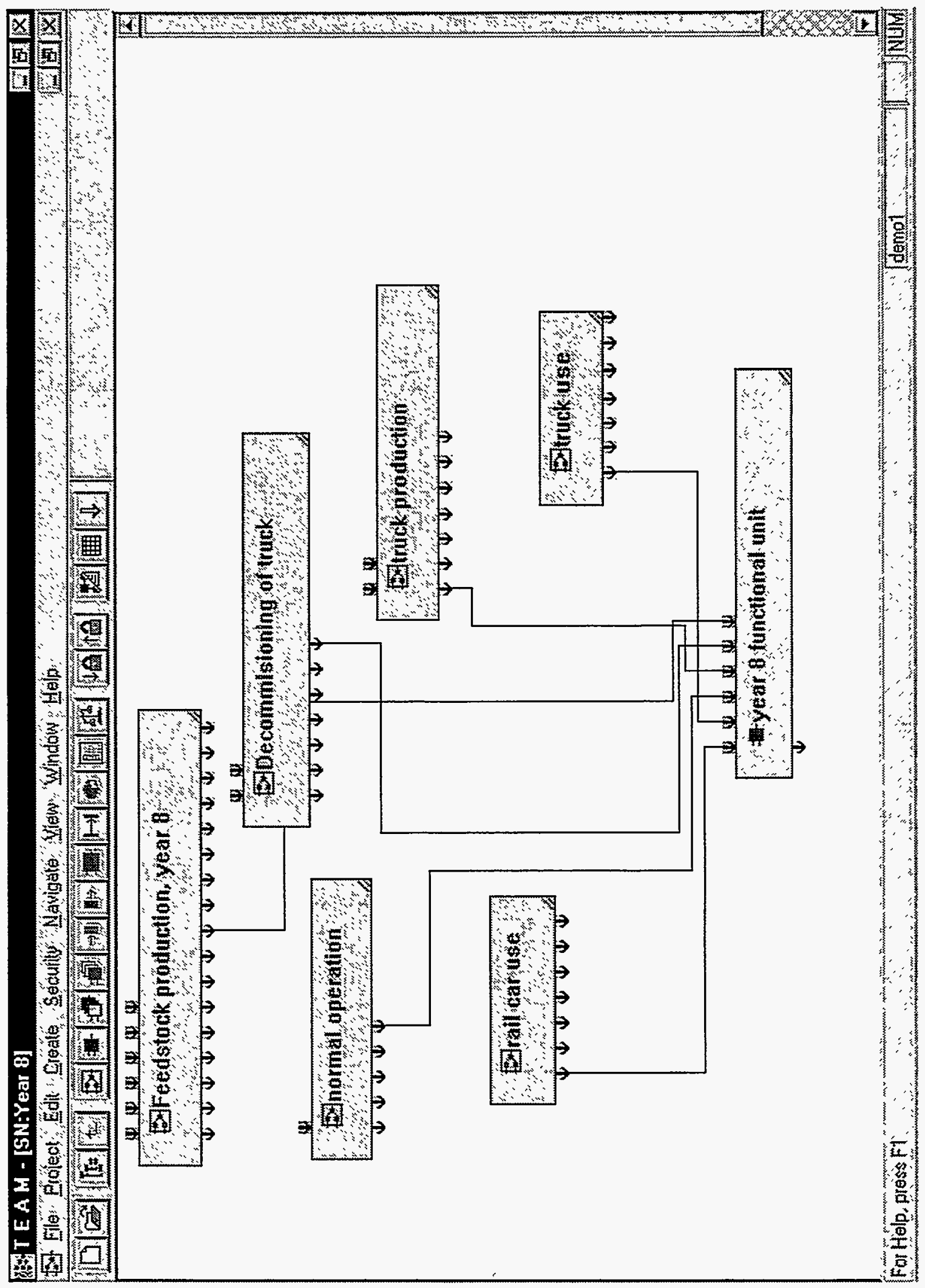




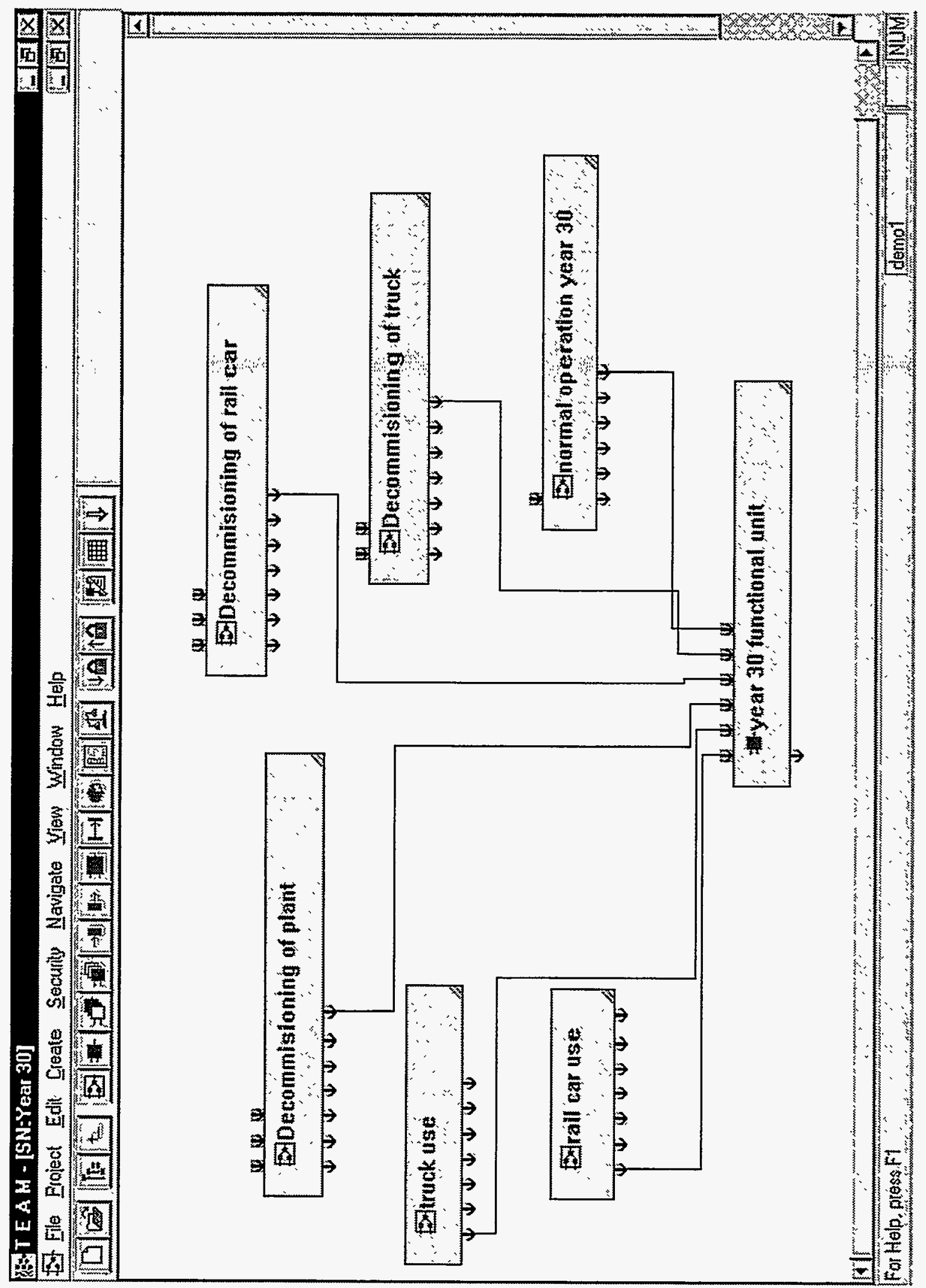




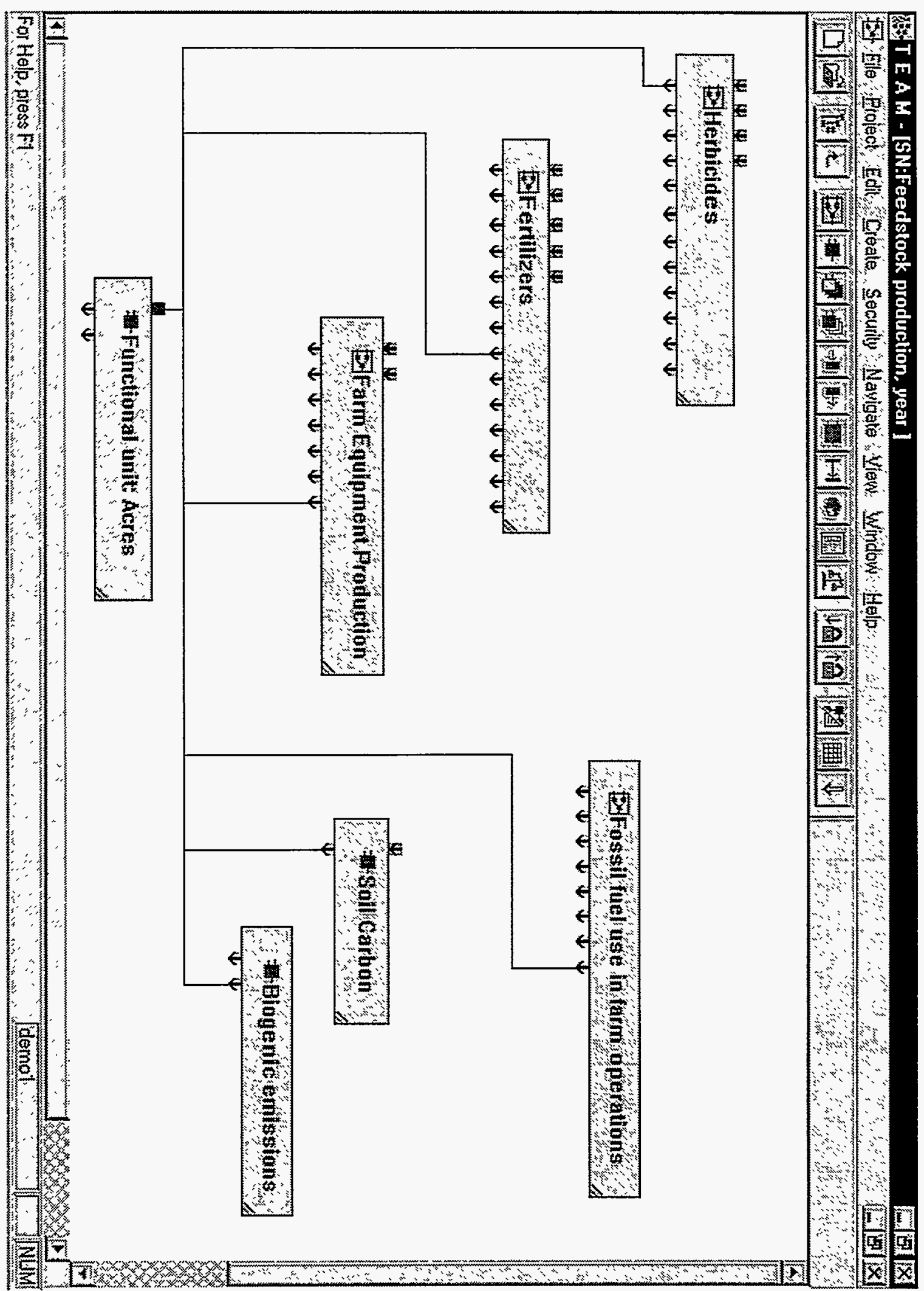




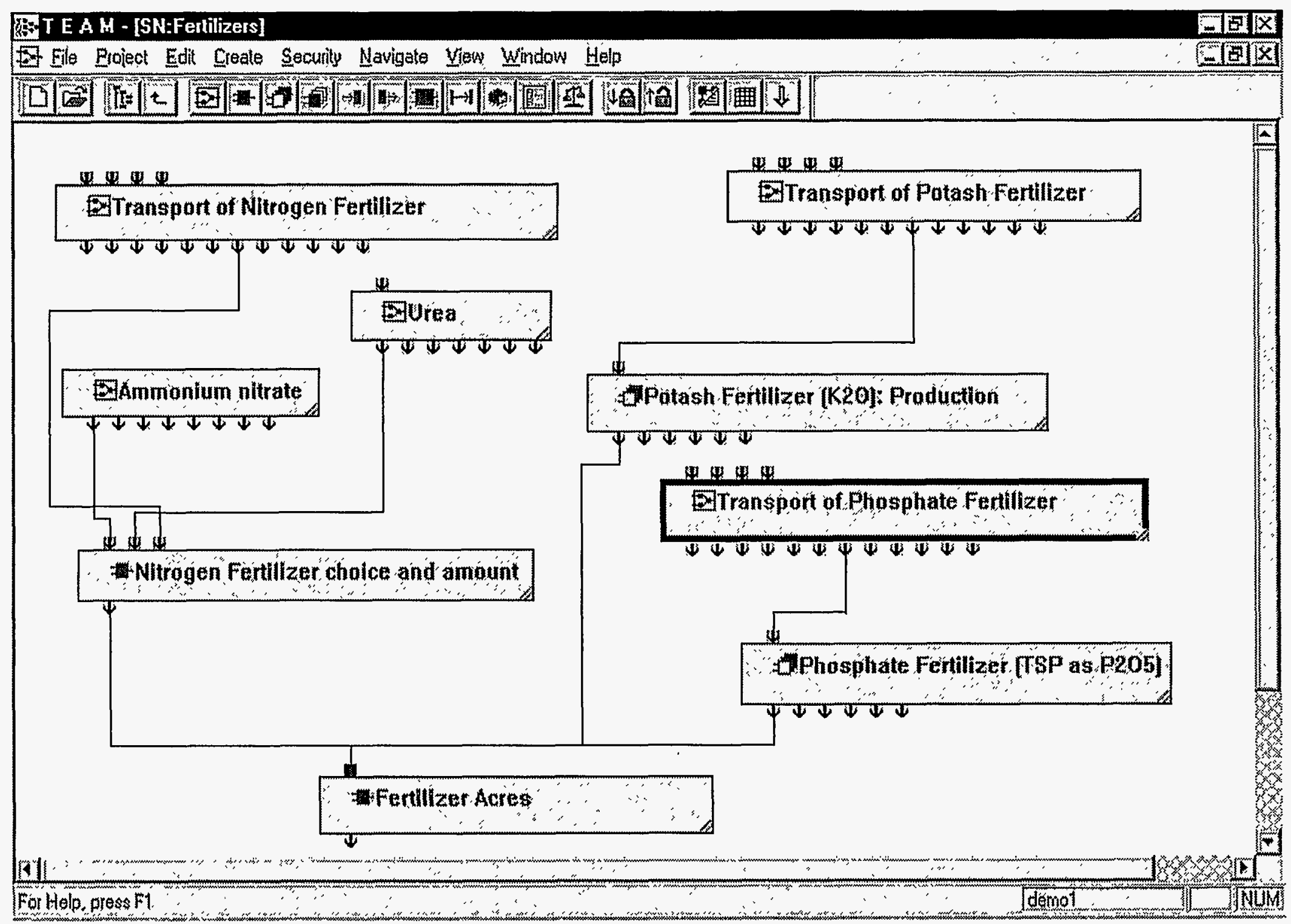




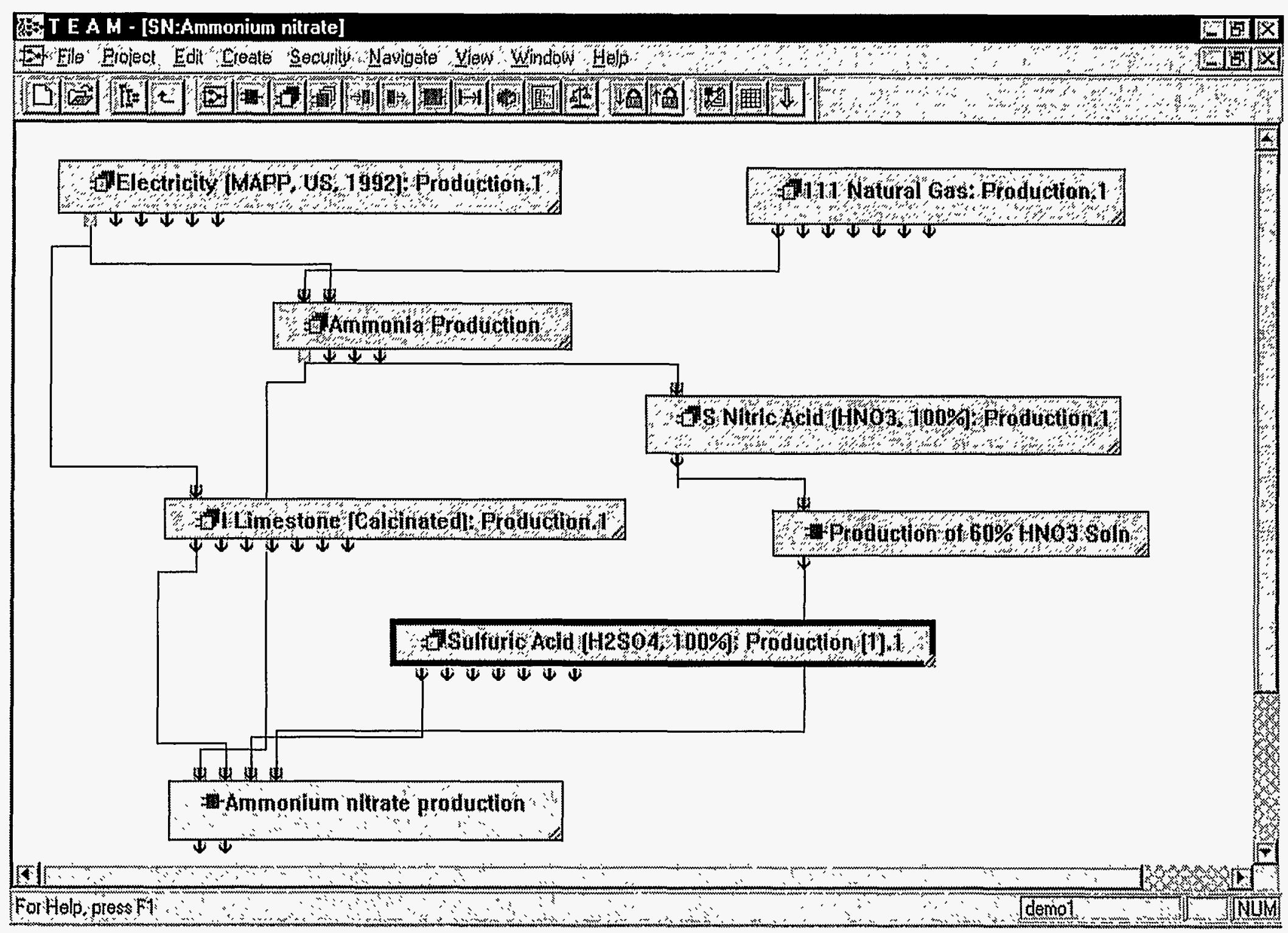




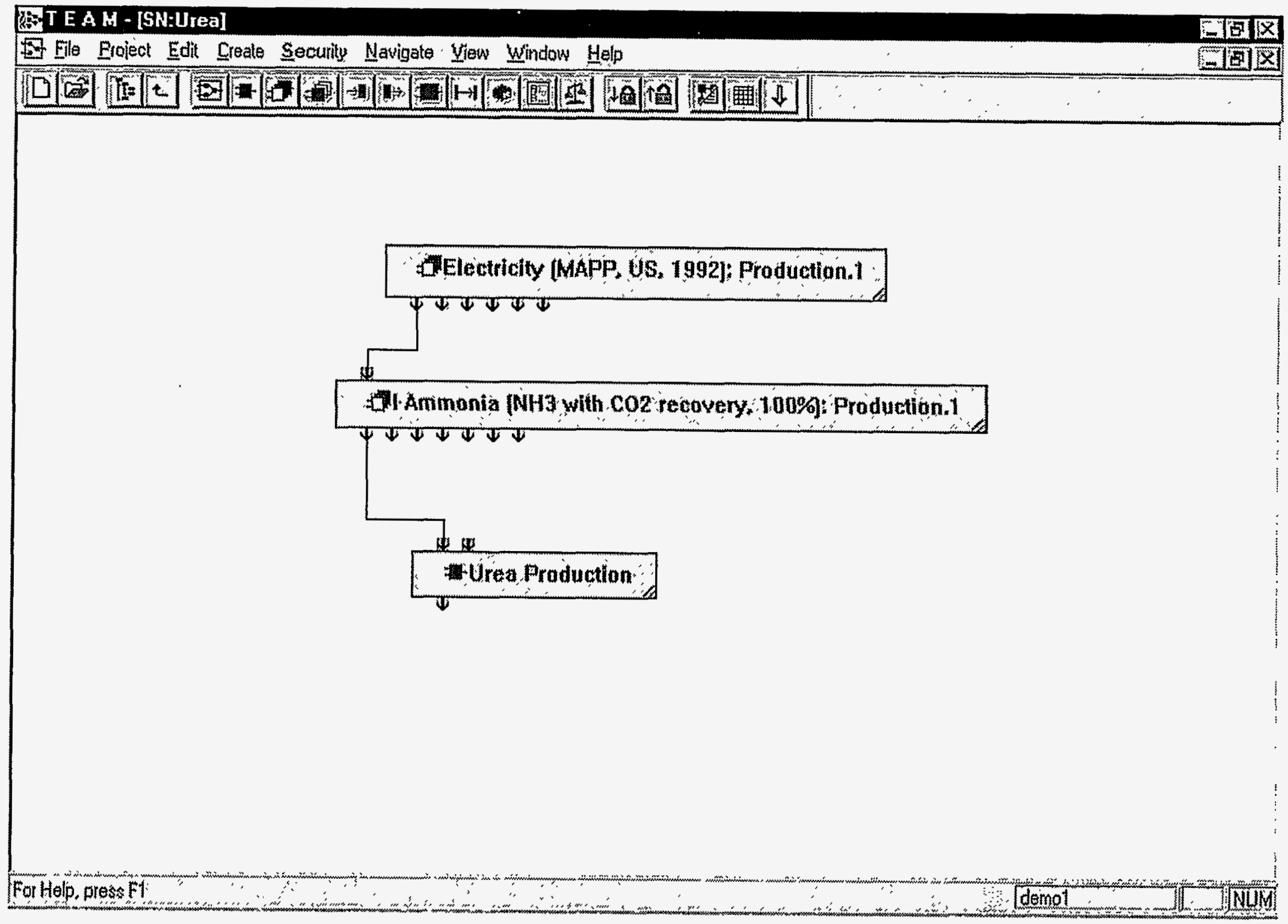




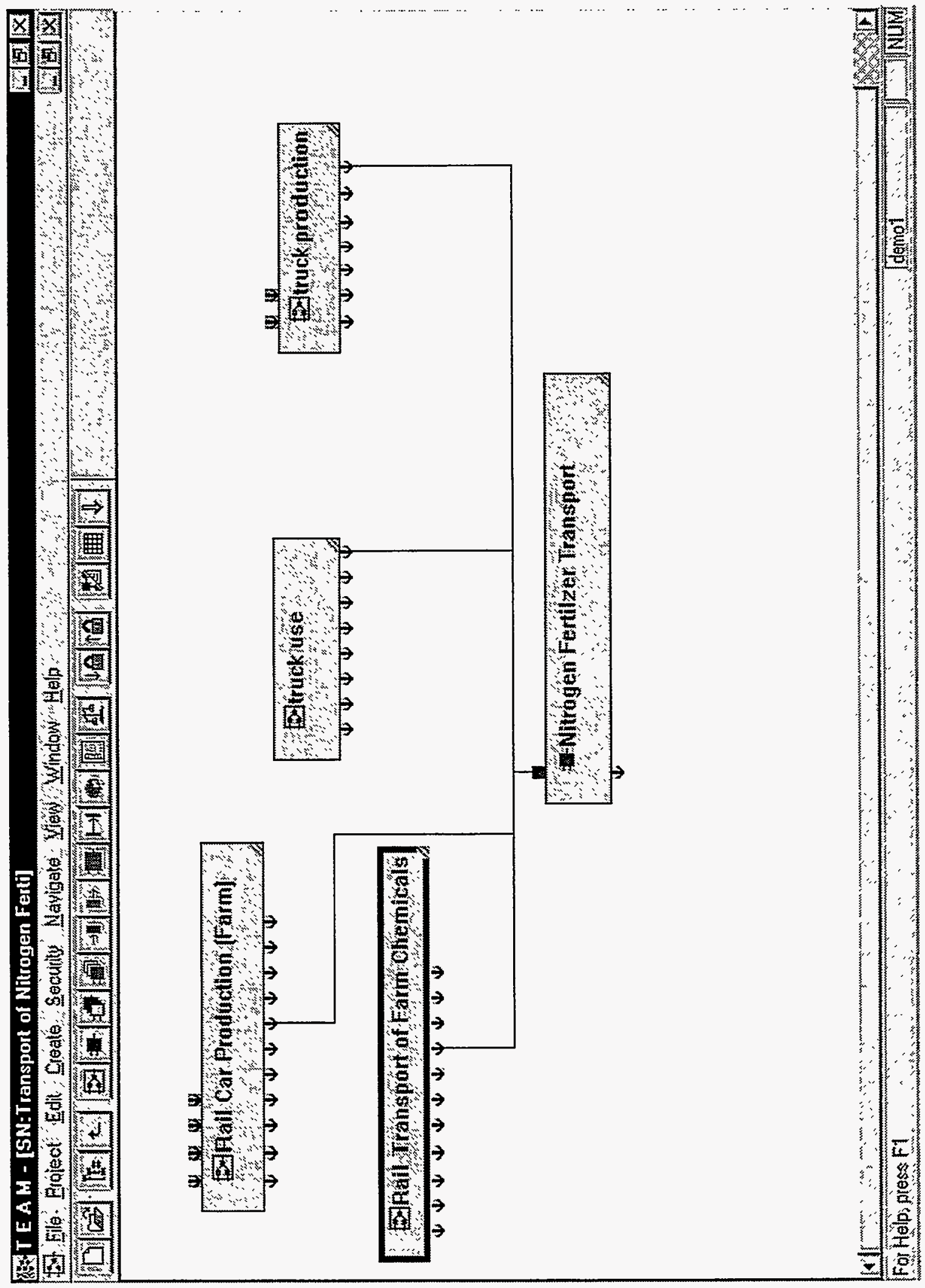




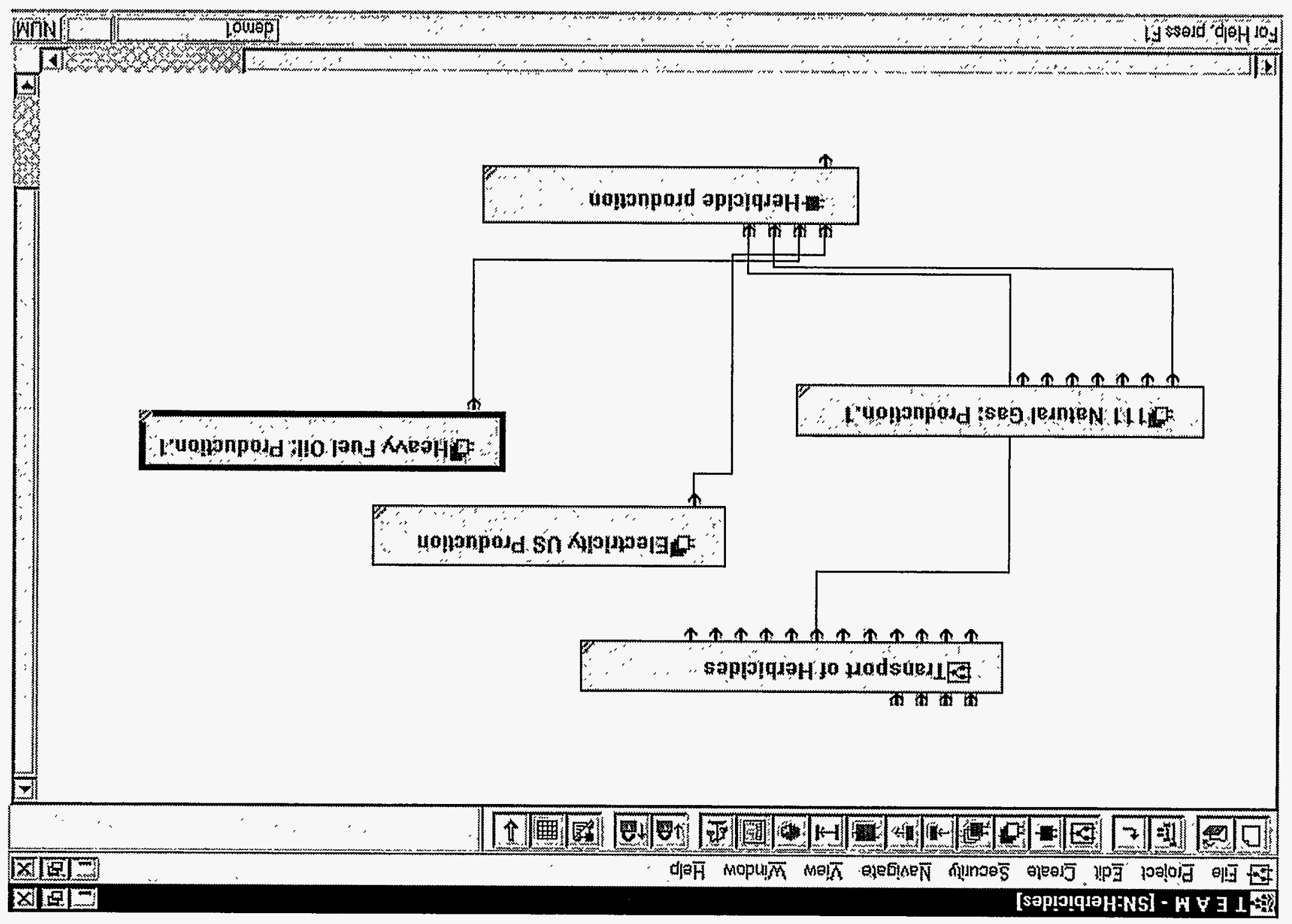




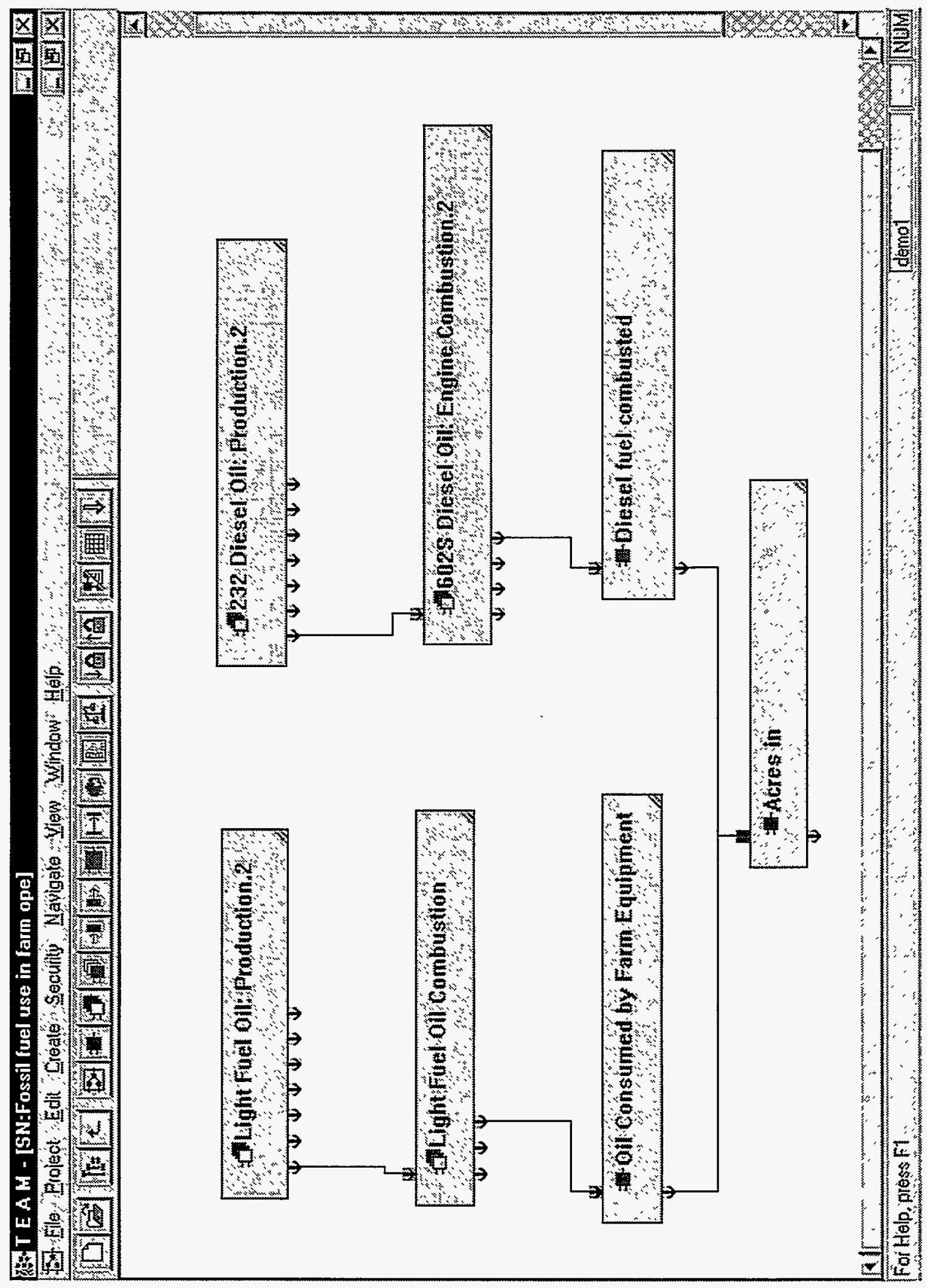




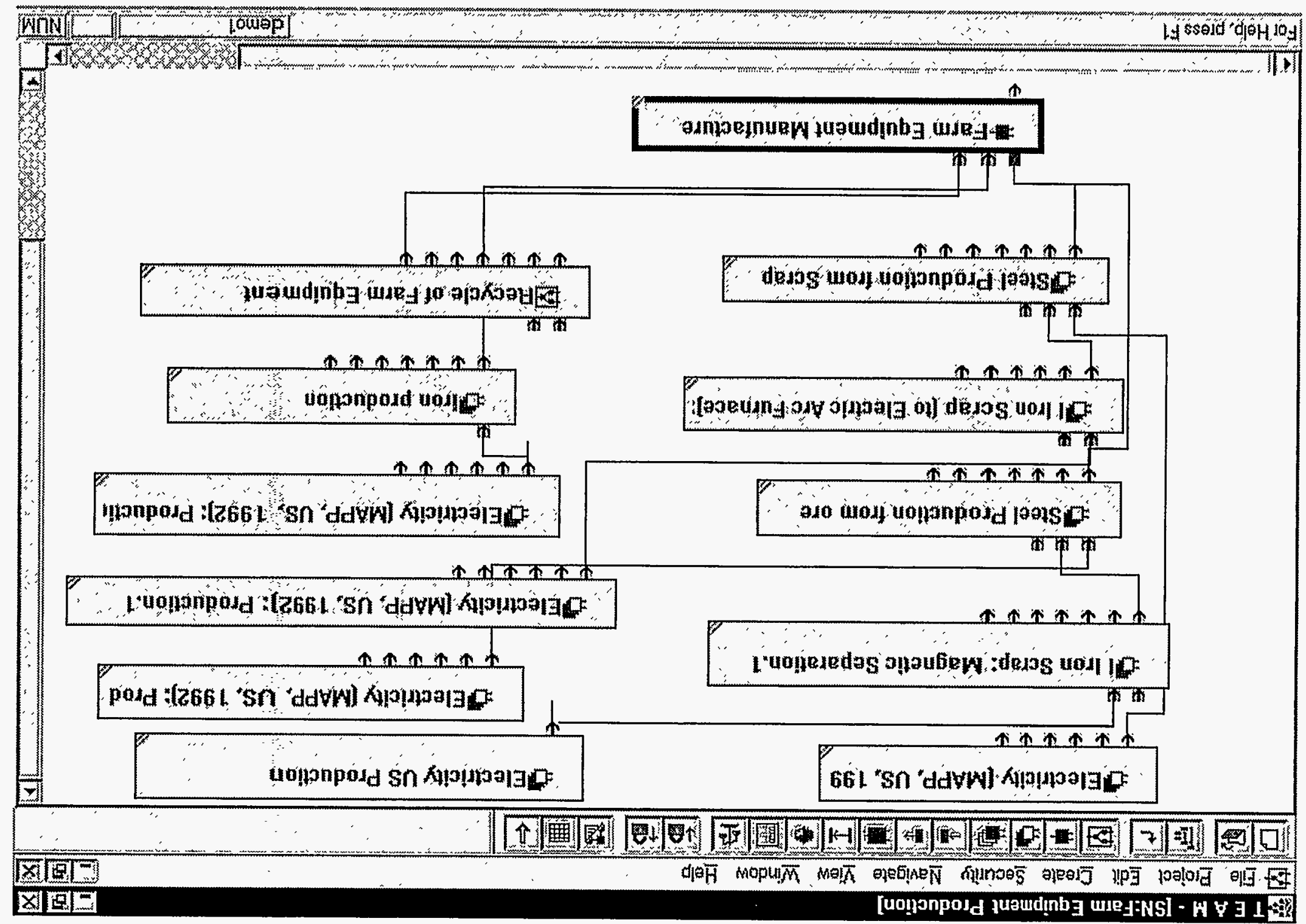




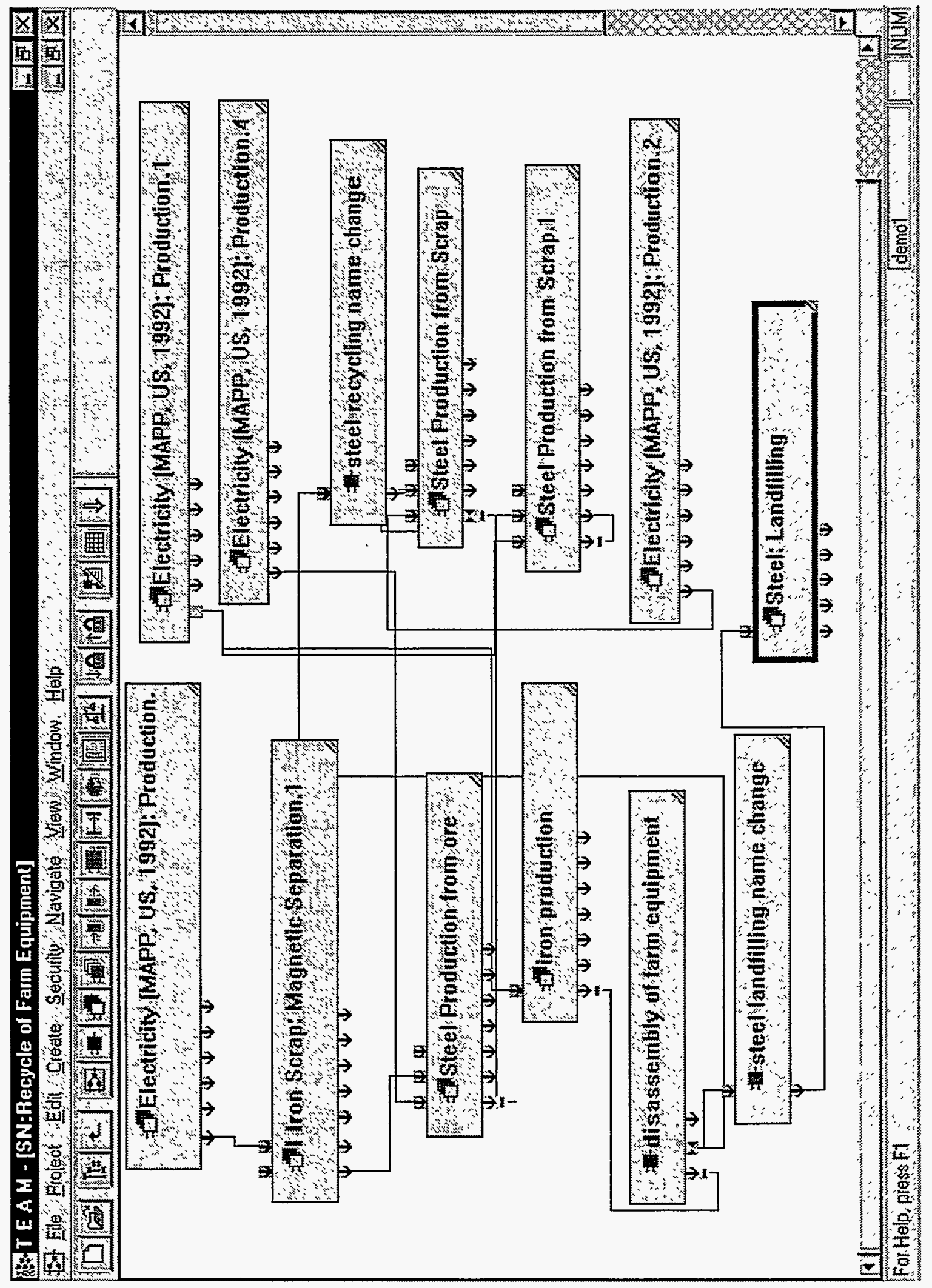




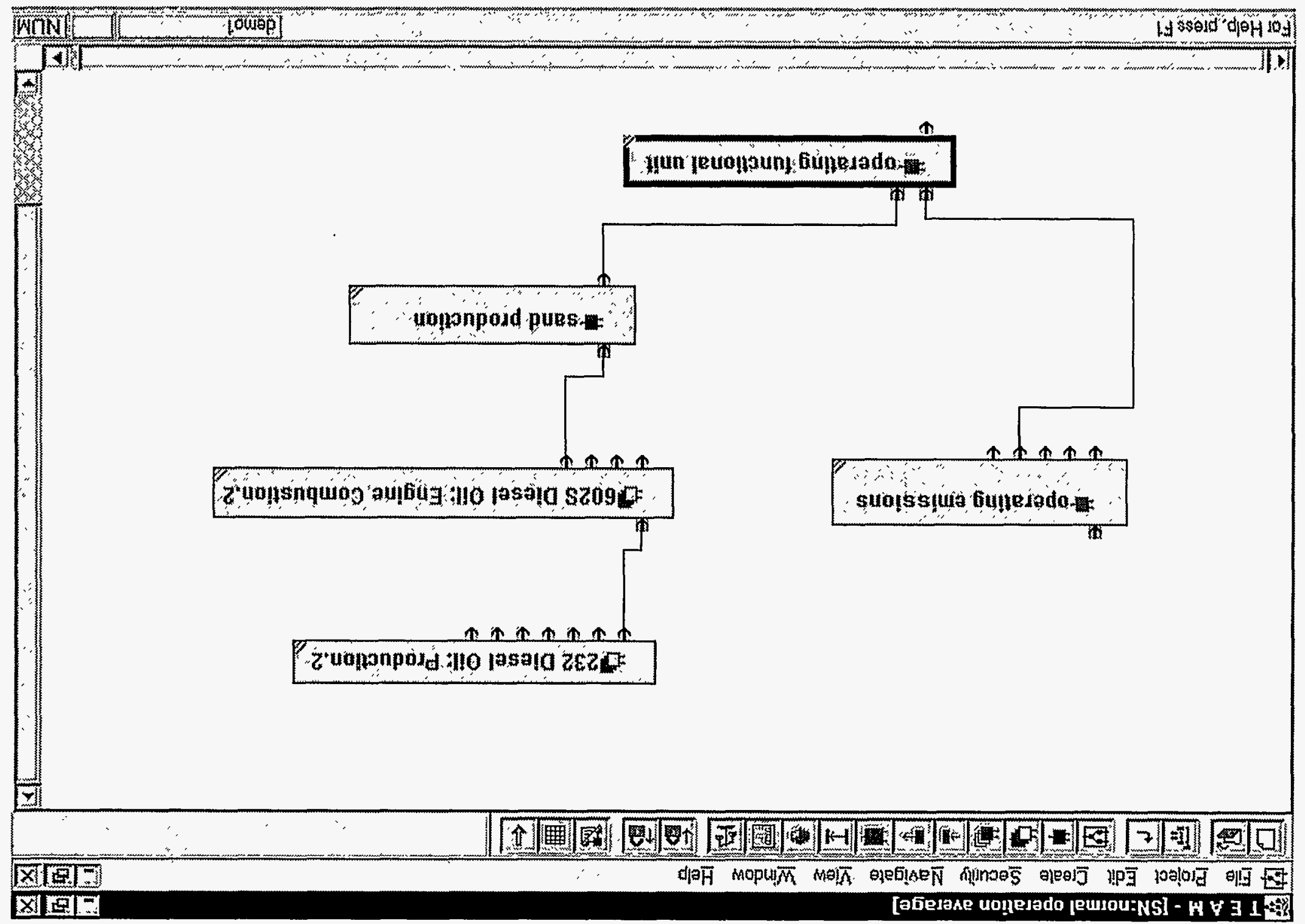




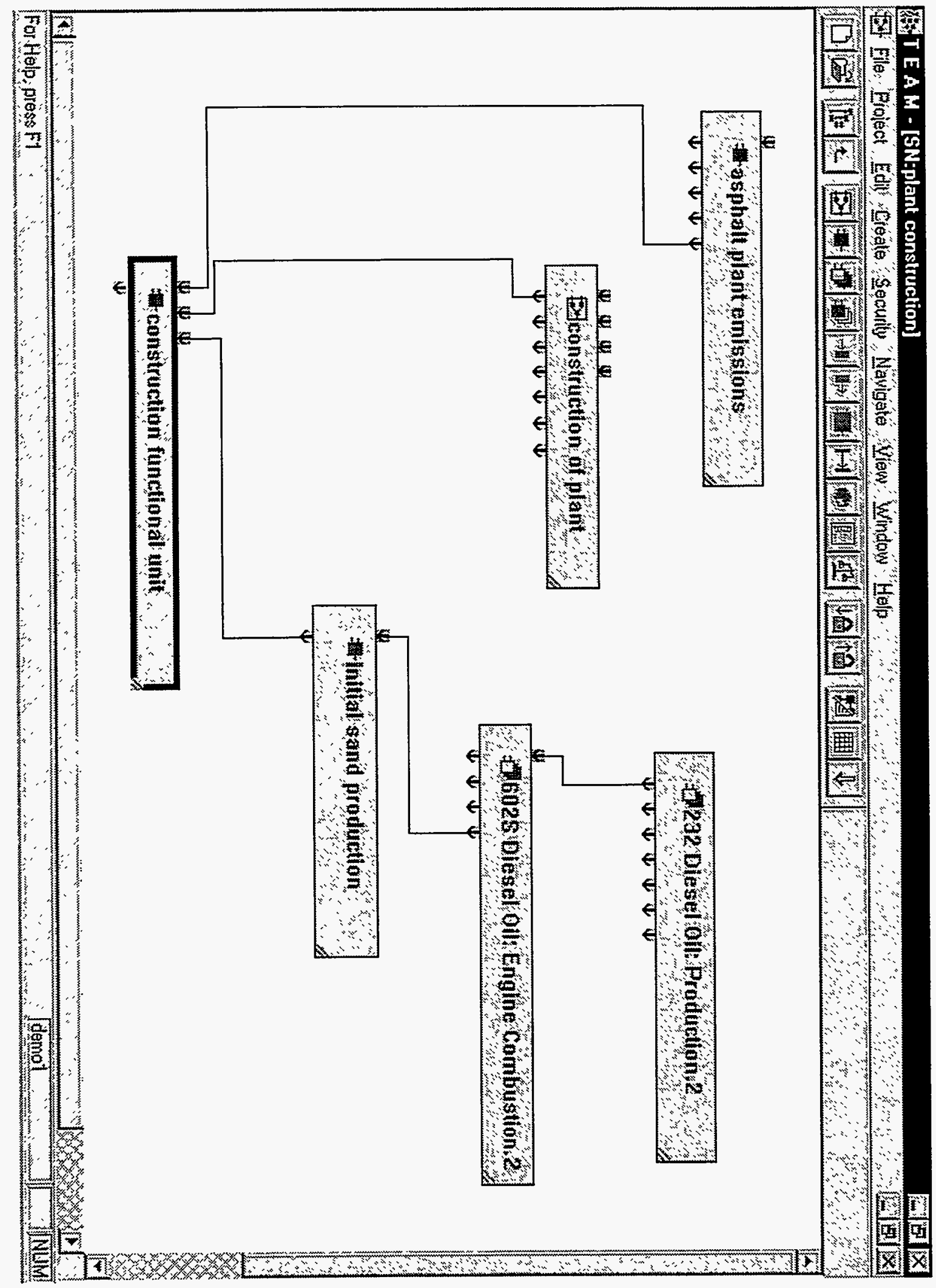




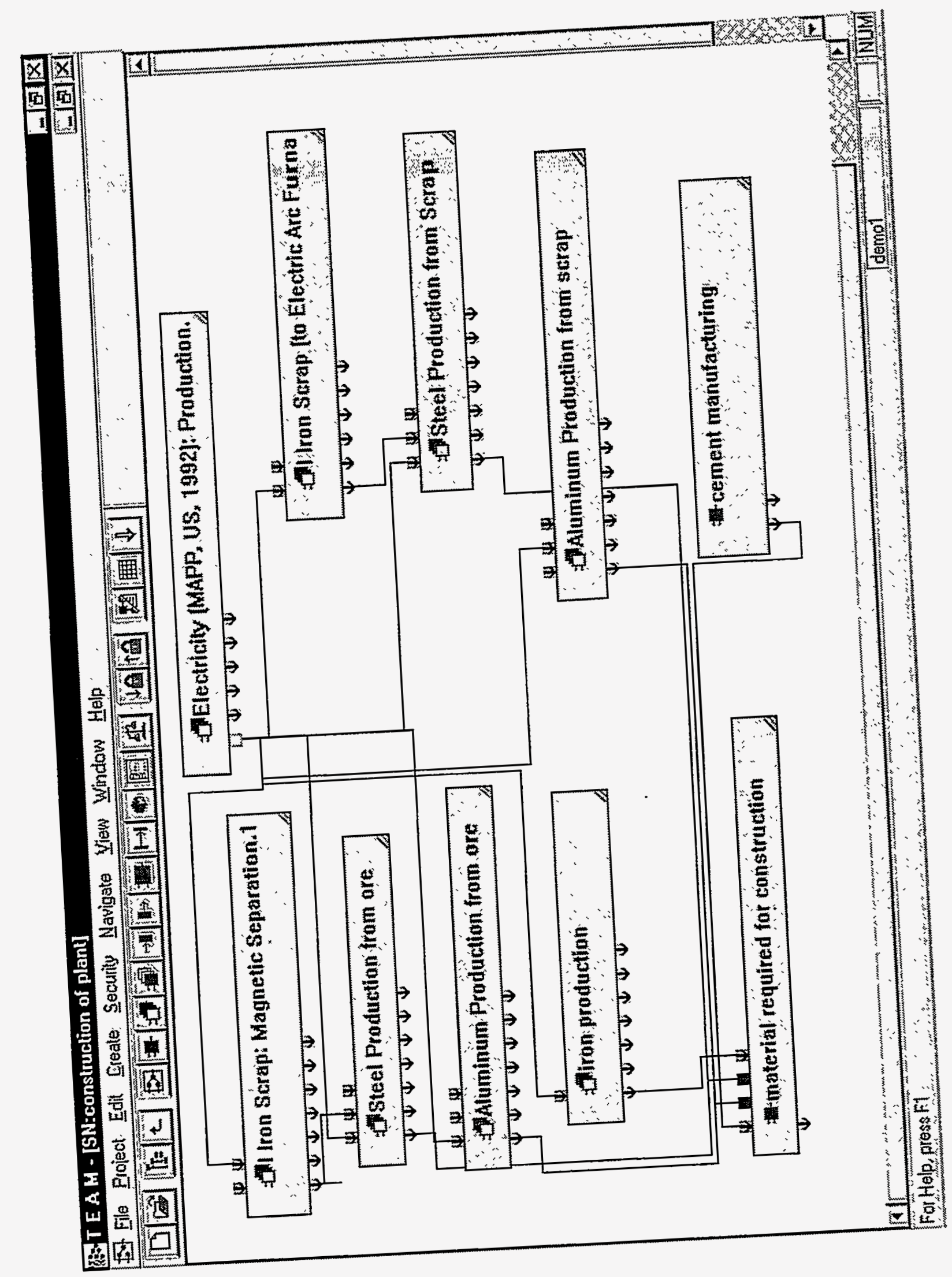




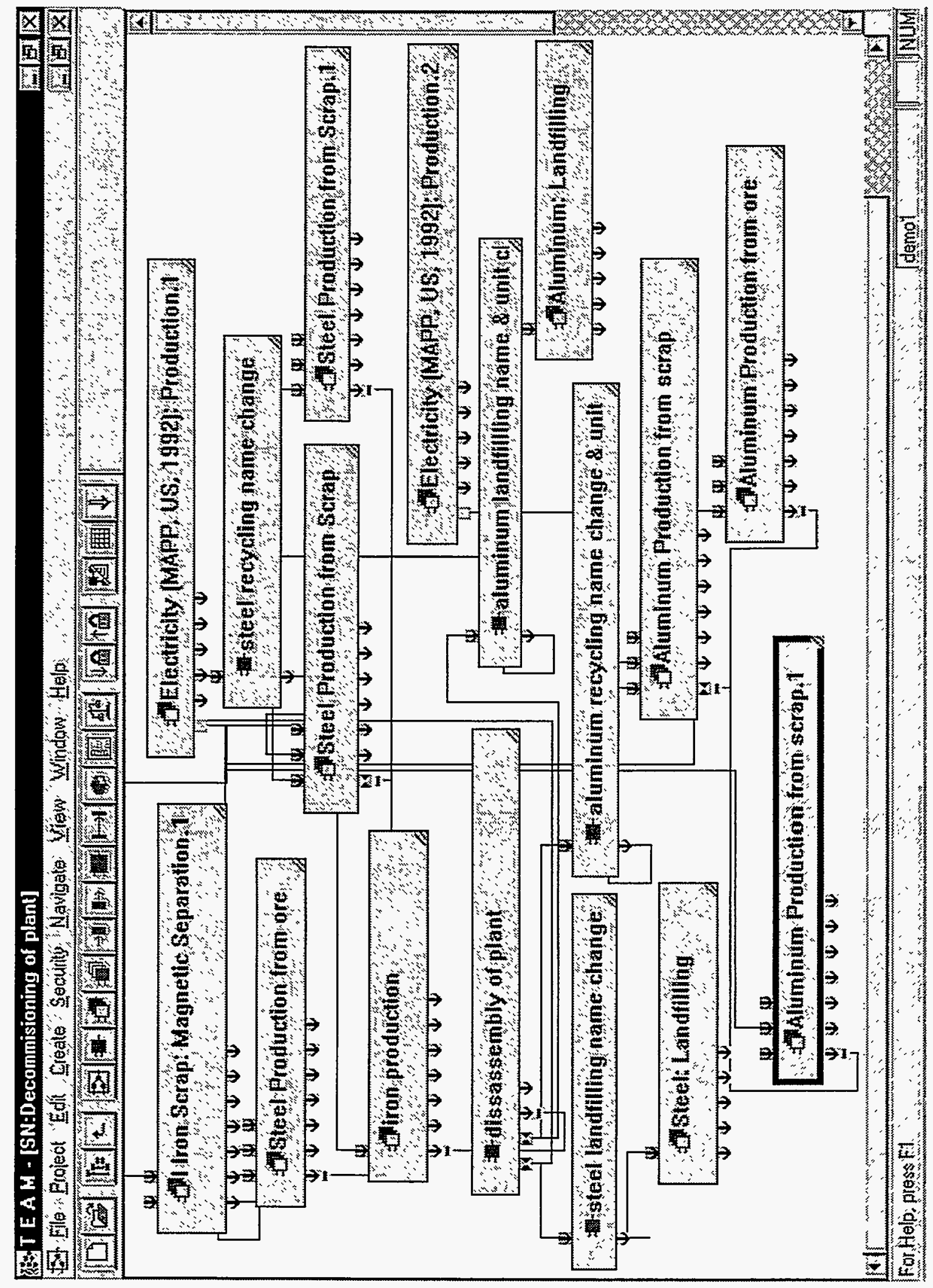




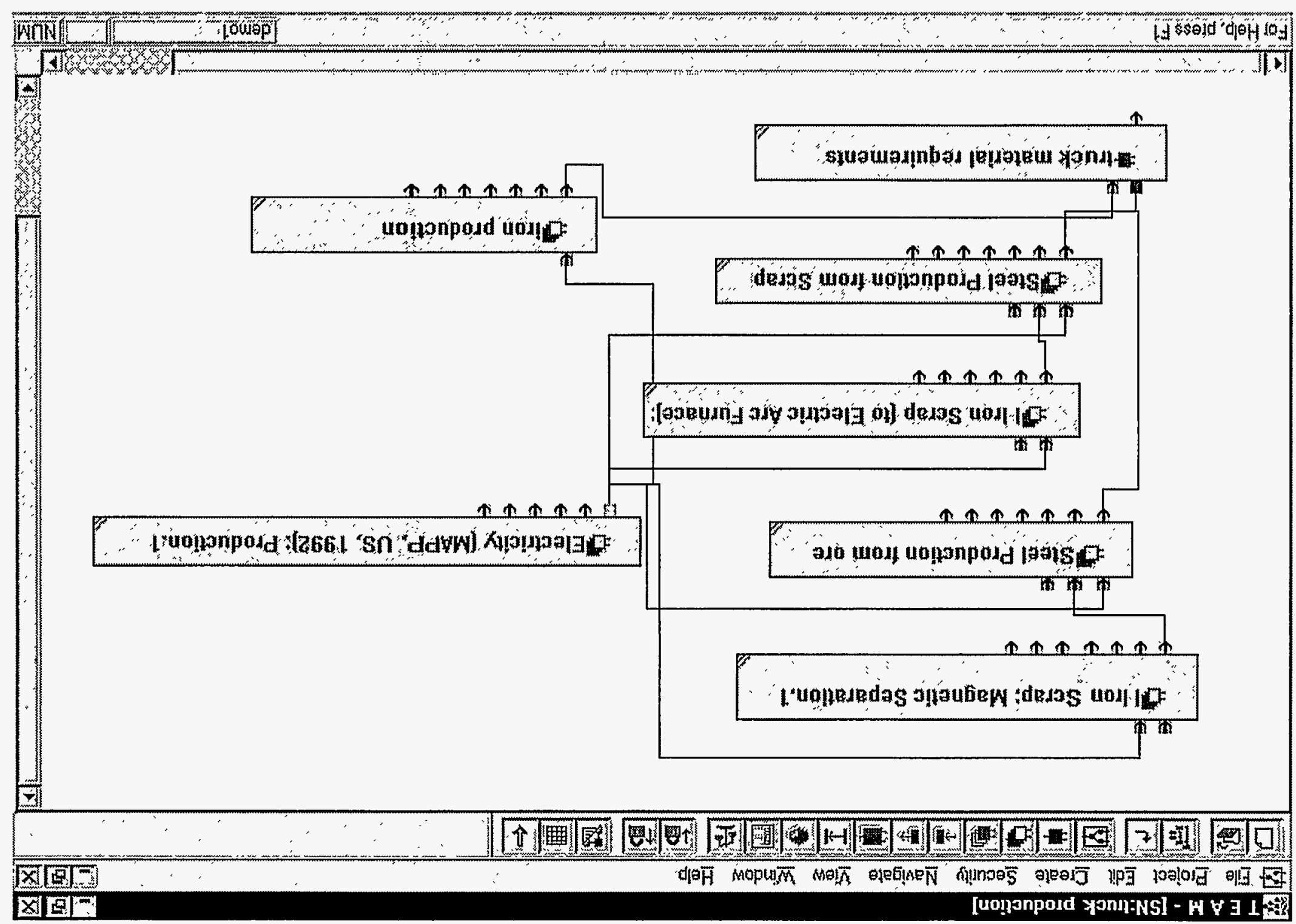




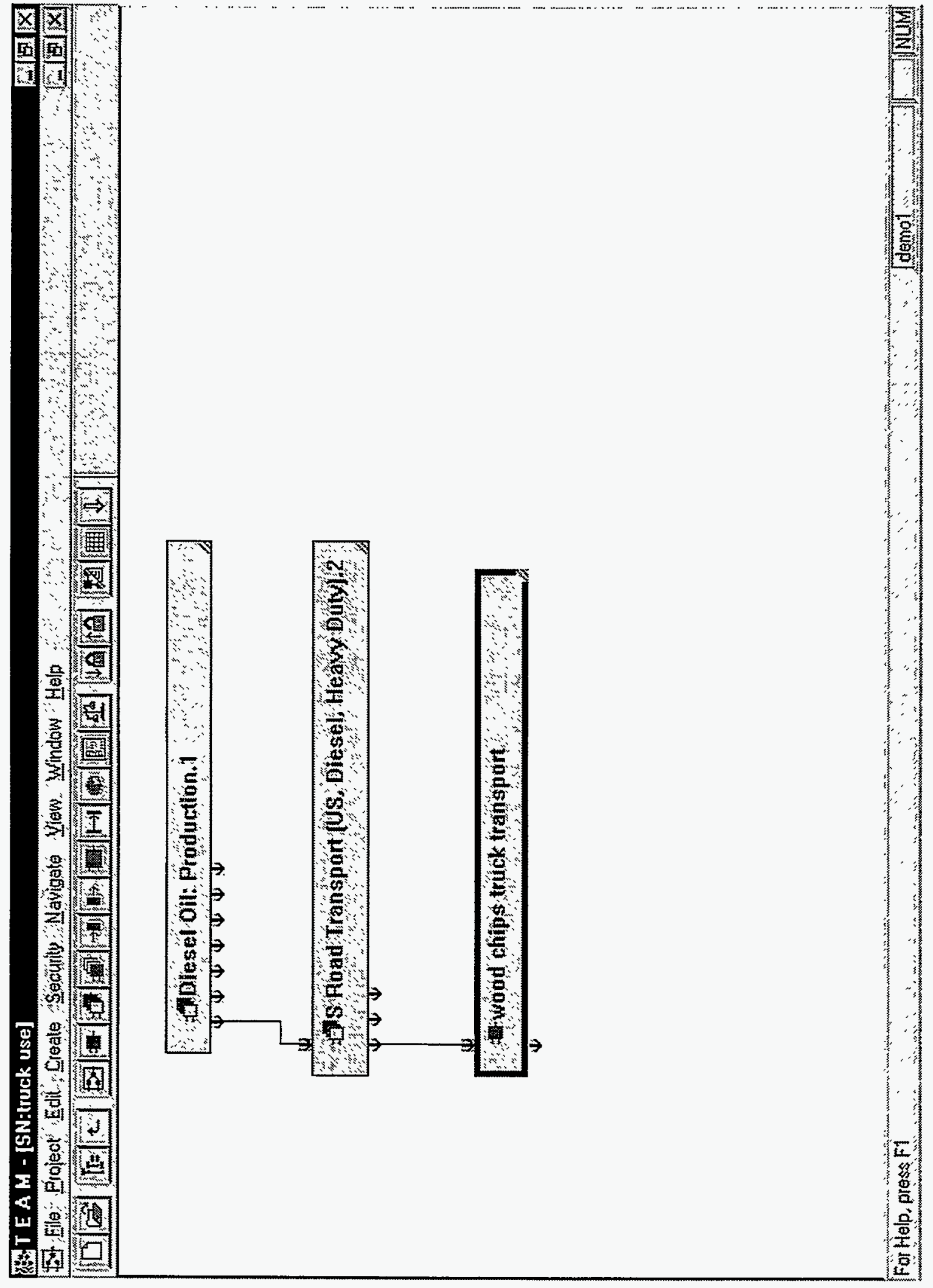




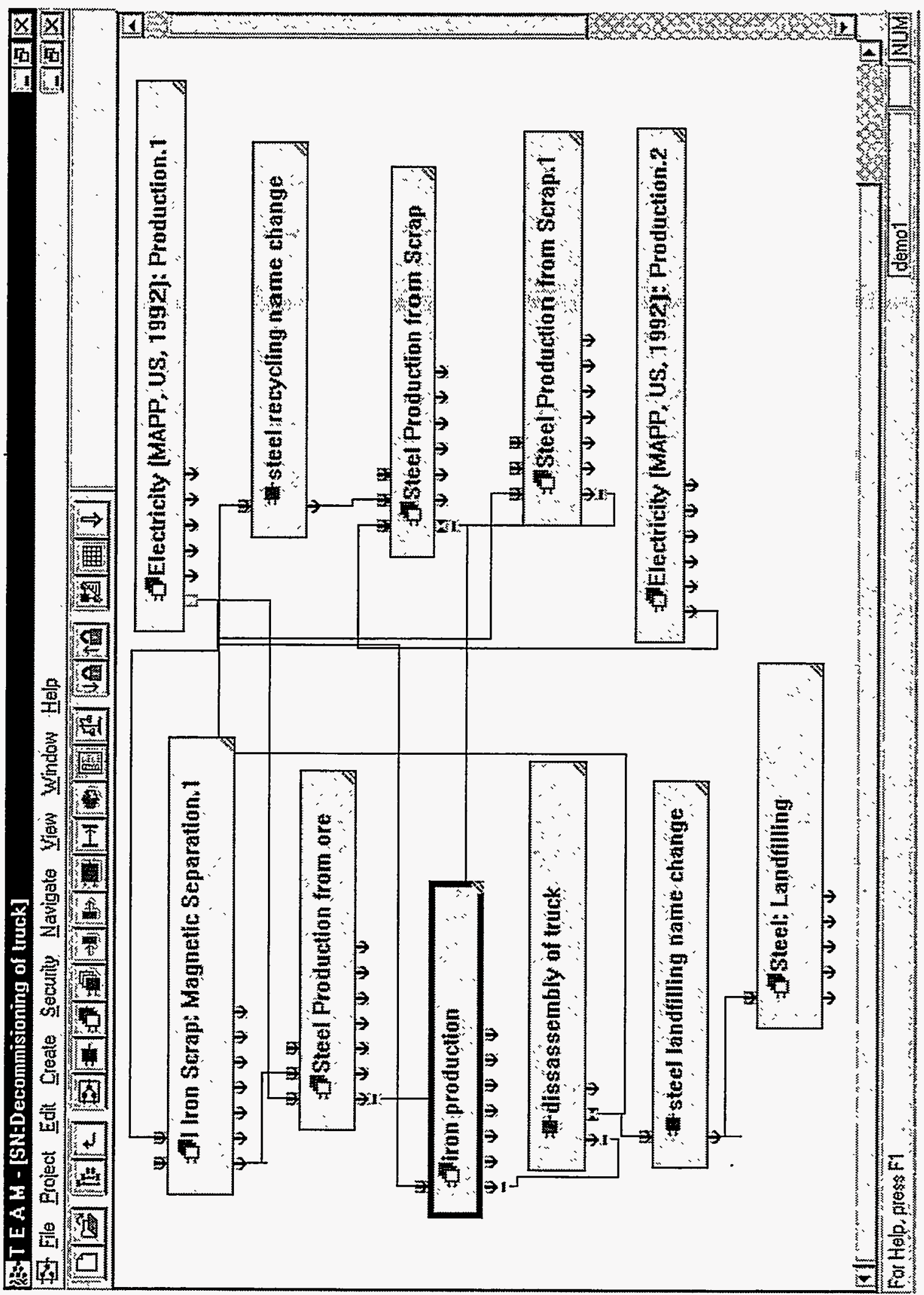




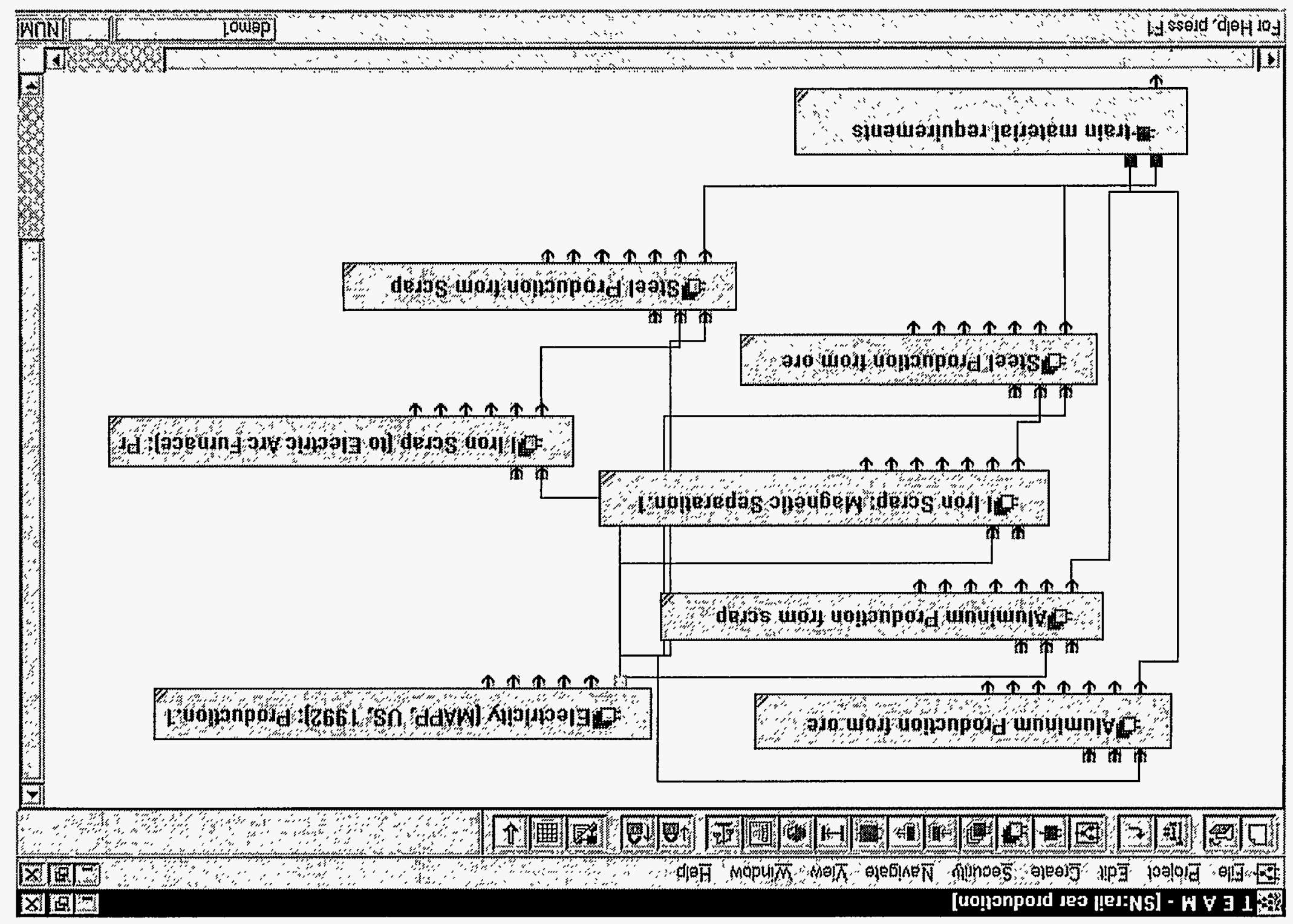




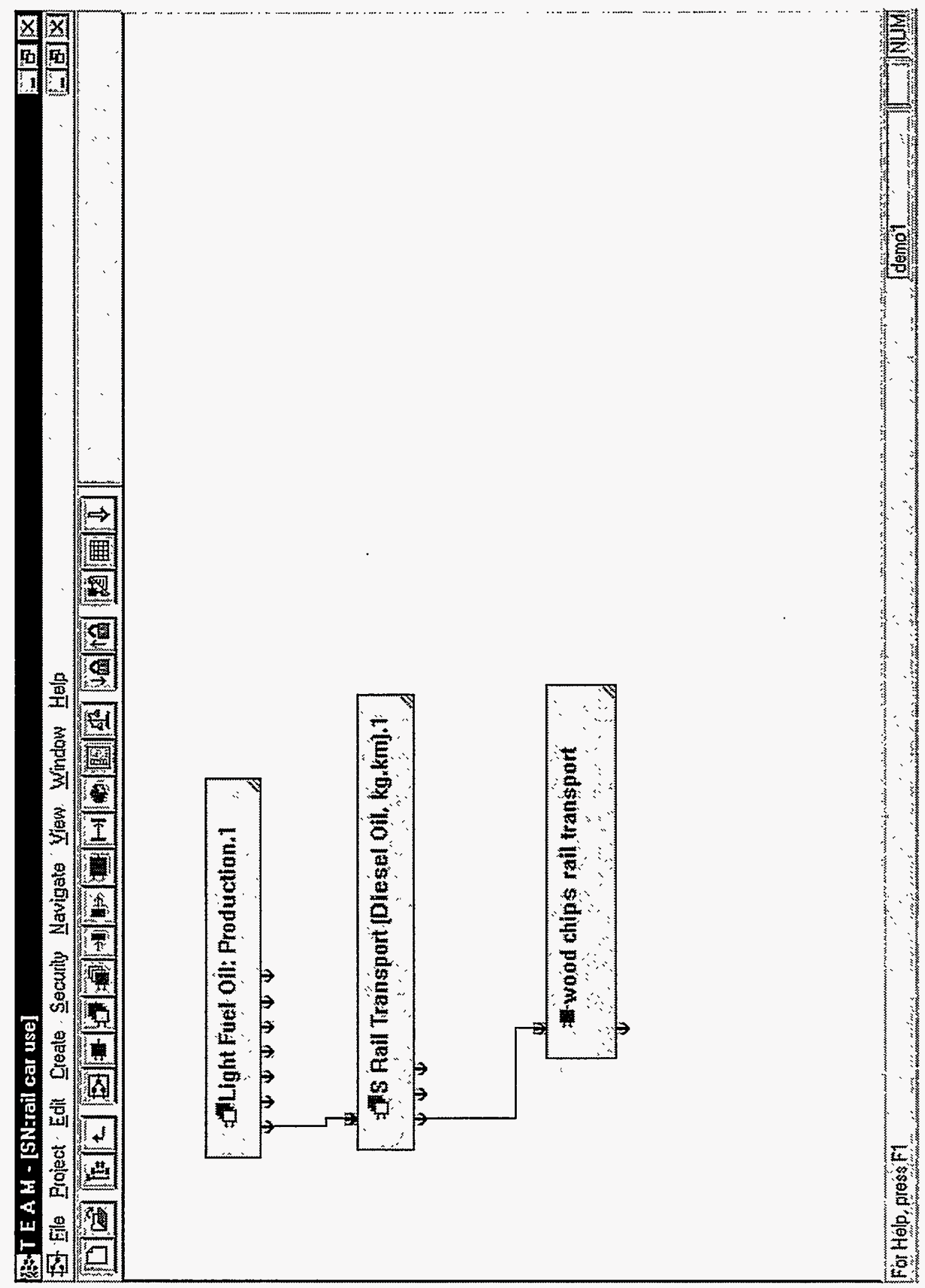




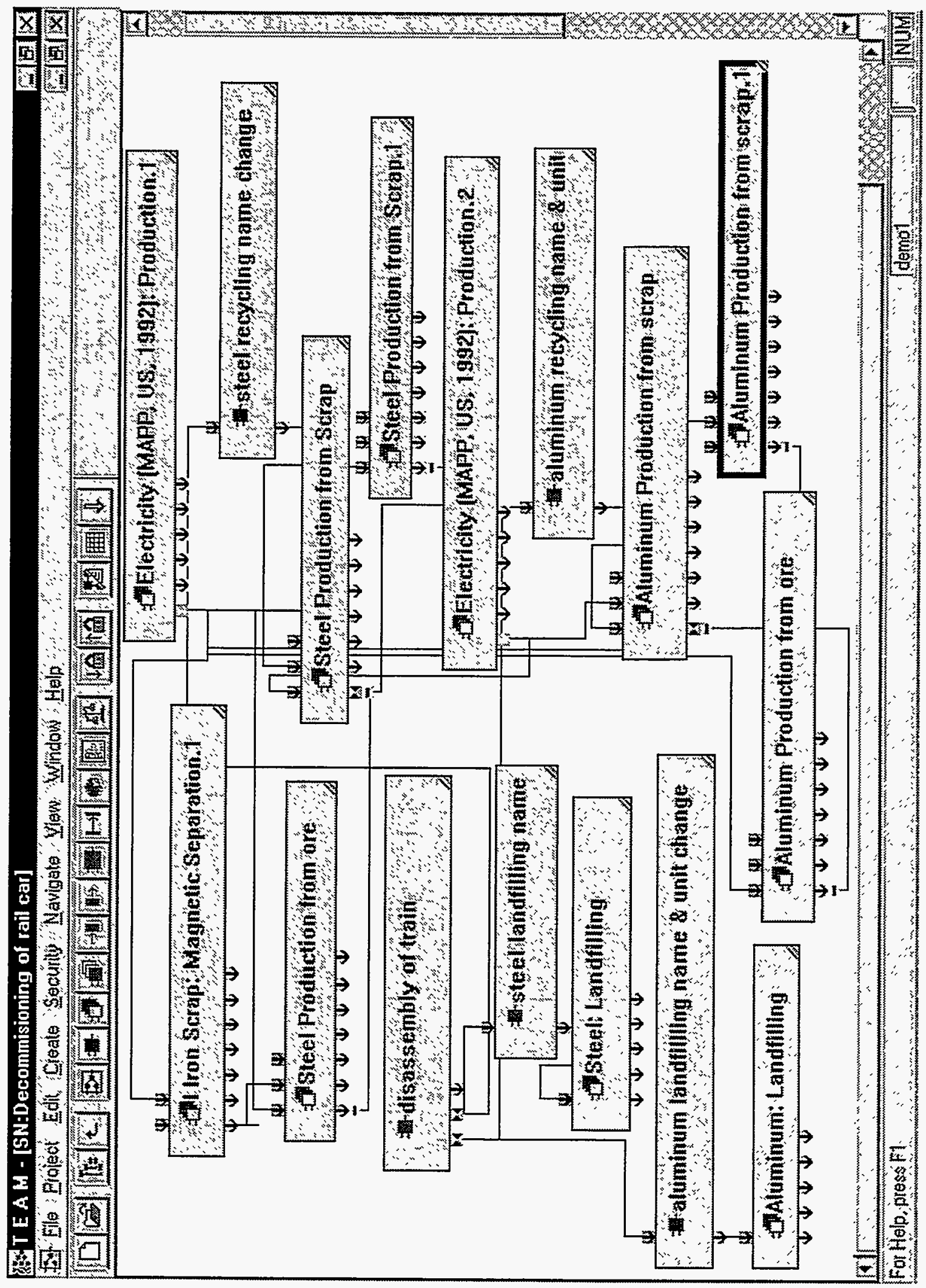


Appendix B: Details of Some DEAM Database Modules 


\begin{tabular}{|l|l|l|l|}
\hline \multicolumn{1}{|c|}{ Material } & \multicolumn{1}{|c|}{ Source } & \multicolumn{1}{c|}{ Content of the Module } & \multicolumn{1}{c|}{ Comment } \\
\hline Steel & $\begin{array}{l}\text { Swiss Federal Office of } \\
\text { Environment, Forests and } \\
\text { Landscape (FOEFL or } \\
\text { BUWAL) Environmental } \\
\text { Series No. 132.p. A80, A83, } \\
\text { A86, A89, A92, A94. }\end{array}$ & $\begin{array}{l}\text { Iron ore mining. Coal } \\
\text { carbonization (distillation in the } \\
\text { absence of air). Hot metal } \\
\text { production, includes sinter plant } \\
\text { and blast furnace. Oxygen } \\
\text { converter steel plant. Hot rolling } \\
\text { of slabs. Cold rolling of coils. }\end{array}$ & $\begin{array}{l}\text { Data representative of the } \\
\text { 1975-1980 period. } \\
\text { US electricity model. }\end{array}$ \\
\hline $\begin{array}{l}\text { Steel } \\
\text { (secondary) }\end{array}$ & See cold rolled steel & $\begin{array}{l}\text { Detinning of steel scrap. } \\
\text { Magnetic separation of steel } \\
\text { scrap from mixed waste. Steel } \\
\text { slab production from the } \\
\text { Electric Arc Furnace (EAF). } \\
\text { Includes the production of } \\
\text { graphite electrodes (3 kg per } \\
\text { metric ton of raw steel). }\end{array}$ & $\begin{array}{l}\text { Data representative of the } \\
\text { 1975-1980 period. } \\
\text { US electricity model. }\end{array}$ \\
\hline Iron (Fe) & See cold rolled steel & $\begin{array}{l}\text { Iron ore mining. Coal } \\
\text { carbonization (distillation in the } \\
\text { absence of air). Hot metal } \\
\text { production, includes sinter plant } \\
\text { and blast furnace. }\end{array}$ & $\begin{array}{l}\text { Data representative of the } \\
1975-1980 \text { period. } \\
\text { US electricity model. }\end{array}$ \\
\hline Steel(electro- \\
galvanized)
\end{tabular}

Table 1: Source of Data for Ferrous Metals 


\begin{tabular}{|c|c|c|c|}
\hline Material & Source & Content of the Module & Comment \\
\hline $\begin{array}{l}\text { Aluminum (Al, } \\
\text { casting alloy) }\end{array}$ & $\begin{array}{l}\text { One OEM casting plant. } \\
\text { In order to preserve the } \\
\text { confidentiality of the data, the } \\
\text { initial data have been } \\
\text { aggregated with secondary data } \\
\text { describing the production of } \\
\text { ancillary materials and energy } \\
\text { carriers consumed by the plant }\end{array}$ & $\begin{array}{l}\text { Refinery of aluminum. } \\
80 \% \text { secondary, } 20 \% \text { primary }\end{array}$ & $\begin{array}{l}\text { Primary data: water emissions } \\
\text { are missing } \\
\text { not included in emission } \\
\text { numbers are the releases } \\
\text { called: } \\
\text { "Recycle/Recovery/Reuse" }\end{array}$ \\
\hline $\begin{array}{l}\text { Aluminum (Al, } \\
30 \% \text { secondary) }\end{array}$ & $\begin{array}{l}\text { 1.) Swiss Federal Office of } \\
\text { Environment, Forests and } \\
\text { Landscape (FOEFL or } \\
\text { BUWAL) Environmental } \\
\text { Series No. } 250 \text { Bern, } 1996 . \\
\text { Page } 83,87-88 \text {. } \\
\text { 2.) EAA (European Aluminium } \\
\text { Association) (primary source } \\
\text { in Buwal) }\end{array}$ & $\begin{array}{l}\text { A mixture of } 30 \% \text { secondary } \\
70 \% \text { primary aluminum, no } \\
\text { further processing. } \\
\text { For primary, Bauxite from } \\
\text { Guinea, Australia and Europe } \\
\text { Bayer Process }\end{array}$ & $\begin{array}{l}\text { Primary: Transport by sea } \\
\text { (Bauxite: } 7917 \mathrm{~km} \text {, Aluminum } \\
\text { Oxide: } 4587 \text { ), barge } \\
\text { (Limestone: } 500 \text { ), rail (AlF3: } \\
\text { 300) and road (NaOH: } 500 \text { ) is } \\
\text { included. Electricity is } \\
\text { included. Secondary: includes } \\
\text { transport }\end{array}$ \\
\hline $\begin{array}{l}\text { Aluminum (Al, } \\
\text { primary) }\end{array}$ & $\begin{array}{l}\text { 1) Swiss Federal Office of } \\
\text { Environment, Forests and } \\
\text { Landscape (FOEFL or } \\
\text { BUWAL) Environmental } \\
\text { Series No. } 250 \text { Bern, } 1996 . \\
\text { Page } 83 . \\
\text { 2) EAA (European Aluminium } \\
\text { Assocation) (primary source in } \\
\text { Buwal) }\end{array}$ & $\begin{array}{l}\text { Bauxite from Guinea, Australia } \\
\text { and Europe Bayer Process } \\
\text { Electricity model from } \\
\text { European Aluminum } \\
\text { Association: } \\
\quad-66.3 \% \text { hydro } \\
\text { - } 14.8 \% \text { nuclear } \\
-13.6 \% \text { coal } \\
-3.2 \% \text { natural gas } \\
-2.1 \% \text { oil }\end{array}$ & $\begin{array}{l}\text { Transport by sea (Bauxite: } \\
7917 \mathrm{~km} \text {, Aluminum Oxide: } \\
\text { 4587), barge (Limestone: } 500 \text { ), } \\
\text { rail (AlF3: } 300 \text { ) and road } \\
\text { (NaOH: 500) is included. } \\
\text { Electricity is included. }\end{array}$ \\
\hline
\end{tabular}

Table 2: Source of Data for Non Ferrous Metals 


\section{COAL PRE-COMBUSTION}

Coal pre-combustion includes extraction of coal from the ground, then cleaning and preparation of the coal for use. Transportation to the point of use is not included at this stage.

\section{COAL MINING:}

Materials and energy consumed in mining and cleaning of coal comes from 1987 Census Bureau data (DeLuchi, Emissions of Greenhouse Gases from the Use of Transportation Fuels and Electricity, 1993. Volume 2. Appendix F. Table F-2).

Emissions due to mining coal are from the combustion of diesel oil of mining equipment (except methane which is released directly from the mine). All emissions factors come from AP-42 Mobile Sources Volume II, January 1991.

In terms of water effluents, DOE states that water effluents due to mining are unquantifiable, however water effluents from this type of operation generally do not cause global impacts ${ }^{1}$.

\section{Cleaning AND PREParation:}

Cleaning and preparing coal may involve many processes, including beneficiation, which removes sulfur and mineral matter so that stringent Federal emissions limits during combustion are met. However,

- there are not enough specific data as to the percentage of coal that goes through these processes; and

- the amount of energy consumed in these processes is negligible compared to the amount of energy that is generated from coal combustion ${ }^{2}$.

Therefore, coal cleaning and preparation steps are omitted from the model.

Water Effluents:

Water effluents coming from pre-combustion processes are considered negligible for this study. In general, the only water effluents coming from pre-combustion are those from mining (and refining) the fuels that are used to transport materials.

'DOE, March 1983. Energy Technology Characterizations Handbook section on "Coal Technologies."

${ }^{2}$ DeLuchi, 1993. Emissions of Greenhouse Gases from the Use of Transportation Fuels and Electricity, Appendix F. 


\section{COAL ELECTRICITY PRODUCTION}

Production of electricity from coal includes coal pre-combustion, transportation of the coal to the utility, coal combustion (including control technologies) and coal ash management. Data on coal pre-combustion is listed separately, therefore, this section only describes the coal transport, combustion, and ash management.

\section{Transportation of CoAL from StTe of Extraction to PoWer Plant}

Coal may be transported by different transportation means, including rail, road, pipeline, and river. The expression used to describe the energy intensity of transporting coal (or any other material) is Btu per tonmile. This is calculated as:

$$
\frac{E}{T * M} \text { (see note 3) }
$$

where:

$E$ is total Btu used by the mode of transport and the energy used for the backhaul (assuming the return trip is empty);

$\mathrm{T}$ is total tonnage of the transported material; and

$\mathrm{M}$ is the distance the material was carried.

It is safe to assume that for the most part, the carrier returns empty. For example, $91 \%$ of the unit train cars that carry coal return empty to the mine (DeLuchi, 1993), and trucks return empty unless they can find a similar product to transport back. Therefore, all transportation data will assume a one-way haul.

$\underline{\text { Rail: }}$

The 1987 national average length of haul for coal by means of rail is 490 miles $^{4}$. It is assumed that diesel fuel is used for rail transportation ${ }^{5}$. DeLuchi (1993) presents energy consumed in coal transportation by rail from a few sources (U.S. Department of Energy (1983), U.S. Congressional Research Service (CRS) (1977), and Argonne National Laboratory (ANL) (1982)). The energy consumed is averaged out to be 589 Btu per ton-mile.

Truck:

DeLuchi (1993) is in accordance with the DOE Energy Technology Characterizations Handbook (1983) on an average haul distance of 60 miles for a round trip of coal delivery. It is assumed that diesel fuel is used for truck transportation. DeLuchi (1993) estimates energy consumed in coal transportation by truck from a few sources (U.S. Department of Energy (1983), U.S. Congressional Research Service (CRS) (1977), and Argonne National Laboratory (ANL) (1982), and Rose (1979)). The energy consumed is averaged out to be 2349 Btu per ton-mile.

\footnotetext{
${ }^{3}$ DeLuchi, 1993. Emissions of Greenhouse Gases from the Use of Transportation Fuels and Electricity, Appendix E.

${ }^{4}$ DeLuchi, 1993. Emissions of Greenhouse Gases from the Use of Transportation Fuels and Electricity. EIA, 1988. Coal Distribution.

${ }^{5}$ DeLuchi, 1993. Emissions of Greenhouse Gases from the Use of Transportation Fuels and Electricity, Appendix F.
} 
Ship:

The national average length of haul for coal by means of water is 450 miles $^{6}$. DeLuchi (1993) estimates energy consumed in coal transportation by ship from a few sources (U.S. Department of Energy (1983), U.S. Congressional Research Service (CRS) (1977), and Argonne National Laboratory (ANL) (1982), and Rose (1979)). The energy consumed is averaged 539 Btu per ton-mile.

\section{Slurry Pipeline:}

In general, coal slurry pipeline is a highly reliable (99\%) source of transportation, and can last longer than 20 or 30 years. It is the cleanest and safest coal delivery system to power plants. Data for energy consumed in coal transportation by slurry pipeline was presented in Emissions of Greenhouse Gases from the Use of Transportation Fuels and Electricity ${ }^{7}$ (1993) over a few sources: U.S. Department of Energy (1983), Banks (1977) and Argonne National Laboratory (ANL) (1982). The energy consumed for this mode of transport is averaged out to be $668 \mathrm{Btu}$-power per ton-mile. Included in this average is energy used for slurry preparation, pipeline pumping, dewatering facilities, and specifically, energy used in the Black Mesa Pipeline, which runs 273 miles from the Black Mesa Coal Mine in Arizona to the Mohave Power Plant in Laughlin, Nevada. DeLuchi (1993) estimates that the average length of haul for a pipeline is 300 miles, including the pipeline itself, tramway transportation, and conveyor belts.

\section{Transportation Emissions:}

Emissions from all of the different types of transportation methods are included in the model. The emission factors for the different transportation methods are shown elsewhere.

\section{COAL COMBUSTION}

Energy consumed and emissions associated with combustion of coal in utility boilers comes from a variety of sources. Emissions and total coal burned were obtained from the 1994 Interim Inventory based on the Form EIA-767 data ${ }^{8}$ (the Interim Inventory 1994). Emissions factors for pollutants not provided in the Interim Inventory (1994) are obtained from AP-42 (1995).

Emissions are presented for each individual firing configuration. Because firing configurations have varying combustion requirements (coal burning temperatures, firing methods, and emissions control equipment, etc.), they emit varying amounts of pollutants.

The firing configurations included in the model are:

- $\quad$ pulverized coal fired, dry bottom and wall fired;

- pulverized coal fired, dry bottom and tangentially-fired;

- pulverized coal-fired and wet bottom;

- spreader stoker;

- fluidized bed combustor; and

- cyclone furnace.

${ }^{6}$ DeLuchi, 1993. Emissions of Greenhouse Gases from the Use of Transportation Fuels and Electricity. U.S. Department of Army, 1988, 1989. Waterborne Commerce of the United States,

${ }^{7}$ DeLuchi, 1993. Emissions of Greenhouse Gases from the Use of Transportation Fuels and Electricity.

${ }^{8}$ Database provided by EPA. 
The Interim Inventory (1994) provides actual air emissions (VOC's, NOx, CO, SOx, and PM-10) by specific type of coal (bituminous, subbituminous, and lignite) and by furnace type. The firing types provided are also identified by a Source Classification Code (SCC). Each firing type was placed into a broader category of firing configurations (identified in AP-42), using SCC numbers. The following table presents the firing types provided by the Interim Inventory (1994), and how they were placed in the firing configuration category, based on SCC numbers.

\begin{tabular}{|l|l|}
\hline \multicolumn{1}{|c|}{ Firing Configuration (AP-42 1995) } & \multicolumn{1}{|c|}{ Firing Types (Interim Inventory 1994) } \\
\hline \hline Pulverized coal fired, dry bottom, wall fired & Front Furnace \\
& Arch Furnace (50\%) \\
& Rear Furnace \\
& Spreader Stoker (80\%) \\
& Opposed Furnace \\
& Vertical Furnace \\
\hline Pulverized coal fired, dry bottom and tangentially-fired & Tangential Furnace \\
\hline Pulverized coal-fired, wet bottom & Arch Furnace (50\%) \\
\hline Spreader stoker & Spreader Stoker (20\%) \\
\hline Fluidized bed combustor & Fluidized Bed \\
\hline Cyclone furnace & Cyclone \\
\hline
\end{tabular}

Several steps were made to obtain actual emissions in pounds per ton of each type of coal. The tonnage for each emission provided by the Interim Inventory (1994) database was summed for each firing configuration. This number was divided by the total amount of coal consumed for each firing configuration, to obtain actual emissions per firing configuration, per type of coal.

Where actual emissions data were not available, such as $\mathrm{N}_{2} \mathrm{O}$, methane, and trace elements, emissions factors were obtained from AP-42 (1995) and a weighted average was used for each firing configuration.

The model also takes into account all carbon dioxide emissions, which are calculated by multiplying 36.7 by the percent weight of carbon content in coal. Fixed carbon content percentages of different coal samples are given in provided Babcock and Wilcox ${ }^{11}$ for anthracite, bituminous coal, subbituminous coal, and lignite. Averaged values, and $\mathrm{CO}_{2}$ emissions factors (in $\mathrm{g} / \mathrm{kg}$ coal) are provided in the table below:

\begin{tabular}{|c|c|c|}
\cline { 2 - 3 } \multicolumn{1}{c|}{} & Fixed Carbon Content \% & CO2 Emissions Factor (g/kg) \\
\hline Anthracite & (see footnote 12) & 2,840 \\
\hline Bituminous & 85 & 3,120 \\
\hline Subbituminous & 75 & 2,753 \\
\hline Lignite & 70 & 2,569 \\
\hline
\end{tabular}

Finally, the model takes the weighted average of each of the firing configurations for each type of coal. For example, the emissions from the spreader stoker for bituminous coal combustion are omitted from the model, since bituminous coal combusted in the spreader stoker is a negligible representation of all of the bituminous coal fed into the firing configurations.

\section{Emissions Control Technology:}

\footnotetext{
${ }^{9}$ About half of the arch furnace boilers had SCC numbers for dry-bottom wall-fired units and the other half for wetbottom units.

${ }^{10}$ An estimated $80 \%$ of the spreader stoker boilers had SCC numbers for dry-bottom wall-fired units and the other $20 \%$ belonged in the spreader stoker category of firing configurations.

"Babcock \& Wilcox, 1992. Steam, 40 ${ }^{\text {th }}$ ed. Babcock \& Wilcox Company, Barberton, OH.

${ }^{12}$ Carbon content for anthracite is not needed for the calculation since the EPA Air Emissions Factors provided the emission factor directly.
} 
Because there is actual plant data for VOCs, $\mathrm{NOx}, \mathrm{CO}, \mathrm{SO}$, and particulate matter, emission control technologies for some of the major pollutants of concern, such as NOx and SOx, are already taken into account.

Lime and limestone, used for flue gas desulfurization (FGD), are modeled. Coal utility plants use different methods for scrubbing, such as limestone slurries and dry spraying, and use as the primary FGD materials lime and limestone. Quantities of lime and limestone vary, depending on the type of coal, the molar ratio needed to scrub the SOx, and the percentage of SOx (by weight) in the coal. Each type of coal was modeled according to the general scrubbing material for that type of coal and based on its percentage by weight of SOx. Data on scrubbing, molar ratios, and technologies were collected from a source at a coal utility plant in North America (1996), a source at American Electric Power Company (1997) and from the DOE Energy Information Administration Electric Power Annual 1994, Vol. II, November 1995.

\section{Water Effluents:}

Coal combustors use water for boiler makeup, treatment of fumes, and slag cooling. However, it is assumed that most of the water is recycled in the facility. Therefore, water effluents generated as a result of combustion of coal are negligible in this model.

\section{Post-Combustion OF COAL}

The coal combustion process produces waste that must be disposed of off-site, including coal ash, resulting from coal combustion, and sludge, resulting from flue gas desulfurization (FGD). In 1984, $69 \times 10^{6}$ tons and $16 \times 10^{6}$ tons of coal ash and FGD sludge, respectively, were generated from electrical facilities ${ }^{13}$. Energy and emissions to remove coal ash and FDG sludge are modeled. Since the quantity of FDG sludge is approximately $25 \%$ the amount of coal ash, all energy and emissions to remove and dispose of FDG sludge are considered to be about $25 \%$ of those found for the disposal of coal ash.

Energy to transport FDG sludge and coal ash from the plant to their respective storage locations is modeled. The moisture content of coal ash (in \% weight of ash) at the point it is removed from the silo is assumed to be approximately $17 \%$ (moisture content may be anywhere from $8 \%$ to $25 \%)^{14}$. The average energy consumed to place ash from the silo into the truck, 0.143 kilowatt hours ${ }^{15}$ per ton, is very minimal, as most of the work is due to gravitational force (ash falling from the shoot).

The distance from the power plant to the coal ash and FGD sludge landfills is assumed to be one mile ${ }^{16}$.

The trucks used to transport the materials are tandem trucks, filled based on weight of the material. The tandem truck carries an actual payload of about 27.6 short tons, and consumes 0.038 gallons of diesel fuel per short ton ${ }^{17}$ of material.

\footnotetext{
${ }^{13}$ U.S. EPA, October 1987. Wastes from the Combustion of Coal by Electric Utility Power Plants (from DeLuchi, 1993. Emissions of Greenhouse Gases from the Use of Transportation Fuels and Electricity, Appendix F).

${ }^{14}$ From American Power Plant Data, 1996. Power plant information is confidential data collected by Ecobalance.

${ }_{16}^{15}$ From American Power Plant Data, 1996.

${ }^{16}$ From American Power Plant Data, 1996.

${ }^{17}$ At an average of $4 \mathrm{~L}$ of diesel fuel to transport 28 metric tons per load to the coal ash monofill, from American Power Plant Data, 1996.
} 
This section includes pre-combustion data for the refined petroleum products heavy fuel oil, diesel oil, and gasoline. The pre-combustion steps includes extraction of crude oil from the ground, transportation of the crude oil to a refinery, and refining the crude oil into finished refinery products. Transportation of the finished refinery products to the point of use is not included at this stage.

\section{GEOGRAPHICAL BOUNDARIES}

The modeling of refined petroleum products production includes worldwide crude oil extraction and U.S. refinery operations. Foreign crude oil extraction and transportation to the United States is modeled because half of the U.S. supply of crude oil is imported. The transport of finished refinery products into the U.S. is not studied because foreign refinery products only accounts for a small percent of the total finished refinery products used in the U.S. in $1994^{18}$, and may be accounted for under domestic refinery production. In addition, domestic refinery data are more accurate and reliable.

\section{CRUDE OIL EXTRACTION}

There are three separate methods for crude oil extraction and recovery: onshore production, offshore production, and thermal enhanced recovery, which entails the underground injection of carbon dioxide or steam produced by natural gas boilers ${ }^{19}$. All of these methods are modeled.

Heater treater separators are used to separate the crude oil, natural gas, and water mixture that is extracted. As natural gas is produced as a co-product of crude oil production, emissions will be allocated between gross natural gas and crude oil production on a mass based method. The emissions associated with the venting and flaring of some of the natural gas extracted from the well will also be accounted for.

The inflows associated with the three different methods of crude oil extraction include electricity used in pumping, and natural gas used as fuel to run the heater treater systems. Outflows include air emissions, water effluents, and solid waste.

\section{TRANSPORTATION}

The United States is broken up into Petroleum Administration for Defense Districts (PADDs) in order to insure that each region or PADD is supplied with enough petroleum for strategic defense reasons. The transportation distances used in this report will be averaged across all of the PADDs. The amount of foreign and domestic crude oil transported into each PADD will be estimated from refinery receipts of crude oil which is known for each PADD ${ }^{20}$.

${ }^{18}$ EIA, May 1995, Petroleum Supply Annual 1994 Volume 1.

19 Shares of each production type were obtained from the Oil \& Gas Journal Database, using numbers obtained in 1994. Note that the Other Enhanced/Advanced category includes all advanced crude oil extraction techniques except water flooding. It will be assumed that the emissions associated with thermal advanced recovery as listed by Tyson et al. (November 1993, Fuel Cycle evaluations of Biomass-Ethanol and Reformulated Gasoline) will apply to the percentage of wells operating with the other Enhanced/Advanced techniques obtained from the Oil \& Gas Journal Database.

211 Source: EIA Petroleum Supply Annual 1993, Vol. 1. 1993 data was used because that was the latest year for which information used to calculate transportation distances could be found (see Section 3.3.2). 
Distances used to model transportation of are based on national averages, obtained from the following types of data and methods of calculation:

\section{Domestic Tanker and Domestic Barge $e^{21}$ :}

Army report lists tons and ton-miles of crude oil transported by tanker and barge on all United States waterways. Average miles are calculated by dividing total ton-miles traveled by total tons transported. This is done separately for both tanker and barge.

\section{Domestic Pipeline ${ }^{22}$ :}

Association of Oil Pipelines lists total ton-miles of crude oil carried in domestic pipelines. Average miles are calculated by dividing total ton-miles of crude oil, carried in domestic pipelines, by tons of crude oil received at refineries via pipeline. Foreign pipeline is calculated the same way.

\section{Domestic Raili3.}

Association of Oil Pipelines lists total ton-miles of crude oil carried by rail in the United States. Average miles are calculated by dividing total ton-miles of crude oil, carried by rail, by tons of crude oil received at refineries via railroad tank cars.

\section{Domestic Truck ${ }^{24}:$}

Association of Oil Pipelines lists estimated total ton-miles of crude oil transported by motor carriers in the United States. Average miles are calculated by dividing total ton-miles of crude oil, transported by motor carriers, by tons of crude oil received at refineries via truck.

\section{Foreign Tanker ${ }^{25}$ :}

The Petroleum Supply Annual lists imports of crude oil by country for each PADD (in barrels). PADD I crude oil is assumed to all arrive at New York. PADD II and III oil is assumed to arrive at Houston. PADD V oil is assumed to arrive at Los Angeles. PADD IV does not receive any foreign oil other than Canada.

${ }^{21}$ Source: Waterborne Commerce of the United States, Calendar Year 1993, Part 5 - National Summaries. Department of the Army, Corps of Engineers.

22 Source: Association of Oil Pipelines, using data from Annual Report (Form 6) of oil pipeline companies to the Federal Energy Regulatory Commission. Energy Information Administration, Petroleum Supply Annual, 1993, Vol. 1.

${ }^{23}$ Source: Association of Oil Pipelines, using data from Carload Way Bill Statistics, Report TD-1, Department of Transportation, Federal Railroad Administration, annual, and Freight Commodity Statistics, Association of American Railroads, annual. Energy Information Administration, Petroleum Supply Annual, 1993, Vol. 1.

24 Source: Association of Oil Pipelines, using data from Financial and Operating Statistics, American Trucking Association, Inc. Energy Information Administration, Petroleum Supply Annual, 1993, Vol. 1.

${ }^{25}$ Source: DeLuchi, M. A., Emissions of Greenhouse Gases from the Use of Transportation Fuels and Electricity, Vol. 2 Argonne National Laboratory, 1993. Energy Information Administration, Petroleum Supply Annual, 1994, Vol. 1. 
Nautical miles between ports of origin and United States ports (New York, Houston, and Los Angeles) are given in DeLuchi's study, based on information from the Defense Mapping Agency ${ }^{26}$. From this information a weighted average is calculated, for each $\mathrm{PADD}$, by multiplying barrels imported from each country by the distance from that country to the specified United States port of entry. These results, in barrel-miles for each PADD, are added together and then divided by the total number of barrels imported to get an average distance in miles traveled by the foreign tankers.

\section{CRUde OIL Refining}

The inflows associated with refining include crude oil, natural gas, LPG, steam, electricity, and $\operatorname{coal}^{27}$. Outflows for this process include air emission ${ }^{28}$, water effluents, and solid waste.

Allocation of refining processes must be addressed. Petroleum refineries produce a number of different products from the amount of crude oil that they receive. Additional complexity is introduced by the fact that the refinery product mix is variable, both among refineries and even with time for a given integrated refinery.

The methodology used in order to allocate total refinery energy consumption and total refinery emissions to the production of different refinery products is described as follows:

1. Calculate the percent of total refinery energy used by each different process within the refinery.

2. Calculate the refinery products share of each process' energy consumption.

3. Multiply the two results in order to get the percent of total refinery energy allocated to the refinery product production for each individual process. Adding the results of each process gives the percent of total refinery energy allocated to the total refinery product production.

4. Emissions are allocated based on the percent of total refinery energy allocated to the total refinery product production (from step 3 above).

\section{CAPITAL EQUIPMENT}

Life cycle environmental flows associated with the production of the capital equipment and facilities used in the extraction, transportation and refining of crude oil are excluded from the fuel model since the energy used in the construction of large energy facilities and other equipment used in fuel cycles (including electric power plants, oil wells, oil tankers and hydroelectric plants) is negligible (less than 1\%) compared with the energy produced or carried by that equipment over its useful life ${ }^{29}$ (DeLuchi, 1993).

\footnotetext{
${ }^{26}$ Defense Mapping Agency, Hydrographic/Topographic Center, Distance Between Ports, Fifth edition, Publication 151, Washington, D.C. (1995)

${ }^{27}$ EIA, May 1995, Petroleum Supply Annual 1994 Volume 1.

${ }^{28}$ Environmental Protection Agency, July 1995. AP-42 Emission Factors.

${ }^{29}$ DeLuchi, M.A., 1993. Emissions of Greenhouse Gases from the Use of Transportation Fuels and Electricity.
} 
Production of electricity from heavy fuel oil includes heavy fuel oil pre-combustion, transportation of the heavy fuel oil to the utility and heavy fuel oil combustion (including control technologies). Data on heavy fuel oil pre-combustion is listed separately, therefore, this section only describes the heavy fuel oil transport and combustion.

\section{Transportation of Heavy Fuel OIL From Refinery to POWER Plant}

The transportation of heavy fuel oil from the refinery to a utility plant is assumed to be through the use of pipelines and road transport.

Of all the heavy fuel oil transported, $85 \%$ is assumed to be transported by pipeline an average distance of 800 miles. The remaining $15 \%$ is assumed to be transported by diesel truck an average (one-way distance of 75 miles $^{30}$.

Emissions from the two different types of transportation methods are included in the model. The emission factors for the different transportation methods are shown elsewhere.

\section{HeAvy Fuel OIL COMBustion}

The major source of data for the combustion of fuel oil is EPA AP42. As described in detail for the coal combustion, different technologies of fuel combustion have been averaged, according to their relative weight on the market.

Lime and limestone, used for flue gas desulfurization (FDG), are modeled. The average heavy fuel oil utility plants use different methods for scrubbing, such as limestone slurries and dry spraying, and use as the primary FGD materials lime and limestone. The quantities of lime and limestone needed are based on, the molar ratio needed to scrub the SOx, and the percentage of SOx (by weight) in the heavy fuel oil ${ }^{31}$. About 1.01 moles of FDG material are used to scrub 1 mole of $\mathrm{SO}_{2}{ }^{32}$.

${ }^{30}$ DeLuchi, M.A., 1993. Emissions of Greenhouse Gases from the Use of Transportation Fuels and Electricity, Volume 2: Table Ela and Appendix H (specifically, EIA Petroleum Supply Annual data).

${ }^{31}$ EPA, July 1995 . AP-42 air emissions factors.

32 Source at coal utility plant. 
Natural gas pre-combustion includes extraction of natural gas from the ground, then processing of the natural gas for use. Transportation to the point of use is not included at this stage.

\section{NATURAL GAS EXTRACTION}

Raw natural gas is a mixture of hydrocarbons, $\mathrm{N}_{2}, \mathrm{CO}_{2}$, sulfur compounds, and water. It may have any range of compounds from mostly methane to inert gases, such as nitrogen, carbon dioxide, and helium, and smaller amounts of ethane, propane, and butane. Natural gas may be mined onshore, offshore, and in conjunction with petroleum processes.

The energy used to mine natural gas is provided by EIA Natural Gas Annual ${ }^{33}$ and U.S. Bureau of Census ${ }^{34}$. The process energy is apportioned out among petroleum, natural gas, and natural gas liquids based on the following assumptions:

- Almost all the of natural gas consumed that the Census Bureau reports goes toward field operationsnatural gas lifting and reinjecting. This data correspond with data provided by EIA;

- Any energy used to reinject natural gas into wells is excluded from the natural gas pre-combustion processes, since reinjection is mainly used in oil wells; and

- The amount of electricity used for field equipment and processing plants is little relative to the amount of gas they produce ${ }^{35}$.

Thus, energy in this model excludes gas reinjection energy requirements.

\section{Natural Gas Processing (SWeetening)}

The amine process, or gas sweetening removes and recovers $\mathrm{H}_{2} \mathrm{~S}$. The recovered hydrogen sulfide gas is either (1) vented, (2) flared in waste gas flares or modern smokeless flares, (3) incinerated, or (4) utilized for the production of elemental sulfur or sulfuric acid. Emissions due to only venting the gas into the environment are covered in the model. Vented gas is usually passed to a tail gas incinerator in which the $\mathrm{H}_{2} \mathrm{~S}$ is oxidized to $\mathrm{SO}_{2}$ and is then passed to the atmosphere out a stack. Emissions are mostly $\mathrm{SO}_{2}$ due to the $100 \%$ conversion of $\mathrm{H}_{2} \mathrm{~S}$ to $\mathrm{SO}_{2}$. Very little particulate and $\mathrm{NOx}$ emissions are generated from this process. Emissions factors for the amine process come from AP-42 (1995).

${ }^{33}$ EIA, 1990. Natural Gas Annual 1989, Volume 1.

${ }^{34}$ US Department of Commerce, 1990. Census of Mineral Industries, Fuels, and Electrical Energy Consumed.

${ }^{35}$ DeLuchi, M.A., 1993. Emissions of Greenhouse Gases from the Use of Transportation Fuels and Electricity, Volume 2. 


\section{Natural Gas Electricity Production}

Production of electricity from natural gas includes natural gas pre-combustion, transportation of the natural gas to the utility, and natural gas combustion. Data on natural gas pre-combustion is listed separately, therefore, this section only describes the natural gas transport, and combustion.

\section{Transportation Of Natural Gas from StTE OF EXTRaCtion to POWER Plant}

Natural gas is transported by way of high-pressure transmission lines. Compressors along these lines may be powered from different sources: gas-fueled reciprocating engines and gas turbines, and electric motors. Emissions are all different due to the different sources of power in the compressors: the turbines, the engines, and the electric motors, so all of these sources will be modeled.

The total amount of gas that is consumed in the compressors is averaged over the different sources of power. It is known, however, that most pipeline compressor units are reciprocating engines, since reciprocating engines are more efficient when they operate under a large load. And since many of the compressors do operate under a large load, it may be assumed that there are more reciprocating engines in the compressors than turbines (DeLuchi, 1993). To obtain a breakdown of energy sources for compressors in transmission pipelines, actual pipeline company data was used. Averaging out the percent horsepower for each type of power source for the pipeline, it was found that:

\section{\% Horsepower in $1989^{36}$ :}

\begin{tabular}{|l|l|}
\hline Turbines: & $24.2 \%$ \\
\hline Engines: & $73.4 \%$ \\
\hline Electric: & $2.5 \%$ \\
\hline
\end{tabular}

Horsepower hours by type of compressor and the associated fuel combustion per horsepower-hour is used to obtain a weighted percent of energy and emissions due to each type of compressor in transmission pipelines. Since electric power is so little relative to the other compressors (2.5\%), it is neglected.

AP-42 (1995) provides emissions data for gas turbines and reciprocating engines. Emission factors for controlled (i.e., with NOx reduction technologies in place) for NOx, CO, TOC, total non-methane organic compounds, CH4, and PM-10. The control technology is assumed to be in place due to increasingly stricter NOx control standards. For gas turbines, uncontrolled emissions factors are provided for NOx, CO, TOC, total non-methane organic compounds, CH4, and PM-10 in AP-42 (1995).

\section{NATURAL Gas COMBUStion}

Natural gas is combusted in gas boilers. Emissions from combustion of natural gas are mainly due to improper operating conditions, such as inefficient mixing of fuel and air in the boiler, or an insufficient amount of air, etc. Emissions vary by the type and size of combustor and operating conditions.

Emissions factors for gas boilers were obtained from EPA AP-42 (1995) for NOx, CO, SOx, particulate matter, $\mathrm{CO}$, and TOC's. NOx control technologies are required for many boilers to comply with strict NOx emissions standards, so it is assumed that most boilers have NOx control technologies. Therefore, emissions factors for NOx in AP-42 (1995) use the factors for boilers with NOx control technologies.

${ }^{36}$ DeLuchi, Emissions of Greenhouse Gases from the Use of Transportation Fuels and Electricity, Volume 2:, Appendix G. 
Uranium contains two different isotopes, of uranium-238U and 235U. 235U is used as a fuel for nuclear reactors because it is fissionable, so the atoms can be split, releasing large amounts of heat. However, natural uranium consists of more than 99 percent $238 \mathrm{U}$ and less than 1 percent $235 \mathrm{U}$. To be used as a fuel, its $235 \mathrm{U}$ content must be enriched to 3-5 percent.

The data included in the model is uranium hexafluoride (UF6) manufacturing, enrichment of $235 \mathrm{U}$, and fuel rods manufacturing ${ }^{37}$. There is no available data on disposal of waste, plant construction, or emissions of radionucleides.

\footnotetext{
${ }^{37}$ Swiss Federal Office of Environment, Forests and Landscape (FOEFL or BUWAL). Environmental Series No. 132. p A15. Berne, February 1991, and E.E. El-Hinnawi: Environmental Impacts of Production and Use of Energy. Tycooli International 1981.
} 
Hydroelectric power generation refers to water used to generate electricity at plants in which turbine generators are driven by falling water.

Included in the hydroelectric power production model are greenhouse gas emissions $\left(\mathrm{CO}_{2}\right.$ and $\left.\mathrm{CH}_{4}\right)$ from operation of a hydroelectric plant (flooded biomass decomposition). The Federal Energy Regulatory Commission38 provides US hydroelectric plant information such as average annual generation, plant capacity, and reservoir area and depth.

Construction of the facility (steel and concrete production and transportation to the reservoir plus construction energy) is excluded from the model. Capital equipment in hydroelectric power production has been raised to be a potential source of burdens for hydroelectricity ${ }^{39}$ (it has been shown that capital equipment was negligible for fossil fuel combustion). However, in order to be consistent with the other energy production methods, capital equipment is excluded.

The data obtained on greenhouse gases emissions does not distinguish flooded biomass decomposition from new biomass decomposition and is assumed to refer only to flooded biomass.

${ }^{38}$ FERC database, 1996.

${ }^{39}$ Data from Chamberland, Andre and Levesque, S. Hydroelectricity, an Option to Reduce Greenhouse Gas Emissions from Thermal Power Plants. Energy Cons. Mgmt Vol. 37, Nos. 6-8, pp. 885-890. Chamberland's life cycle study is based on a group of facilities in northern Canada whose average lifespan is 100 years and produces annually $62,200 \mathrm{GWh}$ of electricity. 


\section{COMBUSTION EMISSIONS}

This section lists the emission factors for the following fuel combustion modules:

- Natural Gas Industrial Boilers (> $10010^{6} \mathrm{Btu} / \mathrm{hr}$ heat input)

- Heavy Fuel Oil Industrial Boilers

- Coal Industrial Boilers

- Diesel Industrial Engines

- Gasoline Industrial Engines

Most of the emission factors were obtained from the EPA document, "Compilation Of Air Pollutant Emission Factors", Volume I, Fifth Edition, Point Sources AP-42 (1995). These numbers were compared with a project done by Argonne National Laboratory ${ }^{40}$, to verify and expand on the EPA emission factors.

All the factors reported are for uncontrolled emissions. If control technologies are used, the emission factors should be reduced by the efficiencies of the control devices.

41) Wang, M.Q., GREET 1.0 - Transportation Fuel Cycles Model: Methodology and Use, Center for Transportation Research, Energy Systems Division, Argonne National Laboratory, Argonne, Illinois. 


\section{Diesel Barge:}

The barge was assumed to be a ship transporting generic goods, with a Btu/tonmile of 402 (source Emissions of Greenhouse Gases from the Use of Transportation Fuels and Electricity, M. DeLuchi)

Emission factors for $\mathrm{CO}, \mathrm{NOx}$ and $\mathrm{HC}$ are for a $2500 \mathrm{hp}$ diesel engine cruising speed (source - AP-42, US EPA). The deadweight tons for the ship are assumed to be under 15,000 .

The diesel fuel consumed is assumed to have $0.2 \%$ sulfur, converted completely to $\mathrm{SO}_{2}$ during combustion. The fuel density for the diesel fuel is assumed to be 3173.83 grams/gallon (source-Ecobalance of Packaging Materials State of 1990 , BUWAL)

\section{Diesel Truck:}

The truck is assumed to be an 18-ton heavy-duty truck, fully loaded; 5.5 miles/gallon is assumed. The emission factors are for 1991-1997 trucks operated at low altitude (source - AP-42, US EPA). $\mathrm{CO}_{2}$ and SOx emissions are calculated using the diesel fuel's carbon content and sulfur content respectively. Diesel fuel is assumed to be $0.2 \%$ sulfur and $85.8 \%$ carbon.

\section{Diesel Train:}

Data for average annual freight ton miles and gallons of diesel fuel consumed come from the Bureau of Transportation Statistics. The values are an average of six years worth of data (1990-1995).

Emission factors are for Class I railroads (source - Procedures for Emission Inventory Preparation - Vol. IV: Mobile Sources, Bureau of Transportation Statistics).

$\mathrm{CO}_{2}$ emissions are calculated using the assumption of $85.8 \%$ carbon in diesel fuel. Diesel fuel density is given as 3173.83 grams/gallon (source -Ecobalance of Packaging Materials State of 1990, BUWAL).

\section{Heavy Fuel Oil Ocean Tanker:}

The tanker is assumed to be an international oil tanker averaged over different deadweight ton sizes, transporting crude oil or petroleum products. The fuel oil density is given as 3575 grams/gallon and the btu/ton mile is calculated as 114 (source-Emissions of Greenhouse Gases from the Use of Transportation Fuels and Electricity, M. DeLuchi).

$\mathrm{CO}_{2}$ and SOx emissions are calculated using the heavy fuel oil's carbon content and sulfur content respectively. Heavy fuel oil is assumed to be $2.2 \%$ sulfur and $85.8 \%$ carbon.

Emissions are calculated using general fuel oil tanker emission in grams $/ 10^{6}$ btu of fuel (source-Emissions of Greenhouse Gases from the Use of Transportation Fuels and Electricity, M. DeLuchi) 


\section{ELECTRICITY PRODUCTION PER GEOGRAPHICAL ZONE}

The following tables show the electricity production percentages for the different North American Electric Reliability Council (NERC) regions in the North America ${ }^{41}$.

\begin{tabular}{|c|c|c|c|c|c|}
\hline \multirow[b]{2}{*}{ Fuel Type } & \multicolumn{5}{|c|}{ NERC Region } \\
\hline & NPCC & $E C A R$ & WSCC & ERCOT & SERC \\
\hline HFO & $10.7 \%$ & $0.3 \%$ & $0.1 \%$ & $0.1 \%$ & $3.4 \%$ \\
\hline Hydro & $15.4 \%$ & $0.5 \%$ & $40.6 \%$ & $0.3 \%$ & $4.6 \%$ \\
\hline NG & $18.3 \%$ & $0.5 \%$ & $10.2 \%$ & $37.4 \%$ & $5.9 \%$ \\
\hline Nuclear & $35.1 \%$ & $10.4 \%$ & $12.8 \%$ & $17.1 \%$ & $29.5 \%$ \\
\hline Coal & $20.5 \%$ & $88.3 \%$ & $36.3 \%$ & $45.2 \%$ & $56.6 \%$ \\
\hline Fuel Type & $M A A C$ & $M A P P$ & $\begin{array}{l}\text { RC Regi } \\
\text { MAIN }\end{array}$ & $S P P$ & US Average \\
\hline HFO & $3.1 \%$ & $0.5 \%$ & $0.5 \%$ & $0.3 \%$ & $2 \%$ \\
\hline Hydro & $0.8 \%$ & $8.4 \%$ & $1.4 \%$ & $2.9 \%$ & $9.8 \%$ \\
\hline NG & $5.3 \%$ & $0.9 \%$ & $1.7 \%$ & $28.3 \%$ & $10.2 \%$ \\
\hline Nuclear & $40.8 \%$ & $15.9 \%$ & $42.4 \%$ & $15.7 \%$ & $23 \%$ \\
\hline Coal & $50 \%$ & $74.3 \%$ & $54 \%$ & $52.8 \%$ & $55 \%$ \\
\hline
\end{tabular}

Note that the percentages are given for the United States portion of the region listed. Some regions are split between Canada and the United States (WSCC for example), however, the electricity production percentages are given for only the United States portion.

The different NERC regions are described on the figure below.

${ }^{41}$ Electricity source percentages from: EIA-759, U.S. Department of Energy, 1995 Electric Utility Net Generation by NERC Region and Fuel Type. 


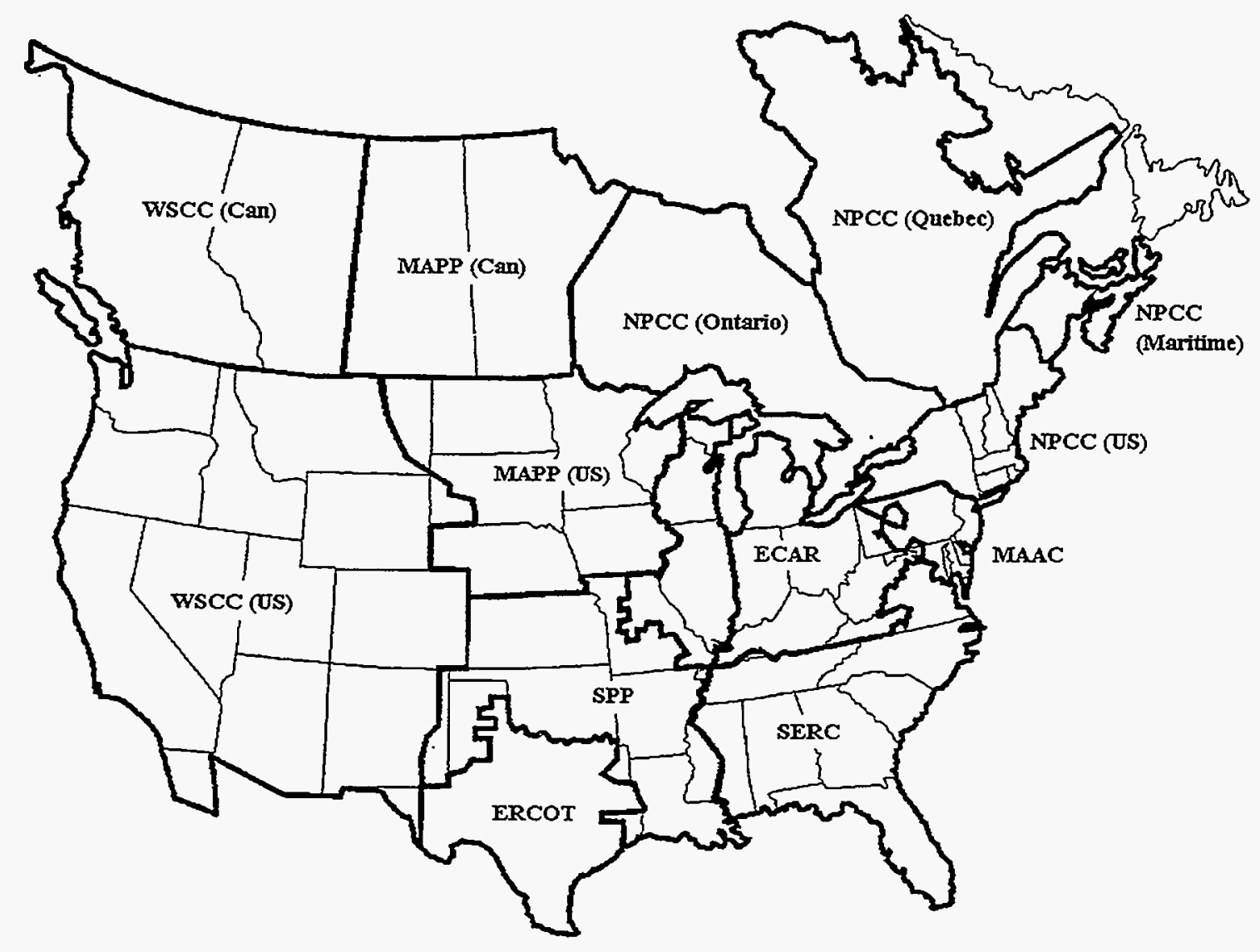

Map of the NERC regions in the United States and in Canada 


\section{LIMESTONE PRODUCTION}

Production of limestone includes quarrying of the limestone. Transportation of the limestone to the point of use is not included at this stage.

Limestone quarrying is modeled as diesel fuel, natural gas and electricity use. The amount of fuel and electricity used is based on Swiss Federal Office of Environment, Forests and Landscape (FOEFL or BUWAL) data ${ }^{2 !}$.

Diesel fuel, natural gas and electricity production are based on Ecobalance's energy carrier LCI data.

Diesel fuel combustion emissions are based on United States Environmental Protection Agency (US EPA) data. The AP- 42 mobile source emissions factors for miscellaneous heavy duty construction equipment are used to model the emissions form the combustion of the diesel fuel used in limestone quarrying.

Natural gas combustion emissions are based on Ecobalance's energy carrier LCI data for combustion of natural gas in an industrial boiler and in industrial engines ${ }^{22}$. It is assumed that $50 \%$ of the natural gas used is combusted in an industrial boiler and $50 \%$ is combusted in an industrial engine.

Other LCI flows from limestone quarrying include solid waste production, and particulate emissions from quarrying operations. These additional LCI flows are also based on Swiss Federal Office of Environment, Forests and Landscape (FOEFL or BUWAL) data ${ }^{23}$.

Water effluents coming from limestone quarrying are considered negligible for this study. In general, the only water effluents coming from limestone production are those from mining (and refining) the fuels and producing the electricity that are used to quarry the limestone.

\footnotetext{
${ }^{21}$ Environmental Series No. 132, Bern, February 1991. energy requirements page A35

22 Based on US EPA AP-42 data.

${ }^{23}$ Environmental Series No. 132, Bern, February 1991. air/water/waste page A36
} 


\section{REPORT DOCUMENTATION PAGE}

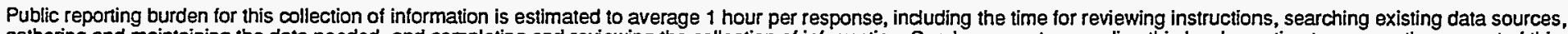

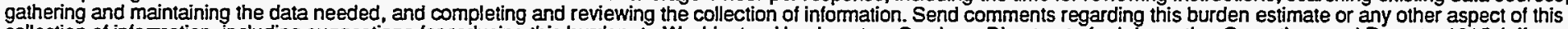

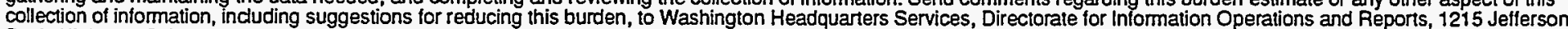

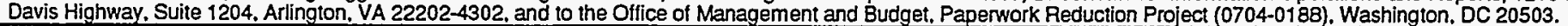

1. AGENCY USE ONLY (Leave blank)

\section{REPORT TYPE AND DATES COVERED}

Technical Report

\section{TITLE AND SUBTITLE}

December 1997

Life Cycle Assessment of a Biomass Gasification Combined-Cycle System
6. AUTHOR(S)
M.K. Mann and P.L. Spath

\section{PERFORMING ORGANIZATION NAME(S) AND ADDRESS(ES)}

National Renewable Energy Laboratory

1617 Cole Boulevard

Golden, CO 80401-3393

9. SPONSORINGMONITORING AGENCY NAME(S) AND ADDRESS(ES)

National Renewable Energy Laboratory

1617 Cole Boulevard

Golden, CO 80401-3393

\section{SUPPLEMENTARY NOTES}

\section{2a. DISTRIBUTIONAVAILABILITY STATEMENT}

National Technical Information Service

U.S. Department of Commerce

5285 Port Royal Road

Springfield, VA 22161

13. ABSTRACT (Maximum 200 words) A life cycle assessmenton of a hypothetical biomass integrated combined cycle power plant in the Midwestern United States was conducted recently at the National Renewable Energy Laboratory. The plant's system consists of biomass production, its transportation to the power plant, electricity generation, and any upstream processes required to operate it. The purpose of the LCA was to determine the environmental advantages and disadvantages of producing electricity from biomass.

\section{SUBJECT TERMS}

biomass, life cycle assessment, dedicated feedstock
17. SECURITY CLASSIFICATION OF REPORT

\section{SECURITY CLASSIFICATION OF THIS PAGE}

15. NUMBER OF PAGES

159

16. PRICE CODE
8. PERFORMING ORGANIZATION REPORT NUMBER

10. SPONSORINGMONITORING AGENCY REPORT NUMBER

NRELTP-430-23076 12b. DISTRIBUTION CODE
Standard Form 298 (Rev. 2-89)

Prescribed by ANSI Std. Z39-18 